Columbia Law School

Scholarship Archive

1977

\title{
Beyond the Shut-Eyed Sentry: Toward a Theoretical View of Corporate Misconduct and an Effective Legal Response
}

John C. Coffee Jr.

Columbia Law School, jcoffee@law.columbia.edu

Follow this and additional works at: https://scholarship.law.columbia.edu/faculty_scholarship

Part of the Business Organizations Law Commons, Criminal Law Commons, and the Criminal Procedure Commons

\section{Recommended Citation}

John C. Coffee Jr., Beyond the Shut-Eyed Sentry: Toward a Theoretical View of Corporate Misconduct and an Effective Legal Response, 63 VA. L. REV. 1099 (1977).

Available at: https://scholarship.law.columbia.edu/faculty_scholarship/541

This Article is brought to you for free and open access by the Faculty Publications at Scholarship Archive. It has been accepted for inclusion in Faculty Scholarship by an authorized administrator of Scholarship Archive. For more information, please contact scholarshiparchive@law.columbia.edu. 


\section{VIRGINIA LAW REVIEW}

VOLUME 63

NOVEMBER 1977

NUMBER 7

BEYOND THE SHUT-EYED SENTRY: TOWARD A THEORETICAL VIEW OF CORPORATE MISCONDUCT AND AN EFFEGTIVE LEGAL RESPONSE

John C. Coffee, Jr. *

INTRODUCTION

I. Toward a Theoretical View: From Observation

to Model BuILding ................. 1115

A. A Quick Tour of Yesterday's Headlines ...... 1115

B. The Basic Patterns: An Arrangement in

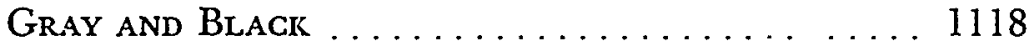

1. The "Aggressive" Payment . . . . . . . . 1118

2. The "Defensive" Payment . . . . . . . . 1119

3. The "Grease" Payment ............. 1120

4. Bribery by Proxy: Use of the Middleman . 1122

5. The "Legal" Politic.al Contribution... 1123

C. The Undefined Duties . . . . . . . . . . . . 1125

D. The Breakdown in Corporate Norms ....... 1127

1. The Dominance of Operations over Policy . . . . . . . . . . . . . . . 1129

2. The Imbalance Between the Board and the Ghief Executive Officer ........ 1130

3. The Problem of Information Blockages. 1131

E. An Overview of Internal Corporate Decisionmaking . . . . . . . . . . . . . . . 1132

F. A Proposed Model: The Mini-Board-Making Structure Follow Strategy ........... 1147

II. Toward a Legal View: Surveying the CoNTEMPORARY LEGAL TERRAIN . . . . . . . . . . . . 1156

- Associate Professor of Law, Georgetown University Law Center; B.A., Amherst College, I966; LL.B., Yale Law School, 1969. 
A. A Cook's Tour of Commercial. Bribery . . . . . 1157

B. The Plaintiff's Gase: Taking Inventory of the Theories Avallable .............. 1161

1. Theories of Strict Liability . . . . . . 1162

a. Negligence Per $\mathrm{Se} \ldots \ldots \ldots \ldots \ldots \ldots 1162$

b. Ultra Vires . . . . . . . . . . . 1166

c. ThE "Knowing Violation" ........ 1172

2. Negligence Theories . . . . . . . . . . . . 1183

3. The Public Policy Doctrine ......... 1190

4. A Preliminary Evaluation .......... 1197

C. Corporate Counsel Rebuts: A Survey of the

Defenses . . . . . . . . . . . . . . . . . . . 1199

1. The Defense of Reliance upon Counsel versus the "Duty to Disclose" . . . . . . . . 1199

2. The Duress Defense: The Corporation

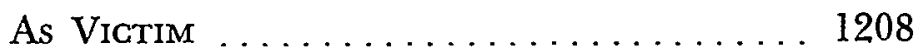

3. The Proximate Cause Defense and the Net Loss Rule . . . . . . . . . . . . . . . . . 1213

4. The Business Judgment Defense: But Who Will Guard the Guardians? ....... 1222

a. Procedural Limitations ............ 1229

b. Substantive Limitations . . . . . . . 1237

D. Summary . . . . . . . . . . . . . . . . . . . 1241

III. The Feneral Securities Laws and Corporate

Misconduct: Does the SEC Have a BetTer IDEa? . . I 1246

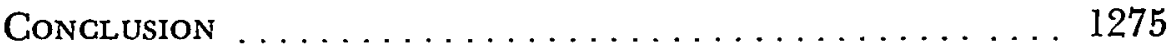

\section{INTRODUCTION}

T IKE hard cases, festering scandals make bad law. As public 1 perceptions shift so that conduct once tolerated becomes seen as illicit, political pressures develop that can result in hastily improvised responses by the legal system to fill the newly perceived vacuum. This generalization is advanced to question neither the inalienable right of the public to be scandalized, nor the need for corporate reform, but to approach a highly problematic dilemma: hurried, moralistic responses to a perceived evil often prove not only ineffective, but even counterproductive. The serious student of complex organizations may recognize this assertion as a slightly altered variant of Forrester's Law. That law, coined by a student 
of organizational behavior, says simply that complex systems behave counter-intuitively; the plausible tends to be wrong. ${ }^{1}$

Percolating throughout this article will be the theme of an inherent conflict between "moralistic" legal responses, which seek to maximize the public reprobation and symbolic denunciation of the conduct in question, and "pragmatic" legal responses, which focus instead on prevention and therefore seek to optimize whatever conditions within the system most inhibit the disapproved conduct. Closely linked and often overlapping with this theme will be another recurrent one: the differing effectiveness of positive and negative incentives in changing behavior within the corporation's own social system. The relevance of these themes will become clearer as we turn to the familiar topic of corporate misconduct, with particular emphasis on questionable payments. For the past four years, the business pages of American newspapers have carried a continuing story of corporate misconduct with the same daily regularity as the sports pages have reprinted the baseball box

1 See J. Forrester, World Dynamics (1971); J. Forrester, Urban Dynamics (1969). For an incisive application of Professor Forrester's concepts to the context of the corporation, see P. Drucker, Management: Tasks, Responsibilities, Practices 507-11 (1973) [hereinafter cited as P. DRUCKER]. Professor Conard's provocative comments on the divergence between "idealistic" and "realistic" models of behavior for directors also suggest the continuing relevance of Forrester's Law in this area. See Conard, A Behavioral Analysis of Director's Liability for Negligence, 1972 Duke L.J. 895.

Because the basic argument of this article is that the corporation must be understood as a bureaucracy and can only be effectively regulated once the realities of behavior within large organizations are understood, it seems useful to collect at the outset some of the principal works of the organization theorists who have attempted to describe those realities. In addition to P. Drucker, supra, a basic list includes C. ARGYris, INTEGRATING The INDIvidual and the Organization (1964); G. Dalton, L. Barnes, \& A. Zaleznik, The Distribution of Authortty in Formal Organizations (1968); A. Downs, Inside Bureaucracy (1966); P. Drucker, The Concept of the Corporation (2d ed. 1972); J. Emery, Organizational Planning and Control Systems (1969); R. Likert, The Human Organization (1967); J. March \& H. Simon, Organizations (1958); W. Morris, Decentralization in Management Systems (1968); G. Tullock, The Polttics of Bureaucracy (1965); O. Williamison, Markets and Hierarchies (1975); O. Williamson, Corporate Control and Business Bemavior (1970) [hereinafter cited as Corporate Control]; The Corporate Society (R. Martis ed. 1974); Modern Organization Theory (M. Haire ed. 1959) (containing probably the broadest spectrum of organizational perspectives and with P. DRUCKER, supra, the best introduction). See also Note, Decisionmaking Models and the Control of Corporate Crime, 85 YALE L.J. 1091 (1976).

On a more popular level, M. Maccoby, The Gamesman: The New Corporate Leaders (1976), and J.K. Galbraith, The New Industrial State (1967) share at times a similar perspective with the foregoing theorists (though each may be accused of tunnel vision). For a short but sophisticated analysis of Galbraith's idea of the "technostructure" as it applies to corporate behavior, see Marris, Galbraith, Solow, and the Truth about Corporations, II Pub. INTEREST 37 (1968). 
scores. ${ }^{2}$ It appears that commercial bribery has been a competitive technique as important for some corporations as price or product competition. ${ }^{3}$ To date, well over 350 public corporations, ${ }^{4}$ includ-

2 Because our focus will be on the internal dynamics of the corporation, and not the socio-political environment surrounding it, this article will not attempt to summarize in detail the tidal wave of disclosures that the improper payments controversy has elicited or the ensuing reaction by courts, Congress, and administrative agencies. The most important official study in this area is still Senate Banking, Housing, AND URban Affairs Comm., 94th Cong., 2D Sess., Report of the Securities and Exchange Commission on Questionable and Illegal Corporate Payments and Practices (Comm. Print 1976) [hereinafter cited as SEC PAYMents Report]. But see also Staff of Subcomm. on Oversight and Investigations of the House Comm. on Interstate and Foreign Commerce, 94th Conc., 2p Sess., SEC Voluntary Complance Program on Corporate Disclosure (Subcomm. Print 1976) (criticizing SEC PAYMIENTs REPORT, supra, and studying certain of its case examples in more detail). The final report of that subcommittee contains one of the most thoroughgoing attempts by a governmental body to rethink the problem of corporate accountability in light of the improper payments controversy. See SubComm. on Oversight aNd INVESTIGAtions of the House Comm. on Interstate and Foreign Commerce, 94th Cong., 2d Sess., Federal Regulation and Regulatory Reform 33-42, 51 -53 (Subcomm. Print 1976).

The most comprehensive survey of recent legal developments is Herliny \& Levine, Corporate Crisis: The Overseas Payment Problem, 8 L. \&: Pol'y INT'L Bus. 547 (1976). (the authors are both attorneys in the SEC's Division of Enforcement). See also Brownlee \& Queenan, Questionable Corporate Payments: Dealing with Fluid, Uncertain Factors, in N.Y.L.J. Special Report: SEC 77, 176 N.Y.L.J. No. 112, Dec. 13, 1976, at 27; Kohlmeier, The Bribe Busters, N.Y. Times, Sept. 26, 1976, $\$ 6$ (Magazine), at 47; Stevenson, The SEC and Foreign Bribery, 32 Bus. LAw. 53 (1976); The Corporate Rush to Confess All, Bus. WeEk, Feb. 23, 1976, at 22; The Big Payoff, TrMe, Feb. 23, 1976, at 28.

From the special standpoint of this article, the following articles provide insights into the internal corporate decisionmaking process underlying the crisis: Faber, How I Lost Our Great Debate About Corporate Ethics, ForTune, November, 1976, at 180; Guzzardi, An Unscandalized View of Those "Bribes" Abroad, ForTune, July, 1976, at 118; Gwirtzman, Is Bribery Defensible?, N.Y. Times, Oct. 5, 1975, $\$ 6$ (Magazine), at 19; Hougan, The Business of Buying Friends, HARPER's, December, 1976, at 43; Robertson, The Directors Woke UP Too Late at Gulf, ForTune, June, 1976, at 121; Sampson, Why Arms Merchants Have to Pay Off Adnan Khashoggi, NEw YoRK, Apr. 15, 1976, at 44; Tracy, How United Brands Survived the Banana War, ForTunE, July, 1976, at 145.

3 The controversy has spawned a new literary genre: the post-mortem corporate self study. It usually is prepared by a special committee of the board and provided to stockholders, generally as a precondition for the settlement of an SEC civil action. The following two reports are well known within the securities industry and are instructive in their diagnoses:

(a) Board of Directors of Gulf Oil Corp., Report of the Special Review Committee of THE Board of Directors of Gulf OIL Corporatton (Dec. 30, 1975) (This report, which is popularly known as the "McCloy Report" after its chairman, John J. McCloy, has been published in paperback as J. McCloy, ThE Great OIL SpILl (1976) [hereinafter cited as J. McCloy];

(b) Board of Directors of Exxon Corp., Determination and Report of the Special Committee on Litigation (Jan. 23, 1976) [hereinafter cited as Exxon Report].

4 SEC's Program for Voluntary Disclosure of Questionable Payments May End Soon, Wall St. J., Mar. 7, 1977, at 4, col. 2. Also, the SEC has brought over 30 civil actions 
ing such flagships of our free enterprise system as Exxon, Gulf, and even General Motors, have acknowledged payments ranging from de minimis amounts to nearly $\$ 60$ million, ${ }^{5}$ and aggregating in excess of an estimated $\$ 300$ million. ${ }^{6}$ In addition, governments have been toppled, prime ministers and generals jailed, dictators deposed, and a monarchy threatened. ${ }^{7}$

More important than the corrupt activities uncovered, however, is the recurring dysfunction within the organizational structure of the corporation itself that these disclosures have revealed. Part of this dysfunction involves a recurring management style-overzealous, action-oriented, and characterized by a remarkably low level of risk aversion. ${ }^{8}$ Although the dominance of such a style may not be startling, given the rough and tumble world out of which

against companies not participating in the program. Id. For a partial list of these civil actions, see Herlihy \& Levine, supra note 2, at $580 \mathrm{n} .188$.

5 For the "nearly $\$ 60$ million" estimate, see Political Slush Fund Hid Other Spending, Cost Exxon Millions, Wall St. J., Nov. 14, 1975, at 1, col. 6. See also Gall v. Exxon Corp., 418 F. Supp. 508, 509 (S.D.N.Y. 1976) (placing the number at $\$ 59$ million).

6 This estimate has been made by the Council on Economic Priorities. See Hershey, Payoffs: Are They Stopped or Just Better Hidden?, N.Y. Times, Jan. 9, 1977, $\$ 3$ (National Economic Survey), at 23. Although Exxon's $\$ 59$ million in payments makes it the unchallenged leader, a number of other corporations appear to have played in the same league, despite much lower revenues and earnings. For example, Lockheed's recently issued report (which itself cost $\$ 4$ million) placed the total questionable payments made by that corporation between 1970 and 1975 as high as $\$ 38$ million. Lockheed Puts Foreign Payoffs Near $\$ 38$ Million, Wall St. J., May 27, 1977, at 4, col. 2. Estimates have placed the questionable commission payments that Northrop and Grumman contracted to make in connection with individual arms sales contracts as high as $\$ 45$ million and $\$ 28$ million, respectively. See The Big Payoff, supra note 2, at 33. See also SEC PAymenrs RePorT, supra note 2, at 13-17. Gulf has acknowledged spending over \$12 million. See J. McCloy, supra note 3 , at 2 .

7 See generally The Big Payoff, supra note 2, at 34-36; Damage to Governments Friendly to U.S. Is Seen in Disclosure of Lockheed Bribes, Wall St. J., Feb. 9, 1976, at 7, col. 1. The falls of the Tanaka government in Japan, the junta led by General Rene Barrientos in Bolivia, and the administration of President Arellano in Honduras all frequently have been attributed to the disclosures made respectively by Lockheed, Gulf, and United Brands. See, e.g., Italy Explores Banana Bribery, N.Y. Times, May 24, 1975, at 33, col. 1.

8 It seems more than coincidental that close observers have characterized the chief executive officers of three of the corporations most prominent in the improper payments controversy (Northrop, United Brands, and Gulf) as strong-willed, imperious men who totally dominated, and seldom confided in or relied upon, their boards of directors. See Clearing Payoff Storm, Northrop Chief Keeps Firm Hand on Controls, Wall St. J., Dec. 15, 1976, at 1, col. 6; As the Storm Abates, United Brands Seeks to Turn Itself Around, Wall St. J., Oct. 14, 1976, at 1, col. 6; Robertson, supra note 2, at 209 (Gulf). On a more generalized level, these descriptions seem to fit one of the typologies offered by Maccoby to characterize the modern business executive: that of the jungle fighter and empire builder. See M. MAccoBY, supra note 1, at 76-85. See also note 101 infra. 
corporate managers emerge, the surprising discovery is the apparent absence of any countervailing system of internal checks and balances within the corporation. ${ }^{9}$

The revelations emerging from the "improper" payments controversy do not stand alone. Other recently newsworthy corporate misdeeds-such as participation in the Arab boycott of Israel, violations of the Bank Secrecy Act, large-scale substitution of allegedly inferior automobile engines, alleged diversions of natural gas supplies, and a host of garden variety antitrust and tax law violations ${ }^{10}$-also share certain distinguishing features in common with improper payments. First, the conduct typically has involved at worst a regulatory offense ("malum prohibitum" rather than "malum in se"). Second, the current state of the law generally has been sufficiently uncertain that a corporate official, usually at some

9 On the general absence of such a countervailing system today, see C. Brown, Purting THE CORPORATE BOARD TO WORK 15-21 (1976).

10 Again, a complete litany of every allegation recently levied at corporations is neither possible nor useful. But the following is a representative sample:

(1) The recent conviction of the nation's sixth largest bank on 445 misdemeanor counts of "laundering" funds for narcotics dealers. See Chemical Bank Cited for Failure to List Big Cash Exchanges, N.Y. Times, Feb. 25, 1977, at 1, col. 1; Chemical Bank Fined $\$ 225,500$ in Misdemeanors, Wall St. J., Apr. 15, 1977, at 8, col. 3. Similar "laundering operations" appear to have been conducted at other major New York banks. Other N.Y. Banks Studied for Laundering Operations, Wash. Post, Feb. 26, 1977, at C9, col. 5;

(2) The acknowledged sale by General Motors of 43,000 Oldsmobiles containing Chevrolet engines. G.M. Sued on Switched Engines; Illinois Asks Restitution to Buyer, N.Y. Times, Mar. 8, 1977, at 41 , col. 4;

(3) The tacit participation of American banks in the Arab boycott of Israel through enforcement of anti-Israeli terms in commercial letters of credit. Allan, The Arab Boycott and the Banks, N.Y. Times, Sept. 12, 1976, $\$ 3$ (Business and Finance), at 9 , col. 1;

(4) The improper diversion by Tenneco of natural gas contracted to interstate customers in order to sell it at a higher price in the intrastate market. Tenneco Admits Improper Shifts of Natural Gas, N.Y. Times, Mar. 8, 1977, at 1, col. 5; and (5) The much-publicized conviction of Allied Chemical for permitting Kepone to be dumped in the James River. Following its conviction and a record fine, Allied Chemical entered into a consent agreement with the SEC under which its senior management agreed to install new controls and warning devices to alert it to misconduct by lower-echelon corporate officials. Chemical Firm Bows to SEC Over Kepone, Wash. Post, Mar. 5, 1977, at A-11, col. 3. For further discussion of this case, see text accompanying notes 605-07 infra.

In all of these cases, a common denominator seems to have been that the locus of the misconduct apparently was at a level well below that of senior management. 
lower level within the corporate hierarchy, ${ }^{11}$ felt the risk of illegality to be acceptable. Finally, and most importantly, corporate officials have engaged in these various forms of misconduct to benefit, not to injure, the corporation.

This last point is particularly significant, because such "benevolent" misconduct vastly differs from the type of misconduct on which modern corporate law commentators have principally focused: misconduct arising out of conflicts of interest between management and its stockholders. ${ }^{12}$ When the action is undertaken to maximize corporate profits, one can only perceive a conflict, rather than an identity, of interests between these two groups by moving to a higher level of abstraction and postulating a difference either between the levels of risk aversion that characterize management and its stockholders or between the time frames in which they wish to maximize profits. ${ }^{13}$ Although there may exist

11 The SEC Payments Report suggests that corporate misconduct typically occurs at a much lower level within the corporate hierarchy than the senior executive suite. While in some cases the chief executive's office did direct the payments program (e.g., Gulf, Lockheed, United Brands, and Northrop), this pattern typifies only the minority of the cases. Of the first 89 cases studied by the SEC, top management had knowledge in only 40 cases (or $47 \%$ ). See SEC PAyments Report, supra note 2, at 41 . Similarly, a survey by the House Subcommittee on Oversight and Investigations found a $40 \%$ figure to characterize the $\mathbf{2 5}$ additional companies they investigated. See Federal Regulation and ReguLATORY REFORM, supra note 2 , at 33.

12 The discovery of a deep-rooted conflict between management and stockholders, and a tipping of the balance of power to the former, was the major and original perception of Berle and Means. See A. Berle \& G. Means, The Modern Corporation and Private ProperTy (1932). Because of the separation between ownership and control, Berle and Means questioned the assumption that management operated in the interests of shareholders. Id. at 121. This same perception seems to supply the starting point for Professor Eisenberg's recent heroic attempt to suggest a new legal model for the corporation, which would enhance the shareholder's powers and capabilities. See M. EIsEnbERG, ThE STRUCTURE OF THE CoRPORATION (1976). For another interesting attempt in the same vein, see Anderson, Toward a Theory of Conflicts of Interest: Efficiency, Fairness and Corporate Structure, 25 U.C.L.A. L. REv. - (1978). Without challenging the importance or accuracy of the theme of conflict, this article will suggest that, in light of modern organization theory, the problem of "control loss" within the large decentralized corporation may deserve a higher priority in our thinking than problems of conflict of interest.

13 In other words, to the extent that management is significantly less risk averse or more interested in short-run profit maximization (at the expense of long-term growth) than the majority of its investors, there again emerge unresolved conflicts of interests between fiduciary and beneficiary. There are a variety of reasons why such differences might exist. First, management's interest may be particularly focused on the short term, while the investor's is on the long term, because managerial performance is likely to be judged over the short term. See Bower, On the Amoral Organization, in The CorpoRATE SOCIETY, supra note 1, at 178, I91-92. Second, the reward structures for each are different. Management is interested typically in its salary and in incentive compensation such as 
considerable evidence to support such a hypothesis, it can be neither uniformly true (because corporate misconduct has not always carried a high level of risk) nor empirically verifiable in any given situation. In any event, we are left with the possibility that the proposals for new systems of corporate accountability that have been designed primarily to combat traditional conflicts of interest may not be well adapted to deal with this newer species of corporate misconduct, whose hallmark is managerial overzealousness.

As we identify a common pattern of managerial overzealousness behind these practices, fairness requires that we also acknowledge a partially countervailing perception. Examination of the specific factual contexts surrounding many improper payments evokes some sympathy for, and at times even a visceral sense of identification with, the corporate manager caught in a difficult dilemma between long-established local customs of extortion and our own more rigorous standards of corporate ethics. Whether this sympathetic reaction undermines deterrence to an unacceptable degree is debatable. But seemingly, if we could structure into a comprehensive legal response to corporate misconduct some safe harbor for the corporate manager trapped in such a situation, we would have struck a more desirable balance. Basic concepts of fairness argue for some limits on the degree to which corporate officials seeking to benefit (and perhaps actually benefitting) the corporation should be held liable in order to deter others.

An alleged final symptom of corporate dysfunction that has surfaced recently has involved an attitude on the part of those who should have been guarding the corporation against managerial

bonuses and stock options, which depend on performance in the short term, while the investor is more interested, in part for tax reasons, in long-term capital appreciation. Third, management has a defensive motivation for accepting risks that the investor would prefer to reject: it has to be concerned with short-run profit maximization because of the danger to it of hostile takeovers and tender offers.

A final empirically based reason for differences between investors and management in their attitudes towards risk is that the new corporate executive may simply enjoy taking risks, and also finds it a means of advancing his career within the corporation (at the possible expense of the corporation). M. MAccoBy, supra note I, at 48-49. Thus, risk taking for the manager can be both an aspect of careerism and a pleasurable private avocation, and unrelated to the investor's risk preferences. In this light, the implications of Maccoby's findings conflict particularly with Galbraith's view that the basic tendency of the technostructure is towards autonomy, security, and the elimination of competition in favor of a system of administered prices and stable, orderly growth. See J.K. GaLBRAITH, supra note $\mathrm{I}$. 
overzealousness, the corporate directors. This attitude has been described as resembling that of the "shut-eyed sentry" in Kipling's poem, who deliberately averts his glance in order to avoid witnessing misconduct. ${ }^{14}$ In fact, this theme of "directors who do not direct" ${ }^{15}$ has a long and popular history among commentators on corporate law. ${ }^{16}$ If the sentries have been derelict, the obvious answer would appear to be to court-martial them in order to deter others from sleeping at the guard post. Translated into legal terminology, such a prescription would ask us to revive, expand, and enforce the ancient and largely somnolent common-law rule that a director owes a duty of due care to his corporation. But this article will argue that such a prescription, standing alone, is unduly simplistic, because it is based on a fundamental misconception of where existing systems of corporate accountability have broken down.

At this point the conflict between a moralistic and a pragmatic response reappears to interfere with the simple progression from diagnosis to prescription. To begin with an obvious problem, increasing to a draconian level the potential liabilities of corporate officers and directors would be counterproductive, intimidating exactly that class of persons upon whom we will most likely depend to prevent corporate misconduct: potential "outside" directors. ${ }^{17}$

14 The McCloy Report coined this term. See J. McCloy, supra note 3, at 295. The quotation from Kipling reads: "But I'd shut my eyes in the sentry-box/So I didn't see nothin' wrong." Robertson, supra note 2, at 210.

15 Douglas, Directors Who Do Not Direct, 47 HARv. L. Rev. 1305 (1934).

16 This theme dates back at least to the turn of the century, see, e.g., Dwight, Liability of Corporate Directors, 17 YALE L.J. 33 (1907), and survives today, see, e.g., Bishop, Sitting Ducks and Decoy Ducks: New Trends in the Indemnification of Corporate Directors and Officers, 77 YALE L.J. 1078 (1968).

17 While previous predictions that independent directors would be driven off corporate boards by the threat of liability have proven premature, there is considerable evidence that the effect of several large settlements in recent shareholder suits plus the increasing unavailability of meaningful liability insurance may now be producing this result. The multimillion dollar settlement of the recent Gulf Oil shareholder suits is but one example. See Gulf Directors Approve Settlement Terms of Eight Shareholder Suits on Slush Fund, Wall St. J., Sept. 24, 1976, at 34, col. 2. See also Conard, supra note 1, at 899-903; Why Lawyers and Bankers Desert the Board, Bus. WEEK, Mar. 29, 1976, at 100.

One director of four companies recently estimated that he is a defendant in ten such lawsuits, and commented, "It worries the hell out of me. I feel like the Israelis-I can't afford to lose one." The Hot Seat: Outside Directors Get Tough After Payoff Scandals, Wall St. J., Mar. 24, 1976, at I6, col. 1. Particularly worrisome for the outside director is that standard officers' and directors' liability insurance policies, when available, now contain exclusionary clauses expressly directed at the payoff scandal. As Suits Rise, Firms 
But a more important objection is that although some directors undoubtedly have served as "decoys," or at least have been sleepyeyed sentries, there is no assurance that diligent directors would have performed much better. Paradoxically, there are even some indications that replacing the current club-like intimacy between the board and management with the adversarial atmosphere that would accompany diligent monitoring by a moralistic board probably would increase internal secrecy and reduce the flow of information to the board. ${ }^{18}$ Thus, at the risk of belaboring Forrester's Law, there is a need here to focus on the social system we wish to influence as a whole: the internal corporate hierarchy. Piecemeal changes may well produce unintended and counterproductive consequences.

Accordingly, what general goals are we seeking to realize? Because our preliminary diagnosis suggests that within what might be termed the psyche of the American corporation there is a fundamental imbalance between a strong ego and a weak superego, an intelligent prescription might seek to encourage the institutionalization of a stronger corporate superego. Phrased in the language of lawyers, this would mean the creation of a system of internal checks and balances by which to restrain managerial overzealousness. But how do we accomplish this? Do we even know what internal configurations of authority and communications within the corporation will maximize the deliberate and responsible decisionmaking that we desire?

Unfortunately, the short answer here is that corporate law currently lacks not only a solution to this problem, but even any criteria by which to evaluate the relative efficacy of competing proposed answers. To be sure, there has been no recent shortage of proposed solutions put forward by lawyers. ${ }^{19}$ But most of these

Scramble to Xncrease Insurance for Directors, Wall St. J., July 12, 1976, at 1, col. 6. The average payout under such policies rose from $\$ 770,000$ in 1974 to $\$ 865,000$ in 1975 . Estes, Outside Directors: More Vulnerable Than Ever, HARv. Bus. REv., January-February, 1973 , at 107 .

18 See text accompanying notes 163-68 infra.

19 In overview, recent proposals for structural change in the current status of the private corporation fall under one of four main headings:

(1) "Politicalization" of the Corporation. The most radical alternative, this approach would require the presence of various representatives of "public interest" groups on the corporate board. See, e.g., R. NAdER, M. GReEn, \& J. Seligman, Constitutionalizing the Corporation: The Case for the federal Chartering of Giant CorporaTIONS (1976) [hereinafter cited as NADER REPORT]. 
reform proposals share a common deficiency. They lack any real underpinning either in a theoretical understanding of organizational behavior or in an empirical observation of actual corporate decisionmaking. The reformers are not necessarily wrong, but their strategies are based at critical junctures on intuitive guesses in an area in which Forrester's Law makes intuition highly suspect. ${ }^{20}$

What is most lacking here is a workable model of how a corporation behaves internally. We cannot "constitutionalize the corporation" until we understand it. With such a model, lawyers might assume their accustomed role as policy engineers, manipulating the model to achieve desired results. Yet, the absence of such a recognized model is less because the preparatory theoretical work has not been done than it is because of insularity within the legal profession. Although lawyers as a group are frequently inattentive to developments in allied social sciences, the field of corporate law

(2) Federal Control Over the Chartering Process. Here the debate is between the advocates of "federal minimum standards" versus those of direct "federal chartering." Compare Cary, Federalism and Corporate Law: Reflections Upon Delaware, 83 YALE L.J. 663 (1974), with Schwartz, Federal Chartering of Corporations: An Intro. duction, 61 Gro. L.J. 71 (1972). However, the difference between these two positions often seems minor and to involve basically a dispute over their relative palatability to the business community.

(3) Enhanced Stockholder Power. The leading advocate here is Professor Eisenberg. See M. EISENBERG, supra note 12; Eisenberg, Legal Models of Management Structure in the Modern Corporation: Officers, Directors, and Accountants, 63 CALIF. L. REv. 375 (1975); Eisenberg, Access to the Corporate Proxy Machinery, 83 Harv. L. REv. 1489 (1970); Note, A Proposal for the Designation of Shareholder Nominees for Director in the Corporate Proxy Statement, 74 Colum. L. REv. 1139 (1974).

(4) Use of the Securities Laws to Prevent Corporate Misconduct. See Sonde \&. Pitt, Utilizing the Federal Securities Laws to 'Clear the Air! Clean the Sky! Wash the Wind!', 16 How. L.J. 831 (1971); Stevenson, The SEC and the New Disclosure, 62 CoRnell L. Rev. 50 (1976).

The Nader proposals have met with almost unanimous skepticism. See Corporate Rights and Responsibilities: Hearings Before the Senate Comm. on Commerce, 94th Cong., 2d Sess. 57, 333-36, 381-83, 383-85 (1976) (statements of A.A. Sommer, Jr., Detlev F. Vagts, Donald E. Schwartz, \& David Ratner. Mr. Sommer is a former SEC Commissioner, and the latter three witnesses are professors of corporate law at Harvard, Georgetown, and Cornell, respectively.).

20 Far from disagreeing with many of these proposals, particularly those of Professor Eisenberg, I am impressed by their logic. But, absent a theoretical model and some means of verification (which only the social sciences can provide), there is little basis either for concluding that a given strategy has worked or, if it has failed, for hypothesizing a more likely alternative approach. The case for a theoretical model rests chiefly on the predictive power it should give us, not on any claim that it will disprove earlier commentators. 
presents an egregious example of cultural lag. Dominated by centuries-old fiduciary concepts borrowed from the law of agency and the law of trusts, corporate law has not considered to any significant degree the relevance of the social sciences. Ironically, the one discipline that corporate law has borrowed from at allneoclassical economics-now faces challenge from within its own ranks, on the grounds that it too has ignored the internal tensions that actually shape the behavior of the individual firm. ${ }^{21}$ As a result, both corporate practitioners and legal academicians tend to view the corporation as a "black box," ${ }^{22}$ which need not be understood in its internal workings in order to be operated.

This phenomenon of cultural lag probably is most acute in the area that is the focal point of this article: the problem of corporate accountability. While law students still are drilled in the fundamentals of directors' duties, most empirical observers of the corporation have long discounted the significance of the board, ${ }^{23}$ and microeconomists have virtually dismissed the topic as unworthy of theoretical interest. ${ }^{24}$ Of course, this disdain in itself does not imply

21 Professor Oliver Williamson of the University of Pennsylvania and Harvard Professors John Kenneth Galbraith and Harvey Leibenstein have challenged the orthodox view of the firm as automatically seeking to maximize value for its shareholders. See Corporate Control, supra note l; MARKETS and HIERARChIEs, supra.note l; J.K. GalBraith, supra note l; H. LeIBENSTEIN, Beyond Economic MAN (1976). Galbraith's emphasis is on the inertial forces within the large corporation that make it seek stability and assured growth, rather than risk and competition. Williamson, in contrast, focuses on the diseconomies of scale that hobble the large corporation and make the structure of the corporate hierarchy often more important than the structure of the market. Leibenstein, the most heretical of the three, has coined the term "selective rationality" to express his views that individuals making economic decisions only sometimes act to maximize economic gains. In common, all have developed economic theories of corporate behavior that find previously undiscovered dynamics at work within the corporate hierarchy and that reject the simplistic notion that the sole corporate motivation is profit maximization.

22 This phrase is borrowed from C. STONE, WhERE THE LAW ENDS 121 (1975). Stone has defined many of the central themes examined here-the problems of information flow within the corporate hierarchy, the limited utility of negative reinforcement, the conflict between individual goals of managers and those of the organization-better than any other contemporary legal writer. See generally id. For other attempts to connect behavorial theory and corporate law, see Conard, supra note 1, and Rohrlich \&: Rohrlich, Psychological Foundations for the Fiduciary Concept in Corporation Law, 38 Colum. L. REv. 432 (1938).

23 The classic in this regard is M. Mace, Directors: MYTh and Reality $47-48$ passim (1971). For a summary of recent findings, see M. EISENBERG, supra note 12, at 139-41. See also S. Vance, The Corporate Director: A Critical Evaluation (1968); Feis, Is Shateholder Democracy Attainable?, 31 Bus. LAw. 621 (1976).

24 It is virtually impossible to find an economist who has devoted serious attention to the board of directors. Williamson and others have suggested explicitly that the chief 
that the law should follow suit, because it has special concerns that may justify an emphasis on normative principles. But, when preoccupation with the normative obscures our understanding of the organizational realities underlying corporate behavior, then it serves not as an effective means of analysis, but only as a set of intellectual blinders. Thus, a subsidiary theme of this article is that the "fiduciary ideology" of corporate law has resulted in a tunnel vision that has led reformers to frame issues of corporate accountability in terms of how a fiduciary would behave if guided by "the punctilio of an honor the most sensitive." ${ }^{25}$ Unfortunately, not all problems reduce themselves neatly to questions of honorable conduct or are resolvable simply by exercising other admirable virtues, such as diligence and foresight. Some problems addressed in the next section of this article seem to require structural reform, a possibility that fiduciary ideology inherently ignores.

What is most regrettable about the poverty of the intellectual resources underlying contemporary corporate law is that the last two decades have seen substantial growth in a variety of disciplines focusing on organizational behavior and the actual processes of decisionmaking within institutions. Political scientists have examined the difficulties experienced by those possessing formal authority within organizations in securing compliance with their policies; ${ }^{26}$ they have described the bargaining required for such officials to obtain consensus from their own subordinates, ${ }^{27}$ and have dissected the defensive strategies employed by those below to resist commands from above. ${ }^{28}$ Similarly, communication theorists have studied the information flow within corporations and suggested methods by which a fuller and more accurate flow of rel-

executive officer and his staff have assumed the traditional role of the board in the modern decentralized corporation. See text accompanying note 161 infra.

25 The quotation is, of course, from then-Chief Judge Cardozo's description of the "standard of behavior" expected of a fiduciary in Meinbard v. Salmon, 249 N.Y. 458, 464, 164 N.E. 545,546 (1928).

26 See G. Tullock, supra note 1, at 142-93 passim. For a study of one corporation, see G. Dalton, L. Barnes, \& A. Zaleznik, supra note 1.

27 On the subject of the "side payments" that have to be made within the organization to hold together a coalition of subunits for any given objective, see Cyert \& March, A Behavioral Theory of Organizational Objectives, in MOdern ORGanization THeory, supra note 1 , at $76,78 \cdot 83$.

28 On the topic of group defenses of organizational stability, see Dubin, Stability of Human Organizations, in MOdern ORGanization Theory, supra note 1, at 218, 237-43. 
evant data can reach top decisionmakers. ${ }^{29}$ Psychologists and motivational experts have assessed the conflict between the aspirations of the individual and those of his organization, ${ }^{30}$ the effects of this tension upon behavior of subunits within the firm, and the tendency of individuals holding middle-echelon positions in the corporate hierarchy to become captives of their unit, rather than enforcers of the policies of senior management. ${ }^{31}$ Other theoristsincluding students of game theory, business school professors, and microeconomists-also have emphasized the centrifugal forces within organizations that lead individuals and units to pursue subgoals which are either irrelevant or contrary to overall corporate goals. ${ }^{32}$

This work has an obvious relevance, which corporate law has largely ignored, to the phenomenon of corporate misconduct. There remain commentators still content to describe reality with the simple norm, expressed in numerous state corporation codes, that "the board of directors shall manage the business and affairs of the corporation." ${ }^{33}$ If pressed, some will retreat to the position that the board "possesses" the corporation's authority, but has "delegated" it to senior management." The persistence of this confusion of the normative and the empirical, forty-five years after Berle and Means first reported that the locus of power within the

29 See J. EMery, supra note I, at 1l-66; J. MARch \& H. SinIon, supra note I, at 158-60; Corporate Control, supta note 1, at 25-35; Markets and Hierarchies, supra note 1 , at 122-24; Dubin, supra note 28, at 227-29; Marschak, Efficient and Viable Organization Forms, in MOdern Organization Theory, supra note 1, at 307, 313-20. A recent major synthesis of decisionmaking research ably summarizes modern developments in this area. See 1. Janis \& L. Mann, Decision Making, 10-41, 179-80 (1977).

30 See C. ARGYRIs, supra note 1; R. LIKERT, supra note I; Haire, Introduction-Recurrent Themes and General Issues in Organization Theory, in MOdern OrGanization TheorX, supra note I, at I, 4-6.

31 See Corporate Control, supra note 1 , at 47-52.

32 See id. at 47-52; Haire, supra note 30, at 5.

33 For a list of the standard authorities that still recite this view, see M. EISENBERG, supra note 12, at 2 n.2. See also id. at I40-41; H. HeNN, LAw of CoRporations $\S \S 203,207$ (2d ed. 1970).

34 See, e.g., H. HeNn, supra note 33, at $\$ 212$. Delaware recently has amended section 141(a) of its Corporation Law to indicate that the corporation is to "be managed by or under the direction of" the board of directors. DEL. CoDE ANN. tit. 8, § I41(a) (Supp. 1976) (emphasis added). The ABA's Committee on Corporate Laws has adopted similar revisions in section 35 of the Model Business Corporation Act, apparently in the belief that such a change might reduce the liability of the outside director. See ABA Comm. on Corporate Laws, Report of Committee on Corporate Laws: Changes in the Model Business Corporation Act, 30 Bus. LAw. 501, 502, 504-05 (1975). 
corporation had shifted to senior management, ${ }^{35}$ is disappointing. But it is even more obsolete today, when the contemporary organization theorist tells us that power within the modern decentralized corporation is a very elusive commodity, one seldom effectively monopolized by any one group or level in the corporate hierarchy, not even senior management. ${ }^{36}$

Our focus obviously has expanded to include consideration of more abstract issues than simply the legality of improper payments. The specific topic of such payments, however, does provide a microcosm in which we can approach the broader questions and test the utility of those insights offered by the organization theorists. Professor Christopher Stone has already posed the scope of our basic inquiry. ${ }^{37}$ What ideal configuration of authority and information flow within the corporation, he asks, would ameliorate the current dysfunctions? ${ }^{38}$ For our purposes, this inquiry divides into three parts: (l) to what extent can we discern patterns in a specific controversy, such as the improper payments controversy, that correspond to the abstract models suggested by theorists; (2) to the extent we see such relationships, can these theoretical models suggest remedies; and (3) to what extent are those remedies feasible? In turn, this last question subdivides into two parts: (I) to what extent are the proposed remedies achievable by the present common law, and (2) to what extent is legislative reform necessary?

These questions serve as the roadmap for this article. Part I will consist of a search for criteria. It will move from the specific to the abstract, from a survey of individual cases of malfunctioning to the increasingly rarefied generalizations of the theorists. Thereafter, Part II will survey the common law relevant to corporate misconduct that has evolved in the context of the derivative suit. Again, the principal concern will be an attempt to identify those legal doctrines, either existing or foreshadowed in the case law, that relate to the critiques developed in Part I. To the extent that the

35 See note 12 supra.

36 Essentially, this is what Williamson means when he refers to the "control loss phenomenon" in large decentralized corporations. See Corporate Control, supra note I, at 14-35. For a fuller explanation of Williamson's views and the critical "span of control" concept that he and Mason Haire share, see text accompanying notes 155-61 infra, and Haire, Biological Models and Empirical Histories of the Growth of Organizations, in Modern Organization Theory, supra note 2, at 272, 293-305.

37 See C. Stone, supra note 22.

38 Id. at 120-21. 
potential of the common law does not satisfy the needs of theory, we at least may define the areas which demand legislative reform.

Finally, in Part III, a comparison of models for reform is attempted in light of recent experience with SEC efforts to utilize the securities laws to reform corporate behavior through mandatory public disclosure. ${ }^{39}$ The criteria that have been developed in earlier parts will be used to evaluate the potential of this major new external approach to corporate reform. The drumbeats of this impending advance of "therapeutic disclosure" ${ }^{40}$ have not gone unheard. The private bar has vigorously attacked the Commission's jurisdiction to use disclosure as a means designed less to protect investors than to achieve substantive reform of corporate conduct. ${ }^{41}$ Particularly where the amount of the payment is economically insignificant, the claim has been made with some merit that the SEG is using disclosure not to provide a disinfecting sunlight, but only the artificial klieg lighting for a carefully staged morality play in which the businessman has been forcibly miscast

39 For a sympathetic overview, see Herlihy \& Levine, supra note 2, and Stevenson, supra note 19. For a detailed description by SEC officials of the mechanics of current SEC practices with respect to questionable payments cases, see the following three articles in Volumes $I$ and II of ALI-ABA Course of STUdy: Fraud, INSIDE INFORMation, ANd FIDUCIARY DUTY UNDER RULE 10b-5 (May 12-13, 1977) [hereinafter cited as ALI-ABA STUDY]: Ferrara \& Brandon, Questionable Foreign Payments Decried and Decreed: Securities and Exchange Commission Enforcement Actions, in 2 ALI-ABA STudY, supra, at 689; Ferrara \& Williams, Deputizing the Private Sector: The Hired Hands Search for Sensitive Payments, in 1 ALI-ABA STUDY, supra, at 429; Levine \& Ferrara, Tradition or Corruption: The Defendants and the Volunteers in the Securities and Exchange Commission's Domestic Questionable Payments Program, in 1 ALI-ABA STUDY, supra, at 33.

40 See Sommer, Therapeutic Disclosure, 4 SEc. REg. L.J. 263 (1976).

41 See Borden, The S.E.C. Should Not Be Making Law, N.Y. Times, March 6, 1977, § 3 (Business and Finance), at 12; Freeman, The Legality of the SEC's Management Fraud Program, 31 Bus. LAw. 1295 (1976); Lowenfels, Questionable Corporate Payments and the Federal Securities Laws, 51 N.Y.U. L. REv. 1 (1976); Address by Bruce Allan Mann to ABA Comm. on Federal Regulations of Securities, 1975 Annual Convention (Aug. 20, 1975), reported in [July-Dec. 1975 Transfer Binder] SEc. REg. \& L. REP. (BNA) No. 316, at A-4. Perhaps the most articulate critic of the SEC's current policy is former SEC Commissioner A.A. Sommer, Jr., who was present at the creation of the SEC's "management fraud" policy. See, e.g., Address by A.A. Sommer, Jr., A Parting Look at Foreign Payments, before the Ohio Legal Center Institute (Apr. 2, 1976); Address by A.A. Sommer, Jr., The Slippery Slope of Materiality, before the Practicing Law Institute (Dec. 8, 1975). See also S.E.C. Is Criticized by Outgoing Aide, N.Y. Times, Apr. 5, 1976, at 51, col. 5. For another critical view, see Malley, Far-Reaching Equitable Remedies Under the Securities Acts and the Growth of Federal Corporate Law, 17 WM. \& MARY L. REv. 47 (1975). 
as the stereotypical villian. ${ }^{42}$ Although the issue of the Commission's jurisdiction has been debated elsewhere, ${ }^{43}$ and is beyond our scope, the limits of disclosure as a remedy must concern us. Disinfectants are not, after all, a universal panacea; sometimes surgery is required. Thus, Part III compares the basically internal reforms discussed in Parts I and II against the external remedy of mandatory disclosure of corporate misconduct under the securities laws.

A topic beyond the scope of this article is that perennially debated theme, the corporation's social responsibility. We need not reach this question, because it may be assumed that the interests of the corporation itself, whether narrowly defined as only long-term profit maximization or broadly defined in terms of greater social objectives, are likely to be better served in a closely regulated economy by corporate decisionmaking that is reflective, deliberate, and risk conscious.

\section{Toward a Theoretrcal View: From Observation to Monel Building}

What basic patterns of conduct are discernible from a comparative examination of the experiences reported to date by corporations that have disclosed "questionable payments"? This section outlines that information and then, in ascending order of abstraction, moves from the particular controversy of improper payments to the more generalized empirical observations that commentators have recently offered about corporate decisionmaking, and finally to the pure models of the organization theorists.

\section{A. A Quick Tour of Yesterday's Headlines}

Improper payments stories first began to trickle out from the swamp of Watergate when the Special Prosecutor's Office discovered that a sizable number of American corporations had made

42 See, e.g., Despite Early Gains, Anti-Payoff Campaign Is Beginning to Sputter, Wall St. J., July 9, 1976, at I, col. 6 (comments of chairman of management consulting firm of Booz, Allen, \& Hamilton). Those chief executives who have been removed as a result of questionable payment disclosures have been quick to portray themselves as victims of a witch hunt and have raised the troubling theme that their fiduciary duties to their employees justified making payments not strictly forbidden by law in order to save the jobs generated, for example, by a major aircraft contract. See Kotchian Calls Himself the Scapegoat, N.Y. Times, July 3, 1977, § 3, at 1, col. 1; J. McCloy, supra note 3, at 105.

13 See sources cited notes 40 \& 41 supra. Most recently, the SEC's own Advisory Committee on Corporate Disclosure has concluded that the use of disclosure "to serve groups 
illegal political contributions during the 1972 presidential campaign. This freshet quickly swelled to a steady stream with the subsequent investigation initiated by the SEG to determine whether the absence of disclosure surrounding these payments had violated the federal securities laws. ${ }^{44}$ The floodstage was reached, however, only after the revelation of an unrelated and unsuspected scandal: "Bananagate." The dramatic exposure of United Brands misconduct occurred after the suicide of its prominent chief executive officer, Eli Black, whose death followed the commencement of an SEC investigation into a $\$ 1.25$ million payment, authorized by Black, to the President of Honduras, apparently to avoid the imposition of a confiscatory export duty on bananas. "B5 "Bananagate" shifted the focus of both SEC and popular attention from illegal domestic political contributions to the broader issues arising out of foreign and commercial bribery. ${ }^{46}$ It thus set the stage for the unfolding of the incredible saga of Lockheed Corporation and its worldwide efforts to bribe senior ministers of friendly foreign governments. ${ }^{47}$ Other notable instances of such payments, such as those of Gulf in South Korea, Exxon in Italy, and Northrop and Grumman in the Middle East, have been described in detail elsewhere, ${ }^{48}$ and in the aggregate suggest a level of corporate hubris and unchecked ambition reminiscent of Commodore Vanderbilt and the nineteenth century robber barons.

The SEC's course tacked several times during these developments, reflecting well-publicized disagreements within the Commission. ${ }^{49}$ While its staff was experimenting with increasingly

other than investors would exceed the Commission's statutory authority." Advisory Panel Supports SEC Disclosure Plan, Wash. Post, Nov. 4, 1977, at B9, col. 6.

44 For a concise summary of these events, see SEC PAYMENTS REPORT, supra note 2, at 2-6; Herlihy \& Levine, supra note 2, at 548-58; Kohlmeier, supra note 2.

45 Tracy, supra note 2, at 146; Wall St. J., Oct. 14, 1976, supra note 8.

46 Brownlee \& Queenan, supra note 2, at 27.

47 See Lockheed Paid $\$ 38$ Million in Bribes Abroad, Wash. Post, May 27, 1977, at E9, col. 1; Wall St. J., supra note 6.

48 With respect to Gulf and Exxon, see the reports of their special investigations listed note 3 supra. With respect to Northrop, see Wall St. J., Dec. 15, 1976, supra note 8. With respect to Grumman, see Herlihy \& Levine, supra note 2, at 561-62; Iranian Aide Attacks Grumman President on F-14 Sale Issue, Wash. Post, Sept. 29, 1976, at A2, col. 5.

49 Former Commission Chairman Hills has conceded that there has been disagreement among the Commission members in this area and has acknowledged "uncertainty" as to his own position. See Address by Roderick M. Hills to the Association of the Bar of the City of New York (Mar. 15, 1976). Former Commissioner A.A. Sommer, Jr. 
strong negative incentives, in the form of novel consent decrees, ${ }^{50}$ against questionable payments, the Commission itself seemingly adopted a positive incentive policy almost by inadvertence. ${ }^{51}$ Faced with a potentially enormous number of companies that had made such payments, and thus a severe burden on its enforcement resources, the Commission instead inaugurated in the summer of 1975 its Voluntary Disclosure Program. Under it, companies making voluntary "generic" disclosures of the aggregate amount and basic purposes of questionable payments (and agreeing to take certain other remedial steps) could escape both the constraints of a consent order injunction and the embarrassment of having to make public the delicate details of who got what, when, and why. ${ }^{62}$ The combined effect of the SEC's approach was a carrot-and-stick policy: the ability to make a "generic" disclosure rather than a full scale public confession constituted the "carrot," with the "stick" being the Enforcement Division's increasingly restrictive consent decree. Unquestionably, it worked. The SEC's initiation of this differentiated policy triggered a deluge of corporate disclosures involving several hundred companies. ${ }^{53}$ Thus, to state a theme to which we will return, one lesson about influencing corporate behavior that stands out in overview from this "brief but passionate era of corporate history" 54 is that of the efficacy of combining positive and negative incentives.

has been most critical. See notes 40-41 supra. Both former Commissioner Garrett and Commissioner Loomis have been described as "uncertain" and equivocal in their attitudes towards the recent trend of the Division of Enforcement's management fraud program. Stevenson, supra note 19, at 69. Only Commissioners Pollack aud Evans appear to have given unqualified endorsement to the view that acts involving illegality or misconduct are "per se" material. See The Corporate Rush to Confess All, supra note 2, at 22: Address by John R. Evans, SEC-Catalyst for Competitive Free Enterprise, before the Brookings Institution (Mar. 25, 1976). In contrast, the most recently appointed member of the Commission, Roberta Karmel, has indicated that she is "not terribly concerned" about the questionable payments controversy, but is "wary" of attempts to legislate corporate morals. See A New Perspective at the S.E.C., N.Y. Times, Nov. 27, 1977, $\$ 3$ (Business \& Finance), at 5 , col. 1 .

50 See text accompanying notes 543-47 infra; Ferrara \& Brandon, supra note 39; Kohlmeier, supra note 2.

51 See Stevenson, supra note 2, at 72.

52 For descriptions of the Voluntary Disclosure Program, see SEC PAYMENTs RePorT, supra note 2, at 6-13; Herlihy \& Levine, supra note 2, at 584-94.

53 The Corporate Rush To Confess All, supra note 2; Wall St. J., supra note 4.

54 Address by Roderick Hills, Doing Business Abroad-The Disclosure Dilemma, Yale Law School (May 1, 1976), reprinted in 23 YALE L. REP., Fall, 1976, at 4, 8. 


\section{B. The Basic Patterns: An Arrangement In Gray and Black}

Distinguishing degrees of impropriety is always an uncomfortable task. Such an attempt here is not only disquieting, but difficult. As we penetrate behind the black-and-white world of the newspaper headlines, the colors of the surrounding landscape become increasingly dominated by the muted grays of moral ambiguity and legal uncertainty. As in a Whistler canvas, grays and blacks blend into each other in a way that obscures basic patterns. Nonetheless, a moral continuum is discernible on which the prototypical foreign payments would rank in the following descending order of culpability.

\section{The "Aggressive" Payment}

As the disclosures about Lockheed, Northrop, and other corporations have made clear, the success of some American corporations has apparently depended on management's secret skills in the private auction market of commercial bribery. In such cases, the race may not have gone to the most efficient, but rather to the most corrupt.

However, before we frame a remedy based on the assumption that the Lockheed case is typical, it is important to note that the best evidence to date suggests that this form of bribery, the large payment directly exchanged for new business, is more the exception than the rule. Of the first 100 corporations to participate in the Commission's Voluntary Disclosure Program, "fewer than twenty," according to Chairman Hills, could be so classified. ${ }^{.5}$ Similarly, a self-reporting survey conducted by the Conference Board indicated that such practices tended to characterize only certain industries, most notably heavy capital goods industries, particularly those selling to government purchasers. ${ }^{56}$ Companies possessing a substantial competitive edge, especially in high technology equipment, have proven largely immune to such bribe requests. ${ }^{67}$

65 Id. at 6.

66 See J. Basche, Unusual foreign Payments: A Survey of the Policies and Practices OF U.S. Companies 15-17 (1976).

57 Trowbridge, Foreword to $i d$., at v. 


\section{The "Defensive" Payment}

What then is the characteristic improper payment? Both the SEC Payments Report and a report by the Conference Board have found that the leading targets of requests for improper payments were precisely those companies that are most dependent on the attitudes of government regulators. Pharmaceutical companies and corporations involved in petroleum refining stood out in particular. In each case, the characteristic profile is that of a business that makes relatively low sales to governmental purchasers but is highly sensitive to political control. ${ }^{58}$ In the view of the involved corporate officials, the payments were felt necessary to protect existing operations against adverse political actions.

The difference between the "aggressive" payment and the "defensive" payment to avoid adverse governmental action is presumably the element of duress. Arguably, duress may supply a defense to corporate officials in a derivative suit brought with respect to such payments. ${ }^{59} \mathrm{But}$, putting aside temporarily this tactical consideration, how valid is the distinction between aggressive and defensive payments? Some nuances emerge if we contrast two celebrated examples of defensive payments: Gulf Oil and United Brands. The case of Gulf Oil in South Korea provides the clearest paradigm. With a $\$ 300$ million fixed investment in South Korea, Gulf's chairman received threats in 1970 from officials of the dominant Korean political party that the company's investment would be jeopardized unless it made a $\$ 10$ million "contribution" to that party ${ }^{60}$ Similarly, in the case of United Brands, where the threatened catastrophe to the company from a confiscatory export duty on bananas appeared at least as great, the original bribe request came from Honduran officials. ${ }^{61}$ But, unlike Gulf's situation, the payment to the President of Honduras was designed to frustrate a deliberate governmental policy, collectively agreed upon with

58 J. BASche, supra note 56, at 16-17; SEC PAYMENTs RePort, supra note 2, at 37. A survey by the Council on Economic Priorities has found that out of the first 175 companies to disclose, 22 were in the drug and health care field, 22 in the oil and gas industry, 14 in aerospace and air travel industries, and 14 in chemicals. 175 Firms Admit Bribes of $\$ 300$ Million Overseas, Wash. Post, Dec. 19, 1976, at D13, col. 1. Thus, four industries account for roughly one-third of the total experience.

59 See notes 393-406 infra and acompanying text.

$60 \mathrm{~J}$. McCloy, supra note 3, at 101-05.

61 United Brands Bribe Called "Aberration," N.Y. Times, Dec. 11, 1976, at 29, col. 5. 
several other Central American nations. Because of this aspect, the United Brands example forcefully raises the questions of whether there should be limits to a duress defense and whether we can seriously postulate a corporation's right to determine for itself that governmental action is sufficiently arbitrary to justify resistance by extra-legal means.

Even if there are necessary limits to any exculpatory concept of duress, it still must be asked: who caused the losses in these cases? If we grant that sometimes the payment of bribes, even if illegal, mitigates or averts larger losses to the corporation, traditional common-law concepts, such as proximate causation, interfere with our ability to use the common law to deter corporate misconduct. ${ }^{62}$ Arguably, liability should not accrue to the corporate officer whose actions, while harmful, result in net beneficial effects to the corporation. In other words, even if the Gulf and United Brands cases can be distinguished in terms of the relative justification for the payment (Gulf alone having been threatened with extra-legal pressures), they are alike in two other respects. First, the payments were made to avoid a larger loss. Second, permitting the individual shareholder to sue derivatively and hold corporate officials strictly liable for such payments would enable him to prevent the corporation from defending itself in a way that the majority of shareholders might prefer. The nagging root question here raised (consideration of which must be postponed) concerns the extent to which the derivative suit should serve as the vehicle for the private attorney general.

\section{The "Grease" Payment}

By far the greatest number of revelations have not involved large bribes intended either to secure new business or to protect existing operations. Rather, the most frequent payments have been relatively small sums delivered to lower echelon officials to expedite services, to avoid bureaucratic red tape, or to obtain the performance of duties to which the corporation is entitled. Such

62 The problem of proximate causation is discussed at text accompanying notes 407-15 infra. Also complicating the issues in this United Brands example is the often overlooked fact that the public policy of Honduras, which United Brands attempted to frustrate, was the formation of a price-fixing cartel whose existence certainly was contrary to United States policy. Thus, to argue that a U.S. corporation must always comply with local public policies may be unduly simplistic. 
"facilitating" payments-variously called "tea money" in Asia, "dash" in Africa, "pots de vin" in Europe, "baksheesh" in the Middle East, and "la mordita" in Latin America-characteristically are made for prosaic purposes such as obtaining permits or allocations of scarce resources. ${ }^{63}$ To the extent such grants involve an exercise of discretion by the official receiving the payment, it is usually a very limited discretion and generally in a context in which such payments unofficially are recognized as traditional. ${ }^{64}$ Revealingly, even those in Congress who have most adamantly opposed foreign bribes have carefully exempted the grease payment from the scope of proposed criminal proscriptions. ${ }^{65}$

In the initial reaction against questionable payments, a number of American corporations adopted sweeping codes of ethics that proscribed all forms of questionable payments, including the ubiquitous grease payment. ${ }^{66}$ Since then, a number of companies have found such a goal to be unattainably idealistic and have in a variety of ways quietly conceded the inevitability of venial $\sin .^{67}$ In some cases, this concession has even taken the form of the

63 See J. BASChE, supra note 56, at 4-5, 9-12; SEC PAYMENTS REPORT, supra note 2, at 26-27; Hills, supra note 54, at 6 .

64 Gwirtzman, supra note 2, at 100 .

65 For an exhaustive summary of all recent legislative proposals, see Ferrara \& Williams, Saints and Sinners Revisited: The Legislative Approach to Questionable and Illegal Corporate Payments, in 2 ALI-ABA STudy, supra note 39, at 529 (summarizing the contents of 31 recent legislative bills). Representative of the stricter form of legislative approach, which makes specified types of payments actually illegal rather than simply requiring their disclosure, is S.305, 95th Cong., Ist Sess., 123 Conc. Rec. S7193 (daily ed. May 5, 1977). The bill was proposed by Senator Proxmire, Chairman of the Senate Banking Committee, and was approved in slightly different versions by both the Senate and the House. At the time this article went to press, both houses had agreed to the conference report on S.305. See Corporate Bribery Bill Is Approved, Wash. Post, Dec. 8, 1977, at DI, col. 6. While it contains tough criminal penalties, the bill is carefully tailored to reach only payments made directly or indirectly to governmental officials and political parties, thus excluding the grease payment. See also 122 ConG. Rec. S15,789 (daily ed. Sept. 14, 1976) (statement of Senator Proxmire with respect to predecessor of S.305 in 94th Congress; noting that the bill's definition of "bribery" was narrowed).

66 During late 1975 and 1976, the issuance of guidelines and corporate codes of ethics became an almost obligatory item on the agenda for innumerable corporate boards. See SEC PAYMents REPORT, supra note 2, at 45-46; More Concerns Issue Guidelines on Ethics in Payoffs Aftermath, Wall St. J., Mar. 16, 1976, at 1, col. 6. For representative examples, see J. BASCHE, supra note 56, at 30-42 (most of which provide no exceptions for "grease payments").

67 Several corporations have publicly announced that they will continue to make "grease" or "facilitating" payments. SEC PAYMENTS REPorT, supra note 2, at 46-48; Wash. Post, supra note 58. 
institution of formalized procedures for senior management review of requests by subordinate officials to make such payments. ${ }^{68}$

Once again, issues of legal significance surface. Should the common law of fiduciary duty tolerate some level of venial sin when committed by a corporate official in the shareholders' interest? Or must the law deal in moral absolutes? If the latter course is the answer, it can be assumed that such grease payments, although de minimis on an individual basis, are sufficiently large in the aggregate that, after public disclosure under SEC prodding, they will attract the attention of the derivative suit bar. Thus, the hidden corollary of these questions may be whether we prefer a structure in which senior management can monitor and supervise the involvement of subordinates in questionable activities, or do we prefer to maximize the symbolic repudiation of such conduct, thereby fostering a system in which senior management may not accept the risk of liability that would come with a close monitoring of grease payments? If this is the net effect of a "moralistic" legal response, the upshot may be to encourage management to respond with the averted glance of the "shut-eyed sentry"-a consequence potentially leading to greater disaster.

\section{Bribery by Proxy: Use of the Middleman}

As the SEC's investigation intensified during 1975, an assortment of exotic and unsavory characters began to emerge from the woodwork of obscurity-and then to reappear with astonishing regularity. These middlemen ${ }^{69}$ proved to be ubiquitous because

68 In most of the cases where companies have not completely terminated such payments, the approach taken has heen to authorize them only "if no reasonable alternative exists" and if approved by senior management. SEC PAYMENTS REPORT, supra note 2, at 46-48. Bristol-Meyers in fact has apparently adopted detailed procedures for the supervision of questionable payments under which they must be reported to its audit committee unless "insubstantial in amount" or approved by its general counsel. Bristol-Meyers Questions $\$ 3$ Million in Payments, Wash. Post., Sept. 10, 1976, at D-11, col. 5. The goal here seems to be greater accountability rather than total elimination. In addition to this shift to procedural reform, as opposed to substantive prohibitions, some observers have questioned whether companies are truly enforcing the policies to which they publicly subscribe. See Wall St. J., supra note 42 , at 1 , col. 6.

69 The best known of these was the flamboyant Adnan Khashoggi, who was simultaneously the agent of Northrop, its competitor Lockheed (from whom he has earned $\$ 106$ million in commissions), and a number of other American corporations. Sampson, supra note 2. Notwithstanding his notoriety, he apparently remains the agent of some major American corporations. Wall St. J., supra note 42, at 1. 
they fulfilled a vital corporate need: the creation of a "buffer zone," "70 an insulating layer between the corporation and actual involvement in any negotiation over a bribe. Should the activities of the agent result in scandal, the corporation can then profess dismay and disown its agent.

From a common-law perspective, deliberate use of such an approach presents a number of familiar issues dressed in only slightly altered guise. These include the traditional problem of form versus substance, and the tension between the principle of respondeat superior and the common law's general distaste for vicarious liability. For our purposes, however, the more important question is whether the game is worth the candle if such a simple subterfuge can solve corporate management's legal problems. Even if the veil of this artifice can be pierced, will the next obvious solution, turning the agent into either a consignee or an independent layer in the distribution network, achieve the same result? Perhaps this would be the likely consequence of placing American corporations at a disadvantage vis-a-vis their European counterparts. ${ }^{71}$ If so, the main message here may be to reconsider the moralistic approach and focus more carefully on what it is we want to change.

\section{The "Legal" Political Contribution}

At the other end of the continuum that began with the "aggressive" bribe lies the lawful political contribution. While contributions by corporations to candidates in federal elections long have violated United States law, ${ }^{72}$ no such prohibitions exist in many other nations, ${ }^{73}$ and even in some states. ${ }^{74}$

70 See J. BASCHE, supra note 56 , at $13-15$, on the utility of such a device for many corporations.

71 Basche suggests that some American corporations use "distributors, agents, [and] franchisees" for exactly this reason. Id. at 13.

72 This prohibition is now codified as part of the Federal Elections Campaign Act. See Pub. L. No. 94-283, § 112(2), 90 Stat. 490-92 (1976) (to be codified at 2 U.S.C. $\S 441 \mathrm{~b}$ ), discussed in Cort v. Ash, 422 U.S. 66 (1975).

73 Examples are Germany, Italy and Switzerland. See generally J. BAScHE, supra note 56, at 6-7.

74 A recent survey prepared for a Practicing Law Institute conference shows 16 states without any such prohibition. See Practicing Law Instrrute, The Corporation in Politics 93-117 (1976). A number of other states permit some corporate contributions, generally below a specified dollar level. See id. 
The result is that " $[w]$ hen political contributions are lawful, they are expected and solicited, and a business enterprise cannot be sure of the impact of a refusal." "While some contributions appear to be barely disguised "aggressive" and "defensive" bribes, a fair characterization of the majority of political contributions is that they seem intended less to obtain a specific benefit than to obtain a favorably disposed "attentive ear" within government in the event of future problems. ${ }^{76}$ The payments are analogous to insurance premiums: in return for a sum immaterial to the corporation, access to political decisionmakers in a future crisis is assured.

The largest corporate political contributions on record-those totaling nearly $\$ 60$ million made by Esso Italiana S.P.A., an Exxon affiliate-reveal above all else a basic confusion of motives. Eventually, a major reason for their continuation became the self-perpetuating fear of reprisals for terminating such a sizable program. ${ }^{77}$ While some payments resembled bribes intended to resolve contractual disputes with government agencies, ${ }^{78}$ and others were somewhat quixotically motivated by a desire to forestall the spread of the Italian Communist Party, the predominating motive was again this desire to preserve an "attentive ear." 79

Ultimately, the Exxon case seems more interesting as a symptom of several distinct problems than as a substantive evil itself. First, the corporation somehow spent nearly $\$ 60$ million for uncertain purposes without triggering any internal alarm that alerted the board of directors. Second, it appears that for years before the payments program was terminated, the president of Exxon's Italian subsidiary had resisted pressure and even commands from Exxon's senior management to cease and desist such practices. ${ }^{80}$ Third, the devices by which the recalcitrant official was able to resist senior management "generated an atmosphere of non-control," ${ }^{81}$ which

\footnotetext{
75 EXXON REPORT, supra note 3, at 31.

76 See Note, Civil Responsibility for Corporate Political Expenditures, 20 U.C.L.A. L.

REv. 1327, 1348 \& n.111 (1973).

77 EXXON REPORT, supra note 3, at 25.

78 Id. at 33, 53-56.

79 "The unarticulated hope is . . . that, in decisions involving judgment or discretion, the disposition toward the donor will be, if not sympathetic, at least free from hostility ...."Id. at 31 .

80 Id. at 24-28.

81 Political Slush Fund Hid Other Spending, Cost Exxon Millions, Wall St. J., Nov. 14,
} 
itself may be of more concern than any substantive evil involved. Thus, Exxon's Italian Connection is a symptom not only of the board's remoteness from the corporation's internal functioning, but also of another tendency, one that organization theorists call "persistence behavior." 82 That term refers to the inertial force that seems to exist within some organizations leading a subunit within the organization to continue in a pattern of behavior because of the "sunk costs" involved, long after the conduct in question has become counterproductive to the enterprise as a whole. ${ }^{83}$

\section{The Undefined Duties}

Incomplete as the foregoing account of "improper payments" may be, it suffices to provide our microcosm. Disregarding for the moment any discussion of the legal duties of corporate officials, we can detect four different sets of pressures acting upon the typical middle-level managers who usually receive such payment requests. First, they face the competitive pressure of corporations based outside the United States, which to date appear not to have been inhibited by the burgeoning dimensions of the scandal within the United States. ${ }^{84}$ Second, they are acutely aware of the uncertain and shifting nature of the line that separates extortion from bribery. Third, they are under the pressure created by the weight of precedent and the inertial force that keeps a program, once commenced, in operation. Commercial bribery has a long, if not honorable, history, antedating even the corporation itself. ${ }^{85}$ Finally, the fourth factor is the atmosphere of rampant moral relativism

1975, at 1, col. 6, \& 24, col. 1. See note 510 infra (comments of Exxon's former general auditor).

82 MARKets and Hierarchies, supra note 1 , at 121.

83 For other examples of such recurring behavior, see notes 128-32 infra.

84 See Herlihy \& Levine, supra note 2, at 565-66 (describing the more tolerant French and British attitudes toward questionable payments and their amusement at the moralistic reaction of the United States). The French defense ministry has apparently become popularly known in some quarters as the "Ministry of Bribes." Multinational Corporations and United States Foreign Policy: Hearings Before the Subcomm. on Multinational Corporations of the Senate Comm. on Foreign Relations, 94th Cong., 1st Sess., pt. 12, at 354-55 (1975).

85 Herlihy \& Levine, supra note 2, at 560; see Guzzardi, supra note 2, at 118 (noting that Bethlehem Steel won the contract to supply steel for the Trans-Siberian railroad at the turn of the century by making a gift of a diamond necklace to the mistress of the Czar's nephew); Gwirtzman, supra note 2, at 19 (pointing out that such practices were used by the early joint stock companies, such as the East India Company, before the 
in which the corporate manager of a multinational corporation operates abroad. It is not only that "everybody does it," but that managers and others are profoundly divided and uncertain as to whether they must abide by the moral standards predominant in the United States or by the local "rules of the game." 86

These factors have a generalized significance that transcends the context of illegal payments. Competitive pressure, the inevitability of operating "close to the line" in some areas of the law, the force of tradition, and the existence of conflicting standards are equally characteristic of environmental, antitrust, tax, and other legal and social problems to which the corporate manager must respond.

Ironically compounding the middle-level manager's dilemma, in a way that also may be representative, has been the inconsistent, even contradictory, performance of governmental regulators. Reputable businessmen have reported that officials of the State and Treasury Departments in some localities have carefully coached them as to whom to bribe, whom to refuse, and what middlemen to hire as sales agents. ${ }^{87}$ Even more aggravated has been the degree of involvement of the Defense Department, which appears to have haggled recurrently over the size of the bribes to be paid on foreign arms sales. ${ }^{88}$ Such involvement by the federal government renders understandable the skepticism on the part of corporate managers when confronted with official rhetoric about corporate morality. If one single scene could sum up this transition from complicity to condemnation, it would be that moment in Casablanca, when

corporation as we know it existed). Former SEC Chairman Hills also has noted that the history of commercial bribery stretches back "for centuries." Hills, supra note 54, at 6.

86 See J. BASCHE, supra note 56 , at 25 (reporting that $48 \%$ of the executives responding to a Conference Board survey answered that American companies were entitled to adopt the prevalent "commercial modes and moral standards" of the countries where they did business, even if those conflicted with standards in the United States). Before we fault businessmen too quickly for their uncertainty on this point, it should be noted that Yale Divinity School Professor Charles W. Powers has argued that bribery may be morally defensible in some cultures. Powers and his colleagues argue that a multinational etnical code must be based on the host country's values, not those of the United States. J. Simon, C. Powers, \& J. Gunneman, The Ethical Investor (1972). See also Ethics Experts Wax Inconclusive on Bribery Abroad, N.Y. Times, Aug. 3, 1975, $\$ 3$ (Business and and Finance), at 1, col. 1 .

87 E.g., How A Multinational Avoids Paying Bribes Overseas - Probably, Wall St. J., April 14, 1976, at 1 , col. 6, \& 15, col. 1 .

88 Sampson, supra note 2, at 53 (describing meetings between Pentagon officials and Adnan Khashoggi). 
Claude Rains as the venal chief inspector announces his shock at the gambling in Rick's Cafe-and then is handed his winnings.

Hypocrisy is, of course, an ancient prerogative of governments and bureaucrats. The point here is only that, if we could achieve a stronger corporate superego without visiting harsh retribution on all subordinate corporate officials who act unwisely in what they believe to be the best interests of the corporation, such an approach would seem desirable from the standpoint of fairness. Additionally, by creating some safe harbors for the corporate executive, such a legal strategy might meet far less resistance from within the corporate community.

\section{The Breakdown in Corporate Norms}

If the individual corporate manager seems an undeserving scapegoat, where then should responsibility lie? If we feel that the directors of the corporation have functioned as little more than "shut-eyed sentries," they become inviting targets. But if we seize only on evidence that confirms this critique, we tend to filter out many of the particularly troubling characteristics of the improper payments phenomenon. For example, a study of the Gulf debacle more pointed and less diplomatic than the McCloy Report found not so much inattention on the part of the board as deliberate concealment of information by officers of the corporation. ${ }^{89}$ Actual deception by the chief executive officer in the face of direct inquiries from the board accompanied a disturbingly slow and indifferent investigation by the orginal outside counsel retained by the board. ${ }^{90}$ Similarly, neither the United Brands nor Lockheed boards appears to have received notification from its chief executive about matters involving fundamental risks to which its

89 Robertson, supra note 2, at 121. This study notes that (1) Gulf Chairman Dorsey "kept secret from the board, for more than a year and a half after the scandal broke, the fact that he had personally authorized the largest political payments- $\$ 4$ million" to South Korean officials, and (2) "Gulf's general counsel and lawyers retained by the company withheld some devastating details that they had turned up . ..." Id. While diligent, the board "found it difficult to pierce the veil of politeness" and get truthful information from its own employees. Id. at 122.

90 The attorney initially retained to conduct the investigation "volunteered very little of what he knew" and failed to give the board a full accounting of illegal campaign contributions until eight months after he had given the same information to the Watergate Special Prosecutor. Id. at 124. 
business was subject. ${ }^{91}$ Before dismissing these boards as passive entities populated by "decoy duck" directors, we must note that the Gulf and Lockheed boards, once fully informed, did act decisively and removed their chief executives. ${ }^{92}$

Thus, the problem of inadequate information flow to the board is significant. In $40 \%$ of the cases studied in the SEC Payments Report, senior management was aware of the payments and the surrounding circumstances. ${ }^{93}$ "Inside" directors also frequently were conversant with these practices. ${ }^{94}$ But in no case does the report clearly indicate that the outside directors were apprised of the situation. ${ }^{95}$ Rather, elaborate steps appear to have been taken to prevent disclosure to the board. ${ }^{96}$ Compounding this deliberate isolation of the board has been the behavior of the outside professionals. In Gulf and several other instances, the attorneys appear to have been highly selective in the information they revealed to the board. ${ }^{97}$ More frequently, the outside accountants have tolerated the creation of "slush" funds ${ }^{98}$ and the falsification of corpo-

91 See also Exxon REPorT, supra note 3; J. McCloy, supra note 3. This phenomenon of selective revelations by senior management to the board is not limited to large or traditionally profit-oriented corporations. For a tale of similar deception by the President of the First Women's Bank, see Welles, Ms. Management at the First Women's Bank, New YoRK, Apr. 4, 1977, at 78 .

92 As is well known, the chief executives of Gulf and Lockheed were fired, and Northrop Chairman Jones was forced to surrender his title of President. See articles cited note 8 supra. Nor are these instances atypical. There have been an "unprecedented" number of instances recently in which boards have removed chief executives in whom they had lost confidence or by whom they felt deceived. Barmash, Heads Rolling in the Board Room, N.Y. Times, Oct. 17, 1976, $\S 3$, at 1 , col. 3 (noting that the chief executive officers recently had been fired at " 20 of America's best known companies" and attributing this trend to a new assertiveness on the part of the board).

93 See note 11 supra.

94 See SEC PAYMENTS REPORT, supra note 2, app. A.

95 See id.

96 Id. at 42.

97 See, e.g., note 90 supra. Similar accusations have been made in other recent cases. Summarizing the recent report of Lockheed's special review committee, the Wall Street Journal has noted that "the name of . . . [Lockheed's] chief counsel and assistant secretary is sprinkled throughout the pages of the report in connection with helping to facilitate questionable payments." Lockheed Puts Foreign Payoffs Near $\$ 38$ Million, Wall St. J., May 27, 1977, at 4, col. 2. See also Kickbacks, False Statements by Emersons Alleged, Wash. Post, Jan. 5, 1977, at C6, col. 1.

98 The Internal Revenue Service's study of corporate slush funds found them to exist in 54\% of the 896 corporations studied. SEC Forces Delay in Falstaff Brewing Stockholder Meeting, Wash. Post, June 7, 1977, at D6, col. 5. In most cases, the accountants at some point became aware of the general nature of the payments program. 
rate books and records without notifying the board, even in instances where an audit committee existed to serve as a conduit by which such information could reach the board.9" The "almost universal characteristic" of the cases the SEC studied was "the apparent frustration of our system of corporate accountability." 100

In short, if the fundamental principle of corporate government is that the board of directors shall manage the corporation, then the improper payments controversy has exposed a number of extreme instances of corporate malfunction. Three basic symptoms, none wholly distinguishable from the others, appear with some regularity. Each is discussed in turn below.

\section{The Dominance of Operations over Policy}

A maxim of business behavior, so well recognized by businessmen that it has become something of a cliché, is that "operations make policy." ${ }^{101}$ In the absence of clearly articulated and enforced policy guidelines, short-term concerns will override and indeed shape long-term goals. Given this tendency, it is revealing that the Conference Board found that only $25 \%$ of the corporations it surveyed had written guidelines concerning the permissibility of questionable payments. ${ }^{102}$ While many of the rest claimed to rely on oral guidance and unwritten rules, the general picture that emerged from the survey was one of relatively little restraint on basically autonomous managers. In most cases, enforcement of these written or unwritten rules depended almost totally on the

99 In the Lockheed case, Arthur Young \& Company discovered the payments in 1971 and brought them to the attention of the corporation's audit committee on two occasions, but senior management was able both times to prevent the audit committee from alerting the full board. Wall St. J., supra note 97 . In the case of Gulf, its outside accountants had "some knowledge" of Gulf's foreign payments. J. McCLoy, supra note 3, at 205-09. However, although Gulf had an audit committee since 1971, there is no indication that they discussed any of these payments with the committee. Id. at 212.

100 Introduction to SEG PAYMENTS ReporT, supra note 2, at (a).

101 C. BRown, supra note 9, at 32. One distinguished social scientist observed that in fact many chief executive officers of large firms tend to give an almost irrational priority to short-term goals that " $[t]$ hey are single-mindedly, almost slavishly, committed to achieving ...." Argyris, The CEO's Behavior: Key to Organizational Development, Harv. Bus. Rev., March-April, 1973, at 55, 57. That this happens is of course further testimony to the difficulties inherent in making the board into a balancing force capable of "moderating the management's understandable internal interest in day-to-day achievement." Andrews, Can the Best Corporation Be Made Moral?, Harv. Bus. Rev., May-June, 1973, at 57, 64. $102 \mathrm{~J}$. BASCHE, supra note 56, at 18-19. 
use of financial controls to detect unauthorized payments. ${ }^{103}$ Only in a few cases did companies report a practice of instructing managers that they would be evaluated in terms of their ability to live within the guidelines promulgated. ${ }^{104}$ Reports of disciplinary actions taken against noncomplying employees were rare. ${ }^{105}$ Against such a backdrop, even where written guidelines exist, the corporate manager may perceive the instructions from above as amounting to little more than that time-honored injunction: "Don't Get Caught."

\section{The Imbalance Between the Board and the Chief Executive Officer}

The fairest generalization that can be made on the evidence to date about the role of the board in the illegal payments controversy is that its function usually has amounted to little more than crisis intervention. Generally, only when affairs have gotten so out of hand that management has been discredited has the board asserted itself, often under pressure from derivative suit plaintiffs. ${ }^{106}$ Perhaps the best evidence of the eclipse of the board as a source of policy is the finding of the Conference Board that in $75 \%$ of the surveyed cases, managers were subject to no more than unwritten guidelines regarding foreigu payments. ${ }^{107}$ Necessarily, oral guidance comes from corporate officers and not from the board; inherently it is subject to varying interpretations, and often is formulated on an ad hoc basis at times when shortrun goals loom irresistably large. It is also virtually immune from review and supervision by the board. In short, dependence upon oral guidance and informal advice undercuts the board's monitoring capacity, because it is frequently difficult to reconstruct, particularly in the aftermath of a debacle, just where responsibility for a given decision lay.

103 Id. at 22.

$104 I d$. at 24.

105 See id. at 22-24.

106 In cases such as Gulf, Northrop, and Lockheed, it seems particularly clear that the board acted only after litigation had been commenced and a demand made on the board pursuant to FED. R. Civ. P. 23.1.

107 See J. BAsche, supra note 56, at $18-19$. 


\section{The Problem of Information Blockages}

Adverse information, particularly information relating to contingent liabilities, appears not to be reaching the board until a crisis has become unavoidable. ${ }^{108}$ The improper payments controversy provides several hundred recent examples of serious structural deficiencies in the information flow and internal compliance monitoring within large corporations. ${ }^{109}$

A variety of reasons appear to share responsibility for these information blockages: (a) a shared feeling on the part of subordinate officials that they owe their loyalty chiefly to senior management and not to the board; (b) a belief that the board is interested only in "hard" quantitative information, such as capital costs, financial ratios, and expected rates of return; (c) a sense that "everybody knows anyway," coupled with the perception that the board would rather not be put on formal notice as to the ugly "facts of life" of doing business abroad; and (d) a "lack of congruence" between the interests of the corporation and the career aspirations of individual corporate officials. ${ }^{110}$ More simply, this last point means that what is good for General Motors is not necessarily good for its Assistant Vice President. If he fails to use sensitive payments, or if he discloses to his superiors any questionable practices he does use, he may appear less successful than his compatriots who hide such information from their superiors. To be sure, the tendency to report information selectively, emphasizing the positive while filtering out the negative, is characteristic of all bureaucratic organizations (whether the information relates to guerrilla

\footnotetext{
108 On the pervasiveness of this problem, see C. STONE, supra note 22, at 201-09.

109 The Lockheed situation provides a particularly good illustration of how such information blockages can develop within a large organization so as to prevent critical information from reaching those with primary monitoring responsibilities. An "informal internal organization" that made or approved the payments and prevented others from becoming. aware was found to have evolved within Lockheed. For example, Lockheed's chief financial officer, who should have been aware of such payments, was excluded from this process and was largely "the victim of a plan by [Lockheed's senior two executives] to keep him uninformed." Wall St. J., supra note 97. A similar "informal" organization within the corporate bureaucracy has been reported in the case of Firestone, whose chief financial officer ran a domestic political contributions program without the knowledge of any other corporate official. See Firestone Inquiry Finds Officer Ran \$1.16 Million Fund, N.Y. Times, Dec. 24, 1976, at DI, col. 1. See also How the Bond Balloon Burst At Chase, Fortune, July, 1977, at 78 (describing how one relatively senior bank official withheld information about his own \$34 million misjudgment); notes 510-11 infra.
}

110 C. STONE, supra note 22 , at 46. 
warfare in Vietnam, environmental hazards of a major governmental project, or the illegal means by which a profitable contract has been secured). But distinguishing the corporate context is the comparative absence of any institutionalized mechanisms by which to penetrate and break down these information blockages. While armies have inspectors general, and governmental projects face the necessity of environmental impact studies, no currently enforced legal norm requires the corporation to internalize a means of forcing potentially adverse information to the attention of the board.

How serious is the need for a legal strategy tailored to these problems? To answer this question, we need to take a broader look.

\section{E. An Overview of Internal Corporate Decisionmaking}

In appraising the improper payments controversy, the first idea to discard is that it is unique. A close parallel to the current controversy was the major price-fixing conspiracy uncovered throughout the electrical equipment industry in the late 1950's. ${ }^{111}$ Then as now, moralists were shocked, Congress concerned, and business spokesmen baffled at the dimensions of the scandal. But one anomaly of that scandal has special relevance to the current controversy: despite the size of the conspiracy and subsequent careful scrutiny, no evidence was uncovered of involvement by the senior management of any of the major participants.

In the aftermath of that scandal, both congressional committees ${ }^{112}$ and commentators ${ }^{113}$ identified several common root causes within the structure of the participating corporations that had permitted the conspiracy to continue undetected for a substantial period. First, senior management had been unable to communicate to the operating levels of the corporation its concern about exposure to antitrust liabilities. ${ }^{114}$ Second, this failure of internal communications was compounded by a fixed belief on the part of subordinates aware of the formal corporate policy that senior

111 For a comprehensive study of this period, see Whiting, Antitrust and the Corporate Executive Part I, 47 VA. L. Rev. 929 (1961), and Whiting, Antitrust and the Corporate Executive Part II, 48 VA. L. REv. 1 (1962). Some 29 corporations and 44 individuals were indicted. 47 VA. L. REv. at 929 n.l.

112 See Administered Prices: Hearings Before the Subcomm. on Antitrust and Monopoly of the Senate Comm. on the Judiciary, 87th Cong., 1st Sess., pt. 28 (1961).

113 See Whiting, supra note 111, at 48 VA. L. Rev. 15-18.

114 Id. at 15 . 
management did not really mean what it said. ${ }^{115}$ Third, senior management was so isolated from those at operational levels as to be effectively unable to monitor or control closely conduct at operational levels. ${ }^{116}$

The problem of management isolation from operations was in turn found to be the product of a series of factors, such as a decentralized corporate structure, ${ }^{117}$ a hierarchical command system that required orders and responses to travel along narrow linear channels of communication, ${ }^{118}$ and a technical orientation of those at operational levels that made them inattentive to both the signs and risks of illegality. ${ }^{119}$ One study of that conspiracy found that even when subordinates had sought to protest orders they considered questionable, they found themselves checked by the linear structure of authority, which effectively denied them any means by which to appeal. ${ }^{120}$ For example, one almost Kafkaesque ploy utilized to prevent an appeal by a subordinate was to have a person substantially above the level of his immediate superior ask him to engage in the questionable practice. The immediate superior would then be told not to supervise the activities of the subordinate in the given area. ${ }^{121}$ Thus, both the subordinate and the supervisor would be left in the dark regarding the level of authority from which the order had come, to whom an appeal might lie, and whether they would violate company policy by even discussing the matter between themselves. By in effect removing the subject employee from his normal organizational terrain, this stratagem effectively structured an information blockage into the corporate communication system. Interestingly, there are striking similarities between such an organizational pattern and the manner in which control over corporate slush funds deliberately was given to lowlevel employees, whose activities then were carefully exempted from the supervision of their immediate superiors. ${ }^{122}$

115 Id. at 16.

116 Id. at 17.

$117 I d$. at 18 .

$118 I d$.

$119 I d$ *

$120 \mathrm{Id}$. at 17 . In addition, one cardinal rule recognized by the participants in the price fixing was "not to tell the lawyers anything." Id. at 17-18.

121 Id.

122 The classic recent example is that of William Viglia, Gulf's admitted "bagman" in the Bahamas. A low-level employee, he was totally detached from the ordinary chain of 
Other examples of gaps in what Christopher Stone has called the corporation's "information net" are not hard to find. ${ }^{123}$ In each case, the result is to interdict the upward flow of adverse information. But, the problem is hardly unique to the area of corporate misconduct. Recent SEG studies of such corporate collapses as Penn Central ${ }^{124}$ and Stirling Homex ${ }^{125}$ have found the boards to have been unaware of the impending disasters. While the SEC has cited these instances as evidence of inadequate diligence by the outside directors, others have identified a different pattern: the systematic censorship by those controlling the flow of information to the board of warning signals that might have alerted outside directors. ${ }^{126}$ Surveying a host of examples, Peter Drucker, the acknowledged dean of American theorists on management, has observed that the board "was always the last group to hear of trouble in the great business catastrophes of the century." ${ }^{127}$

But why? An example that reveals in more microscopic detail what Drucker has observed on the macroscopic level is the recent

command, with no immediate superiors or associates familiar with his activities. Viglia reported directly to Gulf's Pittsburgh home office rather than its nearest regional office in Coral Gables. See J. McCloy, supra note 3, at 42-61. Viglia's activities were sufficiently shielded from his superiors that even Gulf's Comptroller was once told by Gulf's Executive Vice President not to inquire into them despite the large flows of cash to Viglia. Viglia himself appears to have understood that he could not describe his activities even to such a high ranking official. See Ex-Chief of Gulf's Bahamian Unit Says Silence Was Ordered on Political Fund, Wall St. J., Dec. 12, 1975, at 5, col. 1. Such a pattern is, of course, a paradigm of what this article terms an "information blockage." The purpose of this extreme secrecy was not only to prevent external discovery of the payments, but also to keep those within the organization who would protest from discovering. See J. McCloy, supra note 3, at 33. See note 109 supra for instances fitting a similar pattern at Lockheed and Firestone.

123 C. Stone, supra note 22, at 199.

124 Special Subcomm. on Investigations of the House Interstate and Foreign Commerce Comm., 93d Cong., 2d Sess., The Financial Collapse of the Penn Central. ComPANY (Subconm. Print 1972) (Staff Report of the Securities and Exchange Commission). See also C. STONE, supra note 22, at 196.

125 Staff of the Securities and Exchange Commission, Report of Investigation in the Matter of Stirling Homex Corporation Relating to Activities of the Board of Directors of Stirling Homex Corporation, [1975-1976 Transfer Binder] FED. SEc. L. REP. (CCH) If 80,219 (July 16,1975 ).

126 See Harris, Directors of Industrial Companies: Special Problems, 31 Bus. LAw. 1235, $1237-40$ (1976).

127 P. Drucker, supra note 1, at 628. See also J. Argenti, Corporate Collapse: The Causes AND SYmptoms 121-32 (1976) (reviewing the common symptoms in most major recent corporate insolvencies and finding "one-man rule" by a managerial "autocrat" to be the most common factor). 
insolvency of W.T. Grant Co., the giant retailer. ${ }^{128}$ A major cause of the collapse was Grant's lack of even rudimentary internal controls over inventory or credit. Those at lower echelons within the corporation exploited this lack of central control by deliberately contriving an upward flow of misinformation. As the final collapse approached, for example, the company's buying department appears actually to have increased its purchases of large capital goods items, where profit was least likely, in order to prevent cutbacks in its own staff. ${ }^{129}$ Similarly, individual store managers unrealistically extended credit to meet their own sales quotas. ${ }^{130}$ In some cases, vendors were even deliberately overpaid, subject to an oral agreement to treat the overpayment as a loan, so that store managers could manipulate their fourth quarter profits to show a rising trend at year's end by recalling these loans. Given the weakness of the internal controls, it should not be surprising that there also was evidence of suspicious payments resembling kickbacks. ${ }^{131}$ This pattern of conflict between the interests of the subunit and those of the firm equally characterizes corporations not on the brink of insolvency. Recently, the Washington Post uncovered a similar example, involving two wholly owned subsidiaries of U.S. Steel. Both of the subsidiaries have been actively lobbying with regard to proposed legislation, but on opposite sides. ${ }^{132}$

Economists and other theorists have termed this type of organizational schizophrenia "subgoal pursuit."133 The theory is that given an opportunity to exercise discretion, managers at lower levels within a firm will tend to act not to maximize the firm's welfare, but rather the interests and autonomy of their own unit or division. ${ }^{134}$ Such behavior is virtually inevitable, organization theorists have found, because the subunit chief executive who fails to act as the zealous advocate of the interests of his own unit, even when those interests conflict with the firm's overall welfare, "is not apt to

128 For studies of the W.T. Grant debacle, see Investigating the Collapse of W.T. Grant, Bus. WEEK, July 19, 1976, at 60; Grant Testimony Shows It Lacked Curbs on Budget, Credit and Had Internal Woes, Wall St. J., Feb. 4, 1977, at 6, col. 3.

129 Wall St. J., supra note 128.

130 Id.

131 Id.

132 Corporate Killer Fish Are Circling Waterway-Tolls Bill, Wash. Post, June 19, 1977, at $\mathrm{Al}$, col. 1 .

133 See, e.g., Corporate Control, supra note 1 , at 47-49.

134 Id. at 47-52, 174; MARKETS AND HIERARChIEs, supra note 1 , at 125. 
be viable for long." ${ }^{135}$ The captive of his constituency, he must act as the partisan representative of its interests or risk abandonınent by his own subordinates. Thus, even at this still mild level of abstraction, the problem of information blockages ceases to be only a technical failure of communications or the consequence of careless inattention, but becomes instead part of a predictable and deliberate strategy rationally employed by lower echelons to protect their own interests from both senior management and the board alike.

Similarly, the other symptoms noted earlier-the imbalance between the executives and the board and the tendency for operations to shape policy-also become clearer at a more generalized level of abstraction. Increasingly, recent commentators have diagnosed the root problem to be the absence of any functioning system of checks and balances within the corporation. ${ }^{136}$ Empirical surveys have documented the limited impact of the board in most forms of corporate decisionmaking. ${ }^{137}$ Boards do not set policy, do not veto management, seldom intervene short of a major crisis, and do not even select their own successors or the next chief executive officer. Why is the board so unable to exercise control? Here the empirical approach of observation and reportage is inadequate to answer this question in any depth. Instead, it is necessary to turn to a higher level of abstraction and to the organization and communication theorists who have examined the modern large firm.

Studying governmental bureaucracies in the 1960's, Gordon Tullock observed the phenomenon of "authority leakage." $\mathrm{He}$ described this as a progressive loss of control over subordinate units within the same bureaucracy as the organization expanded and the distance between such units and those at the agency's top

135 Corporate Controx, supra note 1 , at 5l. Central to this argument is that the modern organization is a "prolific generator of anxiety and insecurity." V. THompson, Modern Organization 24 (1961), cited in Corporate Control, supra note 1, at 5I; see M. MAcсову, supra note I, at 189-90 (containing considerable empirical evidence on the level of anxiety among corporate managers). As a result, each subunit within the organization has a bias for expansion and growth in order to create more opportunities and security for its members. Given this virtually instinctive urge to grow, Williamson argues, the subunit will abandon, undercut, and eventually revolt against any functional chief who seeks to restrict its expansion. See also Burns, On the Rationale of the Corporate System, in The Corporate Society, supra note 1, at 121, 160-66.

136 See, e.g., C. Brown, supra note 9, at 15-21.

137 The most notable is that by Harvard Business School Professor Myles Mace. See M. MACE, supra note 23. For a summary by Professor Mace of his findings, see Conard, Mace, Blough, \& Gibson, Functions of Directors Under The Existing System, 27 Bus. LAw. 23, 32-37 (Special Issue Feb. I972). 
became greater. ${ }^{138}$ Subsequently, another student of bureaucracies, Anthony Downs, formalized Tullock's perception into a general law, the "Law of Diminishing Control," which states: "The larger any organization becomes, the weaker is the control over its actions exercised by those at the top." ${ }^{139}$ Both Downs and Tullock found one underlying cause of this progressive paralysis to be the ease with which generalized orders and nonspecific policies imposed at the top could be successively reinterpreted, distorted, or qualified as the commands filtered downward through the organization. By analogy, a corporate code of ethics, adopted in general terms by a board, would seem to be at least as subject to an increasingly selective reception and reinterpretation as the organizational distance from the board increases as were the commands in the bureaucracies studied by Tullock and Downs. Interestingly, tentative confirmation of this hypothesis already may have emerged from the improper payments controversy. There is evidence suggesting that those at the top of the corporate hierarchy have ceased their use of "improper payments" while those at lower levels are persisting. ${ }^{140}$

On the reverse side of the coin to the problem of "authority leakage" are the problems associated with the upward transmission of adverse information within the corporate hierarchy. ${ }^{141}$ To the extent that corporate communications are basically serial in nature, so that information is retransmitted from each hierarchical level to the next, the Theory of Cognitive Dissonance suggests one problem. That theory simply states the much-observed phenomenon that recipients of information unconsciously focus on and relay only the information that reinforces their preexisting attitudes, while filtering out conflicting information. ${ }^{142}$ To the

138 G. Tullock, supra note 1 , at 142-93.

130 A. Downs, supra note 1 , at 143. For a discussion of both theorists by Williamson, see Corporate Control, supra note 1 , at 26.

140 See N.Y. Times, supra note 6. Gulf's vice president in charge of internal auditing has said that even when senior management is adamant, there may still be continuing instances at lower levels: "It's like turning off a faucet. You still might get a drop or two." At Gulf Oil Nowadays, A "Questionable" Deal Is One To Be Shunned, Wall St. J., Jan. 25, 1977, at 1 , col. 6. In the language of the organization theorist, this is "persistence behavior." See Markets and Hierarchies, supra note 1 , at 121.

141 See Corporate CONTROL, supra note $\mathrm{I}$, at 22, 25-26.

142 The premise of the Theory of Cognitive Dissonance and of several related theories is that the human mind has an innate drive to maintain consistency between its preexisting attitudes and the information it receives. Hence it filters out much information that is inconsistent with these prior attitudes. See L. Festinger, A Theory of Cognimve 
extent that adverse information conflicts with the recipient's basic attitudes by showing failure, it is particularly subject to this unconscious filtering.

Even absent the distorting impact of preexisting attitudes on information flow, experimental evidence suggests that serial relay of information results in significant information loss. ${ }^{143}$ Information theorists have formulated the rule that each additional relay in a communications system halves the message while doubling the "noise." 144 Significantly, some corporations have today between twelve and fifteen hierarchical levels between the first-line supervisor and the company president, suggesting that much "noise" and only a very diluted message will reach the top through regular lines of communication. ${ }^{145}$ The economist Kenneth Boulding has phrased the problem the most pessimistically: "[T]he larger and more authoritarian the organization, the better the chance that its top decision-makers will be operating in purely imaginary worlds." ${ }^{146}$ There appears to be no easy solution to this problem. Communication theorists agree that to enable all of the units of a large corporation to communicate directly with senior decision-

Dissonance (1957); C. Hovland, I. Janis, \& H. Kelly, Communication and Persuasion (1953); M. Rokeach, The Open and Closed Mind (1960); H. Schroder, M. Driver, \& S. Streufert, Human Information Processing (1967). But see I. Janis \& L. Mann, supra note 29 , at $15-16,82-85,420-22$, for recent revisions in this theory.

143 Particularly illustrative are F. C. Bartlett's studies, in which information was serially communicated along a chain of individuals in order to study the cumulative loss. He found that after such serial transmission:

[O]pinions and conclusions are reversed-nearly every possible variation seems as if it can take place, even in a relatively short series. At the same time the subjects may be very well satisfied with their efforts, believing themselves to have passed on all important features with little or no change ....

F. BartLetT, Remembering 175-81 (1932), quoted in CoRporate Control, supra note 1 , at 25. See also MARKETS AND HIERARChIEs, supra note 1, at 122-24.

144 P. DRUCKER, supra note 1 , at 546.

145 Id. at 546-47. Drucker adds that any "level" in an organization is equivalent to an additional "relay" in a communications system.

146 Boulding, The Economics of Knowledge and the Knowledge of Economics, AM. Econ. Rev., May, 1966, at 1, 8, quoted in Corporate Control, supra note 1, at 22. Nobel prize-winning economist Kenneth Arrow has defined the problem in slightly different terms: information to deal with a problem may be available within the organization and yet not become accessible to senior decisionmakers because of "the overload of the informamation and decisionmaking capacity of the authority" and the resulting tendency to filter out information that is not "congruent with previous beliefs." $\mathrm{K}$. ARRow, ThE Limits of ORGANIZATION 73-75 (1974). 
makers would be to create an overload of information that would be an even more serious problem. ${ }^{147}$

The factors that we have considered so far-subgoal pursuit, authority leakage, and the loss of message content during transmission across hierarchical levels-are related phenomena that show the need to penetrate the "black box" perception of the corporation and to understand its internal functioning. Only recently, however, have we seen any attempt to synthesize these factors into a comprehensive model. That attempt, by Professor Oliver Williamson of the University of Pennsylvania, involves a rigorous mathematical treatment that resists summarization. ${ }^{148}$ Starting with the question long debated by economists of whether there is an optimum size to the firm, Williamson examines what underlies the frequently made observation that some giant firms are consistently outperformed by smaller firms in the same industry. His answer is that the loss of internal control within these giants, caused by their greater problems in securing compliance and adequate internal communication, renders them relatively less efficient. ${ }^{149}$

But here Williamson parts company with the static organization theorists, such as Downs and Tullock, who basically take an ahistorical view of the problem and see all bureaucracies as hobbled by the same disabilities. In Williamson's view, the corporation has evolved over time in response to the challenges posed by its internal environment. ${ }^{150}$ Relying largely on the work of the business historian Alfred Chandler, ${ }^{151}$ Williamson notes that about the turn of the century the internal structure of the business corporation assumed a new configuration: decisionmaking began to be decentralized along functional lines. Chief executives began delegating specific functional authority to specialized subordinates. ${ }^{152}$

147 See J. EMERY, supra note 1, at 24-28. This work emphasizes that senior management must "decouple" itself from the majority of incoming lines of communication if it is to avoid sensory overload. A respected computer scientist has reached a related conclusion, arguing that management suffers not so much from the lack of relevant information as from an "overabundance of irrelevant information." Ackoff, Management Misinformation Systems, in Information Technologx in a Democracy 264, 265 (A. Westin ed. 1971). See also X. JANis \& L. MANN, supra note 29, at 21-23.

148 See Corporate Control, supra note 1.

149 See id. at 14-35.

$150 \mathrm{Id}$. ch. 5.

151 See A. Chandler, Jr., Strategy and Structure (1966).

152 Markets and Hierarchies, supra note 1, at 133-36. For a fuller account of this transition to "functionalism," see P. DRUCKER, supra note 1, at 520-23, 563. 
This change was in response to the increasing complexity of business and the overloading that had occurred in the channels of communication leading to the chief executive. It did not, however, truly resolve the overload problem. The chief executive still had to resolve all operational issues that implicated the interests of more than one functional unit. ${ }^{153}$ Borrowing from earlier organization theorists, Williamson argues that the chief executive, and each subordinate manager, has a limited "span of control," a limited range of decisions and operations that he can effectively monitor and control. ${ }^{154} \mathrm{He}$ argues that this turn-of-the-century restructuring of corporations along functional lines merely added a new tier, the special function executive, to the corporate hierarchy, thereby intensifying the problems of subgoal pursuit and communication distortion. It was an ineffective reform because it did not reduce to a feasible range the chief executive's "span of control." ${ }^{155}$

Williamson's next step is critical. A series of internal crises within the largest American corporations during the 1920's proved to the management of these corporations that their organizational structure was inadequate, because it placed excessive operational demands upon the chief executive and his staff. ${ }^{156}$ Their size simply had grown beyond the chief executive's "span of control." In response, these corporations-General Motors, Sears, DuPont, and Standard Oil of New Jersey-each independently developed a new management structure that reallocated the burden of operational decisionmaking from senior to middle-level management by decentralization. ${ }^{157}$ After World War II, most other American corporations followed suit. ${ }^{158}$ At the heart of this transition was the creation of the autonomous centralized division. Self-contained and headed by the divisional equivalent of a chief executive officer, who possessed full operational authority and coordinated his own subordinate functional specialists, the division became virtually an

153 See A. Chandler, supra note 151, at 382-83.

154 See note 36 supra.

155 Markets and Hierarchies, supra note 1, at 133-36, citing A. Chandler, supra note 151 , at $382-83$.

156 See Markets AND Hierarchirs, supra note 1 , at 136-37.

157 Chandler terms the new corporate form that resulted "multidivisional." Under it, operational decisions were entrusted to a divisional chief executive, so that the firm's chief executive could focus on company-wide "strategic" decisions full time. A. CHANdLer, supra note 151 , at 382-83. See also P. Drucker, supra note 1 , at 572-85.

158 Corporate Control, supra note 1, at 117-18 (noting that such firms as Goodyear, General Electric, IBM, Ford, Chrysler, International Harvester, and ITT have imitated 
independent corporation unto itself. A diagram Williamson uses to show this transition appears below: ${ }^{159}$

\section{The Traditional Unitary Corporation}

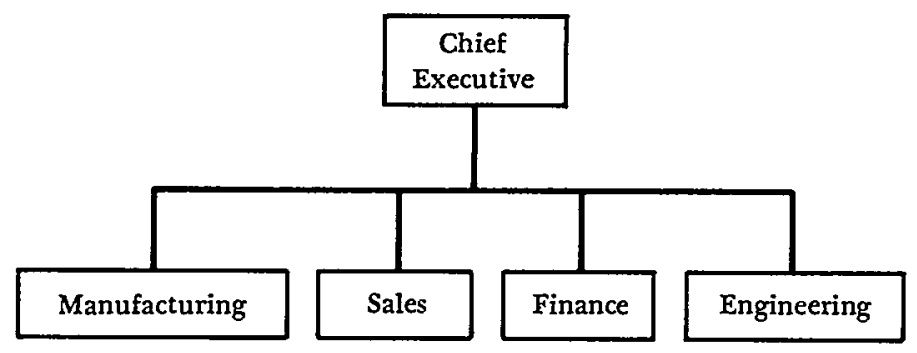

The Multidivisional Corporation

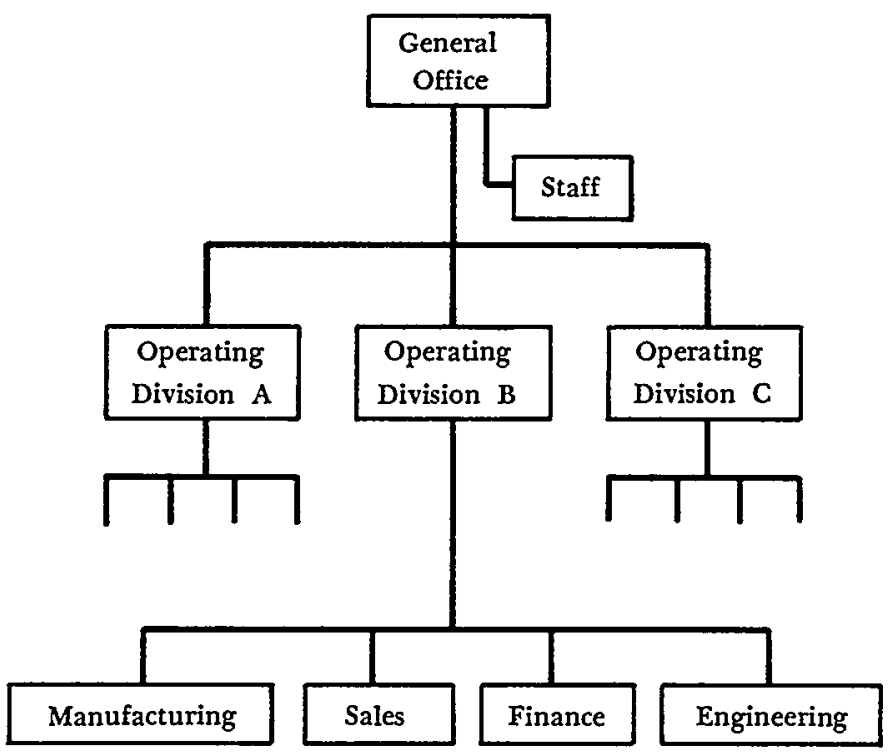

this form). Probably the first academic to recognize the significance of this change was Peter Drucker in his classic study of General Motors. See P. Drucker, THE Concept of THE Corporation (1948). By the late 1950's, with the appearance of the conglomerate, the multidivisional form had become virtually ubiquitous among large corporations. Indeed, some undiversified companies (such as IBM) have found it expedient to simulate decentralization in order to improve decisionmaking, notwithstanding that their activities are not inherently multidivisional. P. DRUCKER, supra note 1 , at 585-91.

159 Corporate Control, supra note 1 , at 116. 
The competitive advantages of this structure in terms of the criteria outlined earlier are clear. First, responsibility for operational decisions has been reassigned to a lower level in the corporate hierarchy, thereby reducing both the responsible executive's "span of control" and the potential for communication distortion or subgoal pursuit. Second, the central office at the apex of the corporation is now "decoupled" from unnecessary channels of communication and has solved its information overload problem by divorcing itself from operational decisionmaking. As a result, it now can focus on both strategic planning and monitoring the performance of each division. It enforces compliance with its strategic goals through auditing and by controlling such incentives as salary, promotion, and allocation of capital among divisions; ${ }^{160}$ in effect, it performs the role of a miniature capital market, rewarding efficient divisions and penalizing inefficient ones-but thereby also encouraging lower echelons to avoid sanctions by withholding adverse information from the top.

There is another consequence of this transition that, although less emphasized by Williamson, is more directly relevant to our concern with the reasons underlying the eclipse of the board. By restricting their focus to planning, formulating policy, and monitoring, the chief executive and his staff assumed functions that were traditionally the prerogative of the board. The consequence of such decentralization was that the senior management group became an " 'activated board of directors' whether or not they are the legally constituted board." ${ }^{101}$ In effect, the management group preempted the legal board. To the extent that senior management and the board performed the same functions, they were engaged in an unrecognized and unavoidable competition, one that normally could only be won by senior management. Having a larger staff, control over such vital incentives as the allocation of capital and promotions, and a full-time commitment to its mission, senior management necessarily would outperform a part-time board.

Most economists and business school academicians probably tacitly share this view of the board as a vestigal appendix of the corporation. But the legal profession, which has a unique interest

160 See Markets AND Hierarchies, supra note 1 , at 137-48, for a summary of the competitive advantages of this form.

161 Heflebower, Observations on Decentralization in Large Enterprises, 9 J. Indus. ECON. 7, 18 (1960). 
in a normative description of the corporation, continues to attribute greater importance to the board. Still, unless norm and reality are reasonably congruent, any effort to reduce corporate misconduct by subjecting the board to unrealistic standards risks being ineffective generally, and punitive occasionally, in its isolated application to random scapegoats. This raises a serious problem about the most popular remedy now being advocated by the SEC, Ralph Nader, and a host of other reformers. They propose the reformation of the board to include either principally or exclusively independent "outside" directors. ${ }^{162}$ However, whether working alone or with a special staff, the corporate board as presently constituted seems incapable of having more than a marginal impact. The implications that flow from Professor Williamson's model are that the board is in the position of the seventeenth century monarchholding absolute power in theory, but cut off from access to information and thereby manipulated by the ministers who are its nominal servants. Occasionally, the board may erupt into forceful action, but in the long run its domination by its ministers seems inevitable. Moreover, this analogy is incomplete, for it fails to convey fully the organization theorist's emphasis on the centrifugal forces within large organizations that result in subunits persisting in conduct disapproved by those at the organization's apex. Even the ministers, it appears, are never in full control of their own bureaucracy.

Organization theory poses some other counter-intuitive implications for possible reforms. If the contemporary board is too passive, a logical reform would seem to be to institutionalize a more adversarial relationship between the board and management. Such a purpose seems to underlie the recent proposals of the Nader group, under which each director would represent a specified special interest constituency, such as environmentalists or consumers. ${ }^{163}$ The board then would represent those groups whose legitimate interests appear most likely to conflict with the corporate

162 There are, however, significant differences in the functions that the "outside" boards proposed by these critics would perform. The Nader board, composed of "public interest" representatives, would manage the corporation, while the board proposed by Professor Eisenberg would seek only to "monitor" management. M. EIsENBERG, supra note 12, at 164-72. Whether the board as presently structured can perform adequately even this more modest monitoring function presents an issue on which I remain skeptical.

163 NADER REPORT, supra note 19. 
goal of profit maximization. But, if one of the basic problems undercutting the effectiveness of the board is that of information blockages, then the clear message from the theorists of bureaucracy is that such blockages are most acute precisely when the lower echelons perceive their relationship with the upper echelons to be adversarial in character. ${ }^{164}$ Similar observations have been made by more empirically oriented observers as well. ${ }^{165}$

To deal effectively with the information blockage problem, it is necessary to understand more about the preconditions for the free flow of information within organizations. A leading motivational expert, Rensis Likert, has summarized the empirical research on information interchange within organizations between subordinates and superiors. Likert explains that to the extent the interaction between them is not "supportive" of the subordinate, ${ }^{166}$ the tendency to withhold information and restrict disclosures increases, and all "communication upward will be highly filtered and correspondingly inaccurate." ${ }^{167}$. He finds that sensitive information is communicated only when the informant has trust and confidence in the recipient and when the informant believes that he can "exert influence upward." 168 Likert finds these preconditions generally are satisfied only when the communication is on a "faceto-face" basis between individuals having prior shared experiences, ideally from having participated in the same working groups. ${ }^{169}$

Can the law refocus its efforts in response to such theoretical input? It seems a fair characterization to say that to date most courts

164 R. Likert, supra note 1, at 49-51, 158-88. Professor Likert's emphasis is on the need for cooperative interaction as a precondition for information sharing. For a briefer exposition of his views, see Likert, $A$ Motivational Approach to a Modified Theory of Organization and Management, in MODERN ORGANIzATION THEORY, supra note 1, at 184 [hereinafter cited as $A$ Motivational $A$ pproach]. Cf. R. Likert, New Patterns of ManageMENT (1967) (an earlier, more general treatment of the types of interaction and successful managerial theory).

165 Examples are Peter Drucker, Courtney Brown, and Roger Blough. For the comments of these men, which have focused on the troubling issue of whether the board should be equipped with a sizeable staff to investigate matters on its behalf, see notes 195-98 infra.

166 See A Motivational Approach, supra note 164, at 190-92, 201-02, 210-11.

167 Id. at $195-96$.

168 Id. at 202.

169 Id. at 192-96. See also W. MorRIs, supra note 1, at 49-51. Within the work group, these theorists agree, information flow is efficient and the tendency to bias or withhold information is greatly reduced. Because interaction within such groups is "supportive," there is a "full and open flow of useful and relevant information," and "[t]here are no blocks, no distortions, no filters." $A$ Motivational Approach, supra note 164, at 210. 
and legal commentators largely have emulated King Canute, relying on fiduciary law principles and simply insisting that subordinates disclose information to their superiors. While this response is understandable, it is also myopic. It fails to ask how the law can best encourage the freer and fuller flow of information within the corporate hierarchy.

Professor Christopher Stone is one legal scholar who has addressed the question of encouraging information flow. However, while he may well be the first corporate law commentator to view this problem other than through the prism of "fiduciary ideology," his answers nonetheless seem potentially counterproductive when analyzed from the standpoint of organization theory. Essentially, he suggests mending the corporation's "information net" in three respects: (1) a greater use of "public interest" directors, who will be more sensitive to social and moral concerns; ${ }^{170}$ (2) a requirement that the corporation gather more information internally about the adverse social consequences of proposed actions; ${ }^{171}$ and (3) a greater protection for the "whistle blower" within the corporate hierarchy who provides notice of impending undesirable activities. ${ }^{172}$ While this summary fails to convey the subtler nuances in Stone's proposals, it is sufficient to point out the problems his suggestions raise from the perspective of the organization theorist. First, reliance on "public interest" directors raises the problems of an adversarial relationship between the board and management. The result may be to aggravate, rather than to alleviate, the problem of information blockages. ${ }^{173}$ Second, the information-gathering requirements resurrect the dangers of information overload and "stimuli saturation," which decades ago forced senior management to "decouple" itself from operational decisionmaking. ${ }^{174}$ Not only would the amount of data be voluminous, but data collection alone does not overcome the tendency of lower-echelon personnel

170 C. STONE, supra note 22 , at 152-73.

$171 \mathrm{Id}$. at $217-27$.

172 Id. at 213-16. See also R. Nader, P. Petkas, \& K. Blackwell, Whistle Blowing (1972).

173 This does not mean that the selection of directors should continue to be controlled by the management they in theory are to supervise, but only that efforts at reform should avoid needlessly creating the appearance of an atmosphere of antagonism or suspicion between the board and the corporate infrastructure.

174. See sources cited note 147 supra. See also Arrow, On the Agenda of Organizations, in The Corporate Society, supra note 1, at 214, 224-30. 
to unconsciously filter out adverse information. For example, to the extent that environmental impact statements have been successful information-gathering devices, much of their effectiveness comes from the existence of judicial review (which would be lacking here) and not from any demonstrated tendency on the part of sponsors of governmental projects to reconsider them voluntarily once all the evidence is in. Finally, dependence on the "whistle blower" seems both unrealistic and counterproductive. As Stone recognizes, legal sanctions are only one of the many forces impacting on the corporate executive. Where sanctions conflict with more powiverful pressures, they will likely prove ineffective even if enforcement is punitive. Yet, near unanimity exists among observers of the corporation that within its hierarchy no act is viewed more disfavorably, indeed seen virtually as "treason," than disclosure of adverse confidential information to outsiders. ${ }^{175}$ Given this attitude toward disclosure, reliance on a "whistle blower" strategy would have little positive effect. Moreover, it would pose a real danger that the near-paranoid sensitivity of corporate managers toward internal spies would intensify the problem of information blockages by causing greater restrictions to be placed on the intracorporate flow of information. ${ }^{176}$

On a more generalized level there is also reason to doubt that a "whistle blower" strategy, depending as it does on seducing key individuals within the corporate hierarchy, can be successful in the long term. As sociologist Robert Dubin has said, "There is a lengthy series of studies that comes to the same general point: that smaller groups in organizations must be viewed analytically

175 See A. Jay, Corporation Man 266 (1971); Markets and Hierarchies, supra note 1 , at 146-47 \& n.12; Burns, supra note 135, at 174. Professor Burns argues that not only is confidentiality "essential to the survival of the system," hut "communication control . . . [is] both the basis and the overt expression of power within the corporate system." Id.

176 Undoubtedly, there have been and will again be instances in which concerned individuals within organizations will "blow the whistle." A recent noteworthy example is the five nuclear engineers with in General Electric who resigned to protest the dangers inherent in nuclear energy. See Disclosing Misdeeds of Corporations Can Backfire on Tattlers, Wall St. J., May 21, 1976, at 1, col. 1. However, efforts to promote such disclosures may be counterproductive, cutting off the flow of information to monitoring stations within the corporation that are far more important than the isolated concerned individual. If protecting the "whistle blower" reduces the total flow of sensitive information within the corporation, it also reduces the effectiveness of the board, once again substantiating Forrester's Law. 
and realistically as organic wholes whose cooperation in the organization must be sought as a unit." 177 To depend seriously on the "whistle blower" is to rely on a strategy that seeks individual cooperation rather than group compliance, one that seeks to encourage an activity universally mistrusted within the corporate social system. Such a strategy too greatly subordinates realism to idealism.

\section{F. A Proposed Model: The Mini-Board-Making Structure Follow Strategy}

By this point, the reader may have decided that we are dismissing useful reforms because they do not fully solve the problem. In fact, there are twin dangers here that any attempt at policy reform must confront. On the one hand, there is a temptation to fall victim to what might be termed the Herbert Spencer Syndrome: the feeling that nothing can be done to change the system and that all governmental action is futile. ${ }^{178}$ If the Spencer Syndrome represents the conservative extreme, the countervailing danger tempting liberals is the fallacy that "all good things go together." ${ }^{170}$ Here, this fallacy is best exemplified by the apparent belief of some recent enthusiasts that a combination of all recent proposals for reform"special constituency" directors, audit committees, enlarged staffs for the board, and more disclosure-would, if applied in large enough doses, somehow solve the corporation's internal problems.

177 Dubin, supra note 28, at 242.

178 See generally H. SPEnCER, Social Statics (1851). For a description of the "ultraconservative" impact of this work upon 19th century thinkers, see R. Hofstader, Social Darwinism in AMErican Thought 31.50 (2d ed. 1955). Analogously, some of the organization theorists, most notably Gordon Tullock, have similarly taken a conservative stance that little can be accomplished through governmental intervention to cure the bureaucratic disabilities they describe. See, e.g., G. Tullock, supra note 1, at 157-60. In contrast, Williamson and others have argued that internal changes within the organization have reduced these problems in the case of the business corporation. See, e.g., Corporate ConTRol, supra note 1, at 117-19. There is, of course, no reason why legislatures or agencies should be denied the opportunity to experiment with such reforms; the reply of Justice Holmes to the Spencerians in Lochner v. New York, 198 U.S. 45, 74 (1905), seems equally applicable here: "The Fourteenth Amendment does not enact Mr. Herbert Spencer's Social Statics...."

179 I borrow this phrase from Gordon Tullock. See Tullock, Does Punishment Deter Crime?, 36 PUb. INTEREsr 103, 109 (1974). For a critical review of recent reform proposals, see Feis, supra note 23. In order to steer a course between these twin obstacles, my suggestion is that an intelligent policy approach should seek to maximize the efficiency of the corporate superego by utilizing the same principles that have been found to maximize the efficiency of the corporate ego (i.e., senior management). 
While such a prescription is pleasantly idealistic, it is based on little more than intuition, since the blinders of fiduciary ideology have prevented an in-depth diagnosis of the problem.

Once one views the problem of corporate control from the perspective of organization theory, prescription flows from diagnosis. The literature of organization theory has given much attention to the possibility of "flattening" organizational structures, i.e., reducing the number of hierarchical levels across which communications must pass. ${ }^{180}$ Shortening the line of communications to the top might minimize distortion in the information transmitted upward and maintain the clarity of the commands sent downward. While some experimental evidence supports the utility of such "flattening," ${ }^{181}$ only an incurable optimist would believe the possibility of such a strategy on a large scale. "Flattening" would conflict with decentralization, which, as Williamson and others have shown, has been a necessary and successful adaptation to the corporation's changed internal environment.

But what possibilities exist for moving the board closer to the locus of the problem? To explore the available alternatives, it is useful to begin with the common metaphor that the board is the corporation's "crow's nest." As such, it can spot impending problems on the horizon, but can hardly discover or correct trouble in the ship's boiler room below. Communications from both crow's nest and boiler room run to the bridge, where senior management holds the helm. Thus, if our concern about the problem of corporate misconduct leads us to seek to make the board better able to monitor the corporation's internal environment, then we must consider a structural repositioning of the board, bringing it closer to the locus- of the problems we want it to monitor. However, as long as the board's manpower is limited, as in the present structure, it cannot both engage in strategic planning and simultaneously monitor internal and external problems with any real effectiveness. This, however, is the same problem of limited management capacity that confronted the corporation earlier in this century, and that was resolved successfully by decentralization. The unitary corporate structure gave way to the multidivisional form discussed

180 See G. Dalton, L. BARnes, \& A. ZalezniK, supra note 1, at 3; Dubin, supra note 28, at 229 (summarizing the literature on this point).

181 See G. Dalton, L. Barnes, \& A. ZalezniK, supra note 1 , for an elaborate empirical study on the effects of such a strategy within one division of a large corporation. 
earlier. In effect, to solve a problem of information overload analogous to that now faced by the board, the chief executive officer surrendered his day-to-day control over operational matters and allocated this authority to several mini-chief executives, positioned at the apexes of their respective autonomous divisions.

If we wish to institutionalize a stronger corporate superego, a similar strategy of decentralization seems in order: the board's monitoring function might be decentralized by creating "miniboards" that would correspond with these same divisional chief executives. Just as the corporation's "ego" was divisionalized several decades ago, so might be its "superego" today. This suggested satellite board structure would involve the introduction of a miniature board of directors at the apex of each division, chiefly to serve as antennae for the central board. In theory, such a change would produce the same reduction in organizational distance between operational levels and the board superego as would "flattening" the entire structure. Moreover, it could do so without creating an information overload on the central board. Such miniboards might be staffed by independent "outsiders" and chaired by members of the central board, thus creating a direct link between them and the central board. In contrast to a system under which committees of the central board review activities in specialized areas, the mini-board approach would neither rely on "inside" corporate officials, who are subject to conflicting pressures, nor further overwhelm the already heavily burdened "outside" director. Rather, the board would be in effect replicating itself. In so doing, the board would be reducing its own "span of control," thereby gaining a heightened monitoring capacity. It also would be gaining a second information net, paralleling the formal channels of communication already in existence, which would provide the board with a potential means of checking the degree of distortion in the information reaching it through the normal channels. Additionally, such mini-boards might serve as an apprenticeship or proving ground for future outside directors. ${ }^{182}$ Finally,

182 A testing ground is a useful idea in its own right. Peter Drucker in particular has argued that contemporary boards are often staffed by competent executives of other corporations who have no additional time to spare. P. Drucker, supra note 1 , at 629 . In addition, mistakes are not corrected easily in this area, given the diplomatic problems inherent in firing a well-known business leader who has failed to perform. 
the additional expense created by such a system would not be too costly for a large public corporation. ${ }^{183}$

Several arguments in opposition to the mini-board proposal appear inevitable: (l) what would such a mini-board do besides "spy" on the divisional chief executive and his subordinates?; (2) would it not create an undesirable adversarial relationship?; and (3) why would it not be preferable just to rely on an expanded staff at the central board level to accomplish these same purposes? Answers to these questions dovetail. First, the mini-board clearly would not exercise any veto authority other than of a temporary nature, because such actions would hopelessly confuse the allocation of authority within the corporation and would conflict with the belief, strongly held among businessmen, that ultimate operational power must be centralized in one executive. ${ }^{184}$ Rather, while providing a Distant Early Warning System of board monitoring stations located throughout the corporation, the mini-board structure would also offer the divisional executive important positive incentives to counteract his probable early suspicion of it. First, the mini-board would perform at a lower level within the corporation the same function that is the principal activity of boards today: serving as a management consulting team for the chief

183 Assume that a hypothetical corporation has four major divisions, thus requiring four mini-boards. Assume further that each mini-board has five menibers, four of whom would be new "mini-directors," and the fifth a member of the senior board. If each of these 16 new directors received a salary of $\$ 10,000$ and the additional "staff" costs were $\$ 90,000$, the resulting figure of $\$ 250,000$ (at an assumed $50 \%$ corporate tax rate) would reduce net income to shareholders by $\$ 125,000$. This amount is less than $.5 \%$ of the net income of the smallest corporation (in terms of revenues) in the "Fortune 500." See ForTuNE, May, 1977 , at 384 (showing No. 500, Foxboro, to have had net income of $\$ 27,403,000$ ).

184 Although the necessity of a strong chief executive officer is an article of faith among American managers, it is not to their equally efficient Japanese counterparts, who stress instead collegial decisionmaking and sbared authority. Commenting upon the differences between the American practice of individual decisionmaking by virtue of one's office, and the Japanese policy of decisionmaking by consensus, one Japanese businessman has observed:

In America, decisions can be reached quickly because there is always a guy who is in charge of some affair. There is none in Japan. There is nobody in a Japanese company who is really "in charge" of anything-not even the president. We do not have any very clear concept of chief executive officer or chief operating officer.

Japanese Managers Tell How Their System Works, ForTune, November, 1977, at 126, 130 (comments of Yoshio Terasawa). For our purposes, the point here is that those who would assert that approaches such as the mini-board would impact severely upon corporate efficiency should bear the burden of proof in light of the Japanese experience. 
executive officer. ${ }^{185}$ Because the divisional chief executive is apt to be less experienced than his senior counterpart, such a consulting team composed of businessmen with practical experience may be a welcome resource to him. More importantly, the contemporary board also serves as a "buffer" for the chief executive, providing him with a "sheltered and supportive environment in which to function." ${ }^{186}$ When difficult decisions have to be made, there is always a desire in any organization to share and diffuse responsibility. But this is especially true at middle echelons within the corporate structure. When things go wrong, and senior management must inform the board where the blame lies, the most inviting scapegoat tends to be a distant divisional executive whom the board does not know.

Despite the popular mythology that difficult decisions always rise to the top, the best evidence is to the contrary: where uncertainty exists, the tendency is for difficult decisions to be delegated. ${ }^{187}$ The significance of this point is two-fold. First, it suggests that the middle-echelon corporate executive has perhaps the greater need for the buffer function that an advisory mini-board can perform. Second, if tough decisions frequently flow down, not up, in the corporate hierarchy, the senior board needs outposts within that structure if the corporate superego is to function on a prospective basis. In short, the mini-board proposal exemplifies the multiple functions that an effective auditing system could perform if properly structured. To the divisional executive, the mini-board would be a means by which he could both protect himself and communicate directly to the board when decisions made by him later seem incorrect. To the senior board, it would

185 For a concise summary of Mace's views in this regard, see Vagts, Directors: Myth and Reality, 31 Bus. LAw. 1227, 1229-30 (1976).

186 Heineman, What Does and Doesn't Go On in the Boardroom, ForTunE, February 1972 , at 157,159 , quoted in M. EISENBERG, supra note 12, at 158 .

187 Studying corporate decisionmaking, Professor Morris has summarized: "The greater the uncertainty that characterizes a decision, the greater the tendency for it to be delegated." W. MoRris, supra note 1, at 53. This tendency toward decision avoidance is also emphasized by others. See, e.g., 1. JANis \& L. MANN, supra note 29, at 6 . Decisions concerning social problems seem particularly apt to be ones that corporate decisionmakers might wish to avoid and delegate to subordinates. If so, the utility of the mini-board comes into focus as both a support system for the divisional executive, who may also wish to avoid such social decisions, and as a fail-safe sytem of communications for the senior board, who otherwise may never learn of such issues from management. 
provide a second network of communications that would be immune to the filtering efforts of senior management. To lowerechelon corporate personnel, it would provide a local corporate superego to which they could resort for discreet counsel about questionable corporate activities, without engaging in the high treason of "whistle blowing." 188

But why could not an expanded staff achieve the same results? The answer in part is that the mini-board's protection of the divisional chief executive is a function that staff cannot perform as well. But the full answer goes deeper. A second cardinal rule of communication theorists (the first being the tenet that the informant must trust the recipient for information flow to be efficient ${ }^{189}$ ) is that subordinates communicate sensitive information to superiors only when they perceive the supervisor to have the "capacity to exert influence upward." 190 Both of these tests-the "trust" criterion and the "clout" criterion-distinguish the mini-board from the junior officer likely to be assigned to staff duty. It is unrealistic to believe that a divisional chief executive would tolerate the same level of persistent inquiry from an employee who is far inferior to him in status, age, pay, and seniority that he would from a mini-board, populated by men who are at least his peers and chaired by a director of the senior board.

The linkage of the mini-board to the senior board through the interlocking presence of its chairman on both boards has a special theoretical significance. Considerable work has focused on comparative evaluations of different organizational configurations in terms of their effects on communication within the organization. Based on this work, Rensis Likert, Chairman of the Institute on

188 Consider again the position of Gulf's isolated bagman, Viglia. See notes 120-22 supra.

189 A Motivational Approach, supra note 164, at 190-92, 210-11.

190 Id. at 202. See also D. Katz, M. Maccoby, \& N. Morse, Productivity, Surervision and Morale in an Office Situation, pt. I (1950). Clearly, a mini-board on which a "senior" director serves has "clout."

This view, that effective monitoring requires the auditor to have "clout" or at least the capacity to pursue an in-depth investigation, has independent empirical support. The key, according to one such study, is that the auditor must be "perceived as having the power to go beneath the apparent evidence to determine what in fact happened." Churchill, Cooper, \& Sansbury, Laboratory and Field Studies on the Behavorial Effects of Audits, in Management Controls: New Directions in Basic Research 258 (C. Bonini, R. Jaedicke, H. Wagner eds. 1964). If so, monitoring is an activity that seems best performed by corporate officials of some seniority, not junior staff personnel temporarily attached to the board. 
Social Relations at the University of Michigan, has concluded that information blockages are least likely to occur when the supervision function is structured into the system through the use of "overlapping groups" linked by common members. ${ }^{191}$ Others have concurred with Likert's empirical findings, noting that communication within a working unit is fuller, faster and, most importantly, less vulnerable to the "motivation to deliberately bias information." ${ }^{192}$ Likert suggests that this improvement in the flow of information arises from two sources. One is the greater trust. that members of face-to-face groups have in one another. The other is the reduced communication distortion caused by the absence of serial transmission of information across hierarchical levels because the overlapping groups are connected by their common "linking pin" member. The mini-board would be so linked both to the senior board and to the divisional chief executive.

As noted earlier, the reverse side of the coin to the problem of information flow upward, is the problem of enforcing compliance downward ("authority leakage"). Here again, there are reasons for believing that a mini-board could outperform an expanded staff. Unlike a staff, the mini-board could do more than gather information. To a degree, it could bargain for compliance as the board's proxy, and, where necessary, credibly threaten sanctions. Conversely, proposals for expanding the board's staff in order to give it an auditing arm ${ }^{193}$ have been greeted with considerable skepticism, not only by businessmen, but also by some of the leading

191 A Motivational Approach, supra note 164, at 200-08. The critical element, according to Likert's research, is that there be a common member in both groups, a linking pin who as a recognized full member of each group will receive a fuller disclosure of sensitive information. At the same time, one "relay" in the sequential transmission of the information will be eliminated, thereby reducing "noise" in the terminology of the communications theorist. For a similar view expressed in terms of the economics of information sharing, see Arrow, supra note 174, at 216-20, 224-31.

102 W. MoRris, supra note 1 , at 50 .

103 The best known of these proposals was that made by Arthur J. Goldberg at the time of his resignation from the TWA board. Pointing out that the typical outside director could not "acquire more than a smattering of knowledge about any large and far flung company," he resigned because it was impossible for him to fulfill the policy making function he felt that corporate law imposed upon him. Goldberg, Debate on Outside Directors, N.Y. Times, Oct. 29, 1972, $\S 3$, at 1 , col. 2. The importance of this debate is underscored by Professor Burns' observation that those who control communications within the corporation hold the "basis ... of power within the corporate system." Burns, supra note 135, at 174. Approaches such as a staff system or a mini-board are thus attempts to break the monopoly over corporate communications held today by senior management. 
proponents of corporate reform. For example, Professor Eisenberg has criticized the best known of these proposals, that made by former Justice Goldberg, as "unsound and unworkable." $194 \mathrm{He}$ feels that any such "shadow staff" would have an "institutionalized obligation to second-guess the management, but very limited responsibility for results." ${ }^{195}$ Peter Drucker has sounded a similar theme. He feels that service staffs tend to be elitist and to have "contempt" for operating personnel, ${ }^{196}$ and that their advice is frequently tailored to "placate" the "powerful . . . barons" they serve. ${ }^{197}$ As a result, they tend not to cure, but rather to compound management weakness. ${ }^{198}$ Whatever the cogency of these criticisms, the point here is that the mini-board approach minimizes these dangers. By design, the mini-board would be positioned not to second-guess, but to participate prospectively, and so it would share some degree of responsibility for failure. Because it would have other functions besides information gathering, and because it would be composed of professional managers, its orientation towards management likely would be less elitist and more empathetic; in turn, the danger of resentment by management would be reduced as a result. Equally important, by creating mini-boards the board would create allies for itself and thus be able to play the power politics games that seem to characterize large organizations. ${ }^{199}$

194 M. EISENBERG, supra note 12 , at 155 .

195 Id. In part, Eisenberg is agreeing here with the position taken by Roger Blough, the former Chairman of U.S. Steel, in rebuttal to Goldberg. See Blough, The Outside Director at Work on the Board, 45 N.Y. ST. B.J. 467 (1973). Should a conflict arise between the board's staff and management, the directors are more likely to be exposed to liability for wrongly supporting management than if there were no staff, because they would to a degree be put on notice. Yet, in the long run, Blough argues they still generally will have to agree with the judgments of senior management, which is more experienced, and probably more talented, tban those on the staff.

196 P. DRUcker, supra note I, at 538 .

197 Id. at 583 .

198 Id. at 582, 625-26. Also skeptical of the Goldberg proposals is Courtney Brown, Dean Emeritus of the Columbia Business School, who warns that such board intervention as the Goldberg proposals contemplate can have a "debilitating" effect on management. C. Brown, supra note 9, at 32. In its recently issued Corporate Director's Guidebook, 32 Bus. LAw. 5, 37 (1976), the Subcommittee on Functions and Responsibilities of Directors of the ABA's Committee on Corporate Laws also has rejected the idea that the board should be equipped with any "regular outside staff."

199 Relying on earlier work of political scientist Richard Neustadt that focused on the "alliance politics" characterizing decisionmaking in bureaucracies, Professor Joseph Bower of the Harvard Business School has argued that the "process of planning in the large 
Finally, comparison is necessary with recent proposals for the adoption of the European system of a two-tier board structure. Under that system, a "senior" board of "outside" directors monitors the decisions of a "junior" board of inside directors. ${ }^{200}$ If our diagnosis is correct in emphasizing the problems of organizational distance and information flow, the deficiency of the two-tier approach is that it increases the organizational distance between the monitoring agency and the corporate infrastructure by superimposing a second "crow's nest" on top of the existing one. Essentially, the mini-board proposal is the mirror image of such a two-tier idea. Its central aim is to place the outsiders not in a higher "crow's nest," but closer to the locus of problems within the corporate structure.

In summary, a basic rule of management theory is that "structure follows strategy." ${ }^{201}$ At various times in the recent history of the business corporation, it has been a sound strategy either to centralize or to decentralize corporate structure, or to establish some mixed system, depending on the set of opportunities and hazards then confronting the corporation. Today, as the era of dynamic business growth may have faded, and a new era has dawned

organization is tied closely to its social and political life." Corporate officials respond to plans and policies depending on the potential impact on their careers. Within this context, corporate planning "is an argument for something a network of managers wants to do because it will be in their interest to do so." Bower, supra note 13, at 195-96. To the extent that subordinates find their self-interest "aligned" with that of the board of directors through mediating devices such as the mini-board, the senior board acquires allies and participates more effectively in planning. To give a practical example suggested by Bower, clean air is a worthy corporate objective, but it will not be pursued by middlelevel managers unless they are forgiven the high costs and lower profit margins that result. $I d$. at 197 . The process of changing the standards of measurement by which such managers are judged, so that they will see their self-interest aligned with the board's perception of the best overall corporate policy, is one in which the senior board as the corporate superego needs allies such as the mini-board. Otherwise, although senior management often will espouse worthy goals in public utterances, it still may hold the middle-level corporate manager accountable for his lower profit margin incurred in pursuit of the board's non-profit-maximizing goals. Top management long ago "learned to shape the game of careers so that its stakes correspond to the econounic goals of the firm." Id. at 210. I would add that it is therefore necessary for those who would represent the conscience of the firm to learn the rules of this game also.

200 See M. EISENBERG, supra note 12, at $177-85$ for a critical summary of these proposals. Under the German model, the managing board, or "Vorstand," is composed solely of the corporation's inside top executives. It is overseen by a supervisory board, or "Aufsichtsrat," which does not include any members of the managing board. See also Vagts, Reforming the "Modern" Corporation: Perspectives from the German, 80 Harv. L. Rev. 23 (1966).

201 P. DRUCKER, supra note 1, at 523. 
in which major business opportunities increasingly are surrounded by hidden costs and risks, it may be a sound strategy to enhance the capabilities of the corporate superego to make the corporation, if not more risk averse, at least more risk conscious. Such a strategy requires changes in corporate structure. Unfortunately, however, because most commentators on corporate law have focused on the normative aspects of corporate behavior rather than on the empirical, the remedies currently suggested seem inadequate at best. The most common suggestions, involving reliance on a true "outside" board or an expanded staff, do not address the central problem of information blockages.

To be sure, the suggested mini-board approach is untested, unorthodox, and, given the glacial pace of corporate reform, unlikely to be adopted early. Its chief utility in the short run is not as an answer in itself, but as a paradigm by which to illustrate a different way of approaching corporate law problems. ${ }^{202}$ Rather than pursue its specifics further, it seems better to exanine next what resources the law now possesses to encourage a redesign of corporate structure and information flow in order to achieve at least marginally improved results.

\section{Toward a Legal View: Surveying the CONTEMPORARY LEgaL TERRAIN}

Reform, of course, must begin with the materials at hand. New legal principles evolve from old ones. But, because legal doctrines are not infinitely malleable, it is important to determine exactly the limits of the courts' discretion. Once we have scouted the perimeters of judicial flexibility in the area of improper corporate activity, we can return to the linked questions of (a) what considerations should guide courts in exercising their discretion, and (b) what results can such a common-law approach obtain? Using the "improper payments" controversy as a microcosm in which to approach more general issues of corporate reform, this section will assess the substantive positions of a plaintiff and a defendant in a typical derivative suit commenced to challenge improper payments. The "improper payments" controversy is used because one of its most useful and representative features is the degree to which

202 For an earlier attempt to approach some corporate law problems from a behavioral standpoint, see Conard, supra note 1 . 
it demonstrates that "misconduct" and "illegality" are not synonymous terms. ${ }^{203}$

\section{A. A Cook's Tour of Commercial Bribery}

Four types of existing statutory provisions arguably apply to improper payments: (1) criminal statutes, (2) antitrust statutes, (3) tax laws, and (4) securities laws. ${ }^{204}$ Although criminal statutes clearly proscribe bribery of governmental agents, as a general rule they only tangentially and indirectly prohibit commercial bribery. Only half of the states have enacted statutes broadly aimed at commercial bribery, ${ }^{205}$ and still fewer enforce them. ${ }^{200}$ Even when enforcing such laws, courts have restrictively read them not to cover "defensive" payments. ${ }^{207}$ On the federal level, several criminal statutes arguably could be stretched to cover commercial bribery, ${ }^{208}$ potentially including even extraterritorial acts and un-

203 The time has come to abandon the luxury of vaguely referring to "improper payments" as if that term had recognized legal connotations. It does not. The penetration of criminal statutes into this area has been uneven, uncertain, and limited. See notes 205-45 infra and accompanying text. It is submitted that this is characteristic of many types of business behavior that today fall under the heading of "corporate misconduct."

204 In addition, when the corporation making the payments is witbin a regulated industry, the federal agency supervising that industry probably also has jurisdiction (particularly if the payment in effect was passed on to the public or the government). For a summary of the responses of some regulatory agencies in this area, see Herlihy \& Levine, supra note 2, at 599-611. See also Federal Alcohol Administration Act $\S 205$ (c), 27 U.S.C. $\$ 202$ (1970); Shipping Act, $1916 \S \S 16-18$, 46 U.S.C. $\$ \S 815-817$ (1970); Interstate Commerce Act $\$ 1(17)(b), 49$ U.S.C. $\$ 1(17)(b)$ (1970).

205 A survey made in connection with an ALI-ABA conference on this subject in May, 1977 shows that 25 states have statutes covering commercial bribery. See Ferrara \& Williams, Saints and Sinners Revisited, supra note 65, at 139-47. More common are statutes aimed at bribery of labor officials, bribery in connection with athletic contests, and other narrowly focused targets.

200 In Conway Import Co. v. United States, 311 F. Supp. 5 (E.D.N.Y. 1969), Judge Orrin Judd described Pennsylvania's statute against commercial bribery as "in a state of innocent desuetude . . . with no record of any conviction for violation of the law." Id. at I6.

207 For decisions limiting the reach of such statutes, see Savoy Laundry \& Linen Supply, Inc. v. Morgan Linen Serv., Inc., 16 Conn. Supp. 408 (Super. Ct. 1949); Shemin v. A. Black \&. Co., 19 App. Div. 2d 596, 240 N.Y.S.2d 622 (1963) (statute must be strictly construed). Cf. Lilly v. Commissioner, 343 U.S. 90 (1952) (deduction for kickbacks allowed). The theory for the restrictive reading is that the legislature did not intend to require the potential victim of extortion to resist heroically. See Hornstein v. Paramount Pictures, Inc., 22 Misc. 2d 996, 37 N.Y.S.2d 404 (Sup. Ct. 1942), aff'd mem., 266 App. Div. 659, 4 I N.Y.S.2d 210, aff'd per curiam, 292 N.Y. 468, 55 N.E. 740 (1944) (discussed at note 374 infra).

208 The federal mail fraud statute, 18 U.S.C. $\$ 1341$ (1970), and the federal wire fraud statute, 18 US.C. $\S 1343$ (1970), are the two most likely candidates, and their 
consummated conspiracies. ${ }^{200}$ Because these laws require a "scheme or artifice to defraud," ${ }^{210}$ however, they probably fall short of reaching most "defensive" or "grease" payments. Additionally, there is some indication that courts will tend to read these statutes narrowly as not applying to the "regulatory" crime of commercial bribery. ${ }^{21}$

The antitrust laws also may bar some improper corporate payments. ${ }^{212}$ The most likely violations are of section 5 of the Federal

reach can be extended by the federal conspiracy statute, 18 U.S.C. $\$ 371$ (1970), if there exists a conspiracy to violate either statute. A wealth of case law indicates that these statutes use a broad, "nontechnical" definition of fraud. See United States v. George, 477 F.2d 508 (7th Cir.), cert. denied, 414 U.S. 827 (1973); Blachly v. United States, 380 F.2d 665, 671 (5th Cir. 1967) ("Law puts its imprimatur on the accepted moral standards and condemns conduct which fails to match the reflection of moral uprightness of fundamental honesty, fair play and right dealing in the general and business life of members of society."); United States v. Groves, 122 F.2d 87 (2d Cir.), cert. denied, 314 U.S. 670 (1941) (a fiduciary who withholds relevant information from his principal may be so prosecuted); Shushan v. United States, 117 F.2d 110 (5th Cir.), cert. denied, 313 U.S. 574 (1941). If certain governmental contracts are involved, the Anti-Kickback Act, 41 U.S.C. $\$ \$ 51-54$ (1970), may also be violated. Finally, there is divided authority as to whether the Interstate and Foreign Travel or Transportation in Aid of Racketeering Enterprises Act, 18 U.S.C. $\S 1952$ (1970), reaches such conduct. See note 211 infra. While no current federal statute specifically prohibits commercial bribery, the pending recodification of the federal penal code would do so. See S. 1437, 95th Cong., Ist Sess. § 1751 (1977).

209 Because the federal wire fraud statute expressly refers to "foreign commerce" and the federal mail fraud statute in theory creates a crime against the mails, the usual rules against extraterritorial application of penal statutes should not apply if the bribery scheme is effected through methods over which there is the requisite jurisdiction. See Pereira v. United States, 347 U.S. 1 (1954) (interbank transfer by mail of fraudulently obtained check held sufficient for jurisdictional purposes).

210 Such language is present in both the federal mail and wire fraud statutes. See 18 U.S.C. $\$ \S 1341,1343(1970)$. It suggests that a line will have to be drawn between active bribery and passive acquiescence to extortion.

211 At present, the Second and the Fourth Circuits disagree over whether commercial bribery in violation of state law can also fall within the coverage of 18 U.S.C. $\$ 1952$ (1970), which prohibits interstate travel to promote bribery. Compare United States v. Pomponio, 511 F.2d 953 (4th Cir. 1975) (holding that the statute applies), cert. denied, 423 U.S. 874 (1976), with United States v. Brecht, 540 F.2d 45 (2d Cir. 1976), cert. denied, 429 U.S. 1123 (1977), and United States v. Niedelman, 356 F. Supp. 979 (S.D.N.Y. 1973) (both holding that the statute does not apply). In concluding that the federal statute had not been violated, the Second Circuit in Brecht distinguished between the "traditional" crime of bribery and the "modern crime of commercial bribery," and expressed doubt that Congress had intended to reach the latter. 540 F.2d at 48-50. Despite these and other technical problems, a federal task force is currently presenting criminal cases to grand juries around the country with respect to corporate payoffs, both foreign and domestic. See Berry, Payoff Charges Pushed, Wash. Post, Apr. 16, 1977, at C9, col. 6.

212 For a thorough examination of how the antitrust laws may apply to improper corporate payments abroad, see McManis, Questionable Corporate Payments Abroad: An Antitrust Approach, 86 YALE L.J. 215 (1976). 
Trade Commission Act, which prohibits "unfair methods of competition," 213 and, even more promising, section 2(c) of the Robinson-Patman Act, ${ }^{214}$ which prohibits any person engaged in commerce from paying any "commission, brokerage or other compensation" to the "other party" to a transaction or to its agent. ${ }^{215}$ Although the legislative intent of this latter section clearly aimed at a different evil (price discrimination via the practice of large buyers exacting price concessions unavailable to smaller buyers), existing precedent suggests a broad, if untested, theory under which section 2(c) might apply at least to "aggressive" payments. If so, the Act's scope would be far-reaching, because the section (1) requires no proof of anticompetitive effect, ${ }^{216}$ (2) has sufficient extraterritorial application to cover export sales, ${ }^{217}$ (3) is not subject to the principal Robinson-Patman defense that the payor firm was only seeking to meet the competition, ${ }^{218}$ and (4) apparently applies even when the agent receiving the side payment in effect is defrauding his own principal rather than passing the payment on as an illicit price concession. ${ }^{219}$ However, once again there are significant qualifications to the statute's comprehensiveness. ${ }^{220}$

The Internal Revenue Code in particular represents a congressional attempt to draw fine lines in the area of improper corpo-

21315 U.S.C. $\S 45(\mathrm{a})(1)$ (1970). In theory, the Sherman Act, 15 U.S.C. $\$ \S 1-7$ (1970), may also apply, but practical problems may inhibit such an approach. Herlihy \& Levine, supra note 2 , at $604-05$.

21415 U.S.C. $\S 13(c)$ (1970).

215 Id.

216 See FTC v. Henry Broch \& Co., 363 U.S. 166 (1961); Oliver Bros. v. FTC, 102 F.2d 763 (4th Cir. 1939).

217 See Canadian Ingersoll-Rand Co. v. D. Loveman \& Sons, 227 F. Supp. 829 (N.D. Ohio 1964); Baysoy v. Jessop Steel Co., 90 F. Supp. 303 (W.D. Pa. 1950).

218 This "meeting the competition" defense, which appears in the proviso in section 2(b) of the Act, applies only to the section 2(a) offense of price discrimination and not to the section 2(c) offense. See FTC v. Washington Fish \& Oyster Co., 282 F.2d 595 (9th Cir. $1960) ; 15$ U.S.C. $\$ 13(a)-(c)$ (1970).

219 See Fitch v. Kentucky-Tennessee Light \& Power Co., 136 F.2d 12 (6th Cir. 1943).

220 Besides the formidable problems of proof that exist where the payment is made indirectly, and allegedly without the corporation's knowledge or permission (as through a middleman such as a Khashoggi), there are also cases holding that the statute is not applicable to sales to governmental units. See General Shale Prods. Corp. v. Struck Constr. Co., 37 F. Supp. 598, 602-03 (W.D. Ky. 1941), aff'd, 132 F.2d 425 (6th Cir. 1942), cert. denied, 318 U.S. 780 (1943). But see Rangen, Inc. v. Sterling Nelson \& Sons, 351 F.2d 851, 858-59 (9th Cir. 1965), cert. denied, 383 U.S. 936 (1966). In addition, the Robinson-Patman Act applies only to sales of "commodities," so section 2(c) may not apply to service or consulting contracts. E.g., Tri-State Broadcasting Co. v. United Press Int'l, Inc., 369 F.2d 268 (5th Cir. 1966). 
rate payments. Section 162(c) denies business expense deductions for bribes to foreign and domestic government officials, and for domestic bribes that are illegal under a generally enforced local law. ${ }^{221}$ However, as with Sherlock Holmes's dog that did not bark in the night, the most striking feature of the Code is what Congress did not do. Even in the Tax Reform Act of 1976, ${ }^{222}$ it declined to deny deductions for all overseas commercial bribes, as it did for similar domestic payments. Rather, by their deliberately piecemeal approach to the area, the tax laws seem in several respects to reveal a degree of tacit acceptance by Congress of such practices. ${ }^{223}$

This hesitant caution on the part of the legislature sharply contrasts with the bolder moralism of the SEC. Although the SEC has obtained a host of recent consent orders enjoining companies from

221 The Technical Amendments Act of 1958 added subsection (c) to section 162 of the Internal Revenue Code of 1954, which denied deductions for payments otherwise qualifying as ordinary and necessary if such payments were made to an official or employee of a foreign government and would have violated United States law if it had applied. Technical Amendments Act of 1958, Pub. L. No. 85-866, tit. I, $\S 5,72$ Stat. 1606 (1958). The Tax Reform Act of 1969 then split the subsection into two parts: $\$ 162(c)(1)$, covering payments to governmental officials, and $\S 162(\mathrm{c})(2)$, covering bribes and kickbacks to nongovernmental employees if the taxpayer has been convicted of making such an illegal payment. Tax Reform Act of 1969, Pub. L. No. 91-172, tit. IX, $\$ \S 902(c)(1), 902(c)(2), 83$ Stat. 487 (1969). In 1971, Congress deleted this conviction requirement in subsection (c)(2), and substituted a requirement that the payment be unlawful under a generally enforced local law providing for criminal penalties or certain civil forfeitures. I.R.C. $\$ 162$ (c). In addition, the IRS has denied deductions for payments that violate public policy. See Tank Truck Rentals, Inc. v. Commissioner, 356 U.S. 30 (1958). But on more than one occasion, courts have refused to find that commercial bribes violate any federal public policy. See Lilly v. Commissioner, 343 U.S. 90 (1952); Conway Imports Co. v. United States, 311 F. Supp. 5 (E.D.N.Y. 1969).

222 The Tax Reform Act of 1976, Pub. L. No. 94-455, 90 Stat. 1520 (1976), added highly technical provisions revising the definition of Subpart $F$ income of controlled foreign corporations, I.R.C. $\$$ 952(a)(4), and deeming certain payments by Domestic International Sales Corporations as taxable dividends to their parents, I.R.C. $\$ 995(\mathrm{~b})(\mathrm{I})(\mathrm{F})(\mathrm{iii})$. While these provisions will further inhibit questionable payments somewhat, Congress failed in 1976, at the height of the improper payments controversy, to tighten section 162 (c) to comprehensively deny deductions to all such payments. Rather, that section continues to make narrow distinctions between categories of payments.

223 This hairsplitting approach is evidenced in two distinct ways. First, the deductibility of foreign payments to nongovernment officials and employees (i.e. commercial bribes) is not conditioned on their vicarious status under United States law, as is section 162(c)(1) with respect to governmental bribes. Second, the status of domestic commercial bribes is made to depend on whether the local statute is generally enforced. For a general overview, see Alfred, Corporate Slush Funds: The Deductibility of "Sensitive" Payments, 4 J. CoRP. TAX. 130 (1977). 
making payments for "unlawful purposes," ${ }^{24}$ the narrowness of the legislative proscriptions in this area calls into question whether these consent orders actually reach the "defensive" or "grease" payments that led up to these settlements. ${ }^{225}$ Ironical as this may be, there is also a larger significance here: from a traditional civil libertarian point of view, is it desirable to subject corporate officials to the in terrorem threat of criminal contempt where the legal standards that actually govern remain ambiguous and the negotiated injunction seems almost deliberately vague at its margins? Given also the axiomatic reluctance of courts to expand penal statutes by inference, it then becomes important to inquire whether there are superior options available to courts on the level of civil liability, particularly in those troubling cases where we are willing to describe the behavior involved as "corporate misconduct" but nonetheless recognize that it only partially overlaps with conduct that the legislature has clearly proscribed.

\section{B. The Plaintiff's Case: Taking Inventory of the Theories Available}

The theories that a plaintiff might assert in a derivative suit attacking improper payments can be grouped under three basic headings: (1) strict liability theories, (2) negligence-based theories of liability, and (3) the somewhat nebulous but not unprecedented theory that the corporation and its officials may not act in violation of public policy.

224 For a synopsis of many of the major recent consent orders, see Ferrara \& Brandon, supra note 39 , at 693-794 (summarizing the terms of 19 recent settlements). A prohibition against use of corporate funds for "unlawful purposes" appears to have become a standard part of the final Judgment of Permanent Injunction. It is possible that defense attorneys agree to this language because they believe that it prohibits less than a detailed description of activities would.

225 This analysis of the legality of improper payments omits any discussion of the federal securities laws. To the extent applicable, the securities laws would penalize not the payments themselves, but their nondisclosure. This topic deliberately has been postponed until the end of the article. Amendments to the Securities Exchange Act of I934 passed by Congress in December 1977 will hereafter require most public corporations to maintain "accurate and fair books and records," thus preventing the use of off-book slush funds established to pay bribes. See note 65 supra, note 595 infra. Again, however, legislative caution appears evident in the careful exemption of grease and nongovernmental payments, see note 65 supra, and in the exemption requested by the State Department of foreign subsidiaries of U.S. corporations from the Act's coverage. See Corporate Bribery Bill Is Approved, Wash. Post, Dec. 8, 1977, at D1, col 6. For a description of the obstacles facing a private litigant seeking to attack such payments under these laws, see note 581 infra. 


\section{Theories of Strict Liability}

By "strict liability," I mean a theory of liability that permits no affirmative defense (with the result that claims of due diligence, good faith, or the lack of a net loss, even if provable, would not avoid liability). Three such theories find some support in the case law: (1) the doctrine of negligence per se, (2) the ultra vires doctrine, and (3) the apparent rule that an actor is strictly liable for a "knowing" violation of law.

\section{a. Negligence Per Se}

In tort law, the defendant motorist who fails to stop at the stop sign generally receives no opportunity to show that his conduct was reasonable under the circumstances. Violation of the governing ordinance itself is negligence, because courts presume that the legislature intended to replace the normal "prudent man" test of negligence with a more specific, "bright line" standard of liability. ${ }^{226}$ However, the notion that the specific content of applicable statutes and regulations invariably supersedes the more generalized standard of reasonable care has become increasingly disfavored. At least three major limitations now appear to limit the negligence per se doctrine: (l) the requirement that the plaintiff show that he is within the class intended to be protected by the statute, ${ }^{227}$ (2) the emerging tort doctrine that some statutory violations may be excused or justified, ${ }^{228}$ and (3) the conflict of laws limitations that potentially arise in the context of multi-jurisdictional transactions. ${ }^{229}$ Each of these may have significant exculpatory effect in the context of corporate misconduct.

226 F. Harper \& F. James, The Law of Torts $\$ 17.6$, at $997-98$ (2d ed. 1970).

227 Id. $\$ 17.5$, at $989-91, \S 17.6$, at 1003-05. Section 286 of the Restatement (Second) of Torts now states that the court "may" adopt a legislative enactment as the standard of conduct of a reasonable man, if the purpose of such enactment includes the protection of "a class of persons which includes the one whose interest is invaded ..."." RESTATEMENT (SECOND) OF TORTS $\$ 286$ (1965). See also id. $\$ 288$.

228 F. HARPER \& F. JAMEs, supra note $226, \S 17.6$, at 1008-11. The authors summarize: "In most jurisdictions, however, the negligence per se rule is administered so as to permit consideration of some factors of excuse." Id. at 1008. See also Restatement (SECOND) OF ToRTS $\S 288 \mathrm{~A}$ (1965).

229 In part, these limitations grow out of the conflicts of law principle that one jurisdiction will not "enforce" the penal laws of another. See Restatement (SECOND) of Confuct of LAws $\$ 89$ (1971). This principle has led some courts to refuse to enforce foreign corporate statutes expressly imposing civil liability on directors for specified acts, where the court's enforcement of the statute would be tantamount to imposing a foreign penal 
In the context of derivative suit litigation, courts have only infrequently analyzed the first precondition, that the plaintiff be within the statute's protected class. However, where they have analyzed it, they have accepted it. In the Second Circuit, Judge Lumbard, in a concurring opinion in Spirt $v$. Bechtel ${ }^{230}$ that constituted one-half of the majority in a $2-1$ decision, found no intent to protect shareholders in a statute restricting the amount of compensation payable to executives of a regulated shipping corporation, although clearly any statute limiting executive compensation will have at least the incidental effect of increasing the income available for dividends. Rather, the main purpose of the statute, as he saw it, was to prevent misapplication of a governmental subsidy that the corporation was receiving. Because of this, Judge Lumbard concluded that the statute was not "meant to be a measure of the obligation of the defendants to the company," ${ }^{231}$ and thus its violation did not make the defendants strictly liable to the company. A more recent case, Miller $v$. AT $\dot{\omega} T,{ }^{232}$ can be read to conform with this approach, although it seems at first glance to impose strict liability in sweeping terms. In Miller, the defendant

sanction. See, e.g., Arcouet v. Papp, 21 Misc. 2d 294, 190 N.Y.S.2d 549 (Sup. Ct. 1959); Paper Prods. Co. v. Doggrell, 195 Tenn. 581, 261 S.W.2d 127 (1953). See also ResTATEMENT (SECOND) OF Conflict OF LAws $\$ 89$, Reporter's Note c (1971).

Moreover, the underlying premise of the negligence per se doctrine, that a court must defer to the legislature's attempt at defining the standard of conduct of the reasonable man, seems weaker when the court and the statute violated are from different jurisdictions. In such circumstances, although the violation will probably be seen as "evidence of negligence," a state court understandably may apply its own common-law standards.

230232 F.2d 241 (2d Cir. 1956).

231 Id. at 248. Citing section 286 of the Restatement (Second) of Torts, Judge Lumbard concluded that the statute was not intended to protect the plaintiff. Id. at 250. But see 232 F.2d at 252-53 (Frank, J., dissenting). A more recent case, Schwartz v. Romnes, 495 F.2d 844 (2d Cir. 1974) also has raised this issue, hinting that it could bar a plaintiff stockholder. There, the state statute prohibited corporate contributions "for political purposes." Applying an exceedingly narrow construction to find that the statute had not been violated, the Second Circuit noted that it therefore became "unnecessary to decide whether, assuming a violation, a private derivative action may be implied in favor of plaintiff." 495 F.2d at 854 .

Earlier cases have held that sections of the National Bank Act, 12 U.S.C. $\$ \S 93,503$ (1970), that prohibit loans when the lending institution's capital is impaired are intended only to protect the Federal Reserve System and not the stockholders. See Holman v. Cross, 75 F.2d 909 (6th Cir. 1935); Allen v, Luke, I63 F. 1018 (D. Mass. 1908). If this strained statutory construction is accepted, the basic logic of the cases thereafter seems consistent with section 286 of the Restatement. See note 227 supra.

232507 F.2d 759 (3d Cir. 1974). 
directors were alleged to have violated a statute prohibiting corporate political contributions. The Supreme Court previously had concluded that Congress intended the statute's predecessor to protect shareholders from unauthorized use of corporate funds for the benefit of political parties. ${ }^{233}$ Against this backdrop, the Third Gircuit's finding that the plaintiff shareholder was within the "class for whose protection the statute was enacted" ${ }^{234}$ can thus be seen as a logical and necessary precondition to its statement in the same paragraph of the decision that it would not accept any "business judgment" defense from the defendant directors that the alleged payment was in the corporation's best interests. ${ }^{235}$ Viewed in this light, the Miller decision comes into focus as a classic application of the negligence per se doctrine.

Additional evidence that the protected class requirement is a necessary precondition to the imposition of strict liability is discernible in a common denominator underlying those cases holding directors strictly liable for violation of a statute: almost uniformly, they have involved statutes clearly intended to protect shareholders. In general, the statutes involved have been those limiting either the corporation's lending or borrowing capacity or the directors' ability to alter the capital structure of the corporation (such as by paying dividends or causing a corporate liquidation or stock redemption).${ }^{236}$ Although many of these decisions do not discuss the

233 United States v. CIO, 335 U.S. I06 (1948). See also Miller v. AT\&T, 507 F.2d 759, 763 (3d Cir. 1974).

234507 F.2d at 763.

$235 I d$. In the same paragraph as its conclusion that the statute was intended to protect shareholders, the Third Circuit added: "Under such circumstances, the directors cannot be insulated from hability on the ground that the contribution was made in the exercise of sound business judgment." Id. (emphasis added).

236 Several New York cases have held directors strictly liable for losses sustained by their corporations as a result of violations that the courts treated as "knowing" transgressions. Typically, the statutes violated directly regulated the financial institutions that the director served, such as by establishing lending or borrowing limits for banks or insurance companies. See Van Schaick v. Carr, 170 Misc. 539, I0 N.YS.2d 567 (Sup. Ct. 1938); Broderick v. Marcus, I52 Misc. 4I3, 272 N.Y.S. 455 (Sup. Ct. 1934). Despite these decisions' strong language that directors are strictly liable for statutory violations that they should have recognized, the cases seem consistent on their facts with the limitations on the negligence per se doctrine discussed in the text, because the legislature presumably intended to protect both depositors and stockholders of such institutions from assumption of unreasonable risks by management. Cf. Thompson v. Greeley, 167 Mo. 577, 117 S.W. 962 (I89I) (bank directors liable to bank or its receiver for loss due to loan given in violation of statute). It should be emphasized at this point that we are not discussing the director's liability for negligence, but only the question of whether he is per se liable. 
protected class requirement, it is still implicit in the context of the cases.

Given the protected class requirement, which of those statutes mentioned earlier as applicable to improper payments include shareholders within their protected class? The answer appears to be relatively few. For example, a general consensus seems to exist that the purpose of the antitrust laws is to protect a competitive economy. ${ }^{237}$ Thus, courts have denied relief to stockholders of the corporation injured by an antitrust violation on the grounds that they were not within the "target area" protected by the antitrust laws. ${ }^{238}$ The intended scope of protection of criminal bribery statutes would only rarely encompass shareholders of the corporate perpetrator. But, two types of relevant criminal statutes do seem intended to protect shareholders: (1) statutes against political contributions (although the legislative gloss given by Miller has since been clouded by a subsequent Supreme Court case), ${ }^{239}$ and (2) disclosure statutes, a class that includes several recurring forms of state legislation ${ }^{240}$ as well as the federal securities laws.

A second limitation on the negligence per se doctrine is the concept of "excusable" violations. Although the only legally sufficient excuse recognized by early cases was impossibility, more modern cases have expanded the doctrine to provide a variety of excuses..$^{241}$ Those having obvious relevance to the improper payments area include the prevalence of official nonenforcement, the fact of customary breach, the existence of a sudden emergency, and the reasonableness of the per se standard as applied to the particular case. Courts on occasion have recognized each of these as excusing

237 Brown Shoe Co. v. United States, 370 U.S. 294, 320 (1962).

23S Bookout v. Schine Chain Theatres, 253 F2d 292 (2d Cir. 1958). But see Karseal Corp. v. Richfield Oil Corp., 221 F.2d 358 (9th Cir. 1955). See also Comment, Federal Antitrust Law-Stockholders' Remedies for Corporate Injury Resulting from Antitrust Violations: Derivative Antitrust Suit and Fiduciary Duty Action, 59 MrcH. L. REv. 904, 912-29 (196l).

239 See Cort. v. Ash, 422 U.S. 66, 82 (1975) (noting that the statute was not "directly" concerned with "the internal relations between the corporation and their stockholders").

240 State penal laws often forbid falsifying corporate books and records and issuing false financial statements. See, e.g., N.Y. Penal Law $\S \S 175.00, .05, .10, .45$ (McKinney 1975).

241 F. HARPER \& F. JAMES, supra note 226, $\S 17.6$, at 1009-11 (noting a "perceptible trend" in a number of states toward "an expansion of the 'justifiable violation' doctrine under the negligence per se rule"). 
tort liability for violations of penal statutes. ${ }^{242}$ The Restatement (Second) of Torts now provides that violations may be excused when, inter alia, (1) the actor "is confronted by an emergency not due to his own misconduct," 243 or (2) "compliance would involve a greater risk of harm to the actor or to others." ${ }^{244}$ Returning to the case of the Gulf Oil executive confronted by a demand from South Korean officials for an immediate multimillion dollar "contribution," it appears then that, if refusal will jeopardize the corporation's far greater investment in that country, both the "alternative hazard" and "emergency" excuses have at least plausible relevance. ${ }^{245}$

\section{b. Ultra Vires}

The ultra vires doctrine provides the basis for a two-pronged attack by a plaintiff. First, officers and directors may be accountable for losses resulting from actions that exceed the powers of the corporation. ${ }^{246}$ Second, they may be held liable for losses resulting from actions within the corporation's authority, but beyond the scope of the powers delegated to them as agents. ${ }^{247} \mathrm{Be}-$ cause both approaches shift the inquiry away from the tort issues

242 Id. See also Jenkins v. Gity of Ft. Wayne, 139 Ind. App. I, 7, 210 N.E.2d 390, 394 (1965); Restatement (SECOND) OF TORTs $\$ 288$ A (1965).

243 RESTATEMENT (SECOND) OF TORTS $§ 288 \mathrm{~A}(2)$ (d) (1965).

$244 I d$. $\$ 288 \mathrm{~A}(2)(\mathrm{e})$.

245 To be sure, it is unlikely that the draftsmen of section $288 \mathrm{~A}$ contemplated either the specific context of the liability of corporate officials or the assertion of economic "harm" as a justification. Nevertheless, long before this revision of the Restatement, the case Jaw dealing with directors' duties contained suggestions that some emergency circumstances could excuse conduct by corporate officials that would otherwise be tortious and illegal. See, e.g., Hornstein v. Paramount Pictures, Inc., 22 Misc. 2d 996, 37 N.Y.S.2d 404 (Sup. Ct. 1942), aff'd mem., 266 App. Div. 659, 41 N.Y.S.2d 210, aff'd per curiam, 292 N.Y. 468,55 N.E. 740 (1944).

246 See W. Fletcher, Cyclopedia of the Law of Private Corporations $\$ \$ 1021-1028$ (rev. perm. ed. 1974); H. HeNN, HaNdBooK OF THE LAW OF CoRporations and OthFr BusiNESS ENTERPRISES $§ 233$, at 453 (2d ed. 1970). Commentators dispute whether corporate acts violating a statute should be classified as ultra vires or considered as a separate special category. Compare W. Cary, Cases and Materials on Corborations 52-53 (4th ed. 1969), with W. FLETCHER, supra, $\S 1024$, at $580-81$, and H. HF.NN, supra, $\S 233$, at 453 . The next section of this article considers those cases that seem to have considered statutory violations as a separate category.

247 One commentator has attempted to apply the distinction between the corporation's inherent lack of authority ("ultra vires authority") and its officers" lack of authorization ("ultra vires agency") to one area of "corporate misconduct." Note, Corporate Democracy and the Corporate Political Contribution, 61 IowA L. Rev. 545, 568-76 (1975). 
of causation and breach of a standard of care, and toward the agency law issue of authority, they offer the prospective plaintiff distinct doctrinal advantages. Perhaps most important, the "protected class" limitation is inapplicable. Further, some cases suggest that the agent has no defense based on his use of reasonable care in engaging in the unauthorized acts. ${ }^{248}$ Finally, the doctrine may enable the plaintiff to hold corporate officials liable for acts that, although not in violation of any statute, nonetheless strike the court as improper.

Early corporate cases applied the ultra vires doctrine aggressively, holding, for example, corporate officials strictly liable for political contributions not prohibited by any statute. ${ }^{249}$ The classic example of such an application to "improper conduct" is Roth v. Robertson, ${ }^{250}$ a 1909 New York decision with obvious relevance to the current payments controversy. In Roth, the manager of an amusement park, which operated in violation of a Sunday closing law, paid "hush money" to protect the corporation's illicit Sunday operations. The court held him strictly liable to the corporation because the illicit payments were ultra vires, notwithstanding the absence of self-dealing and the likelihood that the payments increased the corporation's profits. Any other result, the court said emphatically, would sanction clear violations of public policy. ${ }^{251}$

Roth, however, may represent a high-water mark of judicial activism, from which the tide of judicial opinion since has receded. A combination of two trends in the case law appears to have eclipsed its significance. First, the rule of strict liability for ultra vires acts increasingly has given way to a standard that holds the agent liable only when he negligently has exceeded his powers. ${ }^{252}$ More importantly, courts have developed and expanded an antithetical doctrine-that of implied powers-so that today it is axiomatic that corporations possess sufficient powers to "do all things reasonably necessary to enable the corporation to carry out its

\footnotetext{
248 See H. HENN, supra note $246, \S 233$, at $453 \&$ n.3. The modern approach, however, appears to hold the agent liable only when he is negligent as to the scope of his powers. 249 McConnell v. Combination Mining \& Milling Co., 30 Mont. 239, 254-55, 76 P. 194, 199 (1904), aff'd on rehearing, 31 Mont. 563, 79 P. 248 (1905).

25064 Misc. 343,118 N.Y.S. 351 (Sup. Ct. 1909).

251 Id. at 346, 118 N.Y.S. at 353 (discussed in text accompanying note 352 infra).

252 Litwin v. Allen, 25 N.Y.S.2d 667, 678 (Sup. Ct. 1940); see Sutton v. Reagan \& Gee, 405 S.W.2d 828, 836 (Tex. 1966).
} 
purposes . . ." ${ }^{253}$ With the advent of liberal construction of corporate charters, the modern test (at least for commercially motivated transactions) turns on the concept of "direct benefit." 254 In general, an act is not ultra vires if reasonably related to some expected benefit to the corporation.

Nonetheless, the Roth doctrine retained some viability over the years, and even into this decade uncertainty surrounded the issue of corporate authority to make political contributions where not prohibited by statute. ${ }^{255}$ However, several recent cases indicate that courts will follow roughly the same "direct benefit" guidelines in dealing with political contributions as with more traditional commercial transactions. In Schwartz $v$. Romnes, ${ }^{256}$ the Second Circuit considered the contribution by a telephone company to a committee supporting a statewide transportation bond referendum. After finding that the contribution did not violate New York statutes, the court turned to the plaintiff's ultra vires attack, which was based on a New York precedent of the same vintage as Roth. ${ }^{257}$ Pointing out that corporate law had changed since 1907, the court concluded that the contribution was not ultra vires, because it directly related to the business benefit that the company would derive from improved roads. ${ }^{258}$ An even stronger rejection of Roth's public policy approach is evident in Marsili $v$. Pacific Gas of Electric Co. ${ }^{259}$ That case involved corporate contributions in opposition to a referendum that would have placed a limit on the height of all new construction in San Francisco without prior voter approval, a restriction that would have had clearly adverse effects on construction planned by the defendant utility. In rejecting the plaintiffs' ultra vires contention, the California appellate court elaborately restated the implied powers doctrine, and appeared to place the issue of whether a "direct benefit" would result from the

253 H. HENN, supra note 246, § 122, at 203.

254 For the evolution of this "direct benefit" test, see Blumberg, Corporate Responsibility and the Social Crisis, 50 B.U. L. REv. 157, 167 (1970). See also W. GARY, supra note 246, at 58-62.

255 See Note, supra note 247, at 568-76; Comment, Civil Responsibility for Corporate Political Expenditures, 20 U.C.L.A. L. REv. 1327 (1973).

256495 F.2d 844 (2d Cir. 1974).

257 People ex rel. Perkins v. Moss, 187 N.Y. 410, 80 N.E. 383 (1907).

258495 F.2d at 854 .

25951 Cal. App. 3d 313, 124 Cal. Rptr. 313 (1975). 
challenged activity within the protective ambit of the business judgment rule. ${ }^{260}$

Even if the "direct benefit" test governs "improper" payments that do not violate any statute, decisions such as Schwartz and Marsili do not fully resolve the ultra vires issue. Despite broad language in Marsili, both cases dealt with bond referenda on local issues having an immediate effect on the corporation, in a context where the anticipated benefit was specific, tangible, and directly related to the challenged payment. In contrast, most corporate political contributions, both domestic and foreign, have more indirect and ill-defined goals, such as securing an "attentive ear" for possible future resort or warding off potential retaliation. ${ }^{261}$ In such situations, the ultimate benefit is more uncertain, and in many cases the linkage between the payment and that benefit may be beyond the range of proximity that the "direct benefit" test seems to contemplate.

While the prong of the ultra vires doctrine relating to the corporation's authority has been largely eroded, the "agency" prong recently has been sharpened. Here, the issue is whether the corporation has authorized the agent to engage in the challenged conduct. The Restatement of Agency compromises in this area. It states first that "[a]uthority to do illegal or tortious acts, whether or not criminal, is not readily inferred." ${ }^{262}$ Then, it qualifies this rule significantly by providing that "[i]f . . the agent knows that action of this sort has been customary in his principal's business, he has reason to infer his principal's consent thereto, and hence he incurs no liability ...." 263 This qualification closely fits

260 Id. at 324, 124 Cal. Rptr. at 320. Marsili probably is consistent with earlier cases upholding the corporation's authority to make charitable contributions. Those cases similarly accorded a presumption of validity to a management determination that the charitable contribution would benefit the corporation in the long run. See, e.g., A.P. Smith Mfg. Co. v. Barlow, 13 N.J. 145, 154, 98 A.2d 581, 586 (1953); cf. Prunty, Love and the Business Corporation, 46 VA. L. Rev. 467, 474 (1960) (discussing protected areas for managerial discretion in making contributions).

261 Although few modern cases actually have held corporate officials liable for ultra vires acts, some cases have granted injunctions to shareholders to restrain contemplated ultra vires acts by the corporation. See Aiple v. Twin City Barge \&: Towing Co., 274 Minn. 38, 143 N.W.2d 374 (1966); Abrams v. Textile Realty Corp., 97 N.Y.S.2d 492 (Sup. Ct. 1949). Both of these cases enjoined threatened ultra vires acts without a showing that they would have financially injured the corporation in any way. See also W. FLETCHER, supra note 246 , § 5823 .

262 Restatement (Second) of Agency $\$ 34$, Comment g (1958).

263 Id. 
the recurring pattern of long-established foreign payoffs and grease payments. The Restatement, however, does not specifically address the corporate context, and, within that context, the prevalent rule that stockholders lack the power to ratify illegal acts ${ }^{264}$ seems inconsistent with the Restatement position. It follows from the majority rule that the corporate official as agent could not be authorized to engage in an illegal act. On the other hand, these ratification cases are distinguishable from potential improper payments suits in that they deal almost invariably with situations in which those in control of the corporation have allegedly overreached minority shareholders. ${ }^{265}$

Two considerations seem likely to make the agency prong of the ultra vires doctrine particularly attractive to a plaintiff. First, no matter how disposed a court may be to find implied powers, it cannot do so in the face of express corporate disclaimers of authority. Thus, the increasingly common adoption of formal codes of ethics limiting improper payments may have the unintended consequence of subjecting corporate officials to strict liability for losses resulting from violations of these codes. Second, an important line of cases has emerged that amplifies the corporate official's duty of obedience. Several recent decisions hold that, at least where a conflict of

264 See H. HenN, supra note 246, \$ 194, at 380. But see Claman v. Robertson, 164 Ohio St. 61, 128 N.E.2d 429 (1955); Smith v. Brown-Borhek Co., 414 Pa. 325, 200 A.2d 398 (1964). For a decision holding that a longstanding practice that was both ultra vires at common law and in violation of a statute would not support a derivative suit where the stockholders had knowledge and had seemingly acquiesced, see Alderman v. Alderman, 178 S.C. 9, 41, 181 S.E. 897,910 (1935) (discussed at notes 279-85 infra and accompanying text).

265 Almost all of these cases have involved alleged breaches of the duty of loyalty by corporate officials, rather than allegations that corporate officials took excessive or impermissible risks by involving the corporation in some form of misconduct. See $\mathrm{H}$. HENN, supra note $246, \S 194$, at 380 n.11.

Many of the recent cases stating this rule actually deal only with the necessity of demand upon shareholders as a prerequisite to the commencement of a derivative suit, a procedural step that most courts now regard as an onerous burden. See Mayer v. Adams, $37 \mathrm{Del}$. Ch. 298, 141 A.2d 458 (1958), dismissed on other grounds, 40 Del. Ch. 94, 174 A.2d 313 (1961); Continental Sec. Co. v. Belmont, 206 N.Y. 7, 18, 99 N.E. 138, 142 (1912). To this extent, these cases have an ulterior motive that partially explains their unqualified statements that a disinterested majority cannot ratify illegality. See Note, Demand on Directors and Shareholders As a Prerequisite to a Derivative Suit, 73 HARv. L. Rev. 746, 757 (1960). But see Rogers v. American Can Co., 305 F.2d 297 (3d Cir. 1962). Few recent cases have focused on shareholder ratification, because the modern course for a corporation advised by sophisticated counsel is not to "ratify" the transaction, but to make a "business judgment" not to sue the wrongdoer. See Gall v. Exxon, 418 F. Supp. 508 (S.D.N.Y. 1976) (discussed at text accompanying note 462 infra). 
interest exists, the corporate officer as an agent must pass important policy questions on to his principal, the board of directors. In Moses v. Burgin, ${ }^{266}$ the First Circuit employed a novel presumption that amounts to a modern reinterpretation of the ultra vires doctrine. Finding first that the defendant officers of a mutual fund had failed to "communicate effectively" the full circumstances surrounding the possible courses of action open to the board, the court ruled that the defendants had breached their fiduciary duties because such nondisclosure "made impossible the effective functioning of the mechanism protecting the Fund." ${ }^{267}$ There remained the troubling issue of whether the breach had caused injury to the fund. Whether the nondisclosure by the officers to the board caused injury seemingly depended upon whether the board would have taken the undisclosed course of action favored by the plaintiffs, a course that was novel and potentially risky. On the facts of the case, it seemed unlikely. Nevertheless, the court turned to its presumption. Conceding that the undisclosed option represented an "experiment," it still held that for prophylactic reasons it must presume the board would have undertaken the action that nondisclosure denied it the opportunity to consider ${ }^{26 \delta}$ Translated to the broader context of corporate misconduct, the Moses rule might mean that when the officer fails to disclose fully in a conflict situation, the presumption will be that the board would have denied him authority to act as he did.

While Moses $v$. Burgin is unique because of implicit federal fiduciary principles derived from the Investment Company Act of $1940,{ }^{269}$ state cases relying on traditional common-law grounds also have held that the officer's duty of obedience entails a duty of full disclosure to the board. ${ }^{270}$ Therefore, it might be possible to

\footnotetext{
266445 F.2d 369 (Ist Cir.), cert. denied, 404 U.S. 994 (1971).

267 Id. at 384.

268 Id. at $383-85$.

260 For a more detailed discussion of this point, see note 362 infra.

270 See Heit v. Bixby, 276 F. Supp. 217 (E.D. Mo. 1967) (holding that director who became aware of misconduct by other directors and made no protest was "liable as a collaborator in the breaches of trust"); Parish v. Maryland \& Va. Milk Producers Ass'n, 250 Md. 24, 74, 93-94, 105, 242 A.2d 512, 539-40, 550-51, 557 (1968), cert. denied, 404 U.S. 940 (1971); cf. Walker v. Man, 142 Misc. 277, 28I-82, 253 N.Y.S. 458, 465 (Sup. Ct. 1931) (holding that one becoming a director after an illegal transaction, and who becomes aware of but takes no steps to protest or to rectify that transaction, can be held liable for negligence, because acquiescence in wrongful conduct can amount to ratification of it). Not surprisingly, business theorists more than lawyers have focused on the require-
} 
generalize this presumption that a corporate official's action in excess of his authority and undertaken without full disclosure would have been rejected by the board. For the moment, however, it is best to defer our exploration of the theories by which a court could support such a generalized presumption and to focus instead on the attractions of the result the presumption would yield. In this postWatergate era, making participation in a "cover-up" itself a breach of fiduciary duties may be a legal theory whose time has come. More importantly, if we believe that the underlying problems in the area of corporate misconduct center around the problem of information blockages and the imbalance between senior management and the board, it is obvious that this "duty to disclose" approach is a remedy directly addressed to these ills.

\section{c. The "Knowing" Violation}

Assume that the directors of a small construction corporation are aware that corporate officials are making grease payments in order to facilitate progress on various construction projects (i.e., payments to local police not to enforce traffic and parking regulations that, if enforced, would effectively prevent the use of cranes and similar construction equipment in urban areas, payments to building inspectors who otherwise might delay perfunctory approvals interminably, etc.). The directors believe that the amounts so paid are small in proportion to the losses that would result if the payments were refused; nonetheless, while the payments are individually small, they are large enough in the aggregate to present an attractive case to a plaintiff's lawyer willing to handle the matter on a contingent fee basis. What is the legal exposure of these directors?

Assuming that the foregoing example presents a case in which the violation is a knowing one, it is not difficult to find commentators ${ }^{271}$

ment that management be forced to reveal its own involvement in corporate decisions. See Austin, Code of Conduct for Executives, Harv. Bus. Rev., September-October, 1961, at 53 (arguing that disclosure of such involvement is a more meaningful normative injunction than vague concepts such as "business morality").

271 Probably the best summary of the surprisingly undeveloped state of the law regarding "knowing" violations is in Forte, Liabilities of Corporate Officers for Violations of Fiduciary Duties Concerning the Antitrust Laws, 40 IND. L.J. 313, 319-25 (1965). Focusing chiefly on dicta in New York cases, Forte tentatively concludes that these dicta "would lead one to believe that in New York at least the business judgment rule would not relieve [corporate officials] from personal liability for a deliberate violation of the 
and dicta ${ }^{272}$ suggesting that our defendant directors are subject to strict liability, regardless of whether they exercised due care in engaging in the prohibited conduct. ${ }^{273}$ Despite this apparent consensus that it is a per se breach of the duty of due care to place the corporation in violation of the law knowingly, there do not appear to be any modern cases which impose liability on facts even remotely similar to our hypothetical. ${ }^{274}$ Indeed, when examined closely, virtually every modern case imposing liability for intentional violations of law falls into one of the three following categories: (1) violations of statutes expressly and unambiguously governing the internal conduct of corporate affairs (so that the shareholder is within the protected class and a negligence per se theory applies); ${ }^{275}$ (2) violations of law in which self-dealing or a conflict of interests is present (so that it is actually the duty of

antitrust laws even if [they] intended [the] violation to benefit the corporation." Id. at 320. A similarly tentative tone characterizes the conclusions of a student note in the Stanford Law Review:

There are suggestions in the law of corporations that directors are guilty of a breach of trust whenever they cause the corporation to engage in illegal activity. At least this is so when they bring about the illegal activity willfully or knowingly, or for the benefit of other than the corporation.

Note, Stockholders' Suits and the Sherman Act, 5 Stan. L. Rev. 480, 490-91 (1953). Whiting also has noted that "direct precedent is lacking" in this area and the theory of liability must be based on "analogies" and dicta. Whiting, supra note 111, at 48 VA. L. REv. 44-45. For a strong statement of the view that directors should be liable (with some exceptions) even though they intend to benefit the corporation, see Blake, The Shareholders' Role In Antitrust Enforcement, 110 U. PA. L. Rev. 143, 170-78 (1961).

272 For representative dicta, see Cowin v. Jonas, 43 N.Y.S.2d 468, 469 (Sup. Ct. 1943), aff'd mem., 293 N.Y. 838, 48 N.Y.S.2d 460 (1944). Cowin held, in the context of an illegal dividend, that good faith could not be a defense to a statutory violation. Such cases involving illegal dividends or other statutes designed to safeguard creditors clearly deal with members of the "protected class" of the statute, and so are distinguishable. See also Abrams v. Textile Realty Corp., 97 N.Y.S.2d 492, 495 (Sup. Ct. 1949) (discussed at note 301 infra); cases cited at note 236 supra.

273 Recall that "strict liability" here refers to the imposition of liability without the possibility of affirmative defenses. See p. 1162 supra. The only defense under the instant theory, given that the violation was a "knowing" one, might be the claim that it produced no net loss, since it averted greater economic injury to the corporation.

274 The cases surveyed in making this statement include those cited in W. FLETCHER, supra note 246, $\$$ 1021-1024; Blake, supra note 271; and Forte, supra note 271 . The only exception appears to be Roth v. Robertson, 64 Misc. 343, 118 N.Y.S. 351 (Sup. Ct. 1909).

275 As Professor Blake has noted, these cases typically involve (a) laws regulating the lending capacities of financial institutions and (b) illegal dividends. Blake, supra note 271, at 160-6J, nn. 77, 78, 80, \& 81. As discussed earlier, Miller v. AT\&:T, 507 F.2d 759 (3d Cir. 1974), also falls into this category. See also W. FLETCHER, supra note 246, § 1024; note 278 infra. 
loyalty that the court is enforcing); ${ }^{276}$ or (3) violations of law by subordinate officials acting beyond the scope of their delegated authority (so that the ultra vires doctrine underlies the result). ${ }^{277}$

The absence of a modern case holding defendants strictly liable for intentional illegality supplies at best a negative inference. This, standing alone, provides less than complete assurance for our hypothetical defendant directors when measured against the confident statements in dicta. Yet, when one examines the cases most often cited by commentators for the proposition that directors are liable when they "knowingly" exceed their authority "without regard to the exercise of reasonable care," ${ }^{278}$ it becomes evident that these decisions-in particular Alderman v. Alderman ${ }^{279}$ and Simon v. Socony-Vacuum Oil Co. ${ }^{280}$-suggest the existence of other defenses besides that of good faith.

Several aspects of Alderman, a 1935 South Carolina case, show the flexibility with which a court sympathetic to defendant directors can manipulate legal doctrines to achieve a desired result. In Alderman, the directors had caused the corporation to invest in several major banks, despite a statute that prohibited corporate investments in banks and a common-law rule that made such investments ultra vires. During the Depression, the value of these seemingly prudent investments declined drastically, and several stockholders sued to force the directors to indemnify the corporation

276 Sellers v. Head, 261 Ala. 212, 73 So. 2d 747 (1954) (corporate president intentionally filed false tax returns to hide his own fraudulent conversions from the corporation); Hill v. Murphy, 212 Mass. I, 98 N.E. 781 (1912) (directors intentionally circulated a libel for their own personal ends); DiTomasso v. Loverro, 250 App. Div. 206, 293 N.Y.S. 912, aff'd mem., 276 N.Y. 551, 12 N.E.2d 570 (1937) (antitrust violation alleged to have been engaged in to benefit other corporation in which defendant directors were interested); Clayton v. Farish, 191 Misc. 136, 73 N.Y.S.2d 727 (Sup. Ct. 1947) (entry into cartel agreement in violation of the antitrust laws recognized as a potential breach of the directors' duty of loyalty where entry motivation was to benefit another corporation).

277 Wilshire Oil Co. v. Riffe, 409 F.2d 1277, 1284 (10th Cir. 1969) (citing corporation's "traditional common law right to recover for injuries occasioned by errant employees"). See also cases cited by Blake, supra note 271 , at 161 n.82.

278 See W. FLETCHer, supra note 246, $\$ 1023$ (discussing cases cited at notes 279-80 infra). This treatise adds, however, that where neither a statute nor the charter imposes express liability on corporate officials for violation of a statute, courts would not impose liability "merely because the act is a violation of the charter or a statute." Id. $\S 1024$. Fletcher suggests that the test might be whether the statute imposes "restriction on the power of the corporation or the powers or duties of the directors themselves." Id.

279178 S.C. 9,181 S.E. 897 (1935).

280179 Misc. 202, 38 N.Y.S.2d 270 (Sup. Ct. 1942), aff'd mem., 267 App. Div. 890, 47 N.Y.S.2d 589 (1944). 
for its losses on these illegal investments. The court absolved the directors, based in part on an expansive view of the good faith defense. The fact that they "may well have believed" 281 the investments to be permissible satisfied the Alderman court, although courts usually have required reliance upon counsel or statutory ambiguity for the good faith defense. ${ }^{282}$ But the decision emphasized even more that the illegal investments had been a "longstanding" practice of the corporation, in which stockholders had acquiesced. ${ }^{283}$ Finally, the court declared that a derivative suit, being a suit in equity, was "a matter peculiarly of equitable cognizance which cannot be determined by legal considerations alone." ${ }^{284}$ The scope of the applicable equitable defenses is far from clear, but the opinion contains at least a suggestion that when the directors did not explicitly recognize their conduct to be illegal, an intent to benefit the corporation would receive considerable weight. ${ }^{285}$

The second case, Simon v. Socony-Vacuum Oil Co., was a 1942 New York decision that absolved directors from tort liability for antitrust violations when the directors, acting with reasonable care, did not believe their acts were illegal. More importantly for present purposes, the court framed a formula for strict liability that distinguished between classes of illegal acts:

Whether directors are personally liable for committing acts prohibited by statute depends upon the nature of the prohibited act;

281178 S.C. at 40,181 S.E. at 910.

282 See cases cited at note 236 supra; Blake, supra note 271, at 160-61. For a discussion of the effect of reliance upon counsel, see text accompanying note 361-66 infra.

283178 S.C. at $4 \mathrm{I}, 18 \mathrm{I}$ S.E. at 910 . The court quoted with approval the following statement of the special referee:

It is" hard, therefore, for me to see how the corporation in view of its action for more than thirty years could now undertake to hold its directors personally accountable for continuing these long-standing practices, and how the individual stockholders can object, when they have heretofore acquiesced in and have actively participated in [the illegal investments].

Id. Whether the approach of the Alderman court in this regard would be extended beyond the context of the close corporation is open to question. However, some public corporations have disclosed an intention to continue making small grease payments. See notes 67-68 supra. There, Alderman would have considerable relevance.

284178 S.C. at 42 , 181 S.E. at 910 (adopting lower court opinion). The court emphasized that the directors acted with "honesty of purpose" in seeking to benefit the corporation and that they exercised considerable diligence. $I d$., 181 S.E. at 911.

285 Id. 
whether the statute is plain and unambiguous, and whether it contains a limitation or restriction on the powers of the corporation or the powers or duties of the directors themselves. ${ }^{286}$

Because the decision emphasized that prior New York cases holding directors strictly liable involved violations of statutes specifically focused at directors, such as statutes limiting their power to declare dividends or to make loans or investments, Simon seems to suggest that some penal statutes are incorporated by reference into the corporation's charter, becoming substantive limitations on the directors' power, while others are not. ${ }^{287}$

Analytically, the Simon test has much in common with both the ultra vires and the negligence per se approaches. Under the ultra vires theory, a penal statute that does impose a "limitation or restriction" (to use the Simon phrase) seems to have the same effect as a charter restriction curtailing the directors' discretion. Under a negligence per se approach, any statute found to contain such a "limitation or restriction" also likely would be found to include shareholders within its "protected class." 288 Thus, there is a basic congruence among the triggering concepts of these three doctrines, and a likelihood that they would produce identical results in a given fact situation.

The most important question that Simon raises (but does not answer) is where the watershed would lie between statutes that do impose restrictions on the corporation's power and those that do not. Read literally, very few statutes would seem to impose such

286179 Misc. at 204, 38 N.X.S.2d at 274 (emphasis added).

287 The distinction among statutes in Simon finds support in other cases. Judge Lumbard's concurring opinion in Spirt v. Bechtel, 232 F.2d 241 (2d Cir. 1956) (discussed at note 231 supra), concluded that the statute there at issue was in no way "a measure of the obligation" of the defendant directors, although it did seemingly protect shareholders. Id. at 248. In Schwartz v. Romnes, 495 F.2d 844 (2d Cir. 1974), the Second Circuit, after determining that the state statute against corporate political contributions had not been violated, implied in dicta that even if there had been a violation, the court would still have had to determine whether "a private derivative right of action may be implied in favor of plaintiff." Id. at 854 .

288 It can be argued that some statutes clearly intended to impose restrictions on corporate power, such as the typical statutory restrictions on the lending, borrowing, and investment powers of financial institutions, are not intended to protect shareholders; but only creditors, depositors, and the Federal Reserve System. See Holman v. Cross, 75 F.2d 909 (6th Cir. 1935). I think the better view, however, would be to view such statutes as intended to protect shareholders from excessive management risks. An analysis of these conflicting interpretations appears in Michelsen v. Penney, 135 F.2d 409 (2d Cir. 1943), particularly the opinion of Judge Augustus Hand, id. at 435-37. 
limitations under the standard that Simon seems to employ. ${ }^{289}$ Even if we broaden that category to include statutes aimed principally at corporations, it would still require conceptual acrobatics in our earlier construction company hypothetical to treat municipal regulations or laws proscribing petty graft as similarly incorporated into the corporation's charter.

If Simon suggests that courts, at least in the past, have approached the problem of knowing illegality by the rather formalistic route of asking what powers were delegated to corporate officials, the conceptual limitations of this approach become clearest in the multi-jurisdictional context. For example, do the officers of a corporation incorporated in a state that prohibits neither commercial bribery nor political contributions exceed their delegated powers by engaging in these acts in another jurisdiction, which does prohibit such conduct? If the jurisdiction of incorporation both lacks a similar prohibition and follows the Simon approach of considering only some statutes as imposing restrictions on corporate power, then it is possible for a court in that jurisdiction, or in a jurisdiction following the traditional conflicts rule, ${ }^{290}$ to treat the statutory violation, even if "knowing," as only "evidence of negligence" or less.

One of the few cases that has even skirted this issue of statutory violations in a multi-jurisdictional context is Polon $v$. Huffines, ${ }^{291}$ which adopted an "evidence of negligence" approach. In Polon, plaintiffs were stockholders of an Ohio corporation that had been convicted of violating an Illinois regulatory statute. They sought to hold the former majority shareholder, who had dominated the corporation, liable for the fines imposed. The Seventh Circuit

289 The cases relied upon by Simon seem basically to have involved statutes that include shareholders within their protected class. See I79 Misc. at 204-05, 38 N.Y.S.2d at 274. If this were the watershed between statutes that impose liability and those that do not, relatively few criminal statutes would be included.

290 Under section 309 of the Restatement (Second) of Conflict of Laws, the law of the state of incorporation is to apply with respect to "internal affairs" of the corporation, including issues involving the liability of corporate officials to the corporation. RESTATEMENT (SFCOND) OF CONFLICT OF LAws $\$ 309$ (I97I). The one recognized limitation on this rule is that where the sole contact between the corporation and its state of incorporation is that it is incorporated there, the laws of another jurisdiction having a closer relationship to the corporation may be applied. See Mansfield Hardwood Lumber Co. v. Johnson, 268 F.2d 317, 32I (5th Cir.), cert. denied, 361 U.S. 885 (1959). For citations to cases following the Restatement, see Forte, supra note 271 , at 318 n.33.

291446 F.2d 384 (7th Cir. 197I). 
rejected this claim, stating that it could find "no authority which imposes strict liability for errors of business judgment in the absence of a conflict of interest or applicable statute of the state of incorporation." ${ }^{292}$ The court concluded that therefore the appropriate standard was to be derived "by reference to traditional notions of negligence." ${ }^{293}$ The court held the claim inadequate under this standard, stating: "While the fact that criminal liability was imposed is evidence of the erroneous nature of defendant's judgment, neither the plaintiff nor the corporation has argued or introduced evidence under a negligence theory." ${ }^{294}$ But what additional elements did the plaintiff's case here need to create at least a prima facie showing of negligence, which the defendant might be able to rebut by raising an affirmative defense? Apparently, the Polon court found the criminal conviction insufficient to constitute such a showing. Thus, at a minimum, it seems to place the burden of showing negligence on the plaintiff even after a statutory violation has been demonstrated. But what constitutes negligence in this context? Must the plaintiff also prove that violation was knowing, reckless, or not "excusable"?

Where there has not been any prior conviction, unlike Polon or Simon, the problem for a court in a jurisdiction different from that in which the statutory violation occurred is even more complex. In general, courts have been highly reluctant to make determinations involving the criminal laws of another jurisdiction. For example, suppose a plaintiff wished to bring suit in a state court alleging improper payments in violation of the RobinsonPatman Act. Although the foreign statute here is federal, and governs under the Supremacy Clause, a series of New York cases have dismissed even these attacks on either of two grounds. First, they have held that a lack of jurisdiction over the statute prevented them from adjudicating the dispute, unless the conduct also amounted to a breach of the duty of loyalty. ${ }^{295}$ This much-criticized approach essentially says that although courts can examine conduct alleged to have violated foreign law to determine if there has been

$292 I d$. at 386 (emphasis added).

293 Id.

294 Id.

295 See, e.g., Clayton v. Farish, 191 Misc. 136, 73 N.YS.2d 727 (Sup. Ct. 1947); cf. Gomberg v. Midvale Co., 157 F. Supp. 132 (E.D. Pa. 1955) (dismissed complaint because plaintiffs failed to prove personal advantage to directors, as required by Delaware law). 
an underlying breach of the duty of loyalty, they cannot find a breach of the duty of due care based simply on the violation of the foreign statute. ${ }^{296}$ Second, several cases have concluded that because the most reasonable inference to be drawn from illegal behavior is that it was undertaken for corporate profit, plaintiffs should bear the burden of proving that the corporation suffered a net loss-in short, that the crime did not pay. ${ }^{297}$

We will return to the New York "net loss" rule in our survey of affirmative defenses. ${ }^{298}$ Obviously, there are powerful policy reasons operating against the adoption of a test that focuses on such pragmatic questions as whether the costs of compliance outweigh the costs of violation or whether it is a reasonable business risk to violate a statute. Such an approach would introduce exactly the opposite of the considerations that we would want from a public policy perspective to influence the judicial balancing process (e.g., how likely am 1 to get caught?, how much will it cost me?). But how does a court avoid such a descent into cynicism other than by use of a strict liability theory? One way is the net loss rule's approach: assign such an onerous burden of proof to the plaintiff that the case cannot come to trial. ${ }^{299}$ An alternative might be the reverse approach: a conclusive presumption that obedience to the law is beneficial, and thus all knowing violations become per se reckless ones.

In support of such a presumption, there is evidence from the improper payments experience that such payments (and by analogy other forms of corporate misconduct) are ultimately inconsistent with profit maximization, even if profitable in the short run. Still, while an honorable sentiment, there is a glib profundity to this argument that illegal conduct is as a matter of law always counterproductive in the long run. "In the long run," said Keynes, "we are all dead." To the directors of a corporation teetering on the brink of insolvency, or facing a confiscatory nationalization, there is a telling force to Keynes's observation that cannot be countered by a focus on the long term. Circumstances objectively

296 See Blake, supra note 271, at 166-68; Forte, supra note 271, at 317-18, 319 n.35; Comment, supra note 238, at 904 . Some New York cases have reached an opposite result, but have not explained their reasoning. See, e.g., Knopfler v. Bohen, 15 App. Div. 2d 922, 225 N.Y.S.2d 609 (1962) (allowing claim under federal antitrust laws).

297 See cases cited at note 417 infra.

298 See text accompanying notes 417-25 infra.

299 See text accompanying notes $417-22$ infra. 
can arise in which the gain or loss of a profitable contract or the prevention of hostile governmental action could mean the difference between solvency and insolvency. Undeniably too, the risk of enforcement, the severity of the penalty, and the potential profitability of the prohibited conduct are all relevant considerations that the rational man would weigh when deciding whether or not to breach a statute-or if not, then theories about general deterrence that have shaped the criminal law at least since the day of Bentham and Beccaria are profoundly misguided. A partial answer to these arguments might be that there is a difference between predicting what factors the rational man will consider in evaluating a risk and determining the standard for the prudent man serving as a director. Traditionally, the determination of whether conduct was negligent under a "reasonable man" standard always has involved some element of moral evaluation. ${ }^{300}$ Thus, it is not surprising to find that other New York cases in a related context have adopted what amounts to a conclusive presumption that obedience to law always benefits both the corporation and its shareholders. ${ }^{301}$

The coexistence in the same jurisdiction of this line of cases and the "net loss" rule demonstrates the difficulties inherent in the problem. Although corporate misconduct clearly is not always contrary to the corporation's own interests, one could argue that a presumption of harm to the corporation may be at least a useful legal fiction to increase the level of deterrence. However, the Supreme Court recently rejected exactly such a use of deterrence as a justification for liability when a plaintiff stockholder had suffered no economic loss. ${ }^{302}$ Still, because the Supreme Court has

300 See F. Harper \& F. JAMes, supra note 226, $\$ 16.4$, at 906 . Balancing this observation, however, is the dictum of Professor Seavey, one of the original draftsmen of the Restatement, that "[e]xcessive altruism is as much a departure from the standard morality as excessive selfishness." Seavey, Negligence-Subjective or Objective?, 41 HARv. L. Rev. Il (1927).

301 In Abrams v. Textile Realty Corp., 97 N.Y.S.2d 492 (Sup. Ct. 1949), the courtappointed referec observed: "The law cannot refuse to recognize as beneficial full observance of the law. The law cannot hold that corporate interests are better served by action outside rather than within the law." Id. at 496. Although this statement has been much quoted, the specific issue in dispute was not illegality nor even any issue involving the liability of individual corporate officials. Instead, the case involved only whether the plaintiff was entitled to have his legal expenses for securing an injunction against an ultra vires act paid by the defendant corporation.

302 In Bangor Punta Operations v. Bangor \& A.R.R., 417 U.S. 703, 717 (1974), the Court rejected the First Circuit's argument that liability had to be imposed against a 
expressly disclaimed the power to federalize questions of state corporation law, ${ }^{303}$ its skepticism towards such a presumption is not an insurmountable barrier.

More important is the possibility that such a presumption actually might be counterproductive in its effect on corporate misconduct. From our organization theory perspective, the key problem with such a conclusive presumption is that it eliminates any positive incentive for subordinate corporate officials to disclose questionable practices to their superiors. Effectively ensuring that the board has no discretion to enter a gray area would intensify the problem of information blockages. Once strict liability becomes the governing standard, and the board may not legitimize questionable payments, there is no reason for lower-echelon officials to inform their superiors when they make or contemplate making such payments. By doing so, they would only implicate their superiors as well without gaining any corresponding advantage. Indeed, prior disclosure might well jeopardize the board's ability to make a business judgment determination not to sue them if a derivative suit ever were commenced. ${ }^{304}$ In contrast, if the board-and only the board-could legitimize certain questionable practices (particularly in a "duress" situation such as our earlier Gulf Oil paradigm), the resultant safe harbor could create a positive incentive that induces a flow of adverse information to higher levels within the corporation. For maximum effect, this safe harbor could be coupled with appropriate negative incentives for those who fail to disclose (possibly by expanding the presumption of Moses $v$.

former majority stockholder of a railroad who allegedly had looted it, in order to "provide a needed deterrent to mismanagement of railroads." The Court stated:

Our difficulty with this argument is that it proves too much. If deterrence were the only objective, then in logic any plaintiff willing to file a complaint would suffice. No injury or violation of a legal duty to the particular plaintiff would have to be alleged. The only prerequisite would be that the plaintiff agree to accept the recovery, lest the supposed wrongdoer be allowed to escape a reckoning. Suffice it to say that we have been referred to no authority which would support so novel a result, and we decline to adopt it.

To the extent that this case reflects the Court's current attitude toward theories of corporate misconduct, it suggests that the Court will not dispense with formal requirements nor ignore traditional legal distinctions.

303 Santa Fe Indus., Inc. v. Green, 430 U.S. 462, $479-80$ (1977); Cort v. Ash, 422 U.S. 66, 84 (1975).

304 For a discussion of the problems such prior board involvement might create in the context of the board's power to decide not to sue, see text accompanying notes 473-79 infra. 
Burgin, discussed earlier ${ }^{305}$ ). These alternative approaches present again the conflict between a moralistic approach of imposing sterner penalties and a pragmatic approach of improving the ability of the corporation's own self-regulatory devices to supervise questionable activities. If our ultimate end is prevention and if the most effective means to that end involves increasing the flow of information within the corporation, then the wisest strategy may not be the most punitive, but rather the one that best combines positive and negative incentives.

On the operational level of legal doctrine, there is a possible intermediate position between the presumption that obedience to the law is always beneficial to the corporation and the net loss rule followed by some New York courts that might allow us to implement such a policy of mixing incentives. Given the likelihood that the defense of justification or duress will legitimately arise only in a minority of cases, a wiser course might be to establish a rebuttable presumption that intentional violations of law violate the duty of due care. Then, having permitted the plaintiff to establish a prima facie case by virtue of the presumption, the defendants could assert their justifications as an affirmative defense. One recent case has taken this approach, holding that it is defendants' responsibility to show that the violation should be excused. ${ }^{306}$ For the moment, let us postpone the issue of what defenses might meet the defendants' burden and simply note that such a compromise would facilitate a strategy consistent with our earlier diagnosis without by any means granting immunity to those guilty of active misconduct. ${ }^{307}$

305 See text accompanying notes 266-68 supra.

306 See Parish v. Maryland \& Va. Milk Producers Ass'n, 250 Md. 24, 80-81, 242 A.2d 512, 543-44 (1968) (holding that a violation of the antitrust laws would not, "per se, result in a finding of gross negligence or culpable mismanagement," but that the allegations did establish such conduct prima facie so that the defendants would be required to rebut such a presumption at trial).

307 Such individuals would remain exposed to criminal liability if the acts were illegal in the jurisdiction in which committed, regardless of the law of the state of incorporation or the governing conflicts rule. See, e.g., N.Y. PenAL LAw $\$ 20.25$ (McKinney 1975) (holding responsible officials criminally liable for criminal corporate conduct). Some recent case law suggests that the responsible officials could also be held liable by injured third parties if the conduct amounts to an intentional tort. See Tillman v. Wheaton-Haven Recrcational Ass'n, 517 F.2d 1141 (4th Cir. 1975) (holding directors of a nonprofit corporation personally liable for discriminatory corporate action in which they participated despite reliance on the advice of counsel). 


\section{Negligence Theories}

Consideration of "knowing" violations must be kept in perspective. Even a combination of knowing and "reckless" violations probably represents only a minority of the total number of corporate transgressions of statutory or regulatory standards. In the typical situation, the defendant directors are alleged to have acted negligently by failing to discover illegal actions that in the exercise of reasonable care they should have uncovered.

Although the case law supports the abstract proposition that a director has a duty to exercise reasonable supervision over the corporation's officers, ${ }^{308}$ any attempt by a plaintiff to prove a breach of this duty faces the formidable obstacle of Graham $v$. AllisChalmers Manufacturing $\mathrm{Co}^{309}$ That case absolved directors from liability for antitrust price-fixing violations by subordinate management, because the directors had neither actual knowledge nor grounds for suspecting the conspiracy. More importantly, Graham stated two subtly different propositions: (1) "that directors are entitled to rely on the honesty and integrity of their subordinates until something occurs to put them on suspicion that something is wrong," ${ }^{310}$ and (2) that they are under "no duty ... to install and operate a corporate system of espionage to ferret out wrongdoing." ${ }^{311}$ While both of these propositions stem from the earliest Supreme Court cases on directors' liability, ${ }^{312}$ and while the first proposition may melt at its margins into the second, it nevertheless

308 Bates v. Dresser, 25l US. 524 (1920); Teren v. Howard, 322 F.2d 949 (9th Cir. 1963); Parish v. Maryland \& Va. Milk Producers Ass'n, 250 Md. 24, 242 A.2d 512 (1968); Neese v. Brown, 218 Tenn. 686, 405 S.W.2d 577 (1964); Annot., 25 A.L.R.3d 941 (1969).

30941 Del. Ch. 78, 188 A.2d 125 (1963).

310 Id. at 85,188 A.2d at 130 .

311 Id. The court also noted that: "By reason of the extent and complexity of the company's operations, it is not practicable for the Board to consider in detail specific problems of the various divisions." Id. at 82,188 A.2d at 128 . The Graham court thus recognized the "control loss" problem and the infeasibility of monitoring from the board's "crow's nest" vantage point. In the courts of Delaware, however, to recognize a problem is not necessarily to suggest that it be solved.

312 Graham relies chiefly on the Supreme Court's early 5.4 decision in Briggs v. Spaulding, 141 U.S. 132 (1891), which exonerated directors alleged to have inadequately supervised their subordinates. For more recent decisions employing stricter standards, see note 308 supra and note 313 infra. Even some early cases seem to have required corporate officials to take precautions beyond looking for signs of untrustworthiness in their subordinates. See Chadwick v. Holm, 31 Idaho 252, 170 P. 87 (1918) (holding corporate officer liable for negligent failure to bond against employee embezzlements). 
is worth asking if we can question and curtail the second while acknowledging the basic legitimacy of the first.

The first proposition, reliance on subordinates, has an inherent equity that makes its rejection by courts seem unlikely. Indeed, even cases imposing liability generally have followed Graham's approach, seeking first a telltale "clue" that should have put the directors on notice. The deficiency in this approach, however, lies at the point where it meets Graham's second proposition, that directors have no obligation to institutionalize any mechanism for monitoring internal compliance. What happens after the clue is found, an ad hoc investigation made, and no smoking gun uncovered? A court then has essentially three options. First, it could follow Graham and absolve the directors because they were entitled to conclude their investigation upon finding no corroborating evidence. Second, it could find another clue that should have caused the directors to search further. Or third, it could abandon reliance on clues and instead require directors to install some permanent monitoring system once the corporation has grown to a size that precludes effective personal supervision by the board.

This third approach directly contradicts Graham's second rule, but the alternatives are bleak. Absolving the directors after a cursory investigation would institutionalize the problem of the shut-eyed sentry by placing corporate officials in risk of liability only if they have notice of the impropriety. Although there have been recent decisions in which courts have searched for clues with the $20 / 20$ vision of hindsight, ${ }^{313}$ the primary limitation of this approach is obvious: unless one is prepared to hold directors liable for clues that might have escaped Hercule Poirot, one cannot expect directors in the modern decentralized corporation to discover many clues from their remote position in the corporate crow's nest. Therefore, if we accept that the locus of corporate misconduct is generally at levels far below top management, and that the board's effective "span of control" necessarily is limited, then the only pragmatic approach is to require systematic internal monitoring.

313 From the standpoint of the corporate director, probably the most frightening of these decisions is DePinto v. Provident Security Life Ins. Co., 374 F.2d 37, $43-44$ (9th Cir. 1967), which imposed damages of $\$ 314,794$ for failure of a director to investigate and to discover that a proposed shift in control would be "inimical to the best interests" of his corporation. 
But can we realistically expect courts to reverse the consensus of authority that directors have no duty to install any such "espionage system" (in Graham's pejorative phrase)? Some perspective on this problem is gained when one recalls prior moments in the law of torts when courts have recognized that a change in circumstances necessitated new standards of care. The classic expression of this judicial power to upgrade a standard of reasonable care is Learned Hand's opinion in The T.J. Hooper. ${ }^{314}$ That famous case involved the question of whether the operator of several ocean-going barges lost in an Atlantic gale was liable for failure to install on board a radio receiving set, which would have warned him in time of the approaching storm. The defense was that because the industry had not generally adopted the use of such receiving sets, their non-use did not breach the standard of care expected of a reasonably prudent man. Learned Hand responded:

Is it then a final answer that the business has not generally adopted receiving sets? There are, no doubt, cases when courts seem to make the general practice of the calling the standard of proper diligence .... Indeed, in most cases reasonable prudence is in fact common prudence; but strictly it is never its measure; a whole calling may have unduly lagged in the adoption of new and available devices. It never may set its own tests, however persuasive be its usages. Courts must in the end say what is required; there are precautions so imperative that even their universal disregard will not excuse their omission. ${ }^{315}$

Is the position of corporate director such a "calling" that has "unduly lagged in the adoption of new and available devices"? Graham ignored this question, simply assuming that a system of internal monitoring was unnecessary because it previously had been unnecessary. ${ }^{316}$ But, the period between Graham and the earlier decisions on which it relied saw the transition from the traditional unitary corporation to the inodern multidivisional corporation. With this metamorphosis came also the problems described earlier of communication distortion, authority leakage, and subgoal pursuit. Similarly, the nature of corporate misconduct has changed significantly. We are no longer concerned solely with the

31460 F.2d 737 (2d Cir. 1932).

315 Id. at 740 .

316 See note 312 supra. 
absconding cashier, ${ }^{317}$ but rather with the conscientious vice president who fixes prices. ${ }^{318}$ With this rise of "regulatory" offenses, the idea of "telltale clues" becomes an ineffective legal antique. Its original premise was that signs of "untrustworthiness" would alert the diligent director before the impending crime. That premise does not apply to the problem of managerial overzealousness.

Does all this mean that, at the risk of otherwise incurring personal liability, directors might be required to establish a permanent office within the corporation primarily responsible for internal surveillance-in effect, a corporate Inspector General? ${ }^{319}$ Tempting as such a conclusion might be, such a quantum leap in legal standards probably exceeds the current reach of any possible tort law approach. Hooper, after all, required only that the defendants buy a radio already on the market, not that they hire Marconi to invent one. But two less drastic remedies, which already have received some degree of acceptance, should constitute "available devices" within the meaning of Hooper. The first remedy is equipping the outside members of the board with their own staff. ${ }^{320}$ This idea remains controversial, but some tentative steps in this direction are discernible. ${ }^{21}$ The second remedy, the audit committee, is less

317 See Bates v. Dresser, 251 U.S. 524 (1920)

318 See Graham v. Allis-Chalmers Mfg. Corp., 41 Del. Ch. 78, 188 A.2d 125 (1963).

319 Stanley Sporkin, Director of the SEC's Division of Enforcement, has recently suggested such a reform. He has called for the creation of "business practices officers" to "ferret out improper business practices within the corporation and bring them to the attention of the board of directors." Berry, SEC's Sporkin Hits Business Crime, Wash. Post, June 17, 1977, at D8, col. 1. Such a system seems vulnerable to the same criticisms as an expanded staff system. In particular, it seems unlikely that talented young executives would serve willingly in a position offering so little promise of future advancement.

320 See note 193 supra.

321 A recent survey by Korn-Ferry International, a management recruiting firm, found that of 370 major corporations surveyed, only $6.5 \%$ reported that they provided directors with full-time or part-time staff assistance. Fowler, Management: Defining Role of a Corporate Director, N.Y. Times, Mar. 25, 1977, at D3, col. 1. Low as the figure is, it appears to signify an increase. For a description of the very limited information directors typically receive today, see M. EIsfNBfRs, supra note 12 , at 143-44.

One idea related to a staff system that has gained recent adherents is the "officer of the board" system. As first developed by Texas Instruments, this approach is to take a senior officer of the company, such as an executive vice president, and make him a full-time professional director, free from all operating responsibilities. The Mead Corporation and Connecticut General Insurance Company have adopted variants of this approach. Fowler, supra. Exxon also has followed a similar practice. C. Brown, supra note 9, at 33-34. While it may be premature to appraise this experiment, it seems likely that (a) such an insider may find it difficult to be as skeptical as an outside director who is not substantially 
open to question. Indeed, it already has become prevailing practice. ${ }^{322}$ Under an audit committee system, the corporation's outside auditors report directly to a committee of the board's outside directors. The intended result is to out-flank the problem of information blockages by giving the board access to information, unfiltered by management, on problem areas in the corporation's financial performance. Within the area of accountants' expertise, such a structure performs some of the same functions as a mini-board system: it serves as an early warning system within the corporate structure to warn the board of impending problems, and it alerts the board to the degree of distortion in the information reaching it by regular channels. Enthusiasts of the audit committee approach have suggested that its role be expanded beyond financial matters, enabling a systematic "social audit" of the corporation's activities. ${ }^{323}$

Accountants, both academics and practitioners, however, are more skeptical. They have warned that auditing techniques are rarely adequate to detect outright fraud and have cautioned that accountants are not competent to audit nonfinancial aspects of the corporation's behavior. ${ }^{324}$ Moreover, from the perspective of this

dependent on the corporation for his livelihood; (b) the temptation may arise to use such a position as a sinecure for the "burnt out" case or the losing candidate in the competition for some other corporate post; and (c) the post may be difficult to fill because the best qualified candidates may not wish to detach themselves from the corporate hierarchy so completely (thereby forfeiting the opportunity to become chief executive officer). Fowler reported (perhaps symptomatically) that the post on the Texas Instrument board bad gone vacant. See Fowler, supra.

$32280 \%$ of tbe companies responding to a 1974 survey of New York Stock Exchange members reported having audit committees; another $13 \%$ reported plans to establish one. M. EISENBERG, supra note 12, at 207-08. Under a recently adopted New York Stock Exchange rule, which becomes effective on June 30, 1978, each corporation listed on that exchange will be required to establish a qualifying audit committee. SEC Exchange Act Release No. 34-13245, 42 Fed. Reg. 8,737 (1977). For the background of this rule and the SEC's approval of it, see SEC Exchange Act Release No. 34-13346, 42 Fed. Reg. 14,793 (1977), and note 386 infra.

323 Branson, Progress In the Art of Social Accounting and Other Arguments for Disclosure on Corporate Social Responsibility, 29 VAND. L. REv. 539 (1976).

324 This view was articulated most forcefully in Foreign Payments Disclosure: Hearings on H.R. 15481 Before the Subcomm. on Consumer Protection and Finance of the House Comm. on Interstate and Foreign Commerce, H.R. Rep. No. 94-115, 94th Cong., 2d Sess. (1976) (Testimony of Thomas Holton, Chairman, Comm. on SEC Regulations, American Inst. of Certified Public Accountants). At these hearings, the AICPA took the following position: "We believe it is critically important to . . . recognize that illegal or improper corporate activities can and will oceur regardless of the strength of internal accounting 
article, reforms such as the audit committee or the expanded board staff seem likely for a variety of reasons to yield only marginal improvements in the board's effectiveness. A substantial organizational distance would still remain between the board and the locus of most corporate misconduct; positive incentives for a fuller flow of sensitive information to the board still would be lacking. Unlike improper payments, most forms of corporate misconduct do not involve the falsification of financial records or other evasions of accounting controls. Finally, by their nature, accounting safeguards offer only retrospective, rather than prospective, controls. ${ }^{325}$

Nevertheless, the example of the audit committee illustrates the capability of a negligence theory approach for producing desired change. The effectiveness of negligence theory lies in its ability to force the pervasive adoption of reforms once they have become "available." For example, under prodding from the SEC, the New York Stock Exchange has recently amended its listing requirements to limit trading to securities of corporations having such an audit committee. ${ }^{326}$ As the audit committee thereby becomes widely accepted, there inevitably will be corporate stragglers among corporations not listed on the New York Stock Exchange. The directors of such a straggler should face a high exposure to liability based on negligence if their failure to adopt a reform of proven feasibility harms the corporation. ${ }^{327}$ Moreover, this process could constantly

controls, because no system has yet been devised that can withstand collusive behavior or circumvention by corporate officials." Id. at 158 (emphasis added). The AICPA testimony added that "a careful analysis" of those cases studied in the SEC Payment Report would show that "[a]ll of those cases involved companies that had systems of internal accounting control ... [that were] very good systems." $I d$. The problem, it added, was that these systems had been deliberately circumvented by corporate insiders. In our terminology, information was being "blocked." For similar comments from a respected academic accountant (N.Y.U. Professor Lee Seidler), see Why Everybody's Jumping on Accountants These Days, Forbes, Mar. 15, 1977, at 37, 43.

325 Even ideal accounting controls tell a board only what has happened, not what is about to happen. For the board as the corporate superego to have an advance role before decisions become faits accomplis, other forms of monitoring, such as the mini-board, are necessary.

326 See note 322 supra.

327 The AICPA reluctantly has accepted the proposition that an auditor has a responsibility to respond to indications that "irregularities," which are defined to include "intentional distortions" such as slush funds and management misrepresentations, exist in the financial statement. Auditing Standards Executive Comm., AICPA, Statement on Auditing Standards No. 16: THE INDEPENDENT Auditor's RESPONSIBILITY FOR THE DETECTION of Errors or Irregularities (Jan. I977) ; see AudtTing Standards Executive Comm., AICPA, 
repeat itself: if a more comprehensive structural reform, such as the mini-board, ever achieves a reasonable degree of acceptance and demonstrated effectiveness, the negligence approach could similarly induce its general acceptance.

One major caveat, however, to the conclusion that courts could use a negligence approach to spur the installation of adequate internal corporate monitoring systems is the approaching codification of the Graham rules. As revised in 1974, section 35 of the Model Business Corporation Act grants directors a specific defense of reliance upon advice and information given them by certain categories of persons. ${ }^{328}$ The novel feature of this provision is that it permits reliance not only upon experts, such as attorneys and accountants, or upon highly technical data, such as financial statements, but also upon "information, opinions, reports or statements ... prepared or presented by ... officers or employees of the corporation ...." ${ }^{329}$ This sweeping extension of the reliance

Statement on Auditing Standards No. 17: Illegal Acts by Clients (Jan. 1977). The auditor who detects such "irregularities" or who concludes that management "may have overridden control procedures" is under a duty to report its findings to "an appropriate level of management that is at least one level above those involved." STATEMENT ON AUdrING STandards No. 16, supra, fit 10, 14. If necessary, the auditor must make "the board of directors or its audit committee . . . aware of the circumstances." Id. Because Rule 202 of the AICPA's Code of Professional Ethics requires adherence to the auditing standards promulgated by the AICPA, a monitoring system now exists. However, its effect is largely short-circuited where there is no audit committee of outside directors to receive such information.

328 Report of Committee on Corporate Laws: Changes in the MBCA, supra note 34. See also Hawes \& Sherrard, Reliance on Advice of Counsel As a Defense in Corporate and Securities Cases, 62 VA. L. REv. 1, 70-72 (1976). Despite its recent vintage, Model Act section 35 has already been enacted in several jurisdictions, including California. See CAL. CoRP. CoDe $\S 309$ (West 1977). In New York, an amendment conforming section 717 of the Business Corporation Law to the revised version of section 35 was vetoed in 1975 , but was again passed and signed into law by Governor Carey late in 1977, despite the recommendation of the New York Attorney General that he veto it on the grounds that it went "beyond the current law" and did not require a director "to exercise diligence or skill in performing his duty." See Lefkowitz, Memorandum for the Governor Re: A. 245-B (June 29, 1977) (contained in the bill jacket and on file with the Virginia Law Review). The criticisms here expressed of this expanded reliance defense are not that it reduces the requisite level of skill expected of directors, but that it may absolve them in many instances from any responsibility to install monitoring systems.

329 Section 35 of the Model Business Corporation Act has three separate tests that must be met before its reliance defense will be upheld: (1) the directors must exercise a standard of due care defined basically as that of "an ordinarily prudent man in a like position ... under similar circumstances," (2) he must act "in good faith" and without "knowledge ... that would cause such reliance to be unwarranted," and (3) he must believe the person 
defense ${ }^{330}$ appears to permit corporate officials to rely on the subordinates' assurances that the corporation's hands are clean, notwithstanding the absence of any internal compliance system. ${ }^{331}$ Indeed, such a statute may create a disincentive for further inquiry by the board, because any such inquiry might turn up suspicious signs that would make reliance "unwarranted." ${ }^{332}$ In short, under such a system, ignorance is not only bliss, but for the liability conscious director it may be the prudent course.

\section{The Public Policy Doctrine}

One last possible theory of liability for the derivative suit plaintiff is the claim that corporate officials are liable for all losses resulting from actions that contravene public policy. Although this approach has lived more in academic commentary than in judicial decisions, three opinions applying New York law raise at least the possibility that the theory could be the basis for liability. The most important, Abrams $v$. Allen, ${ }^{333}$ involved the claim that the directors of Remington Rand had violated their fiduciary duties by deliberately relocating certain plants, in order to "intimidate" and "punish" employees for joining a union. Earlier decisions of the National Labor Relations Board and the Second Circuit had found the corporation to have engaged in unfair labor practices amounting to the classic "runaway shop." 334 However, the lower court had dismissed the derivative action, finding the defendants protected by the business judgment rule. ${ }^{335}$ The New York Court of Appeals reversed, stating that such actions by the defendant directors, if proved, "may be held to have amounted to actionable breaches of the duties owed by defendants to the corporation, as its trustees and agents." ${ }^{336}$ Then, in a statement upon which a legion of com-

on whom he relies to be "reliable and competent in the matters presented." ABA-ALI MOdel BUS. CoRP. ACT $\$ 35$ (Supp. 1977).

330 For an analysis of the more restrictive reliance defense statutes currently in effect, see Hawes \& Sherrard, supra note 328 , at $69-79$.

331 See Harris, supra note 126, at 1241 (questioning the wisdom of such an expansion of the reliance defense).

332 As discussed at note 329 supra, knowledge of contrary or inconsistent facts can make reliance "unwarranted" and the reliance defense unavailable under section 35.

333297 N.Y. 52, 74 N.E.2d 305 (1947).

334 NLRB v. Remington Rand, Inc., 94 F.2d 862 (2d Cir. 1938).

335271 App. Div. 326, 65 N.Y.S.2d 421 (1946).

336297 N.Y. at 55, 74 N.E.2d at 306. 
mentators has focused, the court added: "That the public policy of this State and nation is opposed to the closing or removal of factories, for such purposes as here asserted, is obvious." ${ }^{337}$ The contemporary reaction to this apparent rule that derivative suits could be based on public policy was both excited and symptomatic. Perhaps characteristically, student writers in the Harvard Law Review warned ominously that it would subject directors to domination by outside pressure groups, ${ }^{338}$ while the editors of the Yale Law Journal heralded it as offering a new means by which irresponsible corporations could be brought under greater social control. ${ }^{339}$

But did Abrams justify either this alarm or enthusiasm? ${ }^{340}$ The court interpreted the complaint as alleging that the acts in question were "not done for any legitimate business reason, but ... were done solely to discourage, intimidate and punish the corporation's employees." ${ }^{411}$ In particular, the court stressed the allegation that the principal defendant had dominated the board and forced it to permit him "to vent his personal bias, animus and hatred in evolving and executing the policy" of closing the corporation's factories. ${ }^{342}$ So construed, the wrong held actionable in Abrams seems based more on the misuse of the corporation as a vehicle for pursuit of a personal vendetta than on any broader theory of liability grounded in violations of public policy. Indeed, the decision's penultimate paragraph notes that the defendants could at trial rebut the plaintiff's allegations by showing that "they may have done [the wrongful acts] for the best of reasons." "343 This statement seems to suggest that a "legitimate business purpose" would immunize directors from liability for acts contrary to public policy, a proposition almost the converse of that for which Abrams has been cited.

While there are ambiguities in 'Abrams' holding, ${ }^{344}$ the interpre-

337 Id. at 56,74 N.E.2d at 307.

33861 Harv. L. REv. 541, 542 (1948).

339 Note, Use of the Derivative Suit by Groups Foreign to the Corporation to Prevent Corporate Violation of Law and Public Policy, 57 YALE L.J. 489 (1948).

340 For perhaps the best contemporary asessment of the case, see 15 U. CHI. L. REv. 423 (1948).

341297 N.Y. at 55, 74 N.E.2d at 306.

342 Id.

3.3 Id. at 56, 74 N.E.2d at 307.

344 See Note, Civil Responsibility for Corporate Political Expenditures, 20 U.C.L.A. L. REv. 1327, 1337 (1973), which suggests that it is arguable that a "legitimate" business pur- 
tation subsequently placed on the decision by the lower New York courts may be the best guide to its meaning. On remand, the lower court found that it was not clear that the plant closings were undertaken for other than legitimate business purposes, and it dismissed the complaint. ${ }^{345}$ Probably because of this anticlimactic denouement to Abrams, its putative principle that corporate officials are liable for acts in violation of public policy has lain dormant in New York. Moreover, courts in Delaware and California have expressly rejected the case's suggestion that courts may discover public policy limitations on the implied powers of corporate officials, holding that such a doctrine would amount to judicial usurpation of the legislature's prerogatives. ${ }^{\mathbf{3 4 6}}$

If the public policy doctrine experienced a still-born birth in Abrams, it may have been "born again" with Miller $v . A T \& T .{ }^{347}$ Miller held that corporate directors could not raise a business judgment defense to a derivative suit based on illegal corporate political contributions. This holding seems to rest upon two distinct grounds: its finding that plaintiffs were within the class protected by the statute, ${ }^{348}$ and its interpretation of the New York public policy doctrine. By beginning its analysis with Roth v. Robertson, ${ }^{349}$ the 1909 "hush money" case previously noted, the court in Miller was able to avoid the limitations inherent in Abrams. It focused on the stronger language in Roth and viewed Abrams merely as a reaffirmation of Roth's principle "that directors must be restrained from engaging in activities which are against public

pose cannot exist if action is contrary to public policy. However, such an analysis seems to ignore that it was not the effect of the plant closings, but the motivation behind them, that was asserted to be against public policy. Presumably, even under the most expansive reading of Abrams, the same action would be valid if undertaken for different reasons (i.e., to cut costs, which was tbe reason found on remand to be the actual motivation).

345113 N.Y.S.2d 181 (Sup. C.. 1952).

340 See Marsili v. Pacific Gas \& Elec. Co., 51 Cal. App. 3d 313, 124 Cal. Rptr. 313 (1975); Kelly v. Bell, 266 A.2d 878, 879 (Del. Sup. Ct. 1970), aff'g 254 A.2d 62 (Del. Ch. 1969) (stating that if certain tax payments violated public policy corporate officials would not be liable if they had "exercised honest business judgment"); cf. Hausman v. Buckley, 299 F.2d 696, 705-06 (2d Cir.) (applying New York law, court refused to substitute "public policy" for established conflict of laws principles), cert. denied, 369 U.S. 885 (1962). 347507 F.2d 759 (3d Cir. 1974) (discussed at text accompanying notes 232-35 supra). 348 See text accompanying note 234 supra.

34964 Misc. 343, 118 N.Y.S. 351 (1909) (discussed at text accompanying notes 250-51 supra). 
policy." ${ }^{350}$ Although this is a questionable progression, ${ }^{351}$ it is undeniably true that the Roth holding is broad and cannot be confined by limiting concepts such as that of "protected class." In Roth, the court wrote bluntly:

For reasons of public policy, we are clearly of the opinion that payments of corporate funds for such purposes as those disclosed in this case must be condemned, and officers of a corporation making them held to a strict accountability and be compelled to refund the amounts so wasted for the benefit of stockholders .... To hold any other rule would be establishing a dangerous precedent, and tacitly countenancing the wasting of corporate funds for purposes of corrupting public morals..$^{352}$

But, it is not clear that Miller resurrects Roth to such an extent that even legal conduct may be the basis for liability by virtue of being against public policy. Because Miller dealt with an alleged violation of a criminal statute, and the particular violation could exist only if "legitimate business justifications did not underlie the alleged inaction of the defendant directors," ${ }^{353}$ Miller need not be read so broadly.

Nonetheless, it might be. Despite the theoretical inability of federal courts to make substantive state corporate law, after Miller, it once again is conceivable that courts might hold corporate officials liable for acts taken in the corporation's interest that, although not unlawful, still offend a court's sense of morality or

350507 F.2d at 762.

351 It is questionable both because Abrams never cites Roth and because Roth's continuing relevance seems doubtful.

35264 Misc. at 346, 118 N.Y.S. at 353. Thus, given this strict construction of the statute, Miller's bottom line is 'much closer to the narrow interpretation of Abrams $v$. Allen suggested above than it is to Roth's expansive holding. Given that Miller requires the plaintiff to prove an absence of business justification, the question still left open by the decision is what constitutes a "legitimate business justification." For example, would fear of reprisal against the corporation justify non-collection of the outstanding debt? One recent derivative suit case has concluded that the plaintiff has the "burden of showing ulterior or wrongful directors' purposes lacking business justification" and that defendants may escape liability if they can show a "legitimate, if not compelling, business purpose for the transaction." See Heine v. The Signal Companies, [1976-1977 Transfer Binder] FED. SEC. L. REP. (CCH) If 95,898, at 91,317, 91,322 (S.D.N.Y. 1977). This suggests that where there is an overlap between a purpose that is offensive to public policy and one that is not, defendants will have an adequate defense, even if the Abrams doctrine is revised.

353507 F.2d at 765. 
public policy. Assuming that courts may have such a weapon within their reach to enforce higher standards of corporate morality, the next issue becomes unavoidable: should they use it?

Before the doctrine announced by Roth and exhumed by Miller is fully revived, however, some objections merit consideration which suggest that the judicial orphan discovered in the bullrushes by the Third Circuit in Miller is more likely to be Rosemary's Baby than the pathfinder to the promised land of corporate responsibility. These objections to this "public policy" approach materialize from at least four distinct perspectives. From an historical standpoint, the idea that public policy supplies sufficiently clear standards to justify retroactive imposition of liability upon corporate officials seems increasingly to belong to an earlier and simpler era, when it was easier to conceive of "public policy" as composed of a set of self-evident, generally accepted propositions. This platonic view of public policy seems untenable in today's world of competing policy goals, which more and more frequently show a tendency to come into conflict. For example, our national policy favoring the rapid development of energy resources coexists at best uneasily with our national policy of preserving the environment. Similarly, a corporation may violate public policy by failing to pursue affirmative action vigorously, while pursuing the same goals too vigorously may constitute reverse discrimination. Unavoidably, corporations live today in the crossfire of conflicting public policies. To place individual directors in this same exposed position is not only inequitable, but, given the rate of change in social mores, may subject them to what is essentially an ex post facto standard of accountability.

From the perspective of political science, a second objection to the doctrine is its casual disregard for the value of pluralism in our society. A number of commentators ${ }^{354}$ have suggested that the corporation as a major institution in our society must be recognized as a mainstay of its pluralism. By its existence, it decentralizes the exercise and accumulation of power within our society, affecting a degree of separation between economic and political decisionmaking. Whether this is desirable may, of course, be debated-

354 This "pluralism" theme has been ably articulated by Kingman Brewster. See Brewster, The Corporation and Economic Federalism, in THE CoRPORATION IN MODERN SocreTY 72, 75-76 (E. Mason ed. 1959). For a more recent example, see Eells, Foreword to C. Brown, supra note 9 , at xxii. 
although in the context of a post-Watergate society, such a separation of political and economic power may well represent one of the most important checks and balances on the ability of any group to monopolize power. In any event, while it may be irritating to some that those who possess economic power are not always easily amenable to majoritarian political controls, courts should be cautious before initiating on their own any significant alteration in the balance of power between the corporation and other countervailing forces. Other values hang in the balance. Yet, just such a realignment of that balance is precisely what the public policy doctrine would accomplish. By making directors individually liable under a vague and shifting standard of liability, special interest groups could, by making an insignificant investment in the corporation, threaten derivative litigation over any action that transgressed their conception of public policy. Even if we should discount the in terrorem effect of such a threat because of the probability that courts ultimately would interpret the public policy doctrine cautiously, there remains the likelihood that courts would only infrequently receive opportunities to supervise and domesticate their new doctrine. Strong incentives exist to settle shareholders' derivative litigation. ${ }^{355}$ Thus, the doctrine's real significance might lie, not in the power it would give courts, but in its threat potential, in the resulting leverage that it would give plaintiffs for settlement negotiations. The net effect might be comparable to the effect that would result from adopting the recent Nader proposals to grant seats on the board to these same special interests. ${ }^{356}$ The point here is not that corporations should be beyond public control, but that the kind of control which results

355 Under the Model Business Corporation Act, the settlement of a derivative suit does not require judicial approval, and such a settlement may provide for the payment by the corporation of the plaintiff's attorney's fees. ABA-ALI MoDEL Bus. CoRp. Acr $\S 5$ (1971). Such private settlements frequently are motivated by the coupled desires of the plaintiff's counsel for a substantial fee and of the defendants to avoid payment of a large settlement to the corporation. In addition under section $5(\mathrm{~b})$, if there is an out-of-court settlement, the corporation may indemnify the defendants for their expenses without court approval. Id.

356 While hard evidence is unavailable, it is noteworthy that observers have found most corporations shunning even permissible political activity in the wake of the recent spate of disclosure and lawsuits. See Bashful Business: Despite Liberal Laws Most Companies Shun "Partisan" Politicking, Wall St. J., Oct. 27, 1976, at 1, col. 1. It seems a likely inference that this tendency towards overcompensation would be greatly magnified were the "public policy doctrine" adopted. 
from the threat of litigation is itself perversely unaccountable because it is too invisible to be either measured or supervised. Among its roles, the corporation is society's advocate for the values of efficiency and an economically rational allocation of resources. To the extent that these values have to be subordinated to other, more human values (as at times they must), the balancing process should be open to public scrutiny and arrived at through the conflict of countervailing institutions (in part so that legislative modification of such compromises is possible). Yet what the public policy doctrine would essentially accomplish is to pit ideological plaintiffs against risk-averse defendants. Such a conflict is unequal because of the difference in motivations: having to choose between a trial and a settlement, the defendant director cannot be relied upon to fight. The result may be the same chilling effect upon the corporation's advocacy of efficiency that might result from the "politicalization" of the corporation.

The third perspective for criticizing the public policy approach is the traditional legalistic concern about usurpation of the legislature's function. Consider the example, suggested by one proponent of the public policy doctrine, of a court utilizing the doctrine to prohibit corporations from relocating their plants from urban areas to nonurban areas, because of the adverse impact of such movement on minority employment. ${ }^{357}$ In such an instance, a court would be confronted with a plea for private subsidization of a public goal (i.e., the alleviation of minority unemployment) based on an inference of public policy that the court is asked to derive from imprecise congressional and administrative pronouncements on employment discrimination. Arguably, directors should (and sometimes clearly do) weigh such public policy considerations, but before a court either requires, or holds them liable for declining to grant, such a private subsidy, it should consider two objections. First, because the costs of such a subsidy are likely to be reflected in higher prices, this example again reminds us of the invisibility of the process by which directors might be deterred from acting in what they considered to be the corporation's best interests. Accountability is nowhere more lacking than under a system where neither a court nor the legislature is in a position to assure itself that the costs of the subsidy do not outweigh its bene-

357 Friedman, The Public Interest Derivative Suit: A Proposal for Enforcing Corporate Responsibility, 24 CASE W. REs. L. REv. 294, 310-11 (1973). 
fits. Moreover, it would be simplistic to portray the conflicting interests implicated by such an assertion of the public policy doctrine as simply those of the corporation in profit maximization versus those of the society in attaining the public goal of greater minority employment. Society is not that monolithic; the interests of consumers, of creditors, of the rural areas that would receive the enhanced employment are all involved and yet unrepresented when decisions are made based on the threat of litigation. Secondly, the more aggressive proponents of the public policy doctrine employ a dubious assumption that when the legislature spoke in a limited fashion to a problem, it simply overlooked the possibilities for more thorough-going reform. In truth, of course, legislatures often find piecemeal reforms the better part of political valor, and the toleration of even obvious inconsistencies can be at the heart of a political compromise. Thus, by extrapolating broad and specific rules from vague statements of legislative purpose, the public policy doctrine reverses the normal rules of statutory construction that, if anything, a negative inference should result from a precise, but limited, legislative pronouncement.

A final criticism emerges from the perspective of organization theory. If it is clear that difficult decisions are often avoided by everyone within a hierarchy, the strong tendency in uncertain circumstances being to delegate, ${ }^{358}$ then the policy implication of this observation is that a belief among board members that all issues of public policy were referrable to a court for resolution actually would hamper the development of a greater awareness and sense of responsibility by the board. In addition, permitting public interest plaintiffs to take all such issues to court might prompt the board to view decisions with an eye toward their appearance in future litigation. Once this happens, substance yields to cosmetics, and we have installed not a stronger superego, but only an additional public relations arm.

\section{A Preliminary Evaluation}

With our scouting trip into the thicket of the common law now half complete, it is time to take an initial inventory. We have encountered several theories by which shareholders' derivative suits could redress corporate misconduct, although each involves signifi-

358 W. MorRIs, supra note 1 , at 53. 
cant doctrinal obstacles. Courts could (l) declare any statutory violation to be a per se breach of fiduciary duty, (2) impose on corporate officers a comprehensive duty to disclose such misconduct to the board, (3) require through negligence theories that corporate officials develop adequate internal monitoring systems, or (4) adopt the public policy doctrine foreshadowed by Miller.

But should they? Here, it is useful to return to our earlier dichotomy of "moralistic" versus "pragmatic" legal responses. While the monitoring and disclosure duties would involve pragmatic organizational changes, the strict liability and public policy strategies are essentially substantive and "moralistic." The first priority of these moralistic theories is to condemn illicit conduct, regardless of whether condemnation will prevent it. Without restating the arguments made earlier, it seems fair to say that these latter approaches ignore the organizational subtleties of the modern large corporation.

In addition, a basic choice arising here is whether we want to assign the primary responsibility for policing corporate misconduct to the board or to the shareholder. Maximizing the shareholder's role, through approaches such as the public policy doctrine, may well correspondingly weaken the board's role. Strengthening the shareholder's litigating posture may diminish what is potentially the strongest positive incentive the board has to dissolve information blockages: its authority to reject derivative litigation as not in the best interest of the corporation..$^{359}$ The two roles are not mutually exclusive, but a primacy must be assigned. Clearly, "moralistic" approaches favor the shareholder-based model, while the other approaches place principal reliance upon the board as the corporation's embryonic superego.

If one accepts this premise that a conscious choice must be made between a shareholder-based and a board-based model of corporate accountability, then organization theory suggests that the board model be given relative priority, because the board is far better situated and equipped to monitor. Although from the standpoint of fiduciary ideology the stockholder is the beneficiary whose rights the system is designed to protect (and hence is the appropriate vehicle for enforcing greater corporate responsibility), the picture is quite different when seen from the empirical per-

359 See text accompanying note 448 infra. 
spective of those who have studied behavior in large organizations. Viewed from this angle, the stockholder becomes an outsider, a stranger whose interference those within the system will resent, and a force too remote in terms of organizational distance to monitor effectively. Indeed, Williamson's central contention is that the modern corporation has already developed its own system of internal self-discipline (based principally on the auditing and capital allocation powers of senior management), one that outperforms even the discipline that the marketplace can provide. ${ }^{360}$ For our purposes, the problem is how to transfer sufficient control over this capability from senior management to an independent board.

\section{Corporate Counsel Rebuts: A Survey of the Defenses}

In response to the foregoing theories of liability available to a plaintiff stockholder challenging alleged corporate misconduct, a defendant director might raise a number of defenses. These include (1) the "good faith" defense of reliance upon counsel's advice; (2) the defense of "duress"; (3) the defense of proximate causation and, in particular, the New York "net loss" rule; and (4) the "business judgment" defense that arises when "independent" directors decide that it is not in the corporation's best interests to pursue litigation against allegedly errant employees. ${ }^{361}$ This section will examine each of these in turn, considering its common-law basis, its utility in terms of our earlier diagnosis of corporate malfunctioning, and any appropriate limiting conditions within the reach of the common law that might be placed on these defenses in order to enhance our ability to influence organizational behavior.

1. The Defense of Reliance upon Counsel Versus the "Duty to Disclose"

A corporate official who takes action in reliance upon counsel's advice that the action is permissible currently is relatively immune

360 See Markets and Hierarchies, supra note 1, at xv-xvii, 137-48.

361 Calling these legal doctrines "defenses" is technically incorrect, because in several instances they involve issues for which the plaintiff has the burden of proof in order to establish a prima facie case. Nevertheless, they are legal arguments that defendant directors predictably will raise either to justify or to exculpate themselves when corporate misconduct has been found. 
from attack by a shareholder's derivative suit. ${ }^{362}$ As courts are fond of saying, directors are not insurers.

The defense, however, is not available every time a corporate official violates a law in reliance on the advice of a lawyer. A recent comprehensive survey of cases discussing such reliance has concluded that to make out the defense, the defendant must prove: (1) that the defendants reasonably believed counsel to be competent in the area covered by the advice; (2) that counsel received full disclosure of the relevant facts; (3) that the advice pertained to matters of law and was not general business advice; and (4) that the defendants in fact relied upon the advice. ${ }^{363}$ These principles indicate that reliance upon counsel will not always prevail as a defense in the corporate misconduct context. Some misconduct cases are likely to involve a corporate official who either relied upon an attorney inexperienced in the relevant area of the law, failed to inform the attorney of all the embarrassing details, sought the advice only after a final decision had been made, relied upon casual advice, or engaged in counsel shopping until he received the desired advice.

Still, the foregoing limitations do not appear to represent major inroads on the defense. Unfortunately, it is exactly in the most egregious cases, where the client has a cooperative counsel willing to engage in the necessary charade, that the defense seems the most easily invoked. Thus, because the reliance upon counsel defense enables one private party to exculpate another from civil liability, a potential for abuse clearly exists. Recent judicial decisions have indicated the possibility of a fifth limitation on the defense, one which partially responds to this potential for abuse: a requirement that the advising attorney not be known to be subject to a conflict of interest.

362 See Pool v. Pool, 22 So. 2d 131 (La. App. 1945); Blaustein v. Pan American Petroleum \& Transp. Co., 293 N.Y. 281, 56 N.E.2d 705 (1944); Gilbert v. Burnside, 13 App. Div. 2d 982, 216 N.Y.S.2d 10 (1961), aff'd, 11 N.Y.2d 960, 183 N.E.2d 325, 229 N.Y.S.2d 325 (1962); Simon v. Socony-Vacuum Oil Co., 179 Misc. 202, 38 N.Y.S.2d 270 (1942), aff'd mem., 267 App. Div. 890, 47 N.Y.S.2d 589 (1944); Hawes \& Sherrard, supra note 328. Most of these cases have involved alleged violations of the duty of due care in committing the corporation to an illegal course of action. The courts have upheld the defense even though the corporation itself would not have invoked it, because the statutes violated (typically the antitrust laws) required no element of willfulness. The defense has also been recognized where the alleged fiduciary breach involved the duty of loyalty. See, e.g., Spirt v. Bechtel, 232 F.2d 241 (2d Cir. 1956).

363 See Hawes \& Sherrard, supra note 328, at 19-37. 
In Fogel $v$. Chestnutt, ${ }^{364}$ the Second Circuit confronted the same conflict of interest issue present in Moses $v$. Burgin: ${ }^{365}$ whether a mutual fund investment adviser had a duty to seek recapture of brokerage commissions. In Fogel, the board of the fund did not seek recapture, relying upon the opinion of the investment adviser's house counsel that the recapture would have violated applicable stock exchange rules. The advising attorney was house counsel, officer, director, and part owner of the investment adviser, which would have been injured by such a recapture policy. In a subsequent shareholders' derivative suit challenging this decision, when the defendants asserted the defense of reliance upon counsel, the Second Circuit denied the defense because of the attorney's conflict of interest. The court's refusal to protect reliance upon advice from such an interested source is consistent with the traditional limitations on the defense, which stem from the recognition that reasonable people do not rely on such self-serving advice. ${ }^{366}$

Although Fogel can be limited to its fact situation of a highly partisan source, the subsequent case of Papilsky $v$. Berndt ${ }^{367}$ cannot be confined so easily in its holding. Papilsky involved virtually the same facts as Fogel, except that the legal advice relied upon came not from a dubious source, but from a distinguished New York law firm. Further, the advice was not equivocal. Judge Frankel characterized it as both "adamant" and given in "earnest good faith." ${ }^{668}$ In rejecting the reliance upon counsel defense, he noted first that the law firm, by representing both the adviser and the mutual fund, "was counseling people with contrary interests." ${ }^{369}$ Second, he noted that the defendants had orchestrated carefully the timing and manner of presentation of its legal advice, so as to reinforce their own business advice against seeking recap-

364533 F.2d 731 (2d Cir. 1975), cert. denied, 429 U.S. 824 (1976).

305445 F.2d 369 (Ist Cir.), cert. denied, 404 U.S. 994 (1971). Moses is discussed at text accompanying notes 266-69 supra.

366 In other words, both the "reliance" and the "competent counsel" elements of the defense were lacking. See SEC v. Culpepper, 270 F.2d 241, 250-51 (2d Cir. 1959); Hawes \& Sherrard, supra note 328, at 20-29, 35-36. In Fogel, the Second Circuit suggested that the "investigation of ... legal consequences" should have been performed by "disinterested counsel furnished to the independent directors." $533 \mathrm{~F} .2 \mathrm{~d}$ at 750 .

367 [1976-1977 Transfer Binder] Fed. SEc. L. REP. (CCH) I 95,627 (S.D.N.Y. 1976).

368 Id. at 90,133. However, Judge Frankel also characterized the advice as "inadequate," because of its "exceedingly 'casual'" nature.

369 Id. 
ture $^{\text {370 }}$ Arguably then, Papilsky expands the Fogel rule so that it is applicable not simply to the infrequent fact situation of a financially interested counsel, but also to the recurring situation of a counsel subject to a conflict of interests.

It would be tempting to discover a new lever for reform by framing the rule that emerges from these cases to be that reliance on advice from a counsel known to the recipient to be subject to a conflict of interest will not give rise to a valid defense. But, such a rule seems too broad. Although language in Fogel discredits reliance on advice "from a lawyer having a personal stake adverse to the shareholders," "371 the dimensions of this "personal stake" test are uncertain and potentially greater than the court intended. For example, it is difficult to distinguish meaningfully the "personal stake" of a lawyer-stockholder in his investment from the "personal stake" of a house counsel in his future employment or an outside counsel in future fees, both of which may depend on the corporate official who desires a favorable opinion. Economically, the counsel in Fogel (who appears to have been an investor of some means) was probably more independent than the typical assistant house counsel, who may feel pressure to deliver a favorable opinion that will immunize his superiors.

If this conflict of interest limitation on the reliance upon counsel defense is inappropriate, how should Fogel and Papilsky be interpreted? A narrower interpretation of these cases begins at the starting point supplied by Moses $v$. Burgin: "inside" directors and other corporate officers owe a "duty of full disclosure of information" to the independent members of the board "in every area where there [is] even a possible conflict of interest between their interests and the interests of the fund." ${ }^{372}$ As an element of this duty of full disclosure in conflict situations, Moses identified an obligation of "effective communication." ${ }^{373}$ Fogel defined this obligation as a duty to investigate all possible courses of action with "an eye eager to discern them rather than shut against them." 374

370 Id. at 90,133-35. The action against the unaffiliated directors in Papilsky had already been dismissed on procedural grounds. Id. at 90,122. The court thereby avoided the question of whether outside directors could be held liable because of inadequate legal advice to them. Suggestively, the case against the outside directors similarly was dismissed in Moses v. Burgin. See 445 F.2d at 384.

371533 F.2d at 749 .

372445 F.2d at 376.

373 Id. at 377.

374533 F.2d at 749 . 
Against this backdrop, both Fogel and Papilsky appear to say that even if the board is receiving competent legal advice, the inside directors and other corporate officers have an obligation to communicate the opposing views of the SEC and the stock exchanges so as not to "discourage any independent inquiry" by the unaffiliated directors. In this light, the holding of these cases may have less to do with the problem of biased legal advice than with the limited relevance of reliance upon counsel as a defense to a breach of the duty to "effectively communicate" all possible options to the board.

This latter interpretation of Fogel and Papilsky finds support in subsequent cases that seem to have retreated from the suggestion that a conflict on the attorney's part can preclude reliance on his advice. Tannenbaum v. Zeller ${ }^{375}$ presented the Second Circuit with a situation identical to Fogel, except that the law firm's opinion letter advising that the board could forego recapture also fairly summarized the contrary views of the SEC and the stock exchanges. In holding that this constituted "effective communication," the court stated that " $[t]$ he fact that counsel were not disinterested does not violate the reasonableness of the judgment which the independent directors reached here." 376

In sum, when corporate officers have the duty to effectively communicate all options to the board, it would seem that reliance upon counsel supplies adequate justification for nondisclosure to outside directors only in those rare instances in which counsel's advice proves false because of a sudden and unexpected change in the law. When, however, a transition in the law is foreshadowed by the usual storm signals of legal change, the defense of reliance upon counsel should not be available to corporate insiders in conflict situations who are aware of those signals, because evaluation of competing legal theories is a task for the independent members of the board (and their special counsel) to perform. ${ }^{377}$

375 [1976-1977 Transfer Binder] Fed. Sec. L. Rep. (CCH) If 95,900 (2d Cir. 1977).

$378 I d$. at 91,345 . In an amicus brief, the SEC, while critical of some of the reasons advanced by the directors, also concluded that the judgment had been reasonable under all the circumstances. See also Lasker v. Burks, 426 F. Supp. 844, 851 (S.D.N.Y. 1977) (distinguishing Papilsky and approving of an attorney serving as one of the special counsel to the independent directors, although the attorney was technically an "interested person" under section 2 of the Investment Company Act of 1940, 15 U.S.G. $\S 80$ a-2(a)(19)(A)(iv) (1970), because of his firm's recent representation of the fund).

377 To a considerable extent the debate between the private bar and the SEC during the late 1960 's and early 1970 's over the necessity of brokerage recapture resembles the 
But when does this duty of effective communication arise? The conservative interpretation is that the basis for Moses v. Burgin and its progeny was the special provisions of the Investment Company Act of 1940, which essentially create a federal law of fiduciary duties uniquely applicable to investment companies. ${ }^{378} \mathrm{But}$ this narrow interpretation seems incomplete. Three distinct theories support extending the duty to communicate effectively from investment companies to other publicly held corporations.

First, Moses v. Burgin did not assume that the duty to disclose was a special creation of the Investment Company Act, unknown to the common law. The case actually assumed that the majority rule under the common law probably would produce an equivalent result. ${ }^{379}$ Support for such a common-law rule is not hard to find. ${ }^{\mathbf{3 8 0}}$ To be sure, all of the investment company cases from Moses to Tannenbaum have emphasized the special nature of investment companies and their greater opportunities for conflicts of interest and self-dealing. ${ }^{381}$ But, this factor should only heighten the duty

current debate between the same parties over the materiality of improper corporate ac. tivities. This being so, "inside" corporate officials seeking a release, ratification, or decision not to sue from their own boards of directors might be found to have the same duty of "effective communication." And, for counsel's advice to provide a defense, it may have to sunmmarize adequately the opposing arguments.

378 Both the First Circuit in Moses and the Second Circuit in Fogel and Tannenbaum have relied upon two provisions of the Investment Company Act, 15 U.S.C. $\$ \S 80 \mathrm{a}-1$ to -52 (1970 \& Supp. V 1975), for this principle: (1) section 10, 15 U.S.C. $\$ 80 \mathrm{a}-10$ (1970), which requires that not less than $40 \%$ of the board of an investment company be composed of "non-interested" persons; and (2) section 36, 15 U.S.C. $\S 80 \mathrm{a}-35$ (1970), authorizing federal courts to grant civil recovery for "breach of fiduciary duty involving personal misconduct." With respect to the duty of disclosure, primary reliance has been placed on section 10. See Tannenbaum v. Zeller, [1976-1977 Transfer Binder] Fed. SEc. L. Rep. (CCH) If 95,900 (2d Cir. 1977); Moses v. Burgin, 445 F.2d 369, 376-77 (1st Cir.), cert. denied, 404 US. 994 (1971). Both circuits agreed that the purpose of the unaffiliated director requirement of the Investment Company Act would be "subverted" if the unaffiliated directors were not furnished with sufficient information to enable them to participate effectively in the management of the investment company. This theory dates back to an earlier SEC decision, Imperial Financial Services, Inc., [1964-1966 Transfer Binder] FED. SEc. L. REP. (CCH) If 77,287, at 82,464 (SEC 1965).

379 In Moses, the First Circuit noted that a conflict of interest "routinely calls for disclosure quite apart from any special burden that may be implicit in the Investment Company Act." 445 F.2d at 383. In this light, the effect of the Investment Company Act was largely to eliminate the possibility that Massachusetts law might have produced a different result, given its hostility to derivative suits. The court found that section 36 of the Act gave federal courts jurisdiction to enforce federal standards. Id. at 373.

380 See, e.g., cases cited at note 270 supra.

381 See, e.g., $445 \mathrm{~F} .2 \mathrm{~d}$ at 376 (noting that "self-dealing is not the exception but . . the order of the day"); Tannenbaum v. Zeller, [1976-I977 Transfer Binder] Fed. SEc. L. REP. 
and not create it. In addition, in the wake of the illegal payments reports, revelations of self-dealing have surfaced with such frequency ${ }^{382}$ that today there is less reason to view investment companies as unique. Even if the concept of conflict of interest is given a narrow definition in terms of existing or contingent liabilities to the corporation, it is clear that an employee who recklessly or negligently undertakes an illegal act on behalf of a corporation may be liable to the corporation for resultant losses. Once this is said, the failure to disclose to the board can itself be viewed as a decision in which the employee has a conflict of interests (stemming from a desire to hide his contingent liability) ${ }^{383}$ Because the majority of

(CCH) If 95,900, at 91,327; Mundheim, Some Thoughts on the Duties and Responsibilities of Unaffiliated Directors of Mutual Funds, 115 U. PA. L. REv. 1058, 1059-60 (1967).

382 Several recent SEC enforcement actions have shown corporate officials to be receiving undisclosed income and fringe benefits from their corporations. Those Business Payoffs Didn't All Go Abroad; Bosses Got Some Too, Wall St. J., May 2, 1977, at 1, col. 6. See also SEC v. Potter Instrument Co., [1976-1977 Transfer Binder] FED. SEC. L. REP. (CCH) If 95,924 (D.D.C. 1977).

383 One recent decision may seem at first glance to challenge this generalization that the nondisclosure of a corporate official's involvement in misconduct gives rise to a conflict between his interests and those oi the corporation (which might then trigger the rule of Moses v. Burgin). In Falkenberg v. Baldwin, [1977 Current Binder] FED. SEC. L. REP. (CCH) If 96,086, at 91,911 (S.D.N.Y. 1977), the plaintiffs in a derivative suit against officials and auditors of Uniroyal, Inc. alleged that nondisclosure of illegal payments and of a pattern of sex discrimination at one plant created a conflict of interests between the defendants and the corporation. The court began its analysis by recognizing the significance of such a conflict: "In the ordinary situation, the knowledge of the board of directors or officers provides the protection to the shareholders against the kind of fraud the securities laws proscribe. Such protection is nonexistent, however, if a conflict of interest impedes the flow of information." Id. at 91,911. On the facts pleaded, however, the court said no such conflict existed, since the "only possible 'interest' alleged on the part of the officers or directors is a desire to remain in office." $I d$. Then it added: "This interest may be attributed universally to boards of directors and officers of corporations and is not a basis for a claim of conflict with the interests of the corporation." Id.

Is the conflict of interest that we are postulating here similarly "universal" and at bottom based on nothing more than the desire to stay in office? For two reasons, the opinion in Falkenberg indicates that that court would not have reached such a result in our context. First, in contrast to Falkenberg, where the court found no "pecuniary interest" involved, there is certainly a real threat of liability of the official to the corporation when, through negligence or poor judgment, he exposes it to a penalty or loss. Second, and more importantly, all the directors in Falkenberg were found to have been aware of the circumstances surrounding the alleged misconduct. The issue there was the almost metaphysical one of whether their knowledge could be imputed to the company; if it could not, the corporation arguably had a cause of action under rule $10 \mathrm{~b}-5$, which then could be asserted by the derivative suit plaintiff. In our proposed case, however, the official has withheld information from the board, in part for a pecuniary motive; thus, in the Falkenberg court's phrase, he has "imped[ed] the flow of information" and has 
illegal payments cases thus seem to involve conflicts of interest, the presumption of Moses, that if disclosure had been made to it the board would have acted differently, can be stretched to apply.

A second theory for the extension of Moses $v$. Burgin's rule is that of implied representation. Although the requirement of the Investment Company Act of 1940 that a mutual fund's board contain a requisite percentage of "non-interested" directors is a unique legislative rule, prevailing practice among large public corporations has caught up to and even surpassed this standard. Today, a majority of public corporations have boards with a majority of "outside" directors. ${ }^{384}$ This development should have legal significance. With the voluntary adoption of such a precautionary measure should come the imposition by estoppel of the duty of "effective communication," which Moses implied accompanied the legislative requirement of an outside presence. Outside directors serve, as Professor Bishop once ascerbically phrased it, as "decoy ducks;" ${ }^{385}$ by their presence, investors are lured into having confidence in the corporation. If one accepts this premise, then an estoppel concept seems appropriate. Because by installing an independent board management impliedly represents to investors that "outsiders" are in control, this implied representation should be made binding by judicial recognition of a duty to "effectively communicate." With the benefits should come the burdens.

Finally, a third theory supporting the same result is appearing on the long-term horizon. To the extent that the rule in Moses, Fogel, Papilsky, and Tannenbaum is based on implicit federal fiduciary standards, those standards soon may be generalized to cover all public corporations listed on stock exchanges. The SEC has begun to prod the New York Stock Exchange to consider an "indepen-. dent" board requirement for listing eligibility. ${ }^{386}$ If the Exchange

undercut the shareholder's normal means of "protection ... against the kind of fraud the securities laws proscribe." Id.

384 The most recent extensive study of board composition was conducted by Heidrick and Struggles, a management consulting firm, in September, 1976. Surveying the 1,000 largest United States industrial corporations, it found that more than two-thirds of the boards were composed of a majority of outsiders, and that the trend towards "outside" majorities was increasing. Heidrick and Strugcles, Inc., The Changing Board: Profile of the Board of Directors 6 (1977) [hereinafter cited as The Changing Board].

385 Bishop, supra note 16 , at 1092 .

386 On May II, 1976, SEC Chairman Roderick Hills wrote New York Stock Exchange President William Batten to suggest amendment of the Exchange"s listing policies to increase the role and percentage of "outside directors on publicly Jisted companies." SEC 
eventually adopts a rule requiring a majority of the board to be "outsiders," its approval by the SEC, pursuant to that agency's authority under the Securities Exchange Act of 1934, ${ }^{387}$ should provide the same legal foundation for imposing the "duty to disclose" as did the statutory requirement, under the Investment Company Act of 1940, that a lesser percentage of a mutual fund's board be "non-interested." ${ }^{388}$ Because the federal securities laws contemplate an integrated system of regulation, these two statutes should be construed in pari materia and the same inferences drawn from the requirement of disinterested directors. Both statutes impose the requirement to protect shareholders, and in neither case is the rule effective unless management is forced in conflict situations to disclose fully to the board.

If this "outside" board requirement is adopted, it should be enforceable by shareholders' derivative suits. Some authority indicates that shareholders may sue directly for breach of a stock exchange rule that injures them. ${ }^{389}$ The arguments for implying such a cause of action are strongest where, as here, the stock exchange rule (1) is a "substitute" for direct SEG regulation, (2) imposes a duty unknown to the common law, and (3) is intended to protect a class of persons that includes the stockholder-plaintiff. ${ }^{390}$ But the potentially complex issue of implied causes of actions under stock exchange rules does not truly arise here, because the better view, adopted by most commentators, is that even a state court hearing a conventional derivative suit must recognize applicable federal fiduciary standards in measuring the fiduciary obligations of the defendants. ${ }^{391}$

PAYMents RePort, supra note 2, Exhibit D. Testifying before a Senate Committee on June 21, 1976, Hills indicated more specifically that he, and presumably the SEC, favor a majority "outside" board. See [1976-1977 Transfer Binder] FED. SEC. L. REP. (CCH) If 80,611 (June 21, 1976).

387 Such SEC approval is required by section $19 \mathrm{~b}$ of the Securities Exchange Act of 1934. See 15 U.S.C. $\$ 78 \mathrm{~s}(\mathrm{~b})$ (Supp. $\mathrm{V}$ 1975).

388 I5 U.S.C. $\$ 80 \mathrm{a}-10$ (1970 \& Supp. V 1975).

389 See Van Gemert v. Boeing Co., 520 F.2d 1373 (2d Cir. 1975); Colonial Realty Corp. v. Bache \& Co., 858 F.2d 178, 182 (2d Cir.), cert. denied, 385 U.S. 817 (1966). For a discussion of these cases, see note 613 infra.

390 See note 613 infra.

391 See 59 Mich. L. Rev. 904, 912-14, 919-29 (1961). As this comment points out, this issue has arisen most often in the context of antitrust derivative suits seeking to recover from corporate officials compensation for the damages assessed against the corporation. However, in this respect there appears to be little difference between the 
In summary, the reliance on counsel defense should be available in general. But it is possible that courts could develop a partially countervailing doctrine: persons subject to a "conflict" have a duty to disclose all relevant information to the board to avoid a conclusive presumption that the board would have acted differently. Where such a duty applies, and disclosure is not made, the reliance upon counsel defense should be rejected. If the concept of "conflict" can be broadened to include, for example, the case of the corporate president who has made illegal payments and never disclosed them to the board, ${ }^{392}$ then we have a legal strategy that forces information to the top.

\section{The Duress Defense: The Corporation As Victim}

In 1936, Paramount Pictures had just emerged from a bankruptcy reorganization and faced a shaky future, particularly in its troubled labor relations. ${ }^{393}$ Early in 1936, however, a new labor agreement was reached, averting a paralyzing strike. But soon afterwards a union official named Bioff approached Keough, a senior officer of Paramount, to demand a substantial payoff for himself and other union officials, threatening that otherwise Paramount would be crippled by strikes. On investigation, Keough found that other major movie companies also had been approached and had agreed to comply, that Bioff "was reputed to be a member of Al Capone's gang," ${ }^{394}$ and that a year earlier a rejection of Bioff's demands had led to serious industry-wide labor unrest in the Midwest, resulting in the extended closings of many theaters.

federal standards contained in the antitrust laws and the federal standards contained in the securities laws. While both sets of statutes confer exclusive jurisdiction on the federal courts, they also give content to the concept of fiduciary duty as it is to be measured by state courts having jurisdiction from another source.

392 Such a corporate official would have a conflict to the extent that his acts are unauthorized or negligent, and create undisclosed contingent liabilities for the corporation. The officer's personal interest would be to resist disclosure of these acts to the hoard, which may have a valid cause of action against him or may wish to remove him because of the acts.

On a more theoretical level, the findings of Professors Maccoby and Bower indicate that such risky decisions inherently involve a conflict between the careerist perspective of the corporate manager, whose primary concern is short-term success, and the long-term orientation of the more risk-averse reasonable investor. See note 13 supra.

393 The fact pattern being described is from Hornstein v. Paramount Pictures, Inc., 22 Misc. 2d 996, 37 N.Y.S.2d 404 (1942), aff'd, 292 N.Y. 468, 55 N.E.2d 740 (1944).

39422 Misc. 2 d at 999,37 N.Y.S.2d at 409. 
Paramount management therefore complied with the demand after negotiating a $50 \%$ reduction in the payoff. The Paramount board (of which Keough was a member) did not learn of these developments until four years later, when Bioff and his confederates were indicted for labor racketeering. Minority stockholders then commenced a derivative suit, alleging that the payoff was a diversion of corporate funds from legitimate corporate purposes and violated a New York statute prohibiting bribes to labor union officials.

The decision of the New York Supreme Court in that case, Hornstein v. Paramount Pictures, Inc. ${ }^{395}$ reached a number of conclusions that have considerable relevance to contemporary situations such as the Gulf Oil paradigm. First, the court found the crime of bribery to have two essential elements: (I) a "voluntary" giving of something of value, and (2) an intent "to influence the performance of [an] official duty." ${ }^{396}$ Finding Bioff to have been an "extortioner" rather than "the acceptor of a bribe," ${ }^{397}$ the court ruled that the first element of voluntariness had been lacking. But even if it had been present, the court added that the second element of an attempt to influence an official duty was missing, because Bioff had approached the corporation in a private capacity, not "in the performance of any duty as a representative of the labor union." 398 Finally, turning to plaintiff's last argument that even "submission to an illegal exaction" was "contrary to public policy" because it encouraged further such demands, the court squarely rejected the idea that the corporation had a public duty to resist illegal demands:

To say that to permit corporate officers to use corporate funds to buy off racketeers is contrary to public policy because likely to produce or increase racketeering is appealing to one's sense of moral principles, but as applied to this case it involves the fallacious assumptions that business corporations owe a duty to the public to prevent racketeering at their own expense and that corporate officers are bound to observe that duty to the public even though it cause the loss of all the corporate funds committed to their charge. I do not

39522 Misc. 2d 996, 37 N.Y.S.2d 404 (1942), aff'd, 292 N.Y. 468, 55 N.E.2d 740 (1944).

396 Id. at 1003,37 N.Y.S.2d at 413.

397 Id. at 1004,37 N.Y.S.2d at 413.

398 Id. 
think it can be said that public policy requires that corporate officers be thus required to serve two masters. ${ }^{399}$

Hornstein appears then to stand for three propositions that together provide substantial protection for the corporate executive. First, submission to extortion under duress makes the corporation a victim, not a coconspirator. Hornstein's liberal definition of duress is particularly important here. Borrowing from contract law, the court adopted a definition of duress that not only includes economic pressure, but suggests that the requisite quantum of economic pressure exists whenever there is "fear that otherwise [the submitter] would suffer a greater detriment." ${ }^{400}$ Whether the corporation should yield or should offer "stout resistance" was seen as a decision protected by the business judgment rule. ${ }^{401}$ Second, the "official duty" limitation in Hornstein would exculpate even voluntary payments. For example, a payment by a Lockheed official to a Middle East defense minister having procurement responsibilities would constitute bribery under this test, while a payment

399 Id. at 1006,37 N.Y.S.2d at 415 . The court added that submission to such demands made the corporation the "victim," not the wrongdoer. Because the court's construction of the statute led to a finding of no violation, Hornstein is not literally a case of knowing illegality.

The lower court opinion suggests one other exculpatory concept. Paramount, it said, "did not violate any law of the State governing Paramount's existence." Id. (emphasis added). This suggests that only some statutes limit the corporation's authority. The same theory was put forth in Simon v. Socony-Vacuum Oil Co., 179 Misc. 202, 38 N.Y.S.2d 270 (1942), aff'd mem., 267 App. Div. 890, 47 N.Y.S.2d 589 (1944) (discussed at pages 1175-77 supra).

40022 Misc. 2d at 1006, 37 N.Y.S.2d at 415 (quoting Berg v. Hoffman, 275 N.Y. 132, 134, 9 N.E.2d 806, 808 (1937)). Elsewhere, after citing Williston on Contracts, the court added that "[t]he characteristic of duress is that the choice is made of the lesser of two evils." Id. at 1008, 37 N.Y.S.2d at 417 (citing Union Pac. R.R. v. Public Serv. Comm'n, 248 U.S. 67, 70 (1918)).

$401 \mathrm{Id}$. at 1007, 37 N.Y.S.2d at 417 . The court added, however, that "abuses of discretion" could be reviewed.

This resort to contract law principles and the business judgment rule on an issue of criminal law is probably the weakest aspect of Hornstein, given the existence in the New York criminal code of a specific duress defense provision that defines duress more narrowly in terms of yielding to physical force. See N.Y. Penal Law $\$ 40.00$ (McKinney 1975). That provision now permits an affirmative defense that the defendant was coerced "by the use or threatened imminent use of unlawful physical force ...., which force or threatened force a person of reasonable firmness in his situation would have been unable to resist." $I d$. At the time Hornstein was decided, the immediate predecessor of this section required a showing of "instant death or grievous bodily harm." See id., Practice Commentary. 
to a politician having no official role in procurement, but possessing the de facto power and willingness to block or delay the contract unless paid off, might constitute submission to extortion. Third, the idea that a corporation has no greater obligation to resist extortion than a private citizen has to resist blackmail or usury raises the most sensitive public policy issue touched upon by Hornstein. If such a principle is unconfined, corporations might find the best approach to be to yield coyly, after the requisite formality of a pro forma protest. In addition, if the duress defense were so easy to invoke, it could be combined with the reliance upon counsel defense to provide a potentially ironclad protection. Under the reliance defense, the opinion of an independent, fully informed counsel that duress rendered a payment not unlawful would provide an additional penumbra of protection, even when the payment did not in fact meet Hornstein's test.

Although the preceding analysis might suggest 'that Hornstein should be limited, it is difficult to read the case without some sympathy for the position of Keough, as well as a sense that at some point the duress defense should be available to corporations. To be sure, a large corporation does not much resemble the widows and orphans who are the typical objects of judicial benevolence. But the injury to a corporation that is unfairly prevented from conducting its business eventually passes to its stockholders, employees, creditors, suppliers, and customers, all of whom deserve protection. The ripple effect of even one major corporate bankruptcy can be far-reaching. Thus, even if we recognize that directors are expected to serve as quasi-trustees for a broader constituency than simply stockholders, the interests of that broader constituency of employees, creditors, suppliers, and customers seem similarly allied.

Where then should the watershed lie in applying Hornstein? On its facts the case seems correct: faced with insolvency and threatened by a gangster, a corporation should have authority to make a "questionable payment," and ambiguous penal statutes should not be stretched to prevent such a result. A satisfactory resolution would be to restrict Hornstein to its facts. If this were done, three atypical aspects of the case could provide parameters by which to distingnish corporate rape from corporate prostitution. First, the corporation faced the ultimate form of economic "duress," the threat of bankruptcy, if a strike occurred. Thus, the rule could be limited to situations involving a risk of an extreme loss or 
possibly a threatened injury severely disproportionate to the payment. Second, the threat was credible, as the previous year's events had amply demonstrated. Third, the payment by Paramount was not an attempt to obtain new business, which is the chief evil perceived by those most critical of contemporary corporate behavior. ${ }^{402}$ Thus confined, Hornstein might shield corporate officials in situations such as the Gulf crisis in South Korea, which threatened a $\$ 300$ million fixed investment. But it would offer no protection for corporate officials of major arms dealers like Lockheed or Northrop, who appear to have succumbed to "duress" with the quiet professionalism of a Xaviera Hollander.

An additional limitation on the duress defense, one that is particularly relevant to our special interest in the problem of information blockages, was clearly recognized by the Hornstein court. Even if the decision to submit to or resist pressure for payoffs falls within the business judgment rule, it does not follow that the judgment should be made by a subordinate corporate official, such as Keough. If the corporate superego is to function adequately, it is exactly such decisions that must be forced upwards. In Hornstein, this facet of the case did not prove fatal to the defendants because ultimately Keough's actions were ratified by the Paramount board acting with the advice of counsel. ${ }^{403}$ Such nunc pro tunc involvement of the board as the dispenser of merciful ratifications obviously is less than ideal, and more recent case law might be read to suggest that prior disclosure is required, on the theory that such policy decisions belong properly to the board. ${ }^{404} \mathrm{But}$, if the board (or an appropriate subcommittee of outside directors) could be positioned in the corporate structure so that all within

402 Suggesting that we limit Hornstein so that it does not apply to attempts to obtain "new business" forces us to define that term. At what point is the business no longer "new"? When does the expectancy that a corporation has in a profitable contract or project sufficiently ripen that the corporation is justified in protecting its interest by submitting to extortionate demands? To ignore this problem is to create an exculpatory rule capable only of protecting companies in capital intensive industries (such as the Gulf and United Brands situations) and not those in service or construction industries.

Perhaps the appropriate test to apply here is that suggested by the law of contracts: look to whether the corporation has substantially changed its position in justifiable reliance upon the contract. Such a test would ignore the usual preparatory costs associated with bidding on a contract, but would recognize that an expected profit that the corporation had substantially earned was an interest in property subject to the Hornstein rationale.

40322 Misc. $2 \mathrm{~d}$ at $1006-09,37$ N.Y.S.2d at $417-19$.

404 See cases cited at note 270 supra; text accompanying notes $266-70$ supra. 
the corporate hierarchy perceived it, and it alone, as the only source of legal immunity for corporate officials who find themselves caught in such delicate situations, then a relatively powerful positive incentive would exist for information flow to the board.

As a final observation, it cannot be ignored that Hornstein stands alone as a precedent. It remains uncertain whether courts in other jurisdictions, influenced by our current post-Watergate morality, would follow the case today. Nevertheless, Hornstein's root idea has deep support in the law. The defense of "justification" is recognized by the Model Penal Code, ${ }^{405}$ and the concept of "excusable violations" has found growing acceptance in the law of torts. ${ }^{406}$

\section{The Proximate Cause Defense and the Net Loss Rule}

Before imposing liability on a corporate official, courts have required a higher showing of causation than simply the demonstration that "but for" a given act or omission, the loss in question would not have been experienced. Instead, courts have applied the familiar proximate cause standard of tort law, requiring a sufficiently close connection between the culpable aspect of the defendant's conduct and the damage sustained by the corporation to assure that no intervening cause was more directly responsible. ${ }^{407}$

In the context of corporate misconduct, a defendant might raise this issue of proximate causation in any of three basic fact patterns. ${ }^{408}$ First, where the defendant's liability is to be predicated

405 Model Penal Code $\S 3.02$ (Proposed Official Draft, 1962).

406 See text accompanying notes 241-45 supra.

407 For an excellent description of the shifting trends in the case law on this issue, see Dyson, The Director's Liability for Negligence, 40 IND. L.J. 341, 358-67 (1965). Cases in which the defense of lack of causation has exempted directors include Hoehn v. Crews, 144 F.2d 665 (10th Cir.), aff'd, 324 U.S. 200 (1944); Barnes v. Andrews, 298 F. 614 (S.D.N.Y. 1924) (L. Hand, J.); Wallach v. Billings, 277 Ill. 218, 115 N.E. 382 (1917); Allied Freightways v. Cholfin, 325 Mass. 630, 91 N.E.2d 765 (Mass. 1950).

408 It must be noted that the proximate cause defense seems to have lost much of its earlier potency, possibly reflecting shifting public attitudes toward corporations and increased concern about corporate misconduct. Some modern cases appear to conclude that all that must be shown is that the directors "abdicated" their responsibilities. See, e.g., Neese v. Brown, 218 Tenn. 686, 405 S.W.2d 577 (1964). In DePinto v. Provident Security Life Ins. Co., 374 F.2d 37 (9th Cir. 1967), the defendant raised the proximate cause defense, arguing that even if he had made a prudent investigation, he would have discovered nothing suspicious. 374 F.2d at 43 . The court artfully evaded this argument, without discrediting the idea that proximate causation must exist.

However, the proximate cause doctrine does remain alive to an uncertain degree. See Bellis v. Thal, 373 F. Supp. 120, 133 (E.D. Pa. 1974), aff'd without published opinion, 510 
upon an omission, such as inadequate supervision of a subordinate, the issue arises of whether the loss would have been averted even if reasonable diligence had been exercised. Where a reasonably prudent supervisor would still not have detected the misconduct, the negligence of a less careful one might be said to have been causally irrelevant. Second, where the loss is attributable to a supervening cause, the question becomes whether that intervening cause was reasonably foreseeable. For example, disclosures of foreign bribes occasionally have resulted in the nationalization of the bribing corporation's assets in the host country. Depending upon the given facts, such a sequence of events might be characterized alternatively either as a predictable response to conceded illegality (i.e., "the wages of sin") or as the intervention of an independent cause (the desire of a militant faction in the host country to seize upon the disclosures as a pretext for nationalization). ${ }^{409}$ The third situation raising the proximate cause issue is where the payment is "defensive," and arguably represents the less severe of two adverse alternatives. In this situation, a loss already was inevitable, and the corporate official's actions only mitigated a greater one. Finding a lack of proximate cause in this situation might supplement the duress defense (particularly in situations involving clearly illegal payments, where Hornstein would be inapplicable).

Few cases have considered the proximate cause issue in this third situation, where the defendant in effect has faced a Hobson's choice. An exception is Michelsen v. Penney. ${ }^{410}$ There, Judge Augustus Hand argued in dissent that directors of a failed national bank should not be liable for losses on loans made in violation of certain statutory reserve requirements, because the alternative they faced, to cease making loans altogether and thereby force the bank into "early liquidation," was worse. ${ }^{411}$ As long as the loans

F.2d 969 (3d Cir. 1975); Lawson v. Baltimore Paint \& Chem. Corp., 347 F. Supp. 967, 984 (D. Md. 1972) (in both cases, negligent directors held not liable for reduction in value of certain assets in absence of proof that they "caused any such decline"); W. FLetcher, supra note $246, \S 1087.1$; H. HENN, supra note 246 , $\$ 234$, at 456 .

409 Tracy states that the United Brands bribery disclosures gave Honduran politicians an "irresistible opportunity to extract valuable concessions from United Brands." Tracy, supra note 2, at 147 . However, it certainly also is arguable that such reactions by now are sufficiently foreseeable to be within the scope of proximate causation.

410135 F.2d 409 (2d Cir. 1943).

411 Id. at 436. Judge Hand agreed that " 'but for' the violation of the statute the loans would not have been made" nor the loss incurred. But he argued that the impairment of the bank's reserves, which made the loans unlawful, was not sufficiently causally 
were prudent, he contended, the directors merely were making the best of a bad situation. Yet, writing for a divided majority, Judge Charles Clark found sufficient proximity between the violation and the loss to impose liability. ${ }^{412}$ Elsewhere in that decision, however, Judges Hand and Clark joined (over Judge Jerome Frank's strong dissent) to absolve from liability defendants who had participated in a scheme to place statutorily ineligible directors in office, because they could not see any "causal connection between the act interdicted and the loss." ${ }^{413}$ They sought to distinguish this statutory violation from the other by the fact that the "illegal" directors had not been "irresponsible." ${ }^{414}$ However, this appears equally true for the "illegal," yet financially sound, loans. The only reasonable distinction to justify the differing legal consequences flowing from these two violations is the degree of remoteness of the harm from the defendants' actions. ${ }^{415}$ In short, the majority opinion rejects both the argument that the defendants' illegal actions avoided a greater loss and the counter-argument that, having acted illegally with at least a reckless disregard for the law, they should be held liable for all losses thereby caused in fact. Instead, Michelsen shows a sophisticated court turning (albeit on a highly divided basis) to proximate causation as a mediating doctrine, both to preserve the flexibility to reach desired results and probably to respond to unarticulated equitable considerations.

Closely related to the issue of causation is the question of whether there has been any loss at all. Michelsen adamantly placed on the plaintiffs the burden of proving the loss flowing from the violation. ${ }^{416}$ Some New York cases have gone further, requiring plaintiffs to prove that the damage from the illegal activity was not

related to the loss. The majority's position, he concluded, unwisely gave directors of the troubled bank the impossible choice of either becoming guarantors of the loans they unlawfully make or liquidating the bank, a step which the bank regulators had deliberately refrained from taking. $I d$.

412 Id. at 419 (citing Restatement of Torts $\$ 286$ and noting that the violated statute was "for the benefit" of the creditors bringing the suit).

413 Id.

414 Id.

115 Although both making the loans and appointing the ineligible directors were unlawful, the proximity between the unlawful act and the loss does seem considerably closer in the case of the loans. The court also refused to find certain other illegal borrowings to have caused losses. Id. at 427 .

116 Id. 
outweighed by any profits that also resulted. ${ }^{417}$ In the most recent and expansive of these cases, the court dismissed a derivative action against officers of Olin Mathieson Chemical Corporation, reasoning:

The serious weakness in plaintiff's complaint, whatever the relief sought may be, lies in the fact that damage in a situation such as is presented in this complaint may not be presumed from the mere imposition of a fine, the expenditure of specified substantial sums of money in defending criminal contempt proceedings or the exposure to anti-trust suits on the part of customers, in the absence of allegations in the complaint excluding the possibility that "Olin" may have gained more from the price-fixing conspiracy than the amounts of the fine paid and the expenditures said to have been incurred or risked. ${ }^{418}$

It is, of course, possible to criticize this "net loss" rule on a number of grounds. ${ }^{419}$ Most vulnerable to attack is its allocation to the plaintiff of the burden of proving that a known loss was not offset by possible past profits. That allocation fails to recognize that the defendants, given their control over the corporation, are relatively

417 See Smiles v. Elfred, N.Y.L.J., Feb. 20, 1963, at 14, col. 6 (Sup. Ct.) (discussed at note 418 infra and accompanying text); Borden v. Cohen, 231 N.Y.S.2d 902 (1962) (dismissing complaint alleging $\$ 50,000$ fine after plea of nolo contendere and threat of treble damage actions for antitrust violations); Spinella v. Heights Ice Corp., 186 Misc. 996, 62 N.Y.S.2d 263 (1946); cf. Hoffman v. Abbott, 180 Misc. 590, 594-96, 40 N.Y.S.2d 521, 525-27 (1943); Diamond v. Davis, 263 App. Div. 68, 69, 31 N.Y.S.2d 582, 584 (1941) (specific wrongful acts and resulting losses must be alleged). In each of these cases, the court ruled that no damage to the corporation is to be inferred from antitrust violations. Because the treble damage provisions of the antitrust laws make the costs of an antitrust violation more likely to outweigh its benefits than other kinds of statutory violations, the rule of these cases would seem to apply a fortiori to illegal payments situations, where the sanctions are less.

An analogous "out of pocket" damage rule seems to have evolved under the federal securities laws. See Richardson v. MacArthur, 451 F.2d 35 (10th Cir. 1971); Herpich v. Wallace, 430 F.2d 792, 810 (5th Gir. 1970); Abrahamson v. Fleschner, 392 F. Supp. 741, 746-47 (S.D.N.Y. 1975) (profits offsetting losses).

418 Smiles v. Elfred, N.Y.L.J., Feb. 20, 1963, at 14, col. 6 (Sup. Ct.) (emphasis in original). To the extent that the court would also deny prospective injunctive relief pursuant to the emphasized Janguage, this case seems to represent a minority position. See W. Fletcher, supra note 246, § 5823; note 261 supra.

419 For the best discussion of problems in this area, see 64 Colum. L. Rev. 174 (1964). One New York case has taken a contrary position, but did not discuss its apparent rejection of the "net loss" rule. See Premselaar v. Chenery, Civil No. 6151 (N.Y. Sup. Ct., N.Y. County, Feb. 13, 1963). See also Forte, supra note 271, at 336-39 (approving the "commendable restraint" of courts following this net loss rule). 
better situated to prove the economic consequences of their conduct. Also, considerations of fairness favor placing the burden on the defendants, because they both have the resources available to offer any relevant evidence and, as lawbreakers, are not unjustly prejudiced by having to raise the issue as an affirmative defense. ${ }^{420}$ In response, the defendant can argue that allocating the burden of proving a net loss to the plaintiff may conform with the practice of assigning the burden of proof to "the party alleging the less probable alternative," 421 if most illegal corporate practices are profitable. However, this is both a formalistic rule and one inconsistent with the allocation of the burden in such related areas as transactions involving "interested" directors or the business judg. ment defense. ${ }^{422}$

But should the "net loss" rule be accepted at all? From a public policy perspective, it obviously undercuts the deterrent value of the derivative suit as a means of discouraging corporate misconduct. In addition, these New York cases-although decided by unusually able judges $-{ }^{423}$ reflect historical attitudes towards the derivative suit that now seem dated. During the period that courts clearly recognized the "net loss" rule, ${ }^{424}$ the prevailing popular perception of the derivative suit was as an action brought by a money-hungry "strike suit" lawyer, who lacked a client with a true economic interest in the outcome and who was motivated solely by a contingent fee. Since then, however, an unmistakable shift in public attitudes towards the derivative suit has taken place so that today we tend to favor the notion of "private attorneys general." 425

42064 Colum. L. Rev. 174, 178 (1964) (quoting 9 Wigmore, Evidence $\$ 2486$, at 275 (3d ed. 1940)).

421 Id. (citing Cleary, Presuming and Pleading: An Essay on Juristic Immaturity, 12 Stan. L. REv. 5, 12-14 (1959)).

422 Id. See also ABA-ALI Model Bus. CoRp. Acr $\$ 41$ (1971) (permitting an "interested" director to defend a self-dealing transaction by proving that it was fair).

423 For example, Justice Shientag, the author of Spinella v. Heights Ice Corp., 186 Misc. 996, 62 N.Y.S.2d 263 (Sup. Ct. 1946), also authored Litwin v. Allen, 25 N.Y.S.2d 667 (Sup. C. 1940), Casey v. Woodruff, 49 N.Y.S.2d 625 (Sup. Ct. 1944), and a number of other important corporate law decisions that cannot be characterized as overly sympathetic to management.

424 The first decision recognizing the rule, was Spinella v. Heights Ice Corp., 186 Misc. 996, 62 N.Y.S.2d 263 (Sup. Ct. 19.6). The last was Smiles v. Elfred, N.Y.L.J., Feb. 20, 1963, at 14 , col. 6 (Sup. Ct.).

425 This transition was signalled by the Supreme Court's policy-motivated relaxation of the procedural barriers to a derivative suit in Surowitz v. Hilton Hotels Corp., 383 U.S. 363 (1966). See Dykstra, The Revival of the Derivative Suit, 116 U. PA. L. Rev. 74 (1967). 
As a result, it is unclear whether courts in other jurisdictions would follow these New York cases. The Third Circuit's decision in Miller v. $A T \& T^{426}$ is symptomatic of this reversal in attitudes. The court restrictively read the New York "net loss" rule to mean only that there must be an allegation of illegal conduct resulting in "independent damage" to the corporation. ${ }^{427}$

Rejection of the "net loss" rule means civil liability is to be imposed on corporate officials for conduct that, although illegal, may actually have produced economic benefits for the corporation. Arguably, such a draconian approach, although inspired by the desire to deter misconduct, results in unjust enrichment of the corporation, which will recover from its own officials as well as receive the net benefits of the official's actions. The Supreme Court's decision in Bangor Punta Operations, Inc. $v$. Bangor \& Aroostook R.R. ${ }^{428}$ provides major support for this argument that the imposition of liability in such a context would be inequitable. In Bangor, a railroad sought to recover against its former owner for alleged acts of corporate mismanagement and violations of the federal antitrust and securities laws (statutes that are likely to be cited in any modern case involving corporate misconduct). However, the present majority shareholder of the plaintiff railroad, who was the real party in interest, had purchased its shares at a price that reflected the injury already done to the railroad. Therefore, the Court held the plaintiff to be estopped on equitable grounds from maintaining the action either on a common-law or a federal statutory theory of liability, because recovery would produce a "windfall" profit to the majority shareholder. ${ }^{429}$ Technically, the decision found the "contemporaneous ownership" requirement of rule 23.1 of the Federal Rules of Civil Procedure to bar the suit. ${ }^{430}$ But, in refusing to create an exception to reach a wrongdoer who would otherwise go unpunished, the Court enunciated several principles that directly concern us here. First, the Court stated that a loss suffered by the plaintiff is a prerequisite to a derivative suit, because any other rule would "permit the shareholders to reap a

426507 F.2d 759 (3d Cir. 1974).

$427 \mathrm{Id}$. at 763 n.5. Miller, however, does present a situation in which it is much more difficult to infer a likely benefit from illegality. This is because political contributions, unlike price fixing, only sometimes are intended to benefit the corporation financially.

428417 U.S. 703 (1974).

429 Id. at 711 .

$430 \mathrm{Id}$. at 718 n.I5. 
profit from wrongs done to others." ${ }^{431}$ It added that the need for deterrence standing alone is insufficient to justify the imposition of liability in a derivative suit. ${ }^{432}$ Finally, the Court concluded that fiduciary duties are owed "primarily to those who have a tangible interest in the corporation," ${ }^{433}$ not to the public at large, even though the public's interests are substantially affected. Although this hard-nosed attitude split the Court, winning only a bare 5-4 majority, ${ }^{434}$ it nonetheless suggests that federal courts may regard proof of a net gain to the corporation as fatal to any derivative action for damages.

In response, courts sympathetic to plaintiffs might take a broader view of the corporate injury involved. A well-known New York Court of Appeals decision, Diamond $v$. Oreamuno, ${ }^{435}$ raised the possibility of defining the injury expansively to include the stigmatization suffered by the corporation. ${ }^{436}$ Although Diamond involved not improper payments, but the quite different problem of insider trading, the court concluded that it could infer from illicit conduct an injury to the corporation's public image and goodwill. ${ }^{437}$ In the improper payments context, at least in cases where

131 Id.

432 Id. at 717. The Court relied chiefly on the equitable doctrine announced by then Judge (later Dean) Roscoe Pound in Home Fire Ins. Co. v. Barber, 67 Neb. 644, 93 N.W. 1024 (1903). In rejecting a derivative suit where the plaintiff had suffered no economic loss from the defendant's wrongdoing. Judge Pound wrote:

It is not the function of courts of equity to administer punishment. . . . If a wrongdoer deserves to be punished, it does not follow that others are to be enriched at his expense by a court of equity. A plaintiff must recover on the strength of his own case, not on the weakness of the defendant's case.

Id. at 673,93 N.W. at 1035 .

433417 U.S. at 717 n.13. Thus, according to this view, where the stockholders suffer no injury, damage to the public is apparently not actionable through a derivative suit.

431 The opinion was authored by Justice Powell. Justices Marshall, Brennan, White, and Douglas dissented.

13524 N.Y.2d 494, 248 N.E.2d 910, 301 N.Y.S.2d 78 (1969).

436 The Diamond court took a view of the derivative suit that seems contradictory to that of the Supreme Court in Bangor i Aroostook R.R. Diamond held that "the function of such an action ... is not merely to compensate the plaintiff for wrongs committed by the defendant but . . . "to prevent them, by removing . . . all inducement . . . ." Id. at 498, 248 N.E.2d at 912, 301 N.Y.S.2d at 81. Nonetheless, because Diamond dealt with recovery of a wrongful gain by insiders (i.e., an unjust enrichment situation), rather than a loss to the corporation, it did not clearly overrule the earlier New York "net Ioss" cases. In the typical situation where the "net loss" rule is relevant, no element of self-dealing is to be expected, particularly where the corporate official intends to benefit rather than injure the corporation.

137 Id. at 499, 248 N.E.2d at 912, 301 N.Y.S.2d at 82 (noting that the corporation "has 
the corporate management has been thoroughly discredited (for example, Lockheed), some such intangible injury seems obvious. For example, the corporation may have to increase expenditures for public relations, or divert valuable management time; it may lose potential contracts, or have difficulty attracting and retaining able personnel.

Two objections to this theory are foreseeable. First, the stock market prices of the corporations' securities generally have not declined significantly following disclosure of illegal payments. ${ }^{438}$ Second, the problem of measuring with any reasonable certainty the actual damages from such stigmatization is exceedingly difficult. In Diamond $v$. Oreamuno, the court could escape this problem by measuring damages under the principle of agency law that an agent must turn over to its principal any profits received from trading upon inside information. ${ }^{439}$ With improper payments, however, the question involves calculating intangible and inherently speculative losses, such as the injury to goodwill and the anticipated profits on cancelled contracts, and offsetting them against ascertainable profits from improper conduct.

Problematic as such a balancing may appear in the abstract, as a practical matter the outcome is likely to depend on which side bears the burden of proof. Therefore, a sensible resolution to this quandary would be to allocate to the defendant the burden of proving the absence of a net loss. The defendant would have to prove not only the existence of tangible benefits, but that such profits were not offset by countervailing intangible losses. If such a resolution seems too harsh, because proof of such negative facts is often impossible, a further refinement is possible. If the affirmative defense of no "net loss" fails, under traditional principles the burden of proof could shift back to the plaintiff to prove his actual damages. The court still might disregard intangible or highly speculative losses on the basis of insufficient proof. ${ }^{440}$ In short, injury to goodwill might be considered for purposes of establishing liability, but not for computing damages. The primary practical effect of

a great interest in maintaining a reputation of integrity, an image of probity, for its management and in insuring the continued public acceptance and marketability of its stock").

438 See notes 567-69 infra.

439 See Restatement (Second) of Agency $\$ 388$, Comment c (1957).

440 See 64 Colum. L. REv. 174, 176 nn.8 \& 9 (1964). 
such a shifting burden of proof might be to encourage settlements. But when a settlement does not result, such an approach would maximize the court's ability to reach a result it considers equitable on the facts. And, in many instances, the rule would result in the defendant's accountability for the exact amount of the improper payment-a result that may have some degree of equity.

The foregoing attempt to strike a compromise between Diamond and Bangor should not blind us, however, to the irreconcilable theoretical conflict between the two decisions. Diamond justifies imposing liability solely for the purpose of prevention, ${ }^{441}$ while Bangor equally emphatically rejects such a focus in favor of compensation. ${ }^{42}$ This issue of end purpose-deterrence versus compensation-has long troubled the contiguous field of tort law. Within that related field, Professor Calabresi has demonstrated that when the law seeks only to compensate accident victims, its foundation is inadequate. Prevention must be a coequal goal..$^{443}$ Therefore, Calabresi argues that wrongdoers should be "punished for wrongful acts quite apart from whether they ... compensate victims." ${ }^{444}$ Penalties should be imposed, he argues, for creating risks even when there has been no accident, ${ }^{445}$ a position that is the

441 See note 436 supra.

142 See note 432 supra. In the debate between Diamond and Bangor, much hangs on the choice of words used to characterize the position one is rebutting. While Diamond speaks of "prevention," Bangor uses the term "punishment" and thus finds it easier to announce that courts should not inflict "punishment" at the behest of uninjured stockholders in the absence of legislative instructions to do so.

443 G. Calabresi, The Cost of Accidents 37-45 (1970). This oversimplifies Professor Calabresi's terminology, which recognizes three distinct goals: (1) "primary cost avoidance" (roughly, the goal of reducing the number and severity of accidents), (2) "secondary cost avoidance" (the goal of reducing the societal costs resulting from accidents through loss spreading and insurance), and (3) the "tertiary" goal of reducing accident avoidance costs and administrative expenses. Id. at 39-67, 68-129, 224-26.

444 Id. at 302-03.

445 Id. at 306. Professor Calabresi's basic argument here (which seems equally applicable to the corporate context) is that there are not simply two parties to an accident, but broader social interests involved that require that our primary focus be on institutionalizing an effective system of deterrence. In addition, Calabresi suggests that where hazards are created and no accident results, the penalties assessed should be paid into a tort fund to compensate the predictable future victims of similar hazards. Id. While this idea is less applicable to the corporate context (where the need to compensate is less urgent and the idea of corporate officials contributing to a fund which would compensate stockholders of other corporations is less appealing), such a tort fund could be redirected and used to create goodwill for the corporation (for example, by funding its charitable contribution budget). 
functional equivalent of imposing liability in the corporate context where the corporation has not suffered a loss. Of course, one problem with applying this notion simplistically in the corporate context is that the activity deterred might not be fiduciary misconduct, but rather the high risk occupation of being a corporate director. ${ }^{446}$ Nevertheless, the arguments for giving coequal status to the goals of deterrence and compensation seem impregnable. Thus, because the Bangor decision poses a serious roadblock to the pursuit of deterrence, and because the dangers of excessive deterrence are probably more serious here than in the arena of accident law, we are reminded that the common law has a limited plasticity, and legislative balancing will be necessary to establish appropriate relative roles for the goals of compensation and deterrence. ${ }^{447}$

\section{The Business Judgment Defense: But Who Will Guard the Guardians?}

At present, two potentially contradictory principles coexist uneasily in corporate law. Each has a wealth of supporting precedent, but few cases have faced the potential conflict between them. On the one hand, it is well established that a decision by the disinterested members of the board of directors not to sue a corporate official effectively bars a derivative suit..48 In theory, courts will respect such a decision as an exercise in sound business judgment, even where the underlying cause of action appears meritorious. On the other hand, case law also supports the proposition that shareholders may not ratify an illegal or fraudulent act. ${ }^{449}$ Although

446 See note 17 supra.

447 For example, to avoid the creation of a counterproductive in terrorem effect, the most prudent course might be statutory ceilings on the maximum penalties that could be imposed in the absence of either self-dealing or a net tangible loss to the corporation. That could be coupled with restrictions on the ability of corporate officials to insure against such losses (at least where active misconduct was alleged). Such a ceiling setting approach to the question of damages has been adopted in an analogous context by the ALI's proposed Federal Securities Code, to deal with the problem of misuse of inside information. See ALI Federal Securities Code $\S 1401(\mathrm{~d})(2)$ (Revision of Tentative Drafts 1-3, 1974). This section would limit damages to the value of the securities bought or sold.

448 See Stadin v. Union Elec. Co., 309 F.2d 912 (8th Cir. 1962), cert. denied, 373 U.S. 915 (1963); Ash v. IBM, 353 F.2d 491 (3d Cir. 1965), cert. denied, 384 U.S. 927 (1966); Swanson v. Traer, 249 F.2d 854 (7th Cir. 1957); H. HEN, supra note 246, $\$ 365$, at 772; Note, The Demand and Standing Requirements in Stockholder Derivative Actions, $44 \mathrm{U}$. CHI. L. REv. 168, 193-200 (1976).

449 W. FLETChER, supra note $246, \S 724$; H. HENN, supra note $246, \S 366$, at $772-73$; 19 AM. JUR. 2D Corporations $\S 542$, at $78-79$ (1965). 
rarely discussed, a few decisions seemingly have rejected ratification even by a disinterested majority of shareholders. ${ }^{450}$ This presents a paradox: although the stockholders themselves cannot ratify illegal acts, the directors as their proxies effectively may release the perpetrators from liability by declining to sue them. At least from the standpoint of internal consistency, it seems incongruous that disinterested directors have powers denied the disinterested owners of the corporation, who appointed them. The traditional answer to this paradox is that the decision not to sue differs from a decision to ratify the underlying conduct, but at times this answer clearly elevates form over substance.

Heightening this anomaly is the fact that virtually all the recent decisions upholding the business judgment defense have come from federal courts, ${ }^{451}$ while earlier cases holding certain acts to be nonratifiable were mainly state decisions. ${ }^{452}$ Thus, nearly four decades after Erie Railroad $v$. Tompkins, ${ }^{453}$ the federal common-law doctrine surrounding the business judgment decision not to sue remains alive and well without support from any federal statute. The federal courts continue to follow pre-Erie Supreme Court decisions delineating the power of directors, ${ }^{454}$ which under Cohen $v$. Bene-

450 Rogers v. American Can Co., 305 F.2d 297 (3d Cir. 1962); Mayer v. Adams, 37 Del. Ch. 298, I4I A.2d 458 (1958); Continental Sec. Co. v. Belmont, 206 N.Y. 7, 99 N.E. 138 (1912).

451 See cases cited at note 448 supra.

452 For state cases that cast doubt on the board's power in this area, see Parish v. Maryland \&: Va. Milk Producers Ass'n, 250 Md. 24, 102-05, 242 A.2d 512, 556-57 (1968) (the directors gave certain corporate officers a general release, but the court ruled that the burden of showing that the release was fairly obtained was on the defendants); Groel v. United Elec. Co., 70 N.J. Eq. 616,61 A. 1061 (1905) (compare the result in this case with that of Gall v. Exxon Corp., 418 F. Supp. 508 (S.D.N.Y. 1976), which also dealt with a New Jersey corporation); Harris v. Pearsall, 116 Misc. 366, 190 N.Y.S. 61 (Sup. Ct. 1921), appeal dismissed, 202 App. Div. 785, 194 N.Y.S. 942 (1922) (minority stockholder may sue directors for failure to pursue a clear cause of action); Epstein v. Schenck, 35 N.Y.S.2d 969, 981 (Sup. Ct. 1939) (no right to reject a "clear cause of action"); Shaw v. Jamieson, N.Y.L.J., June 23, 1976, at 8 (N.Y. Sup. Ct.) (suggesting that the directors' decision is not conclusive, but can be substantively reviewed by the court in some circumstances), rev'd on other grounds, 55 App. Div. 2d 875, 390 N.Y.S.2d 111 (1977).

453304 U.S. 64 (1938).

454 See United Copper Sec. Co. v. Amalgamated Copper Co., 244 U.S. 261, 263-64 (1917); Corbus v. Alaska Treadwell Gold Mining Co., 187 U.S. 455, 463 (1903) ("The directors represent all the stockholders and are presumed to act honestly and acording to their best judgment for the interests of all."); Hawes v. Oakland, 104 U.S. 450 (1882). 
ficial Industrial Loan Corp. ${ }^{455}$ is now an area in which state law should govern. ${ }^{456}$

The immediate issue for our purposes, however, is whether the two doctrines can be reconciled by imposing limits on the scope of either or both of them. A good starting point is to ask a definitional question: when does a decision not to sue amount to a ratification of the underlying conduct? A partial answer is that this decision might be based on a variety of factors unrelated to the merits of the underlying conduct, such as the expense of litigation or the unlikelihood of recovery. But such an answer at times can be a cosmetic one: boards sometimes do ratify conduct by purporting to decide only not to sue. Accordingly, the important question is under what circumstances (if at all) should a court invalidate a board decision not to sue on the basis that it amounts in substance to an impermissible ratification?

An answer to this question, specially applicable to the context of corporate misconduct, once seemed to exist in the judicial counterrule that the business judgment defense did not apply when the underlying wrong involved illegality, rather than mere negligence or breach of a fiduciary duty. The source of this counterrule was Ashwander $v$. TVA. ${ }^{457}$ There a stockholder's derivative suit challenged the right of the corporation to enter into a contract with the TVA, because the TVA was allegedly "illegal" on constitutional grounds. The initial barrier for the plaintiff was whether he

455337 U.S. 541 (1948).

456 Under Cohen, a federal court hearing a diversity-based derivative suit must apply the "substantive" law of the forum state, but may apply federal "procedural" law. Id. at 555-56. After Bangor Punta Operations, Inc. v. Bangor \& A.R.R., 417 U.S. 703 (1974), there seems little doubt that questions such as the necessity of demand upon the board will be viewed as "procedural" and therefore governed by FED. R. Crv. P. 23.1. Although the power of the board to reject litigation is closely linked to the question of demand, it seems inherently "substantive." It involves the allocation of power within the corporation between the stockholders and the board, rather than the procedural issue of whether intracorporate remedies must be exhausted. Thus, the early Supreme Court cases cited in note 454 supra should be irrelevant if they conflict with the substantive decisional law of the state of incorporation. See note 464 infra.

The situation is more complex when federal jurisdiction is also based on the existence of a federal question. In such cases, some courts have refused to apply state "substantive" corporate law where it would "frustrate" a federal cause of action. See Levitt v. Johnson, 334 F.2d 815 (1st Cir. 1964), cert. denied, 379 U.S. 961 (1965); McClure v. Borne Chem. Co., 292 F.2d 824 (3d Cir.), cert. denied, 368 U.S. 939 (1961). However, to the extent state rules may potentially limit the power of the board to refuse to sue, they are likely to enhance rather than "frustrate" the shareholder's ability to pursue a federal claim.

457297 U.S. 288 (1936). 
had standing to bring the action, because the corporation's board of directors had declined to sue. The Court split evenly on this point. Writing for the Court in an opinion joined by three of his colleagues, Chief Justice Hughes concluded that the business judgment defense did not operate where the complaint alleged illegality. He wrote that if the directors were guilty of "yielding, without appropriate resistance, to governmental demands" 458 that were unlawful, then the plaintiff was entitled to protect the corporation from this "breach of duty." ${ }^{459}$ Conversely, Justice Brandeis's concurring opinion, in which Justices Cardozo, Stone, and Roberts joined, stated that the issue of illegality was irrelevant because "[s]tockholders are not guardians of the public." ${ }^{460}$ Thus, Ashwander, as a closely split pre-Erie decision, resolves little, but it does show that in the context of alleged illegality, courts will feel uneasy in accepting the business judgment defense. ${ }^{461}$

The recent decision in Gall v. Exxon Corp. ${ }^{462}$ has reopened the issue of the proper scope of the business judgment defense. In $\mathrm{Gall}$, the plaintiff sought to hold corporate officials liable for $\$ 59$ million in corporate funds that Exxon's Italian subsidiary had expended on foreign bribes and disguised political contributions. Because certain of Exxon's inside directors and senior management had varying degrees of prior knowledge of this program, the Exxon board appointed a special committee of three directors (one an Exxon employee), which determined after an intensive study and review that no action should be taken against any Exxon employee. To justify its decision, the committee cited the classic factors that

$458 I d$. at 319 .

459 This, of course, reflects a view directly contrary to Hornstein's holding that a corporation has no public duty to resist illegal demands heroically. See pages 1209-12 supra.

460297 U.S. at 343. Justice Brandeis, himself perhaps the original private attorney general, added: "Mere belief that corporate action ... is illegal gives the stockholder no greater right to interfere than is possessed by any other citizen." Id.

461 Subsequent cases have seemingly split in their interpretation of Ashwander. Klotz v. Consolidated Edison Co., 386 F. Supp. 577 (S.D.N.Y. 1974), gave a very restrictive interpretation, limiting Ashwander's applicability to situations in which the statute is itself unconstitutional, as opposed to cases of unconstitutional action by state officials under a valid statute. See also Lasker v. Burks, 404 F. Supp. 1172, 1179-80 (S.D.N.Y. 1975). Conversely, Ashwander's reasoning seems implicit in Miller v. AT\&T, 507 F.2d 759 (3d Cir. 1974). However, there the Third Circuit looked also to New York law, specifically the "public policy" doctrine. Id. at 762.

462418 F. Supp. 508 (S.D.N.Y. 1976). 
have supported business judgment defenses: "the unfavorable prospects for success of the litigation, the cost of conducting the litigation, [the] interruption of corporate business affairs and the undermining of personnel morale." ${ }^{463}$ In rebuttal, the plaintiff argued the position of Chief Justice Hughes in Ashwander.

The Gall court responded with a decision that did not consider the New Jersey law under which Exxon was incorporated, but rather assumed mistakenly that the "demand" rule of Federal Rule of Civil Procedure 23.1 subsumes the question of the extent of the board's business judgment discretion. ${ }^{464}$ It then found the Hughes position in Ashwander inapplicable chiefly on the grounds that, unlike Ashwander, the allegedly illegal conduct in Gall was no longer continuing, but had ceased four years earlier. ${ }^{465}$ Thus, because the decision not to sue was "not itself a violation of law and [did] not result in the continuation of the alleged violation of law," ${ }^{466}$ the court held Ashwander to be distinguishable and not controlling. ${ }^{467}$ The broad principle that Gall establishes is that a

463 Id. at 514 n.13.

$464 I d$. at 515 n.16. The cases cited by Judge Carter for the proposition that the demand rule is "the corollary of the business judgment rule" do not support that proposition. Both Brody v. Chemical Bank, 517 F.2d 932 (2d Cir. 1975), and In re Kauffman Mutual Fund Actions, 479 F.2d 257 (1st Cir.), cert. denied, 414 U.S. 857 (1973), are true demand cases in the procedural sense. Each involved a situation in which demand on the board was not made.

In contrast, the most important modern precedent on the business judgment defense makes clear that Erie is to be respected and state law controls. In Swanson v. Traer, 354 U.S. 114 (1957), the Supreme Court remanded a case to the Seventh Circuit with instructions to determine whether under Illinois law the action was of "that exceptional character which stockholders may bring." The Court specifically instructed the lower court that Cohen made Illinois' substantive law determinative. On remand, the Seventh Circuit answered in the negative, but expressly looked to Illinois law. See Swanson v. Traer, 249 F.2d 854, 860 (7th Cir. 1957).

At most, the "demand" requirement of rule 23.1 seems to give the board of directors a right of first refusal to take over the suit and an opportunity to interpose a business judgment defense. If that defense is interposed, its validity should depend upon state law. If the Supreme Court meant seriously its recent comments in Santa Fe Indus., Inc. v. Green, 430 U.S. 462 (1977), that it would not "federalize" state corporation law without explicit legislative support, then it would seem inconsistent to treat the business judgment defense as governed by federal standards.

465 The court also felt that Ashwander could be limited to the situation of a shareholder's derivative suit raising constitutional objections to statutory or regulatory controls on the corporation. 418 F. Supp. at 5I8.'

466 Id.

467 The court also held Miller v. AT\&T, 507 F.2d 759 (3d Cir. 1974), to be distinguishable because in that case the failure to sue was alleged to be itself illegal. $418 \mathrm{~F}$. Supp. at 518 n.19. 
business judgment by corporate directors not to sue can bar a derivative action, even when the prior conduct giving rise to the corporation's right to sue was illegal. ${ }^{468}$

How snug is this seemingly safe harbor created by Gall? For several reasons, it may be shallower and more guarded by shoals than appears at first glance. First, since Gall applies literally only when the alleged misconduct has terminated, the calculating plaintiff may be able to circumvent its rule easily by alleging that the improper activity is still continuing and, by demanding an injunction, argue that his case now fits within the Ashwander exception.

A second potential limitation on Gall emerges from its misinterpretation of rule 23.1 and its myopia regarding Erie. There may be important discrepancies between state and federal rules on the business judgment defense, thus making Erie relevant. The recent unanimous decision of the New York Court of Appeals in Barr v. Wackman $^{469}$ suggests that directorial negligence in uncovering misconduct may render the board incapable of reaching a business judgment not to sue. Although that case dealt with the issue of demand on the board (as does rule 23.1), a logical relationship exists between the business judgment defense and the long-standing rule that before a plaintiff can commence a derivative suit, he must exhaust his intracorporate remedies by demanding action by the board of directors. The major exception to this demand rule is where the court finds that the demand would have been futile because of some bias preventing the board from reaching a disinterested decision. Logically, such a finding of futility necessarily implies that on the same or similar facts the court would have to reject a business judgment decision not to sue.470

In general, recent federal cases have interpreted this futility exception restrictively, virtually holding that only specific allegations of directorial fraud or self-interest can excuse failure to make

468 Id. at 518 .

46936 N.Y.2d 371, 329 N.E.2d 180, 368 N.YS.2d 497 (1975).

470 One case, however, does suggest that a court could reject demand as futile and still accept a business judgment refusal to sue. See Nussbacher v. Continental Ill. Nat'l Bank \&: Trust Co., 518 F.2d 873 (7th Cir. 1975), cert. denied, 424 U.S. 928 (1976). That case excused demand, but refused to consider whether it would dismiss the case if such a business judgment defense were interposed. Id. at 879 . However, because the board had not formally raised the defense, and on the facts may have been unable to do so, the court's distinction seems to have been based more on considerations of ripeness than on a belief that different standards should apply to the two determinations. 
a demand on the board. ${ }^{471}$ Conversely, Barr found the futility exception applicable even though the shareholder's derivative suit did not allege fraud or self-dealing by a majority of the directors. Barr involved an unusually visible situation in which two inside directors had engaged in self-dealing, and the remainder of the board, which had stood by passively, was therefore alleged to have been negligently responsible for the resulting injury. On these facts, the court excused demand as futile because the majority directors would themselves be subject to potential liability if the suit succeeded, and accordingly could not exercise disinterested business judgment regarding the suit. ${ }^{42}$ Assuming that under the same circumstances the court would also reject a decision not to sue as tainted, ${ }^{473}$ the message here to the experienced attorney is that plaintiffs have available an easy way to circumvent the demand requirement. Simply alleging "with particularity" ${ }^{47}$ that the independent members of the board were negligent in failing to discover the breach may preclude them from asserting a disinterested business judgment not to sue the insiders. Exactly such a result is what federal courts have predicted and therefore refused to accept. ${ }^{475}$

The implications of this divergence between state and federal law are significant. Shaw $v$. Jamieson ${ }^{476}$ illustrates the likelihood of disparate results from state and federal rules. There, in a case identical to Gall, and also challenging the Exxon "Italian Connection," a New York state court followed the Barr approach and refused to accept the same business judgment not to sue to which Gall deferred. ${ }^{477}$

471 See In re Kauffman Mutual Fund Actions, 479 F.2d 257 (1st Cir.), cert. denied, 414 U.S. 857 (1973). But see id. at 269 (Coffin, C.J., concurring) (suggesting that it is unreasonable to expect that any director would authorize a suit against himself).

47236 N.Y.2d at $379-80,329$ N.E.2d at 186,368 N.Y.S.2d at 505.06.

473 Barr's test ultimately seems to hinge on the fact that the directors actually "participated" in the transaction rather than simply negligently failed to supervise errant subordinates. The court emphasized that mere "conclusory allegations of wrongdoing" would not make demands futile. $I d$. at 380, 329 N.E.2d at 186, 368 N.Y.S.2d at 506. Nonetheless, Barr seems strongly at odds with the reasoning in In re Kauffman Mutual Fund Actions, 479 F.2d at 264-65.

474 FED. R. Crv. P. 23.1 .

475 See, e.g., In re Kauffman Mutual Fund Actions, 479 F.2d at 265.

476 N.Y.L.J., June 23, 1976, at 8 (Sup. Ct.).

477 The Jamieson court declined to grant summary judgment to Exxon, finding that a trial was necessary to determine the "reasonableness" of the decision not to sue and 
Given the unsettled state of directorial discretion not to sue, it seems wiser to focus instead on the public policy implications of the rule and to ask how a court should use its discretion in this area. On the one hand, the defense can degenerate into a ritualistic incantation, by which a servile board, exercising no meaningful judgment, protects its management from lawsuits. On the other hand, the rule does respect the corporation's autonomy by permitting it to decide for itself whether it has been injured. Even more important, the rule may provide a potentially useful positive incentive by which the board can force full disclosure of information to it, since the case law is fairly clear that a release from liability given to a corporate official by a board that lacks information is ineffective. ${ }^{478}$

If we want to institutionalize a stronger corporate superego, no area of the corporate common law seems more important than that surrounding the business judgment defense. Gall notwithstanding, one has the sense that many courts would feel uncomfortable with any doctrine so prone to manipulation as the business judgment defense apparently is today. Therefore, it is important to determine how the defense's relatively nebulous standards can be tightened. Potential limitations can be grouped under two headings: procedural and substantive.

\section{a. Procedural Limitations}

Gall, Jamieson, and other decisions have recognized that the board must be disinterested to reach an effective judgment not to sue. ${ }^{479}$ But the recent federal decisions implicitly rely on the assumption that a board (or subcommittee thereof) that is not de-

the procedures by which it was reached. Id. The subsequent reversal of Jamieson by the Appellate Division was on grounds of collateral estoppel and did not question the decision on the merits. See 55 App. Div. 2d 875, 390 N.Y.S.2d 111 (1977).

478 See Burt v. Irvine Co., 237 Cal. App. 2d 828, 863-64, 47 Cal. Rptr. 392, 415 (1965); Parish v. Maryland \& Va. Milk Producers Ass'n, 250 Md. 24, 103-05, 242 A.2d 512, 556-58 (1968).

479 In Gall, the court declined to grant summary judgment for defendants in order to give the plaintiff an "opportunity" to test the "independence" of the Exxon Special Committee through "discovery, and if necessary, to request a hearing." $418 \mathrm{~F}$. Supp. at 520. But the burden of proof in this regard was placed on plaintiffs. See Lasker v. Burks, 404 F. Supp. 1172, I180 (S.D.N.Y. 1975); Bernstein v. Mediobanca Banca di Credito Finanziario -S.P.A., 69 F.R.D. 592, 598 (S.D.N.Y. 1974); cf. Findley v. Garrett, 109 Cal. App. 2d 166, $176-78,240$ P.2d 421, 427-28 (1952) (refusal of board to sue on a fraud claim is insufficient to charge fraud on information and belief). 
monstrably partisan is therefore independent. ${ }^{480}$ Once this questionable logical jump is made, the message to corporate counsel seems clear: to safeguard the board's power to thwart derivative litigation, simply make sure that the subcommittee of the board assigned to make the decision regarding the litigation has no "inside" members and has clear authority to reach an irrevocable decision. Barr, of course, supplies the counter principle that a director is not disinterested if he is a potential defendant. But, even an expansive interpretation of Barr does not eliminate one possible cosmetic solution available to defendant directors: expand the board and appoint as the litigation subcommittee new directors who, not having been in office at the time of the challenged transaction, cannot be disqualified under Barr on grounds of alleged negligence. ${ }^{481}$

In any event, extending Barr much beyond its own facts would pose serious policy problems. If we disqualify directors from deciding not to sue because they had some prior knowledge of an improper transaction and therefore arguably were negligent, we may once again significantly inhibit fuller information flow within the firm. Corporate officers would soon learn that prospective disclosure to the board would legally taint its disinterestedness and thereby undermine its ability to release them from liability. Prior involvement of the board, therefore, may be exactly the wrong basis for disqualification, because our goal is that the board prospectively review major decisions. This again presents our now familiar conflict between moralistic and pragmatic perspectives. To make the board more effective, it may be necessary to encourage the board to become involved in decisions that involve risks of illegality, not to require it to remain aloof. Such a goal requires selectivity in the sanctions we direct at the board. Again, the

480 Recent Supreme Court constitutional decisions on bias or partisanship in administrative boards seem also to take a restrictive view of what should disqualify a hearing board as partisan. See Hortonville Joint School Dist. No. 1 v. Hortonville Educ. Ass'n, 426 U.S. 482, 493 (1976) ("Mere familiarity with the facts of a case gained by an agency in the performance of its statutory role does not, however, disqualify a decisionmaker."); Withrow v. Larkin, 421 U.S. 35,47 (1975); Wolff v. McDonnell, 418 U.S. 539 (1974) (ruling that so long as prison guard was not a participant in incident he may constitutionally serve on inmate disciplinary hearing panel); Arnett v. Kennedy, 416 U.S. 134 (1974).

481 such a change in board composition has been held to make demand necessary, although demand on the original board might have been excused as futile. See Brody v. Chemical Bank, 517 F.2d 932 (2d Cir. 1975). 
counter-intuitive answer suggested by Forrester's Law appears to offer the more probable hypothesis: to make the corporation more responsible, it may be necessary to relax, not tighten, some fiduciary standards applicable to one class of corporate official-the outside director.

What procedural limitations on the business judgment defense then do make sense? I suggest we look not to the board's level of involvement, but rather to its level of "independence." Two definitions of this critical concept of "independence" are possible. It might mean only disinterestedness in the sense of not benefiting by the outcome. But a more meaningful and traditional definition of the term would be to view a board as independent only if it is "entirely autonomous, and not subject to the ... dictation of any exterior power." 482 Such a broader definition seems particularly appropriate in evaluating what is expected of a board of directors, because the board's proper role consists of more than merely being a neutral hearing body, but also subsumes the multiple tasks of an investigator, a prosecutor, and a monitoring supervisor as well.

If we condition the availability of the business judgment defense upon the existence of a board that is not merely financially unaffected by the outcome, but rather that possesses some minimally adequate capacity to investigate, supervise, and monitor management, then we have to identify the factors that give a board that capacity to hold management accountable. Within the last several years, there has developed a considerable degree of consensus over what those minimum prerequisites are. Surveying proposals to make the board more effective, one recent study identified the basic tenets of this new consensus as follows: (l) "outsiders" must constitute a majority of the board, (2) they must have direct access to internal information about the corporation through such devices as an audit committee or a staff system, and (3) they must control the proxy process by which the corporation nominates candidates for election to the board. ${ }^{483}$ While the first two of these criteria would have been wildly heretical only a decade ago, today both are commonplace. A 1976 survey of 646 public corporations, conducted by the management consulting firm of Heidrick and Struggles,

482 BLack's LaW Dictionary 911 (rev. 4th ed. 1968).

483 J. Bacon \& J. Brown, Corporate Directorship Practices: Role, Selection and Legal STATUS OF THE BOARD 5 (1975). 
found that "outside" directors composed the majority of the board in over two-thirds of the corporations studied. ${ }^{484}$ In addition, $93 \%$ of the same companies utilized an audit committee. ${ }^{485}$ More importantly, the mandatory institutionalization of these reforms for public corporations already seems to be close to realization. As noted earlier, the New York Stock Exchange will soon require "audit" committees. ${ }^{486}$ And, since 1976, the SEC has begun to urge the stock exchanges to consider requiring listed corporations to have majority "outside" boards. ${ }^{487}$

As for the third criterion, although it has begun to gain notable adherents among academics, ${ }^{488}$ practitioners, ${ }^{489}$ and members of Congress, ${ }^{490}$ the idea that the outside members of the board should control the proxy machinery for purposes of nominating successor directors is both further from general acceptance and more critical in its impact. The basic goal of the reform would be to alleviate the much-observed phenomenon of outside directors feeling a sense

484 The Changing Board, supra note 384 , at 6 .

485 Id. at 10 .

486 See note 322 supra.

487 See id.

488 See Leech \& Mundheim, The Outside Director of the Publicly Held Corporation, 31 Bus. LAw. 1799, 1830-31 (1976). Professor Eisenberg would go further and give a greater role to the shareholders themselves. See M. Eisenberg, supra note 12, at 97-127. From the standpoint of this article, such a dependence on shareholder initiative seems unrealistic, and may be counterproductive to the extent that it might retard the process by which an "outside" director majority could obtain the balance of power on the board. In this process, delegating the nomination of new directors to a committee of outsiders is the key catalyst, and that would be lost if we instead were to depend on a complex shareholder nominating procedure. Such a shareholder procedure is, however, under consideration. See SEC Exchange Act Release No. 13482, [1977 Current Binder] FEd. SEc. L. REP. (CCH) I 81,130 (April 28, 1977).

489 See ABA Subcomm. on Functions and Responsibilities of Directors, Committee on Corporate Laws, Corporate Director's Guidebook, 32 Bus. LAw. 5, 35-36 (1976). Not surprisingly, this report takes a somewhat weaker position, suggesting that the nominating committee of outsiders only recommends nominations to the board, where presumably the chief executive officer could seek to have their nominations blocked. The report also recommends close "consultation" between the chief executive and the committee. Id. In what may be a rear-guard action, however, even these proposals have been attacked by the ABA Committee on Corporate Law Departments (a committee composed of inside or "house" counsel). See ABA Comm. on Corporate Law Departments, Report on Corporate Director's Guidebook, 32 Bus. LAw. 1841 (1977).

490 The Subcommittee on Oversight and Investigations of the House Committee on Interstate Foreign Commerce has endorsed the idea of an independent nominating committee for public corporations. See FEDERAL Regulation and REgUlatory Reform, supra note 2, at 35 . 
of reciprocal loyalty to the chief executive officer who appointed them. ${ }^{491}$ But, the impact would be greater. A legal strategy that forces management to cede control over the nomination process to the outside members of the board might as a by-product also reduce the tendency towards "group think," which organizational theorists regard as perhaps the greatest barrier to improved decisionmaking within organizations. ${ }^{492}$

The significance of management's control over the selection of even outside directors comes into clearer focus when we note that the Heidrick and Struggles survey found the chief executive officer to be the "initial decision-maker regarding a prospective director" in $46.5 \%$ of the companies studied. ${ }^{493}$ Even this figure does not reveal the full extent of the chief executive's veto power over the selection of any potentially independent new director. Still, the most striking finding of the Heidrick and Struggles study is the evidence of a trend: the chief executive's role is actually growing in the selection of outside directors. ${ }^{494}$ It seems reasonable to infer that this increased role of the chief executive relates closely to the opposing trend toward majority "outsider" boards. As the composition of corporate boards has shifted toward "outside" directors, chief executive officers increasingly have begun to "hand pick" the outsiders who hold the balance of power. Although a chief executive has other reasons to select directors personally than simply a desire to surround himself with loyalists, it is likely that he also recognizes that the shift toward an "outsider" board would eventually reach a "critical mass" level in terms of the directors" group consciousness-a development that he can attempt to forestall by seeking to frame their group identity in terms of their relationship to him. In any event, these two diametrically opposed

491 For a good summary of this argument, see M. EIsEnberg, supra note 12, at 146-47 (collecting the evidence on the degree to which even outside directors are hired and fired by the chief executive officer).

492 Janis and Mann argue that the dangers of "group think" are greatest in "highly cohesive" and homogeneous groups. 1. JANIS \& L. MANN, supra note 29, at 129-33. The answer that they propose is a "multiple advocacy" system, which seems to require the systematic introduction of outside, heterogeneous viewpoints-a pattern less likely to be achieved where the chief executive appoints and fires the board. Id. at 397-400.

493 The Changing Board, supra note 384 , at 8 .

194 Compare id. (chief executive officer initial decisionmaker in $46.5 \%$ of companies) with Corporate Boards Have Gotten Smaller Over Past 5 Years, Survey of Firms Finds, Wall St. J., Jan. 19, 1977, at 6, col. 2 (discussing earlier Heidrick \& Struggles survey that found the CEO dominant in only $14 \%$ of companies in 1971 survey). 
trends may well offset each other in their net effect on the "independence" level of the typical board.

An equally ominous finding in the Heidrick and Struggles survey is that chief executive officers frequently are able to demand the resignations of directors who resist their policies. Approximately one-third of the corporations responding in the survey reported such involuntary removals of directors. ${ }^{495}$ Abraham Pomerantz, the noted plaintiff's attorney, once told a congressional committee that the problem with the idea of a "watchdog board" was that the watchdog was chosen by the man he was supposed to watch. ${ }^{496}$ What he neglected to add, as this statistic shows, is that the watchdog who bites is quickly sent to the pound. In conclusion, if "group think" is a leading cause of the often poor quality of decisionmaking within organizations, then reduction of the chief executive's power over the composition of the board may be a wise reform. The centrality of his role in both hiring and firing directors may be responsible for the shared and often incestuously narrow perceptions of reality within the board, which is at the heart of the "group think" problem. In corporate decisionmaking, as in genetics, cross-breeding can produce a stronger hybrid.

There are of course many routes by which to force increased independence of the board, including legislation, stock exchange rules, and increased disclosure. But the possibility of a judicial initiative has received little attention. The judicial approach would be far less intrusive upon the corporation's autonomy, because courts would not have to mandate such a reform. Instead, they simply could create a positive incentive to induce management voluntarily to surrender control of the proxy machinery to a nominating committee of "outside" directors. Exactly the opportunity to create such an incentive is presented by the Gall-type problem: by conditioning the availability of this defense upon the existence of a board that was not selected by those whom it is charged with watching, courts could promote the institution of a truly "independent" board, an important corporate reform. Companies would be free not to adopt such a reform, but it would be precisely those

495 The Changing Board, supra note 384, at 11 .

496 Mutual Fund Legislation of 1967: Hearings on S. 1659 Before the Senate Comm. on Banking and Currency, 90th Cong., 1st Sess. 691 (1967). 
companies that deserve close judicial scrutiny when they assert the business judgment defense.

How realistic is it to expect courts to pursue this or any other policy-oriented strategy in the context of shareholders derivative litigation? At present, few signs at the federal court level are encouraging. Rather, the trend seems to be toward a hollow, formalistic definition of "independence." Lasker $v$. Burks, ${ }^{497}$ another mutual fund derivative suit, is a depressing case in point. There the plaintiffs contended that the court should disregard the board's decision not to sue the fund's investment adviser, because the allegedly disinterested directors were also directors of other funds established and serviced by the same investment adviser. ${ }^{498}$ Thus, suing the investment adviser might cost them their positions as the "independent" minority directors of the other mutual funds. Initially, the court gave the plaintiffs a designated period to prove their contention that these directors were not disinterested. ${ }^{499} \mathrm{But}$ later, the court held that a showing of such a structurally inbred relationship was insufficient proof, and that only a demonstration of "improper motive" would suffice. ${ }^{500}$ In addition, it rejected the plaintiffs' attempts to place the burden of showing the board's independence on the defendants. ${ }^{501}$ By placing the burden squarely on plaintiffs, Lasker gives decisive effect to the kind of evidence that is most subject to formalistic manipulation: evidence that the allegedly partisan directors met with independent counsel, considered counsel's views in detail, and studied the matter in depth before deciding not to sue..$^{502}$

497426 F. Supp. 844 (S.D.N.Y. 1977). After this article went to press, the Second Circuit reversed Lasker on grounds unique to the investment company context. See No. 77-7060 (2d Cir., filed Jan. 11, 1978).

$498426 \mathrm{~F}$. Supp. at 850 .

$499 \mathrm{Id}$. at 847 .

500 Id. at 849 .

501 Id..at 852-53. Plaintiffs of course cited Perlman v. Feldmann, 219 F.2d 173, 178 (2d Cir.), cert. denied, 349 U.S. 952 (1955), and Pepper v. Litton, 308 U.S. 295, 306 (1939). Defendants relied on Bellis v. Thal, 373 F. Supp. 120, 124 (E.D. Pa. 1974), aff'd, 510 F.2d 969 (3d Cir. 1975); Marco v. Bank of New York, 272 F. Supp. 636, 639 (S.D.N.Y. 1967), aff'd, 398 F.2d 628 (2d Cir. 1968); and Warshaw v. Calhoun, 43 Del. Ch. 148, 22I A.2d 487 (1966). The court distinguished Perlman and Pepper as cases involving self-dealing by fiduciaries and saw the procedural setting not as an affirmative defense raised by defendants, but as involving the issue of plaintiffs' standing.

502 Clearly, the court was impressed by the special committee's use of the former Chief Judge of the New York State Court of Appeals as their special counsel. Judge Fuld's role in Lasker was later paralleled by a similar appearance of retired New Jersey Chief Judge Joseph Weintraub in Gall v. Exxon Corp., 418 F. Supp. 508 (S.D.N.Y. 1976). This 
In contrast to this judicial deference, the SEC recently used evidence of a corporation's halfhearted investigation of its insiders as proof of securities law violations. In a 1977 consent order, Zale Corporation agreed to restructure its audit committee, provide adequate training for its new directors, and expand the number of independent outsiders on its board, largely because of evidence that the board had engaged in an investigation of certain alleged illegal activities by management that amounted to a coverup. At issue in the Zale case were allegations by a former treasurer of the corporation that the company had systematically violated United States and foreign tax laws, and had split the spoils between the corporation and management. ${ }^{504}$ To evaluate these charges, which centered on the corporation's chairman, the Zale board relied on an investigation conducted principally by the chairman's son. Although the "independent" committee charged with conducting the investigation was composed of outsiders, as in Lasker, the SEC concluded that it had failed to "conduct a meaningful independent investigation." ${ }^{505}$ When increasing pressure led the committee to attempt a fuller investigation, the full board interfered and eventually abolished the committee.506 Although the Zale situation involves more outrageous conduct than Lasker, the point is that decisions such as Lasker and Gall may encourage such attempts at token compliance, because they show little judicial interest in piercing the veil of formalism to achieve a meaningful definition of board "independence." The vacuum these decisions create then invites SEC activism to fill the void, resulting in an overexpansion of that agency's jurisdiction that may well be undesirable. ${ }^{507}$

suggests that, if nothing else, recent developments will provide full employment for retired appellate judges. Plaintiffs unsuccessfully sought to point out in Lasker that, although Judge Fuld had delivered a formal opinion advising the special committee as to their options, the actual counsel present at meetings of the committee were two attorneys who would not have qualified as "non-interested" persons under section 2 of the Investment Company Act. 426 F. Supp. at 849-52. The court, however, distinguished Papilsky on the basis that the law firm in question represented only the fund and not the investment adviser.

503 SEC v. Zale Corp., SEC Litigation Release No. 8081 (N.D. Texas Civil Action No. CA 3-77-1119c, Aug. 24, 1977).

504 Zale Consents to SEC Order Requiring 3 New Directors, Revamped Audit Panel, Wall St. J., Aug. 22, 1977, at 8, col. 1.

505 SEC Litigation Release, supra note 503, at 2.

506 Wall St. J., supra note 504.

607 See Part III infra. 


\section{b. Substantive Limitations}

Procedural reform has its inevitable limitations; no matter what procedural reforms are instituted, the possibility of a passive board will remain for at least the immediate future. The issue, therefore, is whether a court can ever distinguish between a "valid" business judgment and a purported judgment that amounts in reality to a ratification of a "nonratifiable" wrong. For practical purposes, this issue translates into the question of what standard of judicial review a court should employ in scrutinizing the reasons given for a decision not to sue. Several commentators have suggested that the common-law rule that some acts are nonratifiable justifies a limited degree of judicial review. ${ }^{508}$ But how would such a system work?

In overview, there are several potential bases on which a court could reject the justifications given for such a decision. First, the reasons given might appear patently spurious. For example, the justification that the law was too uncertain would hardly suffice in a case of simple price fixing. Second, the reasons might appear to amount to a continuing authorization of palpably illegal action. Presumably, no court today would accept the justification that illegal domestic political contributions promoted the corporation's longrun best interests. Third, the reasons given might lack particularity, seem unfocused, or involve a defective chain of reasoning. For example, one reason given in Gall was that any litigation against employees would hurt employee morale. Unless carefully limited, such a reason proves too much, because it could justify overlooking virtually any offense. ${ }^{509}$ Presumably no board would phrase its justifications quite as clumsily as the foregoing examples suggest; still, their statements may contain unexplained discrepancies or ambiguities, and frequently may raise further questions. ${ }^{510}$

508 See Note, The Nonratification Rule and the Demand Requirement: The Case for Limited Judicial Review, 63 Colum. L. Rev. 1086, 1103-04 (1963); Note, Demand on Directors and Shareholders as a Prerequisite to a Derivative Suit, 73 HARv. L. REv. 746, 759-62, 762 (1960) ("In theory, at least, ratification of the wrong and disapproval of the suit are not the same, but in practice the two are . . closely related . . . .").

509 For a summary of reasons that courts have accepted in upholding directors' disapproval of suits, see S. Solomont \& Sons Trust, Inc. v. New England Theatres Operating Corp., 326 Mass. 99, 108-09, 93 N.E.2d 241, 246 (1950); 35 MinN. L. Rev. 401, 403 (1951). See also note 463 supra.

510 The reports submitted by corporations in connection with the Voluntary Disclosure 
Does this mean that a court should reject the validity of a decision not to sue only in egregious cases, otherwise abstaining from interference in internal corporate affairs? While this may happen, the judicial responsibility in this area should be broader. Beyond looking simply at the persuasiveness of the reasons given, the court should consider context as well. For example, a board disapproval of a derivative action against unrelated third parties should require less justification than a refusal to sue corporate insiders. Beyond this simple level, the symptom that should most arouse judicial concern would be when the underlying conduct suggests that the corporation's own system of internal accountability has broken down. For example, in Gall, Exxon's senior management, including its chief executive officer, knew of Exxon's Italian Connection, but never disclosed it to the board. ${ }^{511}$ Such a fact pattern is decidedly different from the garden variety allegation that a corporate official has been negligent or disloyal. If the first principle of corporate law is that the board of directors shall manage the corporation, then, because nondisclosure undercuts the board's ability to monitor, a court should recognize an obligation to assure itself that the basic system of corporate accountability imposed by the state-supervision by the board-has been reinstated and is functioning. Therefore, a court should only accept a decision not to sue corporate insiders in such a case after it has determined that the

\footnotetext{
Program bear this out. The Exxon Report presents a good example. Written in a far more argumentative, self-justifying tone than the McCloy Report, it places virtually the entire blame on one subordinate official, the president of Esso Italiana, despite varying degrees of prior knowledge on the part of his superiors in the corporate hierarchy. Particularly disturbing is the report's failure to address the published statements of Exxon's former general auditor that:

The principal factor which permitted the irregularities to occur and remain undiscovered for such a long time was the fact that higher levels of management in both the region (Esso Europe in London) and Jersey (Exxon in New York) condoned the falsification of records to obtain funds for confidential special payments.

Fiasco in Italy: Political Slush Fund Hid Other Spending, Cost Exxon Millions, Wall St. J., Nov. 14, 1975, at 1, col. 6, 24, col. 3 (quoting H. Schersten). It is exactly this kind of remaining ambiguity that a court might be expected to resolve before accepting the business judgment disapproval of a suit.

511418 F. Supp. at 512. In addition, the Exxon Report reveals classic information blockages. Information was hidden from internal auditors, and the gencral counsel and controller agreed to withhold information from the chief executive because "detailed knowledge could be embarrassing to the Chief "Executive at some occasion on the witness stand." Exxon REPORT, supra note 2, at 26. The president of Exxon's European subsidiary became aware of some of the most questionable payments before they were made and did not alert higher authorities. Id. at 33-34.
} 
ability of the board to monitor has been restored. Put simply, the board's watchdog role is not optional. Just as it would be beyond the board's power to abolish itself, so too it cannot relinquish its obligation to "manage the corporation" (at least in the sense of maintaining some degree of internal supervision). Supervision is a duty imposed by the state, which neither the board nor a court can permit to be usurped. ${ }^{512}$

The appropriate interaction between court and board in this area seems best modelled after the kind of dialogue that frequently arises in the judicial review of administrative action. ${ }^{513}$ In reviewing decisions by those bodies, courts do not substitute their own determinations even when confronted by a justification from the agency that clearly is inadequate. Rather, the court will remand for reconsideration, thereby prodding the agency to articulate its decision more fully, to consider other possibilities or simply to utilize the greater expertise it presumptively possesses. Similarly, it seems equally inappropriate for a court to substitute its own judgment when considering whether a corporation should institute a lawsuit. That determination is better left to the expertise of a properly functioning board, which is more familiar with the needs and goals of the corporation.

Additionally, by simply overturning a board's decision not to sue, a court would do little to create a more effective board. In contrast, the opening of a dialogue of questions and answers between court and board may crystallize a greater sense of self-awareness on the part of the board, particularly if its outside majority theretofore had been passive. For example, if the board's decision not to sue was based on a conclusion that the proposed lawsuit lacked merit, the court might inquire whether independent counsel had been consulted and what theories of liability were explored. If the board received a special report, and its treatment of the issues

512 Those familiar with the history of corporate law in the United States will recognize that I am here taking the side of the "concession theory" of corporate law in its neverending battle with the "contract theory." For a description of the debate, see O'Neal, Molding the Corporate Form to Particular Business Situations: Optional Charter Clauses, 10 VAND. L. Rev. 1, 20-22 (1956). While modern corporation statutes have tended to be "enabling" statutes that view the corporate charter as only a contract between the participants, the trend today may be back to a "concession" view, which sees the charter as a grant of self-governing authority from the state. See note 516 infra.

513 A classic statement of this rule of self-restraint is set forth in SEC v. Chenery Corp., 318 U.S. $80,88,94$ (1943). 
seemed incomplete, the court similarly should be responsible for seeing that any ambiguities apparent to it were clarified before it accepts the board's judgment. In this process of corporate therapeutics, the plaintiff's attorneys might also be given a role in framing questions and issues for the court (and receive adequate compensation therefor). In reality, the ultimate result of such extended hearings generally would be "bloodless"-the court would eventually accept the board's determination. But, in the process, the court effectively would strengthen the board's position vis-a-vis senior management in the internal tug of war that characterizes many corporations. If this can be done in a "bloodless" fashion, without either imposing draconian liabilities on executives or substituting judicial judgment for that of the board's, so much the better.

This analogy between an agency's decision and a board's may strike some as ignoring the fundamental distinction that agencies are public bodies and corporations private ones. But the limited degree of judicial intervention into corporate decisionmaking here advocated is justified by the ancient "concession theory" underlying corporate law. This theory rests on the premise that the state has granted the corporate charter as a privilege extended on the terms and conditions set forth in the state's corporation statute. ${ }^{514}$ If one accepts this starting point that the state has in effect delegated control over the corporation to the board as the selfregulatory body entrusted with ensuring compliance with the state's charter, then the conclusion follows logically that when this system of corporate accountability demonstrably has malfunctioned, the state has a right to demand through its courts at least a full and reasoned explanation of why the board has declined to sue those at fault. This enables the state to assure itself that the terms and conditions of its charter will thereafter be observed.

At the conclusion of Gall, Judge Carter declined to exercise any substantive review of the Exxon committee's justifications, claiming that he had no basis for asking, after the Roman poet Juvenal, "Sed quis custodiet ipsos custodes?" 515 To say that is to say that our current system of corporate accountability is purely a voluntary one, that no failsafe mechanism exists. If, however, directors 
are to a degree trustees for the state as well as for the stockholders, then the state has its own independent claim to an accounting of their stewardship..$^{516}$

\section{Summary}

The initial purpose of the reconnaissance mission now completed was to survey the degree of discretion available to a court confronted with a shareholder's derivative suit claiming that corporate officials should be held liable for misconduct engaged in to benefit the corporation. As we have seen, the spectrum of possible judicial responses ranges from imposing strict liability to recognizing defenses that, at least in combination, ${ }^{517}$ could immunize almost any form of misconduct from the reach of shareholders. Most

516 A distinction must be drawn here between a limited "concession" theory and the full-blown argument that directors are trustees who must serve the public interest. This latter position has been expounded and challenged in a classic debate in the history of corporate law. Compare Dodd, For Whom Are Corporate Managers Trustees?, 45 HARv. L. REv. 1145 (1932), with Berle, For Whom Corporate Managers Are Trustees: A Note, 45 HARv. L. REv. I365 (1932). But this more expansive argument has never been accepted by courts, and in Bangor Punta Operations, Inc. v. Bangor \& A.R.R., 417 U.S. 703 (1974) (discussed at notes 428-34 supra and accompanying text), a majority of the Court seemed to accept the proposition that directors are fiduciaries only for those possessing a "tangible interest in the corporation," not the public at large. See 417 U.S. at 716 n.13. See also Ashwander v. TVA, 297 U.S. 288, 343 (1936) (Brandeis, J., concurring: "Stockholders are not guardians of the public.").

But even if directors are not required to serve the public interest, however that term may be defined, they still might be expected to perform the specific mission delegated to them, and to be accountable to the state that assigned them that mission pursuant to the state corporation law, which has been incorporated into the corporate charter. Thus, the duty to monitor stands on a higher ground than any duty to protect the public interest. In turn, this narrower responsibility is one that courts can be expected to supervise, not simply to compensate injured stockholders, but to ensure compliance with the terms of the contract to which the state is a party. Even if the state's injury is too intangible for it to sue for damages, its courts should recognize the obligation to make certain that no continuing violation of the state-mandated system of corporate accountability is occurring before they accept a business judgment not to sue. In this light, the criticisms made carlier of the recent amendments to Model Act section 35 are again pertinent, because their tendency to reduce the duty to monitor also reduces the justification for greater judicial supervision of the substantive merits of the business judgment not to sue. See note 328 supra.

517 For example, a colorable defense of duress might support a business judgment not to sue on the grounds that the board, advised by counsel, did not consider the litigation sufficiently promising to justify the expense. The "net loss" defense similarly could be used as such a rationalization for a counsel's opinion. See Exxon REPORT, supra note 2, at 28-29, 32, for a recital of several possible defenses, including the neglected defense of proximate causation, that the Special Committee on Litigation then found justified a decision not to sue. 
likely, of course, neither extreme will prevail, and the common law's genius for deciding cases on their special facts and circumstances will function here as elsewhere.

Having examined the options open to a court, the normative question still remains. What should a court seek to accomplish by exercising its discretion in this area? Initially, three standards should guide it. First, a court should be skeptical about its ability to achieve substantive goals and aware of the limits of its institutional competence. Direct frontal approaches to the problem of corporate misconduct, such as the "public policy" doctrine, are very likely misguided. Public policy is, in the apt words of an early English jurist, "a very unruly horse, and when once you get astride it you never know where it will carry you." 518

Second, as Christopher Stone in particular has argued, the law is only one of several forces impacting upon corporate behavior, and often not the most powerful. If we attempt to change fundamentally conduct that is deeply engrained, such as the corporate norms of loyalty to superiors and secrecy vis-a-vis outsiders, simply by revising legal norms that are at best only tangentially related to the daily world of corporate executives, then either of two unintended consequences is likely. First, we may succeed only in taxing conduct that will remain prevalent. Alternatively, if we adopt more punitive sanctions, we may merely create a judicial lightning bolt which will strike down isolated trespassers, but will not create a sufficient risk, standing alone, to provide much deterrence.

However, we can attempt to channelize conduct. If we place lesser expectations upon legal norms, we many find that legal restraints that are incapable of serving as roadblocks still may perform effectively as detours-if there is an alternative course of action available to the person whose conduct we wish to influence. For example, if information blockages within the corporate structure are symptomatic of a deep-rooted instinct within all organizations to withhold adverse information, the answer. is not to enact laws to protect and encourage "whistle blowers." Rather, the law should seek to utilize other basic instincts, such as the engrained sense of obedience that characterizes most hierarchial institutions, to compel internal disclosure to the board (or mini-board). As

518 Richardson v. Mellish, 2 Bing. 229, 252, 130 Eng. Rep. 294, 303 (1824) (Burrough, J.). 
another example, the reliance on counsel defense presents a debatable issue, because it is subject to misuse. However, we hardly can eliminate the dependence of the businessman upon his private counsel; not only is it a phenomenon of American business life, but there is no practical alternative. Nevertheless, channelization is again possible. Courts can seek to regulate what counsel is relied upon, to require greater dependence on legal specialists, and to induce the employment of independent special counsel by the board.

The third standard that should guide a court requires our return to Forrester's Law and its dictum that complex social systems behave counter-intuitively. The intuitive answer to corporate misconduct appears to be that courts should enhance the role of the shareholder in the enforcement of corporate morality. This answer is questionable, because expanding the role of the shareholderplaintiff without careful consideration of the consequences may diminish the role of the board. Without some latitude, the board is likely to respond to the threat of nonfrivolous litigation by choosing the course of risk avoidance. ${ }^{519}$ Thus, if courts were to take an activist role in determining the public policy implications of corporate conduct, the result often will be boards acting not on the basis of their best judgment, but out of a fear of being sued. To promote effective and responsible boards, a balance must be struck between the countervailing tyrannies of management and of the litigious minority stockholder.

To the extent that there is an inverse relationship between the roles of the board and the minority stockholder, which should we

519 Directors do face a real risk of personal loss because their insurance or right to indemnification by the corporation may be inadequate. As noted earlier, officers' and directors' insurance policies (which many companies do not carry on their directors in any event) contain ambiguous exceptions, particularly for acts involving dishonesty. See note 17 supra. For a recent attempt by an insurer to renege on such a policy on the grounds that payment to wrongdoers was against public policy, see Flintkote v. Lloyd's Underwriters, N.Y.L.J., July 27, 1976, at 6, col. 3 (Sup. Ct.), aff'd mem., 56 App. Div. 2d 743, 391 N.Y.S.2d 1005 (1977). The extent to which liabilities under the federal securities laws may be indemnified presents a complex unresolved issue, which this article will not attempt to explore. See generally Globus v. Law Research Serv., Inc., 418 F.2d 1276 (2d Cir. 1969), cert. denied, 397 U.S. 913 (1970). However, a recent trend has been toward the cancellation of liability insurance for directors (or at least certain features of such insurance), as a basis for settling derivative actions, even over the objections of the previously insured directors. See American Employers' Ins. Co. v. King Resources Co., 556 F.2d 471 (10th Cir. 1977). 
favor? Drawing upon the work of organization theorists and economists, this article already has argued that the proper locus for reform is the board. Unlike the shareholder, who in terms of organizational distance is essentially an outsider, the board has the potential to command the corporation's auditing and internal compliance monitoring machinery. These mechanisms, according to Williamson, are much more capable than either the shareholder or the market of detecting and disciplining inappropriate behavior. ${ }^{520}$

To be sure, the board today neither commands the corporation's internal monitoring machinery nor is perceived by those within the corporate hierarchy as the ultimate authority to whom they owe allegiance, such loyalty being reserved instead for senior management. But, it is exactly these structural deficiencies-the imbalance between the board and senior management and the pervasive problem of information blockages-that courts can help to redress by intelligently manipulating legal doctrine to increase the flow of information to the board. Such increased information will augment the power of the board and, derivatively, the shareholder's power as well. This article has suggested several strategies to this end:

(1) Vigorous expansion of the principle, first enunciated in Moses v. Burgin, that subordinates must "effectively communicate" policy options appropriate for the board, or face a judicial presumption that the board would have acted differently. To date, this principle has been subject to two major limitations: a conflict of interests must exist, and federal fiduciary law must apply. This article has suggested that the first limitation is of reduced significance in the context of corporate misconduct, because unauthorized actions by corporate officials create contingent liabilities, producing inherent conflicts of interest. Further, the second limitation can be surmounted both at common law and under an implied representation theory. In addition, it is possible that the eventual adoption of stock exchange rules requiring audit committees and an "outside" majority will make the obligation to disclose to the board at least as inferable from the Securities Ex- 
change Act of 1934 as it was from the Investment Company Act of 1940 .

(2) Extension of the concept of negligence to require not simply reasonable diligence by directors, but reasonable steps to institutionalize an adequate internal monitoring system. The justification for the change would be that personal supervision of corporate affairs is now hopelessly beyond the board's effective "span of control."

(3) Conditioning the "business judgment" defense upon the existence of a truly "independent" board, whose outside members constitute a majority and possess the power to nominate their successors through the corporate proxy machinery.

(4) Restricting the "duress" defense of Hornstein to the board, in order to create a positive incentive for prospective disclosure to the board.

(5) Reallocation to the defendant of the burden of proof under the "net loss" rule.

To the extent courts have doctrinal latitude in responding to shareholders' claims of corporate misconduct, this article has argued that they should exercise that discretion less to achieve an abstract ideal body of substantive law than to induce organizational reform. By a combination of positive and negative incentives, the foregoing strategies are intended to upgrade the level within the corporate hierarchy at which sensitive decisions are made.

But, is judicial reliance on such a self-regulatory system justified by any evidence that boards will behave more responsibly than management acting on its own? This question can by no means be answered definitively, but reference to the improper payments controversy is again instructive. Relatively unnoticed among the lurid tales that have surfaced has been the seeming absence to date of involvement by outside directors. ${ }^{521}$ Indeed, the elaborate precautions taken by some chief executives to prevent the board's discovery of such programs indicates a belief that even a generally passive board might take a principled stand against misconduct. ${ }^{522}$ Such a belief appears realistic. Witness, for example, the recent experience of Eberhard Faber Inc. (the pencil company), where a board that hardly qualified as "independent" rebuffed its chief

521 See notes $92-95$ supra and accompanying text.

522 See text accompanying notes 89-100 supra. 
executive officer on just this issue. ${ }^{523}$ Faced with a proposal that Eberhard Faber acquire a minority equity position in a foreign concern that paid off local Third World officials, the board balked at even this fairly tenuous association with such payments. Ultimately, the chairman found himself outvoted by a majority that consisted in part of his college roommate, his former brother-inlaw, and even his mother. The message here is not that such an incestuous board provides a generally reliable restraint on managerial overzealousness, but that, once into the ballpark of corporate morality, directors seem more inclined to stop deferring to management and to act instead on the basis of their own standards. If one generalization about the "passionate chapter in corporate history" ${ }^{24}$ that was the improper payments controversy seems justified, it is that directors, once sensitized, tend to respond rapidly to prevailing ideas of social and moral corporate responsibility where a public consensus exists. If so, then at least with respect to those potential levers for reform that we have just surveyed, the better part of judicial valor may lie in a discretionary self-restraint, in a response that seeks less to define proper corporate conduct than to ensure that the corporation's own internal reflexes are working properly. ${ }^{525}$

\section{The Federal Securities Laws and Corporate Misconduct: Does the SEC Have a BetTer IDEa?}

A much-delayed question now surfaces: why is it necessary to strain the common law to find a remedy for corporate misconduct when the SEC appears to be directly confronting the issue? This section will explore SEC action in the corporate misconduct area as an alternative model for corporate reform.

Often hard to pin down, particularly in this area, the SEC has waivered between potentially inconsistent definitions of its role. At

\footnotetext{
523 Faber, supra note 2, at 186-88.

524 Hills, supra note 54 , at 8.

525 The questiou here is by no means whether we should rely totally on self-regulatory devices to prevent corporate misconduct. The simplest route to prevent commercial bribery is, of course, a criminal statute. The issue is rather how we should manipulate those particular levers for reform that affect the corporation's internal affairs, and whether we can accomplish anything by these levers that cannot be induced by other, more external forces for change.
} 
times, it has stood by its traditional economic definition of materiality. ${ }^{526}$ At other times, it has acknowledged that disclosure can be used as a tool to realize social goals and to protect the public interest. ${ }^{527}$ In the recent past, the Commission gave serious consideration to addressing the "control loss" problem directly, by pre-

526 By "economic" definition of materiality, I mean a standard, such as the one recently recommended by the SEC's Advisory Committee on Corporate Disclosure, which deems information relating to social and environmental affairs to be "material to investors only when it reflects significantly on future financial performance." Advisory Comm. on Corporate Disclosure, Disclosure Study Report, [1977 Current Binder] Fed. SEc. L. Rep. (CCH) If 81,300 , at 88,480 (Sept. 8, 1977). That committee concluded that even in the area of corporate sufferage decisionmaking, information was matexial only when it related to "expected return on investment." Id. Even under such a standard, there remains an issue as to when the level of "significance" is reached. While the Commission has always declined to be specific in this context, the instructions to Form $8-\mathrm{K}$ recurrently use tests of $5 \%$ and $10 \%$.

Although the Commission itself has not taken as hard a line as that recommended by its Advisory Committee, a similar attitude is discernible in its releases on environmental disclosures. See SEC Securities Act Release No. 5704, [1975-1976 Transfer Binder] FEd. SEC. L. REP. (CCH) T 80,495, at 86,292 (May 6, 1976); SEC Securities Act Release No. 5627, [1975-1976 Transfer Binder] FED. SEC. L. REP. (CCH) If 80,310, at 85,724 (Oct. 14, 1975). These releases followed the first decision by Judge Richey in Natural Resources Defense Council, Inc. v. SEC, 389 F. Supp. 689 (D.D.C. 1974). In these releases, the Commission resisted the somewhat heavy-handed efforts of that court to increase the required disclosures on "social matters" of interest to "ethical investors." The debate between that court and the Commission continues. See Natural Resources Defense Council, Inc. v. SEC, [1977 Current Binder] FED. SEc. L. REP. (CCH) $\llbracket 96,057$ (D.D.C. 1977) (discussed at note 556 infra).

527 While the SEC PAYMENTS REPORT, supra note 2, at 19-20, approaches such a position, the clearest endorsement of this deterrent function of disclosure in an official Commission report is in SEC, Disclosure ro INvestors 10 (1969) (popularly known as the Wheat Report) ("appropriate publicity tends to deter questionable practices and to elevate standards of business conduct").

Recently, several commentators have pointed to language such as that in the Wheat Report or published contemporaneously with the adoption of the Securities Act of 1933 to argue that one of the principal intended functions of disclosure has always been the deterrence of unethical behavior. See, e.g., Anderson, The Disclosure Process in Federal Securities Regulation: A Brief Review, 25 Hastnos L.J. 311 (1974); Stevenson, supra note 19. Although there is clearly some merit to this argument, one important qualification is that when the Wheat Report or the other relevant official sources have asserted that it is a function of disclosure to deter unethical behavior, they generally have implicitly meant unethical behavior by controlling stockholders directed against minority stockholders, not misconduct standing alone. A case frequently cited as an expression of judicial approval of this function of disclosure, Laurenzano v. Einbender, 264 F. Supp. 356 (E.D.N.Y. 1966), is consistent with the interpretation that only unethical behavior directed against the intended beneficiaries of the statute is within the purview of the statute. While it is possible to argue for a more generalized deterrent use of disclosure, the burden of proof should rest on those who would advance a broader theory of the deterrent intent of the federal securities laws. See note 577 infra. 
scribing federal standards for directors of public companies. ${ }^{628}$ Eventually, it quietly abandoned this project, as it came to recognize that the task was of herculean dimensions, ${ }^{529}$ and as doubts grew that the antifraud provisions of the federal securities laws could support such a substantive set of duties. ${ }^{530}$ Nonetheless, with characteristic independence, ${ }^{531}$ the SEG's Division of Enforcement has sought to address the problem of the board's impotence by obtaining consent orders that have required a variety of novel remedies. These have included the expansion and reconstitution of boards, ${ }^{532}$ the installation of a majority of independent directors,

528 The proposal to draft guidelines for the duties and responsibilities of directors was first announced by then SEC Chairman Bradford Cook. See Address by G. Bradford Cook, Southern Methodist University School of Business Administration (April 6, 1973), reprinted in [1973 Transfer Binder] FED. SEC. L. REP. (CCH) \ 79,302. A flurry of speeches by Commission members then discussed the problems of setting standards in this area. See, e.g., Address by Chairman Ray Garrett, Jr. before the Conference Board, San Francisco, Cal., A Commission Dilemma: Directors' Guidelines Revisited (May 7, 1974).

$529 \mathrm{By}$ the end of 1974, Chairman Garrett decided it was necessary to abandon the project. He announced that although the SEC expected directors "to do the right thing," it could not draft a code defining the "right thing" for complicated fact situations. In part, the Commission feared that courts miglit misinterpret a detailed code as creating ironclad rules. See Address by Chairman Ray Garrett, Jr. before Arthur D. Little Corporate Directors Conference, Washington, D.C., What the SEC Expects of Corporate Directors (Dec. 17, 1974); Chairman Hills also subsequently acknowledged the futility of the attempt. See Hills, supra note 49.

530 Santa Fe Indus., Inc. v. Green, 430 U.S. 462 (1977), seems particularly hostile to any attempt to supplant state reguiation of fiduciary duties through expansion of reIatively vague federal antifraud rules. See notes 558-60 infra and accompanying text.

531 This level of independence (or, depending on one's perspective, disregard for Commission policies) has been praised by some and criticized by others. Senator Harrison Williams, chairman of the Senate Subcommittee on Securities, recently attacked the "overbearing influence" that the Enforcement Division has had over the Commission and accused it of intruding into "regulatory and policy matters specifically delegated to others." Senator Assails Official of S.E.C. In Alleged Slurs, N.Y. Times, Aug. 8, 1977, at 37, col. 5, 39, col. 4. In this light, it is worth recalling that Professor Tullock's original research on "control loss" concluded that government agencies were particularly susceptible to the problems of "authority leakage," in part because of the ability of career civil servants to immunize themseives from the control of constantly changing political appointees. See notes 139-40 supra. Thus, given the hesitancy and divisions noted earlier among commissioners on the issue of materiality, see note 49 supra, the recent action of the staff suggests that the SEC is equally as susceptible as the large public corporation to the "control loss" phenomenon.

532 The best known and most controversial of these decisions was SEC v. Mattel, Inc., [1974-75 Transfer Binder] Fed. SEc. L. REP. (CCH) II 94,754, 94,807 (D.D.C. 1974). There the negotiated consent order required the company to name a majority of unaffiliated directors satisfactory to the SEC and to maintain executive, audit, and other committees 
the establishment of audit committees staffed by outsiders, and even orientation and minimum fee schedules for outside directors. ${ }^{533}$ In perhaps the high water mark of this campaign, the Division of Enforcement advanced the theory in one recent complaint that directors (including outside directors) who failed to control management adequately could violate the federal securities laws, because implicitly they falsely represented the material fact that they were in control of the company. ${ }^{534}$ Under such a theory, the effect of state cases such as Graham v. Allis-Chalmers Manufacturing Co. ${ }^{535}$ which permit extensive reliance on management, is overcome by the seemingly deus ex machina discovery of a federal duty of due care for directors. Apparently, directors are expected to meet some undefined federal standard of diligence in holding management accountable or make a public confession of their inability to do so. Unfortunately, such an approach seems ill-conceived from the perspective of organization theory. The imbalance between the board and management cannot be rectified so

consisting mainly or wholly of unaffiliated directors. See also Malley, supra note 41 . Similar, if less drastic, relief also has been obtained by consent order. See SEC v. Coastal States Gas Corp., Litigation Release No. 6054 (S.D. Tex., Sept. 12, 1973) ; SEC v. WestgateCalifornia Corp., Litigation Release No. 6142 (S.D. Cal., Nov. 9, 1973). Private litigation also has led to settlements in which independent directors have been appointed and the nominating process entrusted to a special committee of outside directors. The best known of these cases are those involving Phillips Petroleum and Northrop. See M. Ersenberg, supra note 12, at 175-76 n.28 (discussing Springer v. Jones, Civ. Action No. 74-1455-F (C.D. Cal. 1974) (Northrop)); Herlihy \& Levine, supra note 2, at 617-18 (discussing Celbar v. Keeler, Civ. Action No. 75-611-EAC (C.D. Colo. 1975) (Phillips)). Each settlement provided for appointment to the board of a majority of specially defined outside directors. In Springer, Professor Eisenberg served as consultant to plaintiffs and drafted the definition of "independence" used in the settlement. See M. Eisenberg, supra note 12. Detailed descriptions of recent SEC enforcement actions and consent orders are contained in the ALI-ABA Conference materials. See note 39 supra.

533 See SEC v. Zale Corp., supra note 503. That consent order established a special audit committee of the board to be empowered to investigate and press claims against management. A special corporate code of ethics, which must be submitted to the SEC, was also required, along with an orientation program and a minimum compensation schedule for outside directors.

534 See Complaint, SEC v. Shiell, Civ. Action No. TCA 76-204 (N.D. Fla. I976); SEC Litigation Release No. 7763, at 2 (Jan. 31, 1977). The corporate defendant was the Commonwealth Corporation.

53541 Del. Ch. 78, 188 A.2d 125 (1963) (discussed at text accompanying note 309 supra). See also ABA-ALI Monel Bus. Corp. Act $\$ 35$ (Supp. 1977) (discussed at notes 328-32 supra). 
easily, and some forces (as King Canute also found) may be beyond the power of a naked edict to change. ${ }^{536}$.

More recently, the Commission itself has returned to the problem of corporate governance by beginning a far-reaching inquiry into the applicability of the federal securities laws, particularly the proxy rules, as a basis for reforming the allocation of power within the corporation. ${ }^{537}$ However, the lead-off witness at the hearings that commenced that inquiry, Columbia Professor William Cary, admonished the Commission to be wary of "proliferating agency intrusion where private action suffices." "538 "A self-executing statute empowering . . . a shareholder derivative suit," he suggested, might present a more "desirable" model for reform than reliance on "direct S.E.C. involvement." ${ }^{539}$ At about the same time, the Commission released the report of its Advisory Committee on Corporate Disclosure, which strongly urged the Commission not to "use disclosure solely to regulate corporate conduct unless expressly authorized to do so by the Congress." 540 This resistance on the part of careful commentators to the SEC's expanding use of disclosure as a deterrent rests at bottom upon two concerns. First, these observers fear that reliance on disclosure may not be effective from a cost/benefit standpoint. Second, there is a foreboding sense that inflation of disclosure requirements in order to influence

536 Given the pathological situations occasionally faced in these cases, such drastic intervention and disregard for the rights of the stockholders (on whom these reforms and unelected directors were pressed without any attempt at securing their consent) may have been justified. But clearly, a remedy designed for a pathological situation should not necessarily be generalized. In particular, the Shiell theory, under which outside directors would also be liable, seems ill-considered. It seemingly requires the individual director either to engage in what frequently will be a suicidal collision with the entrenched management of many corporations, or to make a public confession of his inadequacy. 537 See SEC Exchange Act Release No. 13,901, [1977 Current Binder] FEd. SEc. L. REP. (CCH) đ 81,296 (Aug. 29, 1977); SEC Exchange Act Release No. 13,482 [1977 Current Binder] Fed. SEc. L. Rer. (CCH) If 81,130 (Apr. 28, 1977).

538 Testimony of William L. Cary before the SEC, Shareholder Communications and Participation in Corporate Governance 2 (Sept. 29, 1977) [hereinafter cited as Cary].

539 Id. Professor Cary added that with respect to his proposed federal minimum standards bill, he saw "no necessity for Commission regulation or even participation" but would rely on a "private right of action" for its enforcement. Id. at 10 .

540 See Disclosure Study Report, supra note 526, at 88,483 . The Advisory Committee further expressed the view that the Commission should be skeptical of attempts to expand disclosure requirements to comprehend more "social and environmental information" and that no additional disclosures in this area were necessary. Id. at 88,485 . 
corporate conduct may subordinate the interests of investors, who were the intended beneficiaries of those laws, to other interests. ${ }^{541}$

The issue thus framed is obviously significant. In contrast to the at best interstitial opportunities for reform through the common law, the federal securities laws appear to offer a more direct route to corporate reform. On the simplest level, disclosure does raise the corporation's "embarrassment cost," ${ }^{442}$ often to a prohibitively high level. Why then should we depend on an internal corporate superego at all, when the SEC has the potential to serve as an externalized corporate conscience? The answer given by the critics is that the deterrent effect of disclosure comes only at a price that is being wrongfully charged to investors. 'This section will examine the nature of this price, as our focus shifts to the comparative strengths and weaknesses of the two competing models for corporate reform: the private derivative suit versus a mandatory disclosure system enforced by the SEC. A particular interest during this inquiry will be to consider if, by restricting the focus of the "therapeutic disclosure" justification, we can identify certain kinds of disclosures that do not involve trade-offs between the investor's interests and those of other groups within society.

The immediate advantage of placing primary reliance upon the federal securities laws is obvious: the SEC can focus its enforcement resources directly at the substantive evils it perceives. But a further inquiry is required to decide whether the benefits of this approach outweigh its costs. In at least three respects, the SEC

541 Professor Cary in particular criticized the result in the recent Natural Resources Defense Council decision, see notes 526 supra, 556 infra, as giving insufficient attention to the "costs and benefits" of disclosure. See Cary, supra note 538, at 3. The SEC Advisory Committee similarly focused on costs and benefits and warned that "investment decisionmaking would be hampered by adding to the amount of information through which investors would have to sift in making investment decisions." Disclosure Study Report, supra note 526, at 88,477 . Both also warned about overextension of the Commission's mandate if it sought to provide information to other "interest groups in addition to investors." See id.; Cary, supra note 538.

542 While this phrase "embarrassment cost" has begun to enter the public domain, I believe it was first coined by my colleague Professor Donald Schwartz, in Schwartz, Towards New Corporate Goals: Co-existence with Society, 60 GEo. L.J. 57, 97 (1971). Recent experience with stockholder proxy proposals, particularly the unprecedented success of the American Jewish Congress in challenging the Arab boycott of Israel, suggests that their efficacy is considerable and increasing. See Talking It Over: More Concerns Willing To Enter Negotiations On Holder Resolutions, Wall St. J., March 23, 1977, at 1, 32 (noting that many public corporations have agreed to shareholder resolutions rather than be placed in the position of "being against motherhood"). 
already has given a priority to the goal of eliminating substantive evils over that of protecting investors and stockholders. First, early in the improper payments controversy, the Commission's staff departed from its conventional form of consent decree, which enjoins only further violations of the securities laws (thereby leaving unresolved the critical issue of whether the prior payments were sufficiently material to require disclosure). Instead, the staff began to negotiate uncharacteristically broad consent decrees that enjoined the "use of corporate funds for unlawful purposes." ${ }^{543}$ In some cases, these injunctions went well beyond the criminal law in prohibiting specified actions, even with disclosure. For example, one recent injunction prohibits the corporation from making any payment "in the nature of a commercial bribe" to induce business. ${ }^{544}$ Because many states and foreign nations limit their criminal proscription of bribery to governmental bribery, ${ }^{545}$ the SEC's Division of Enforcement apparently is claiming the right in such a case to make its own public policy determination of what acts should be criminalized. One could pause at length here to consider a number of questions regarding the legitimacy of administrative agencies making such legislative decisions, the use of injunctions rather than the rulemaking process to establish policy, and, most important, the absence of standards to guide the Commission. ${ }^{46}$ However, the overwhelming leverage possessed by the SEC's staff in the settlement of enforcement actions has deterred virtually all corporate defendants from challenging the chinks in the Commission's litigating armor. ${ }^{547}$

543 For a discussion of the issues raised by the breadth of these injunctions, see Lowenfels, supra note 41, at 3-7. See also Ferrara \& Brandon, supra note 39 (representative recent consent orders).

544 In SEC v. J. Ray McDermott \& Co., Civil Action No. 76-1854 (D.D.C., filed Oct. 6, 1976), the permanent injunction negotiated by the Division of Enforcement enjoined "any payment of corporate funds . .. in the nature of a commercial bribe . . . for the purpose of, or which may have the effect of, inducing the purchase or sale of goods, services or supplies."

545 See notes 84,205 supra.

546 Former Commissioner Sommer in particular has stressed the potentially lawless character of the authority claimed by the Commission if it accepts the broadest of possible justifications: that it may use disclosure simply as a tool to deter disfavored conduct without regard for its constituency's interests. As he points out, a nation concerned about recent abuses of FBI and CIA authority might well pause to consider carefully the granting of such an unlimited mandate to the SEC's enforcement attorneys. See Sommer, Therapeutic Disclosure, 4 SEC. REg. L.J. 263, 273-74 (1976).

547 Faced with an SEC enforcement action, the corporate defendant has little to gain and 
A second instance of SEC efforts to extirpate the substantive evil rather than simply to compel disclosure is evident in the administration of the Commission's Voluntary Disclosure Program. A precondition of participation in that program generally has been a "declaration of a total cessation of all questionable payments" by the board of directors. ${ }^{548}$ Why such a sweeping rejection of all forms of improper payments was thought to be in the best interests of shareholders is obscure. After all, reasonable investors may wish management to retain at least the discretion to make "defensive" or "grease" payments. Behind this moralistic stance, a shift seems discernible in the Commission's own self-image, from an agency representing a limited constituency composed of investors, to one representing the much broader constituency of the public at large. Perhaps the clearest example of this transition is the recent consent decree obtained by the Commission from Solon Automated Services, Inc.549 Under the decree, the company agreed to repay $\$ 800,000$ in improperly "skimmed" commissions. The recipients were not investors or stockholders, but rather third parties with whom the company had contracted. ${ }^{550}$ The settlement was heralded by the SEC as a precedent: the first occasion on which the SEC has required compensation for injuries sustained in business dealings with a public corporation to persons who were not in any sense securities holders of the corporation. One SEC attorney justified the consent order on the general authority of federal courts to assure that "all wrongs are righted." ${ }^{551}$ However, even accepting the highly questionable proposition that federal courts have such jurisdiction, one wonders why the SEC has any basis for seeking to right such wrongs at the expense of its traditional constituency, the investor (who ultimately would seem to bear the expense of

everything to lose through litigation, because a loss to the SEC will encourage private plaintiffs to sue and to assert the res judicata doctrine. On the other hand, a negotiated consent order does not require any admission of wrongdoing nor does it constitute evidence thereof. As of this writing, it appears that the only major United States corporation that has decided to litigate with the Commission is the Schlitz Brewing Co. (charged with illegal kickbacks to customers). See SEC Accuses Schlitz Of Making At Least \$3 Million In Illegal Payments, Wall St. J., Apr. 8, 1977, at 5, col. 2.

548 See Herlihy \& Levine, supra note 2, at 587-88, for a description of this phase of the Voluntary Disclosure Program.

549 See Solon Agrees to Pay $\$ 900,000$ That SEC Says It Owes Lessors, Wall St. J., Apr. 26,1977 , at 3 , col 5 .

550 Id.

551 Id. 
such a repayment). ${ }^{552}$ Once it is asserted that the fact of nondisclosure of the corporate misconduct in filings required to be made with the Commission or in statements otherwise subject to the securities laws justifies SEC intervention on behalf of the victim

552 Another example of this use of "deterrent disclosure" without regard to its effect on stockholders is the complaint filed by the SEC in SEC v. General Tire \& Rubber Co., [19751976 Transfer Binder] FED. SEc. L. REP. (CCH) $\Uparrow$ 95,542 (D.D.C. May 6, 1976). Although this case was ultimately settled by consent order, one fascinating portion of tbe complaint, which alleged violations of rule 10b-5 and rule 14a-9, hore the caption "Arab Boycott" and alleged as follows:

In 1970, General Tire initiated a concerted effort to get itself removed from the Arab League Boycott list. In this regard, it retained the services of Perco Establishment ("Perco"), an affiliated company of Triad Financial Establishment, which, in turn, was headed by Adnan Khashoggi. In August 1970, General Tire executed an agreement whereby in return for Perco's assistance in having General Tire ... removed from the Arab League Boycott List, General Tire paid $\$ 50,000$ to Perco at the time of the agreement, and agreed to pay an additional $\$ 100,000$ to Perco contingent on the removal of General Tire ... from the Arab League Boycott list. In 1972, such removal took place and General Tire forwarded $\$ 100,000$ to Perco.

Complaint If 49. Another paragraph of the complaint alleged that General Tire was in compliance with the Arab Boycott, but did not allege that it had committed any illegal act. Id. \ 50. In short, both paragraphs may be read as alleging that the corporation was seeking to defend itself in a manner that was less than heroic. But was it material?

It is difficult to see what theory of materiality warrants the inclusion of this paragraph in the SEC's complaint. If boycotts are a business risk that might have a material adverse effect on the corporation's earnings, they are certainly even more of a risk to noncomplying companies than they were to General Tire. General Tire's payments already had enabled it to escape the boycott's sanctions. Somehow, the Division of Enforcement seems to have determined that the described events were per se material (or perhaps the better word is "newsworthy") on the grounds that disclosure might deter others from complying. Of course, one problem with such a bootstrap theory of materiality is that the disclosure comes at the expense of the corporation's stockholders, who will indirectly suffer the sanctions for noncompliance. Relatively, it does not benefit any group of future investors, who presumably need more to be warned ahout the possible risks facing companies still endangered by the boycott. Admittedly, the issue would be different if General Tire had violated the antitrust laws, but apparently the SEC did not believe it had, because the Commission made no such complaint. In fact, because the antitrust laws may proscribe some forms of participation in boycotts, the deterrent argument for expanding the definition of materiality in this case collapses, because antitrust enforcement provides an alternative means of deterrence that is more clearly authorized.

One need not weep for the fate of General Tire to be concerned about the amorphous, subjective character of the SEC's seeming use of a "public interest" standard and its abandonment of the traditional priority to the interests of investors in favor of the pursuit of timely causes. A forthcoming article by Professor Allan Roth will provide a more extensive discussion of this case and the lack of coherence behind the SEC's position in this area. See Roth, The Arab Boycott and the Federal Securities Laws, 5 SEc. REG. L.J. 318 (1978). 
without any showing of a causal relationship between the nondisclosure and the wrong, or of the victim's status as an intended beneficiary of the securities laws, then we are in one step at the base of the proverbial slippery slope, and no meaningful distinction seems apparent between the Solon Automated Services fact pattern and any other instance of undisclosed corporate misconduct by a public corporation causing an injury somewhere to someone. In short, the implications of Solon are not only that the Enforcement Division is claiming an effectively unlimited jurisdiction over corporate misconduct, but that, in the process of seizing the high ground of moral righteousness, it seems prepared to accept casualties among its traditional wards, investors and stockholders.

A third occasion on which the SEC may have subordinated the interests of investors to the goal of substantive reform of corporate conduct may have been reached with the apparent recent termination of the Voluntary Disclosure Program. ${ }^{553}$ The end of the program also seems to imply a rejection of its compromise concept of "generic" disclosure. ${ }^{554}$ By accepting terse "generic" disclosures of the amounts and general purpose of the payments, the program succeeded in inducing significant information flow while shielding the corporation from the likely consequences of a full "confessional" disclosure of its misdeeds. A moment's reflection will show that a substantial difference exists between disclosing that "XYZ Corporation paid $\$ 3.8$ million in bribes to secure business over the past five years" and that "XYZ Corporation paid $\$ 1$ million to President $\mathrm{Y}$ of Country $\mathrm{Z}$ to secure an arms contract in 1976." In the latter case, the "embarrassment cost," and hence the deterrence, is much greater. But, the "confessional" disclosure also has a higher potential for causing fines, nationalizations, and loss of future business in country $Z$. The paradox is, of course, that by disclosing such contingent liabilities, we make dangers come true that otherwise might not have materialized; the prophecy of contingent liabilities is in a sense self-fulfilling. To its credit, the Voluntary Disclosure Program minimized this inherent conflict between the interests of the public and of the present investors by accepting the compromise of "generic" disclosure. The approach

553 See SEC Will Publicize Receipts, Namcs in Payment Cases, Wash. Post, Apr. 29, 1977, at Cl, col. 5; SEC's Program for Voluntary Disclosure of Questionable Payments May End Soon, Wall St. J., Mar. 7, 1977, at 4, col. 2.

554 Wall St. J., supra note 553. See also SEC PAYMENTs REPORT, supra note 2, at 32-34. 
gave prospective investors some notion of the corporation's contingent liabilities, without "ripening" those liabilities into actual losses or forcing the revelation of facts that, absent disclosure, posed no reasonable danger to the corporation. With the abandonment of the program, the Commission's new disclosure approach gives a perhaps unintended and probably ill-considered priority to the interests of potential investors over those of present stockholders. ${ }^{555}$

If our concern is corporate misconduct, this asserted cost to investors may not much trouble us at first. But, if the SEC's claim to regulate corporate morality is tenuous, if its arguments prove too much, then the Commission's extraordinary success in challenging corporate misconduct therefore may be a short-lived phenomenon. Moreover, the approach probably cannot be a similarly effective remedy for private litigants, upon whom we ultimately depend for successful policing of securities law violations.

Two recent Supreme Court decisions have shown the current Court to be highly skeptical of federal agencies seeking to expand their jurisdiction by resort to a "public interest" standard. $N A A C P$ v. FPC ${ }^{556}$ found that the "public interest" standard set forth in

555 Several commentators have warned against giving the interests of prospective investors an undeserved priority over those of innocent stockholders. See Mann, Watergate to Bananagate: What Lies Beyond?, 31 Bus. LAw. 1663, 1666 (1976); Note, Disclosure of Payments to Foreign Government Officials Under the Securities Acts, 89 Harv. L. Rev. $1848,1860-61$ (1976). Since today's potential investor is tomorrow's stockholder, a disclosure system which opts for warning the former of possible risks that are not otherwise ripe at the price of exposing the latter to the consequences of such publicity seems difficult to justify from the standpoint of investor protection.

556425 U.S. 662 (1976). See also Esquire, Inc. v. Walker, 151 F.2d 49 (D.C. Cir. 1945), aff'd sub. nom. Hannegan v. Esquire, Inc., 327 U.S. 146 (1946). Consistent with the reasoning in these cases, the Commission has stated that "it is generally not authorized to consider the promotion of social goals unrelated to the objectives of the federal securities laws ... SEC Securities Act Release No. 5627, supra note 526, at 85,706.

Despite the decisions in these cases one district court apparently remains unpersuaded that the Commission cannot be forced to expand its disclosure requirements to provide more information of interest to ethical investors. In Natural Resources Defense Council, Inc. v. SEC, [1977 Current Binder] FED. SEC. L. REP. (CCH) If 96,057, at 91,761-64 (D.D.C. 1977), Judge Richey has taken the position that statutory language in both the Securities Act of 1933 and the Securities Exchange Act of 1934 authorizing the Commission to promulgate rules "necessary or appropriate in the public interest" justifies requiring expanded environmental disclosures and equal opportunity statistical data, even if such information is not of interest to the reasonable investor. Judge Richey appears to have taken the position that such a "public interest" standard supplies an independent justification for disclosure, which makes irrelevant the question of whether the information 
the FPC's enabling statute did not authorize that agency to adopt rules against employment discrimination by public utilities, because such a standard had to be interpreted more narrowly in terms of the interests of the agency's special constituency, i.e., the consumers of power. The Court's tone suggests a simple, blunt message to federal agencies: "Shoemaker, stick to your last." ${ }_{557}$

The Supreme Court's decision in Santa Fe Industries, Inc. $v$. Green ${ }^{558}$ poses a far more sweeping limitation on the reach of the federal securities laws in this area. In upholding the validity of state "short form" merger statutes against the claim that the "squeeze-outs" of minority interests violated the policies of rule $10 \mathrm{~b}-5$, a sizable majority of the Court implicitly agreed that the purpose of that rule is disclosure and not the substantive regulation of corporate conduct. Going even further, six justices joined to express serious doubts that "a federal cause of action" could be implied in circumstances where " the cause of action [is] one traditionally relegated to state law ...." 559 Again, the scope of the decision is debatable, but its tone seems to radiate hostility toward any attempt to "federalize" the state law of fiduciary duties. ${ }^{560}$

was "material" at all. Id. at 91,769 n.56. Compounding the confusion, the court loosely cited NAACP v. FPC as authority for this proposition. Id.; see note 541 supra.

557 The Internal Revenue Service appears to have received a similar warning in a recent investigation of corporate slush funds. United States v. Richards, 431 F. Supp. 249 (E.D. Va. 1977), held that certain questions asked by the IRS relating to corporate slush funds were "beyond the relevant scope of an Internal Revenue Service investigation" of a corporation's tax liabilities, because they related only to the illegality of the payments and not to their deductibility. Id. at 252.

558430 U.S. 462 (1977).

559 Id. at 478 (quoting Piper v. Chris-Craft Indus., Inc., 430 U.S. I, 40 (1977)).

560 Two interpretations of this last section of the case seem possible. Read broadly, the test appears to be whether the subject matter is one that has been "traditionally relegated to state law." Read narrowly, the test is whether "established state policies of corporate regulation would be overridden." Id. at 479 . The difference between the former "overlap" test and the latter "conflict" test could be important, because few states' policies favor corporate misconduct in the same way that Delaware law clearly authorized short form mergers in Santa Fe Industries. In this light, only the broader "overlap" test would be an obstacle to SEC action, because regulation of most forms of corporate misconduct have been "traditionally relegated to state law." Arguably, however, some established state policies would "conflict" with a federal securities law approach to corporate misconduct. These include the "duress" defense, the business judgment decision not to sue, and state "security for expenses" statutes-all doctrines that are largely outflanked under a federal securities law approach. 
Cognizant that its jurisdiction is not unlimited, the SEC has responded on two quite different levels. First, it has articulated with uncharacteristic specificity various theories of materiality that attempt to explain why financially immaterial payments are of interest to reasonable investors. Second, based upon its statutory powers to require the filing of periodic reports and proxy statements, ${ }^{561}$ it has promulgated proposed rules intended to foster an improved "system of internal accounting controls." ${ }_{62}$ The potential efficacy of these approaches deserves a brief examination.

The Commission has articulated three theories of materiality to cover questionable payments. The first is that corporate involvement in these schemes is material because such acts "bear directly on the integrity of management and the adequacy of its stewardship." ${ }^{663}$ Second, to the extent that making questionable payments involves concealing secret funds or falsifying records, such practices are material because they subvert the accuracy of a company's financial statements and reveal the inadequacy of its financial controls. ${ }^{564}$ Under the third theory, improper activities reflect on the "quality of earnings" of a company and may give rise to undisclosed contingent liabilities. ${ }^{505}$ These three justifications-which may be referred to, respectively, as the "stewardship justification," the "falsification justification," and the "contingent liability justification"-have been debated at length. ${ }^{568}$ For our purposes it is only necessary to consider the general contours of that debate to reach two conclusions. First, such theories of materiality are open to a well-reasoned attack at several junctures. Second, even if valid, these theories do not provide a sufficient theoretical basis for spreading the "sunlight" of disclosure over all, or even the most common, forms of corporate misconduct.

56115 U.S.C. $\$ 78$ s (1970).

562 SEC Exchange Act Release No. 13,185, [1977 Current Binder] Fed. SEC. L. REP. (CCH) If 80,896 (Jan. 19, 1977).

563 SEC Payments Report, supra note 2, at 31. See also Herlihy \& Levine, supra note 2, at 575 .

564 SEC PAYments Report, supra note 2, at 23-24; Herlihy \& Levine, supra note 2, at 573.

565 SEC PAYMents REPORT, supra note 2, at 29-30; Herlihy \& Levine, supra note 2, at 574.

566 See sources cited notes $39 \& 41$ supra; Note, supra note 555; Note, Foreign Bribes and the Securities Acts' Disclosure Requirements, 74 Mrch. L. REv. 1222 (1976). 
The "stewardship justification" is predicated on the normative premise that stockholders care about the level of integrity of management. The empirical foundations of this premise are somewhat shaky. Polls of investors have seemed to show that there is relatively little such concern among sophisticated investors. ${ }^{567}$ Little evidence can be found that disclosure of questionable activity adversely affects the market price of a corporation's stock. ${ }^{\overline{0} 68}$ In addition, proxy proposals to restrain management discretion in this area have gone down to overwhelming defeat where management has resisted. ${ }^{\mathbf{6 0}}$ In sum, shareholders appear to show little concern about the moral peccadillos of management, or at least those adventures intended to benefit the corporation. It is certainly arguable, therefore, that only in exceptional cases do "integrity disclosures" involve information that falls within the Supreme Court's most recent and restrictive definition of materiality.${ }^{570}$

567 Only $28 \%$ of the respondents to a poll taken at the AII-ABA Securities Institute in 1975 reported that information to the effect that a corporation had made foreign payments would have a material adverse impact on their willingness to invest in that corporation. On the other hand, $62 \%$ said that a refusal by a corporation to make such payments might have a material negative effect on their willingness to invest in the corporation's securities. With a touch of cynicism, one commentator has questioned whether it is not "disclosure of the unwillingness to make" such payments that the SEC should requirc. Mann, supra note 555, at 1665. After considerable investigation of the needs of investors, the SEC's Advisory Committee on Corporate Disclosure also has expressed doubt that investor interests would be served by the inclusion of more social and economic information. See note 540 supra.

568 Note, supra note 555 , at 1855 n.45.

569 The most recent example was the lopsided rejection by Gulf shareholders of minority shareholder proposals to prohibit illegal bribery and political contributions. See Gulf Rejects Proposals to Detail Payoffs, Wash. Post, Apr. 20, 1977, at D-11, col. 1.

570 In TSC Indus., Inc. v. Northway, Inc., 426 U.S. 438 (1976), the Supreme Court rejected as the test of materiality that the fact be one that "a reasonable shareholder might consider important," id. at 446, and substituted the standard that there exist a "substantial likelihood that a reasonable shareholder would consider it important . . . " Id. at 449. More importantly for present purposes, the Court emphasized the dangers of information overload:

Some information is of such dubious significance that insistence on its disclosure may accomplish more harm than good. . . . [ I]f the standard of materiality is unnecessarily low, . . . management's fear of exposing itself to substantial liability may cause it simply to bury the shareholders in an avalanche of trivial informationa result that is hardly conducive to informed decisionmaking.

Id. at 448-49. Of course, this narrow definition of materiality is irrelevant if a court is prepared to view rules adopted under a "public interest" standard as unconfined by the parameters of "materiality." See note 556 supra. However, reading NAACP v. FPC, 425 U.S. 662 (1976) (discussed at note 556 supra), and TSC Industries together, most courts are likely to be reluctant to interpret such a public interest standard in a way that risks 
Case law on this issue of "integrity disclosures" is sparse. ${ }^{571}$ Those few judicial decisions that have focused on the materiality of integrity disclosures all have involved self-dealing by management. ${ }^{572}$ As noted earlier, however, much modern corporate misconduct may be intended to benefit, not to injure, the corporation. In any event, even if the courts adopted the Commission's position regarding "integrity disclosures," the approach has a significant conceptual limitation. While the investor might be presumed to have an interest in the integrity of top management, that interest hardly extends to every corporate employee. Yet, the locus of a substantial portion of recent corporate misbehavior appears to be at a considerable organizational distance from top management. In this respect, the efficacy of "sunlight" appears bounded.

The "falsification justification" similarly is of limited potential scope ${ }^{573}$ Much corporate misconduct does not involve distortion of financial records. Even where it does, the financial information disseminated to investors is not necessarily inaccurate or misleading. As one commentator has pointed out, as long as improper payments are "properly categorized as capital expenditures or sales expenses, it is difficult to understand how the payment of bribes causes financial statements to be misleading." ${ }^{574}$ Such procedures

overloading investors. For evidence of a new, more conservative judicial approach, see SEC v. Bausch \& Lomb, Inc., 565 F.2d 8 (2d Cir. 1977).

571 The most frequently cited decision is In re Franchard Corp., 42 S.E.C. 163 (1964), in which the Commission said that the "[e]valuation of the quality of management-to whatever extent it is possible-is an essential ingredient of an informed investment decision." Id. at 170. Citing a Commission decision to establish Commission authority does, however, involve an element of bootstrapping. See also Note, supra note 555, at 1858 (criticizing the foundations of this theory of ethical materiality). Ironically, the author of the Franchard decision, former SEC Chairman Cary, has recently advised the Commission not to "drown shareholders in information about the character of management," suggesting that a line must be drawn between the Franchard fact situation (a prior felony conviction) and that of instances of management misconduct. See Cary, supra note 538, at 2.

572 See SEC v. Kalvex, Inc., [1975-76 Transfer Binder] FEd. SEG. L. REP. (CCH) ף 95,226, at 98,184 (S.D.N.Y. 1975); Chris Craft Indus., Inc. v. Independent Stockholders Comm., 354 F. Supp. 895 (D.C. Del. 1973); Robinson v. Penn Central Co., 336 F. Supp. 655 (E.D. Pa. 1971); Cooke v. Teleprompter Corp., 334 F. Supp. 467 (S.D.N.Y. 197I). But see note 577 infra.

573 The limitations on this justification are, however, of the SEC's own making, because it generally has focused only on accounting controls to the exclusion of other forms of monitoring. That misconduct by subordinate officials escapes detection by their superiors because of inadequate, substandard monitoring controls within the corporation may be material not because of its own intrinsic significance, but as a symptom of that inadequacy. See text accompanying notes 585-88 infra.

574 Mann, supra note 555, at 1667. See also Note, supra note 555, at 1856-57. 
neither overstate profits nor understate taxes. Under generally accepted accounting principles, there is no additional requirement that the income statement shown to investors subdivide selling expenses into two categories: "legal" and "illegal."

The "contingent liability justification" presents probably the most pervasive and meritorious argument for finding corporate misconduct to be material. Some risks of future liability clearly are material to investors. ${ }^{575}$ But once we reduce the issue of corporate misconduct to financial terms, the relative size of the liability unavoidably becomes central to determining materiality. The legal and accounting professions have recently agreed to joint criteria for determining when contingent liabilities must be disclosed. They have decided that disclosure of an unasserted possible claim is required only when (1) it is reasonably probable that the claim will be asserted, (2) there is a reasonable possibility that, if asserted, the outcome will be unfavorable to the corporation, and (3) the liability resulting from the unfavorable outcome would be material under traditional standards to the company's financial condition. ${ }^{576}$ If in a given case the type of questionable conduct in the particular foreign country seldom results in any liability, under this theory of materiality it would seem to follow that disclosure is not required. In sum, these theories do not exhaust the possible scope of "materiality"; ingenious new theories will continue to be advanced, and to a degree, courts may accept them. But this discussion suggests that defendants have a number of plausible responses to these theories that make it unlikely that the scope of the

575 In Heit v. Weitzen, 402 F.2d 909 (2d Cir. 1968), cert. denied, 395 U.S. 903 (1969), the Second Circuit held that failure to disclose a contingent liability resulting from overcharging the federal government under a cost-plus contract could make financial statements materially misleading and thereby violate rule $10 \mathrm{~b}-5$. But apparently at the suggestion of the SEC in an amicus brief, the court carefully avoided the problem of whether corporate misconduct inherently creates an obligation to disclose because of its potential impact on financial statements. See Stevenson, supra note 19, at 70-71.

576 Statement of Financial Accounting Standards No. 5, Accounting for Contingencies, was adopted by the Financial Accounting Standards Board in March, 1975. It is explained in a Statement of Policy adopted by the American Bar Association's Board of Governors on December 8, 1975. See ABA, Statement of Policy Regarding Lawyers Responses to Auditors' Requests for Information, 31 Bus. Law. 1709, 1719-31 (1976). Several commentators have suggested that these standards should be used as the measure of the corporation's obligation to disclose unlawful acts. See Mann, supra note 555, at 1666-67 \& n.14; Sommer, The Disclosure of Management Fraud, 31 Bus. LAw. 1283, 1287 (1976). 
securities laws can be stretched to cover all instances of corporate misconduct. That these responses have not yet been faced by courts is more testimony to the SEC's overwhelming leverage in enforcement litigation than to the merits of the case. Eventually, the child will come forward to announce that he sees revealing holes in the Emperor's new wardrobe. ${ }^{577}$

Beyond the technical issues inherent in defining materiality, a more generalized problem accompanies any attempt to expand the standards for disclosure to include most forms of corporate misconduct. Making corporations liable under an expanded definition of materiality may increase the losses ultimately falling on innocent stockholders or even consumers. To this objection, however, a satisfactory resolution may be in sight: the SEC could minimize such losses from an expanded theory of "ethical materiality" by simultaneously adopting a "contextual" theory of materiality. ${ }^{578}$ The transactional context would determine what information was material. For example, a different standard of materiality would exist for a proxy contest than for an issuance of shares, because each entails substantially different decisions. In a proxy contest, stockholders are making a noninvestment decision about whom to elect as their stewards (and therefore are more interested in integrity), while in an issuance of shares investors confront a pure investment decision.

577 In this light it is noteworthy that courts have rejected with seeming uniformity all recent attempts to impose liability against corporate officials in private actions under the federal securities laws where the alleged misconduct was not coupled with any element of self-dealing. See Falkenberg v. Baldwin, [1977 Current Binder] FED. SEC. L. REP. (CCH) T 96,086 (S.D.N.Y. 1977); Lewis v. Elam, [1977 Current Binder] FEd. SEc. L. REP. (CCH) I 96,013 (S.D.N.Y. 1977); Levy v. Johnson, [1976-1977 Transfer Binder] FEd. SEC. L. REP. (CCH) ๆ 95,899 (S.D.N.Y. 1977); Meer v. United Brands Co., [1976-1977 Transfer Binder] FED. SEC. L. REP. (CCH) \ 95,648 (S.D.N.Y. 1976). While these actions have been rejected on other issues than that of materiality-most notably, the "transaction causation" issue and the question of implied rights of action-they suggest in their uniform result some judicial skepticism of plaintiffs' theories. Where action is alleged by plaintiffs to have been illegal, but the operative facts have been disclosed, most courts have agreed that disclosure is not required of plaintiff's "unproved ... legal theory." Shapiro v. Belmont Indus., Inc., [1977 Current Binder] FED. SEC. L. REP. T 96,206 (E.D. Pa. 1977); see Ash v. LFE Corp., 525 F.2d 215 (3d Cir. 1975). See also SEG v. Bausch \& Lomb, Inc., 565 F.2d 8 (2d Cir. 1977).

578 See Address by Commissioner A.A. Sommer, Jx., The Slippery Slope of Materiality (December 8, 1975) (discussing the "faintly heard suggestion that perhaps standards for determining materiality differ depending upon the context"). 
The practical significance of such a contextual approach would be that courts and the SEC could require the disclosure of information without drawing along the potentially astronomical liabilities that today exist under rule $10 \mathrm{~b}-5$. For example, the legal conclusion that undisclosed information bearing on the integrity of management was relevant to a decision by shareholders asked to approve incentive compensation for management generally would implicate rule $14 a-9,{ }^{579}$ which regulates proxies, but not necessarily rule $10 \mathrm{~b}-5$. By making a distinction between investment decisions (where rule $10 \mathrm{~b}-5$ would apply) and noninvestment decisions (where it would not), courts would be able to make the punishment come closer to fitting the crime. Some indications exist that the SEC is leaning in this direction..$^{580}$

Before one can realistically place primary reliance on the federal securities laws as a remedy for corporate misconduct, a greater hurdle must be overcome: at present only a relatively reduced role exists for private enforcement of disclosure standards with respect to corporate misconduct. Unlike the SEC litigator, who can partly compensate for the logical weaknesses in his theory of materiality by donning the mantle of the white knight fighting corruption, the private litigant seeking damages occupies a less sympathetic position and faces far more serious obstacles in the form of standing and causation requirements. ${ }^{581}$ Since the first cases implying a private right of action under the federal securities laws, reliance upon

57917 C.F.R. $\$ 240.14 a-9$ (1977). The basic prohibitions of the two rules are equivalent. However, rule 14a-9 only applies where there is a "solicitation" of proxies, while rule $10 \mathrm{~b}-5$ requires that there be a purchase or sale of securities. The remedy for a misleading statement in a proxy statement relating to approval of an incentive compensation plan probably would consist of little more than the rescission of such plan, because of the existence of a "transaction causation" requirement. See note 581 infra.

580 See SEC Securities Act Release No. 5627, [1975-1976 Transfer Binder] FED. SEc. L. REP. (CCH) If 80,310, at 85,719-23 (Oct. 14, 1975); SEC Exchange Act Release No. 13,185, [1977 Current Binder] FED. SEc. L. REP. (CCH) If 80,896, at 87,383 (Jan. 19, 1977) (binting that the involvement of corporate officers in questionable payments may be material to shareholders only "in determining whether to give a proxy").

581 A private litigant wishing to sue under rule $10 \mathrm{~b}-5$ because of the failure to disclose improper payments or practices faces two immediate obstacles. First, he must be a purchaser or seller of securities at or about the time of the misleading statement or nondisclosure. Blue Chip Stamps v. Manor Drug Stores, 421 U.S. 723 (1975). Second, he must prove scienter, see Ernst \& Ernst v. Hochfelder, 425 U.S. 185 (1976), which may be difficult where the improper activities were localized at a lower level within the corporation and unknown to senior management. Although there is conflict of authority on the question of scienter, it appears likely that the SEC need meet neither of these requirements in an injunctive 
private attorneys general to supplement public enforcement has been recognized as essential to the full enforcement of the securities laws. ${ }^{582}$ Yet here, it is likely to be the exception, rather than the rule.

In addition to these practical limitations on the ability of the securities laws to remedy corporate misconduct, there may also be a policy reason for not choosing disclosure as the primary means to remedy corporate misgovernance. Disclosure undoubtedly does raise the "embarrassment cost" to the corporation, and so acts as a deterrent. But to complete the syllogism by saying "therefore more disclosure means less misconduct" is to omit a critical step. This article has argued that a principal obstacle to closer monitoring of corporate behavior is the phenomenon of "control loss" that seems to characterize many large decentralized organizations. If centrifugal forces exist within large corporations that often inhibit and sometimes cripple the ability of those at the top to learn of and to deal with problems at lower levels, then the first step towards institutionalizing a stronger corporate superego appears to involve improving the upward flow of information. This means increasing

action (although even it must show a "material" omission or misstatement and a future "propensity" to violate the securities laws in order to justify the issuance of an injunction). Compare SEC v. World Radio Mission, Inc., 544 F.2d 535, 540-41 (1st Cir. 1976), with SEC v. Bausch \& Lomb, Inc., 420 F. Supp. 1226, 1240-41 (S.D.N.Y. 1976), aff'd, 565 F.2d 8 (2d Cir. 1977). The private Jitigant may not sue under section 13 of the Securities Exchange Act of 1934 (which requires the filing of certain periodic and annual reports with the Commission), because an implied private right of action has been held not to exist under this section. See Levy v. Johnson, [1976-1977 .Transfer Binder] FED. SEc. L. REP. (CCH) I 95,899 (S.D.N.Y. 1977); Meer v. United Brands Co., [1976-1977 Transfer Binder] FED. SEC. L. REP. (CCH) I 95,648 (S.D.N.Y. 1976). While a plaintiff who relies upon misleading statements in a document filed pursuant to section 13 may sue under section 18(a) of the Act, he must again meet a purchaser-seller requirement under.section 18, and the defendant may establish a good faith defense.

By suing under section 14 of the Act and rule 14a-9, the private litigant avoids these obstacles but encounters another. At present, a showing of scienter is not required to establish a violation of the proxy rules. Gou'd v. American-Hawaiian S.S. Co., 535 F.2d 761, 777-78 (3d Cir. 1976). But several cases dealing with improper payments have held that the "transaction causation" requirement that exists under section 14 precludes a corporation from suing its directors to recover illegal payments, on the theory that the stockholders would not have reelected the directors had such payments been disclosed, thereby preventing further payments. These courts have taken the narrow view that because the payments were not the subject of the proxy solicitation, "transaction causation" was lacking. See Lewis v. Elam, [1977 Current Binder] FEd. SEc. L. Rap. (CCH) II 96,013, at 91,554-55 (S.D.N.Y. 1977); Levy v. Johnson, [1976-1977 Transfer Binder] FED. SEc. L. REP. (CCH) If 95,899, at 91,324 (S.D.N.Y. 1977).

582 See J.I. Case Co. v. Borak, 377 U.S. 426 (1964). 
the flow to the board, the organ within the corporation most capable of exercising a detached, long-range judgment. But such disclosure to the board will be inhibited if as a necessary corollary it must also make a "confessional" revelation to the world of the embarrassing specifics of corporate misbehavior. Organization theorists agree that a necessary precondition for information sharing within an organization is a reasonable degree of trust and confidence between the informant and the recipient. ${ }^{583}$ Approaches such as the mini-board concept are based on the premise that information flow can be increased best by giving subordinates positive incentives to divulge potentially adverse information and by minimizing negative incentives such as public exposure. Indeed, the SEG's enforcement staff has itself found corporations far more prepared to reveal sensitive information when the disclosure could be exempted from the Freedom of Information Act. ${ }^{84}$ Put simply, information flows best when there is some assurance of privacy.

This is not an argument against disclosure per se. A major distinction exists between "generic" disclosure and "confessional" disclosure. By destroying any degree of privacy, "confessional" disclosure probably creates a disincentive for subordinates to pass sensitive information to the board. Because a corporate official can always rationalize nondisclosure to the board, reliance on a system of compelled public confession may not eradicate corporate misconduct, but only make it less visible and more covert. Since the reduced effectiveness of the board that such an approach risks might exceed any positive gain realized by the creation of an increased deterrent, there is reason for proceeding with caution in this area, particularly if we believe that the board as an internal monitoring apparatus possesses a far greater capability for serving as an effective watchdog than any external agency.

These considerations do not mean that disclosure is an undesirable remedy. Rather, our earlier diagnosis suggests that the focus should shift from a preoccupation with the details of misconduct to a concentration on the process of monitoring itself. A number of

583 See text accompanying notes 165-69 supra.

584 For a review of corporate attempts to obtain such exemptions, see Herlihy \& Levine, supra note 2, at 591-93. Other members of the Enforcement Division staff have confirmed to me that FOIA disclosure is often the major stumbling block in the negotiation of consent decrees, and that sensitive documents are more likely to be given to the staff when they can be confidentially retained within the agency's work papers. 
questions should be asked. What internal controls does the corporation have? Has the corporation rejected other recommended procedures for improved supervision, and, if so, why? How "independent" is the board, and what procedures are used to prepare and alert it? If the outside directors have not been provided with a staff of special counsel or other recommended auxiliary services, why not? ${ }^{585}$ Asking these and other questions might spread the sunlight of disclosure not simply on corporations that already have been caught, but also on those that are insufficiently safeguarded. Such required disclosures need not result in mere boilerplate answers, because empirical research indicates that there are presently wide disparities in the internal information systems that exist within large corporations. ${ }^{586}$ Nor are boards alike in their level of independence.

More importantly, such a new orientation to disclosure would exert a desirable influence on corporate management to adopt recommended monitoring controls and reforms. One precedent provides persuasive evidence of this conclusion. With the adoption of Accounting Series Release No. 165 in 1974, public corporations are now required to disclose the details of any disagreement within a specified period preceding the removal or resignation of the corporation's outside auditors. ${ }^{587}$ This disclosure reform apparently has significantly strengthened the position of the outside auditor and made him more independent. ${ }^{588}$ By analogy, similar disclosures could be required regarding the circumstances surrounding directorial resignations or removals, and the effect might

585 A forthcoming article by Professors Donald Schwartz and Elliott Weiss will attempt to describe in detail the kinds of disclosure that such a reorientation might require. See Weiss \& Schwartz, It's Time for the Board to Come Out of the Closet, Harv. Bus. REv., January-February, 1978, at 18.

586 See Mace, Management Information Systems for Directors, Harv. Bus. Rev., November-December, 1975 , at 14 .

587 See note 190 supra. A.S.R. 165 requires the corporation to explain disagreements (not including those over the accountant's fees) within two years prior to the accountant's removal or resignation that, had the disagreement not been resolved in the accountant's favor, would have resulted in a qualified opinion. The accountant then is required to confirm or to comment upon management's explanation of the disagreement. For useful discussions of A.S.R. 165, see Kay, Disagreements Under Accounting Series Release No. 165, J. Accountancy, October, 1976, at 75; Weiss, Disclosures Surrounding a Change in Auditors: Accounting Series Release 165, CPA J., March, 1975, at 11.

588 For this conclusion and recommendations concerning methods for increasing the accountant's independence, see Nichols \& Price, The Auditor-Firm Conflict: An Analysis Using Concepts of Exchange Theory, 51 Accounting Rev. 335 (1976). 
also be to strengthen the position of the outside director, who is the linchpin of any board-based system of corporate accountability. ${ }^{589}$

Such a system of disclosure focused on the process of monitoring would not have many of the undesirable aspects of "confessional" disclosure. It would not force the board to operate in a fishbowl environment, nor overload investors with an avalanche of information about each incident of questionable corporate conduct, nor subject the corporation and its stockholders to the losses that might result from "confessional" disclosure. Here then, the public interest and the interest of investors may coincide rather than conflict. ${ }^{590}$

It would be a serious mistake, however, to equate the potential role of the federal securities law in the reform of corporate conduct with a disclosure strategy. Other avenues are open to the SEC. In overview, these other basic options, all of which the SEC has recently begun to explore, are threefold. First, the Commission can increase the capability of shareholders to object to questionable practices by expanding the shareholders' right to submit proxy proposals. ${ }^{591}$ Second, it can make the board more independent through devices such as the audit committee. ${ }^{592}$ Third, as we shall see next, it can strengthen the internal monitoring controls of the public corporation. All these approaches shift the focus of ameliorative efforts from substantive reform to basically procedural reform..$^{593}$

589 For a discussion of the possible impact that even a single dedicated maverick director might have, see Staff of the SEC, The financial Collapse of the Penn Central Company, Staff Report of the SEC to the Special Subcomm. on Investigations, House Comm. on Interstate and Foreign Commerce, 92d Cong., 2d Sess. I66-70 (Subcomm. Print 1972) (reviewing the futile attempts by Penn Central director Odell to alert other board members to the symptoms of impending disaster).

590 As noted in note 581 supra, if such disclosure were required exclusively in proxy statements there would be little possibility of damages being assessed against the corporation (unless the adoption of monitoring controls were the subject of the proxy solicitation), because of the "transaction causation" requirement of Lewis $v$. Elam and Levy v. Johnson. Plaintiffs might seek injunctive relief, however, and attorneys" fees could be awarded to provide an incentive without stockholders experiencing a material decline in the value of their securities.

591 Schwartz \& Weiss, An Assessment of the SEC Shareholder Proposal Rule, 65 GEo. L. J. 635 (1977).

592 See text accompanying note 386 supra.

593 Interestingly, Professors Deutsch and LaRue have detected a similar shift to procedural reform in the efforts of federal courts. They feel that the emphasis of the Warren 
The Commission's recently issued proposed rules under section 13(b) of the Securities Exchange Act of 1934 provide a particularly interesting case in point. In Exchange Act Release No. 13,185, the Commission proposed four rules to require most public corporations to maintain accurate books and records and "an adequate system of internal accounting controls designed to provide reasonable assurance that specified objectives are satisfied." 595 Two of the rules specifically proscribe substantive evils that the Commission saw as underlying the improper payments crisis: the falsification of accounting records and the deception of the corporation's independent auditors. But the most intriguing rule from our perspective is proposed rule 13b-2, which pursues the goal of greater corporate accountability through the procedural reform of tighter internal accounting controls. ${ }^{596}$ The rule appears to be the first explicit effort under the federal securities laws to require the corporation to install and maintain monitoring controls-in effect to buy itself a watchdog. Equally important, the Release seems to announce a norm directly addressed to the "control loss problem": "The establishment and maintenance of a system of internal controls is an important management obligation. A fundamental

Court on obtaining desired end results has been replaced by a new judicial self-restraint focusing on procedural improvements. See Deutsch \& LaRue, The Law of Fogel v. Chestnutt: An Historical Analysis, 5 SEc. REg. L.J. 56, 57-58 (1977).

594 [1977 Current Binder] FED. SEc. L. REP. (CCH) đ 80,896 (Jan. 19, 1977).

595 Id. at 87,375 . It seems unlikely that the proposed $13 \mathrm{~b}$ rules will ever be adopted (at least under that section), since legislation amending the Securities Exchange Act of 1934 to prohibit governmental bribes and to require adequate accounting controls was passed late in 1977 , see note 65 supra, thereby superseding these proposed rules. But because the new legislation shares the same preoccupation with accounting controls as did the proposed rules, the issue remains open whether section 13 could support rules directed at other forms of internal controls. As is argued in the text accompanying note 602 infra, the justification advanced to support proposed rule $13 \mathrm{~b}-2$ seems of particular interest, because it is potentially capable of supporting other forms of internal controls.

596 Proposed Rule 13b-2, 42 Fed. Reg. 4,859 (1977) would require that:

[E]very issuer shall devise and maintain an adequate system of internal accounting controls sufficient to provide reasonable assurance that:

(1) Transactions are executed in accordance with management's general or specific authorization;

(2) Transactions are recorded as necessary (i) to permit preparation of financial statements in conformity with generally accepted accounting principles or any other criteria applicable to such statements and (ii) to maintain accountability for assets;

(3) Access to assets is permitted only in accordance with management's authorization;

(4) The recorded accountability for assets is compared with the existing assets at reasonable intervals and appropriate action is taken with respect to any difference. 
aspect of management's stewardship responsibility is to provide shareholders with reasonable assurances that the business is adequately controlled." 597

Although few topics seem less revolutionary than accounting reform, the statement of the norm here is more generalized. Because the Release speaks in terms of assuring shareholders "that the business is adequately controlled," it would seem to justify other forms of internal compliance techniques besides simple accounting controls. The statutory source of authority cited by the Release, section 12 (b) of the 1934 Act, ${ }^{598}$ seems equally capable of fathering a requirement to install nonfinancial internal controls. That section basically requires companies listed on national securities exchanges to file information about certain enumerated topics to the extent that the Commission deems necessary or appropriate in the public interest or for the protection of investors. ${ }^{599}$ To support its claim that the Commission was authorized to adopt rules tightening accounting controls, the Release pointed to those subparagraphs of section $12(\mathrm{~b})(1)$ that specifically refer to financial records. ${ }^{600}$ But other subparagraphs in that same section mandate information regarding "the organization, financial structure, and nature of the business," ${ }^{601}$ as well as "directors" and "officers." ${ }_{002}$ If a reference to accounting records justifies rules ensuring that financial information is reliable and protected by adequate internal controls, it seems equally arguable that references to the

597 [1977 Current Binder] Fed. SEC. L. REP. (CCH) $\mathbb{1} 80,896$, at 87,379 . However, the ABA's Federal Regulation of Securities Committee has suggested that the Commission reconsider its authority to promulgate these proposed rules, particularly rule $13 \mathrm{~b}-2$, after the decision in Santa Fe Industries. See Special Report No. 693, FEd. SEC. L. REP. (CCH), at 9-10 (May 11, 1977).

598 15 U.S.C. $\$ 78 l(\mathrm{~b})(1970)$.

$699 \mathrm{Id}$.

600 See SEC Exchange Act Release No. 13,185, [1977 Current Binder] FED. SEc. L. REP. If 80,896, at 87,378 (Jan. 19, 1977). Securities Exchange Act of 1934, § 12(b)(l)(J), (K), \& (L), 15 U.S.C. $\$ 78 l(\mathrm{~b})(1)(\mathrm{J}),(\mathrm{K})$, \& (L) (1970), refer respectively to balance sheets, profit and loss statements, and "any further financial statements which the Commission may deem necessary or appropriate for the protection of investors."

601 Securities Exchange Act of 1934, $\$ 12(\mathrm{~b})(1)(A), 15$ US.C. $\$ 78 l(b)(1)(A)(1970)$.

602 Several subparagraphs of section $12(\mathrm{~b})(1)$ require disclosure of the identity of certain officers and directors, and information concerning their direct and indirect remuneration. This specific emphasis on remuneration would seem to justify controls designed to prevent misappropriation of slush funds by corporate officials. See id. $\S 12(\mathrm{~b})(\mathrm{I})(\mathrm{D}),(\mathrm{E}),(\mathrm{F})$, \& (G), 15 U.S.C. $\S 78 l(\mathrm{~b})(1)(\mathrm{D})$, (E), (F), \& (G) (1970). 
"organization" and "structure" of the business justify rules requiring adequate controls with respect to these dimensions of the corporation. Thus, carried to its logical extreme, the same reasoning in theory could justify a rule requiring an expanded staff for the board, an auditing apparatus directed at nonfinancial records, or even a mini-board structure. But even if such an end point is never reached, there is an unexplored basis here for inducing monitoring reforms that transcends the Commission's current fixation with accounting controls.

Limiting SEC reform efforts to accounting controls does not make sense from a policy perspective. Accountants have only recently and grudgingly conceded that they have any responsibility for detecting corporate misconduct. They continue to insist (with considerable justification) that they have neither the methodology, the tools, nor the training to uncover most forms of corporate misconduct, including outright frauds. ${ }^{603}$ Nor do most questionable corporate practices affecting the interests of either investors or the public necessarily involve large payments or hidden slush funds. To rely solely on the accountant as the internal Inspector General of the public corporation, when he himself disclaims his capability for such a role, requires a perverse form of tunnel vision.

Some fragmentary signs exist that the Commission will eventually escape its current fascination with accounting controls. The Commission's staff has begun to experiment with another form of internal control: the management audit. A relatively unnoticed aspect of the consent orders negotiated by the Commission's staff in the improper payments cases is a provision requiring the creation of a "special review committee" of the independent members of the corporation's board. These committees typically have been required to investigate the asserted misconduct and to determine in effect if inadequacies existed in the corporation's internal monitoring system. ${ }^{604}$ To the extent that such an approach seeks to catalyze reform (rather than simply legislate corporate morality by consent order), it complements rather than usurps the board's role as the corporate superego.

Originally, the focus of these management audits was directed simply at the payments themselves: in what amount, for what 
purpose, and by whom made? To this degree, they shared the same preoccupation with accounting controls as Release No. 13,185. More recently, however, the scope of such mandated self-studies has moved beyond the area of payments and financial records into the broader topic of the adequacy of management's internal controls in general. The unheralded precedent for this expansion appears to have been the consent order agreed to by Allied Chemical Corporation in March, $1977 .{ }^{605}$ No payments of any nature were involved. Instead, the SEC's complaint charged Allied with discharging a toxic chemical called Kepone into Virginia's James River, and ultimately into the Chesapeake Bay, causing substantial pollution. The SEC in effect asserted that someone within the corporate hierarchy should have been alert to the pollution. The failure to disclose the material financial liabilities resulting from this conduct, the complaint added, violated both the antifraud and periodic reporting provisions of the Securities Exchange Act of 1934. In the settlement decree, without admitting or denying the allegations, Allied represented that its board had begun an "independent investigation of material environmental risk areas and material environmental uncertainties in connection with its business." ${ }^{606}$ However, in contrast to the substantive relief obtained by the Commission in other decrees, Allied agreed only to take such action as the company determined to be "necessary and proper in the light of such investigation" (although it would give the Commission notice of that action) and to "maintain policies, practices and procedures to apprise its management of material environmental risk areas and material environmental uncertainties in con-

605 SEC v. Allied Chem. Corp., Civil Action No. 77-0373 (D.D.C., filed Mar. 4, 1977). The settlement in this case has been widely reported. See Accord by Allied Chemical and SEC Reached in Suit Citing Antifraud Complaint, N.Y. Times, Mar. 5, 1977, at 26, col. 2; Chemical Firm Bows to SEC Over Kepone, Wash. Post, Mar. 5, 1977, at A-11, col. 3. Ironically, the Commission's success in using the securities laws to contest environmental failures of this sort has come home to haunt it. In the second Natural Resources Defense Council decision, Judge Richey cited this proceeding as a basis for finding arbitrary the Commission's earlier refusal to expand its disclosure requirements to compel corporations to provide more data about the environmental impact of their activities. See Natural Resources Defense Council, Inc. v. SEC, [1977 Current Binder] Fed. SEc. L. REP. (CCH) If 96,057, at 91,762 n.12 (D.D.C. 1977). Hoist in effect on its own petard, the Commission has been told that those theories it asserts in its consent orders also must be followed in its rulemaking proceedings.

608 SEC v. Allied Chem. Corp., Civil Action No. 77-0373, at 2 (D.D.C., filed Mar. 4, 1977). 
nection with its business." ${ }^{607}$ In short, the decree did not sacrifice directional discretion. Rather, the internal corporate process for alerting the board to such environmental problems was isolated for study in order to clarify and reform internal lines of authority.

In sum, both proposed rule $13 \mathrm{~b}-2$ and settlements such as the Allied Chemical case suggest that the idea of a body of federal corporate law is not dead. Notwithstanding Santa Fe Industries, the possibility of federal fiduciary standards generally applicable to corporation governance remains alive today, albeit in a prenatal stage of development. After issuing proposed rule 13b-2, the Commission announced the commencement of a broad reexamination of the SEC's rules relating to shareholder democracy and "corporate governance generally." ${ }^{08}$ Thus, while the bloom is clearly off the rose of rule $10 \mathrm{~b}-5$, there are definite signs that the Commission is preparing a counterattack and, under sections 12,13 , and 14 of the Exchange Act, will eventually reassert federal fiduciary principles that were rejected under rule $10 \mathrm{~b}-5$. These sections give the Commission more definite and specific (although limited) grants of authority than did section 10 , and, unlike section 10 , they do not place courts in the awkward position of cantilevering an immense body of common law from the slender foundation of a vague catchall antifraud provision.

To be sure, this forthcoming assertion of implied authority may suffer the same fate at the hands of the Supreme Court as did attempts to expand rule 10b-5. Whether Santa Fe Industries is construed broadly or narrowly, there are arguments that state law "overlaps" and "conflicts" with proposed rule $13 \mathrm{~b}-2 .{ }^{609}$ In addition, the legislative history of sections 12 and 13 indicates that Congress never intended these sections to authorize substantive

\footnotetext{
607 Id.
}

608 SEC Exchange Act Release No. 13,482, [1977 Current Binder] FED. SEc. L. REP. (CCH) If 81,130 (April 28, 1977). As its jurisdictional basis, this Release relies primarily on section 14(a) of the Securities Exchange Act of 1934, 15 U.S.C. $\$ 78 n$ (a) (1970), whose legislative history does suggest definite congressional interest in preserving the ideal of shareholder democracy. Congress's attention appears to have been focused on this theme by the publication in 1932 of A. BerLe \& G. Means, The Modern Corporation and Private Property (1932). See also Medical Comm. for Human Rights v. SEC, 432 F.2d 659, 676-78, 680-81 (D.C. Cir. 1970), vacated as moot, 404 U.S. 403 (1972). Release 13,482 thus probably rested on stronger legislative authority than did Release 13,185.

609 See note 560 supra. In light of Sante Fe Industries, an ABA Committee has urged the Commission to reconsider the proposed rule's scope. See note 597 supra. 
regulation of corporate conduct. ${ }^{610}$ But when predicting the likely judicial response to such an SEC assertion of authority, these factors potentially are outweighed by the absence of an implied private right of action under section 13.611 Thus, the "open floodgate" theme that appears to have motivated the Supreme Court's recent decisions cutting back on rule 10b-5 would not apply here.

What would be the shape of this new federal law of fiduciary duty? Potentially, it could revive on the federal level the oldest and most neglected of fiduciary duties: the duty of due care. Certainly proposed rule 13b-2 and the New York Stock Exchange's audit committee requirement point in that direction. Two examples of how such a federal duty of due care could develop are illustrative.

First, if rule 13b-2 were adopted in its present form and a corporate management's failure to establish adequate internal accounting controls proximately caused losses through defalcations that otherwise should have been detected, those corporate officials responsible should be liable to their corporation under federal law. Although the private litigant would lack standing to enforce the rule, the SEC could require restitution to the corporation as an ancillary equitable remedy. ${ }^{612}$

610 The Senate version of the Securities Exchange Act of 1934 contained a subparagraph (d) to what is today section 12 of that Act. The subparagraph provided that "nothing in this title shall be construed as authorizing the Commission to interfere with the management of the affairs of an issuer." The conference committee, however, deleted this provision. The House Conference Report explained: "This provision is omitted from the substitute as unnecessary, since it is not believed that the bill is open to misconstruction in this respect." H. R. REP. No. 1838, 73d Cong., 2d Sess. 35 (1934), reprinted in 5 J. Ellenberger \& E. Mahar, Legislative History of the Securities Act of 1933 and SECURITIES EXCHANGE ACr of 1934, Item 20 (1973). Given this agreement by both houses that the informational requirements of section 12 were not intended to authorize substantive regulation of corporate conduct, rule 13b-2's affirmative obligation to maintain internal controls appears to lie at the edge of the Commission's authority.

611 See Levy v. Johnson, [1976-1977 Transfer Binder] FED. SEc. L. REP. (CCH) T 95,899 (S.D.N.Y. 1977); Meer v. United Brands Co., [1976-1977 Transfer Binder] FED. SEC. L. REP. (CCH) II 95,648 (S.D.N.Y. 1976).

612 See SEC v. Texas Gulf Sulphur Co., 446 F.2d 1301, 1308 (2d Cir.) ("[T]he SEC may seek other than injunctive relief in order to effectuate the purposes of the Act, so long as such relief is remedial and is not a penalty assessment." (emphasis added)), cert. denied, 404 U.S. 1005 (1971). For recent cases requiring restitution, see Mathews, Recent Trends in SEC Requested Ancillary Relief in SEC Level Injunction Actions, 31 Bus. LAw. 1323, 1333-34, 1338 (1976). However, the statement in Texas Gulf Sulphur that a penalty assessment may not be imposed could well protect corporate officers from a requirement that they reimburse the corporation for illegal payments that benefited the corporation. 
Second, assume that a corporation listed on the New York Stock Exchange seeks to comply only minimally with that exchange's audit committee rule. A pro forma committee is established but seldom meets, and top management filters the flow of information from the accountants to the committee. If such sham compliance violates the rule, then there should be civil liability, enforceable by private litigants against management to the extent that losses can be said to have proximately resulted because they otherwise would have been detected. Under present law, a private cause of action for violation of this stock exchange rule might even be implied, because the rule seems to be a "substitute" for direct federal regulation, or the rule might simply be cited to support an "evidence of negligence" approach. ${ }^{613}$ Since the SEC virtually thrust the audit committee rule upon the New York Stock Exchange, it cannot be

613 The leading decision on implied private rights of action for violation of stock exchange rules remains Colonial Realty Corp. v. Bache \& Co., 358 F.2d 178, 182 (2d Cir.), cert. denied, 385 U.S. 817 (1966), in which Judge Friendly announced what now is described as the "substitution" test. Under that test, a private right of action could be implied when the Exchange rule alleged to have been violated served as a "substitute" for regulation by the SEC, and particularly where it imposed an obligation or duty unknown to the common law. The SEC involvement in persuading the New York Stock Exchange to adopt the audit committee rule, see note 386 supra, certainly lends credence to the argument that the rule is a substitute for direct federal regulation. In addition, such a requirement is unquestionably unknown to the common law. In Cort v. Ash, 422 U.S. 66 (1975), the Supreme Court established standards for implying private rights of action that, in the view of one recent federal decision, accord with Judge Friendly's analysis in Colonial Realty. See Zagari v. Dean Witter \& Co., [1976-1977 Transfer Binder] FED. SEC. L. Rep. (CCH) If 95,777, at 90,809 (N.D. Cal. 1976).

This analysis, however, is subject to several qualifications. First, such a private right of action, though seemingly authorized by Colonial Realty, could be viewed as violating the prohibition in Santa Fe Industries against "federalizing" state corporate law standards in the absence of an express congressional intent to do so. See notes 558-60 supra and accompanying text. Second, the defendants whom we would seek to hold accountable (namely, senior management, since to hold the corporation liable would only double the loss it had already suffered because of the rule's violation) are not technically subject to the audit committee rule, which applies to corporations rather than to individuals. Although it would be possible to argue that such officers are liable as aiders and abettors of a securities law violation, the simplest answer to these problems is to read the rule as a self-regulatory standard which defines and gives specific content in this context to the general standard of care expected of a fiduciary. Thus, it could be enforced by a state court without regard to problems of federal jurisdiction or implied private rights. See note 391 supra. One case has followed such an approach. In Mercury Inv. Co. v. A.G. Edwards \& Sons, 295 F. Supp. 1160 (S.D. Tex. 1969), the court first found that the NASD's "suitability" rule did not give rise to an implied cause of action, but then found with respect to the pendent claims of common-law negligence that violations of a selfregulatory rule "would be admissible as evidence of negligence . . . " Id. at 1163. 
distinguished away as a private agreement among merchants that creates no protected class. The dust has not yet settled on Santa Fe Industries, but these examples suggest that any report of the death of federal corporation law or federal fiduciary standards would be a highly premature obituary.

\section{Conclusion}

Even the patient reader has his limits, so no attempt will be made here to summarize in detail what has gone before. Rather, it seems wiser to recall our purposes. Part I attempted a critique of the organizational deficiencies that underlie modern corporate misconduct. The central tenet of our diagnosis was that the modern corporation is characterized by inadequate information flow and a decentralization of authority, which renders the board of directors ineffective as a corporate superego. This finding supplied the prism through which Part II analyzed the common law. Without restating the specific suggestions made therein, it seems fair to characterize them generally as procedural reforms that seek to install internal self-corrective mechanisms within the corporation. Twin goals are central to such a strategy: (1) increasing the information flow within the firm so that monitoring stations can operate, and (2) raising the "independence" level of the board so that it can both perform its monitoring responsibilities and transcend the tunnel vision of "group think." One reform without the other is of little value, because the effectiveness of the corporate conscience is constrained by its informational inputs, and knowledge without a breadth of vision yields scant returns.

This strategy can be described as an "organizational-adjustment" in that its primary goal is neither to punish the individual wrongdoer nor to raise the economic disincentives to the corporation. ${ }^{614}$ Rather, its focus is on improving the quality of decisionmaking by institutionalizing a more reflective and capable corporate superego. This emphasis on procedural over substantive reform will not satisfy everyone. In particular, the preference for positive over

614 I borrow the term "organizational-adjustment" from Professor Stone. For his distinction of such a strategy from strategies aimed either at the corporation or its employees, see Stone, Controlling Corporate Misconduct, Pub. INTERest, Summer 1977, at 55, 64-65. As he points out, the fine charged a corporation is frequently de minimis when compared with the expected profit, and prosecution of culpable employees is both rare and possibly worth the risk to the dedicated careerist. Id. 
negative incentives and for reliance on the board and internal monitoring rather than on the individual shareholder and mandatory public disclosure as the chief catalysts for change will displease many. Opponents will argue that such reforms are piecemeal and conservative, that the problem of corporate misconduct is sufficiently serious to justify bolder approaches and pioneering activism by courts and agencies (even if the price of disregarding jurisdictional lines is the gradual and unplanned evolution of the SEC into a Federal Corporations Commission desired by few).

The traditional answer to such arguments for urgent and radical change is to suggest that they be directed to the legislature. And legislative action does seem desirable. For example, whether in the form of federal minimum standards, federal chartering, or an amendment to the Securities Exchange Act of 1934, legislative action requiring public corporations to install adequate internal compliance monitoring systems reporting directly to independent boards would vastly outperform further attempts to expand the already inflated definition of materiality.

But the better answer to those who argue for a more radical intrusion upon the corporation's autonomy lies in focusing on the multiple levers available for reform. Other levers, such as the criminal law and the law of torts, are better suited to supply the necessary general deterrence. The levers that touch upon the internal affairs of the corporation, however, seem uniquely capable of achieving something more subtle and sophisticated: the activation of an internal self-corrective system. To use these levers as a club to achieve deterrence by maximizing their in terrorem effect is to ignore that the epee has its functions that the bludgeon cannat perform.

Finally, it seems important to return in closing to two earlier targets: "fiduciary ideology" and "therapeutic disclosure." This article has been skeptical of the continued relevance to the modern public corporation of the ancient body of law governing trusts and agency. The lawyer's persistent affection for these concepts understandably is motivated by the conceptual handhold they give him. Characterizing corporate officials as fiduciaries confers jurisdiction. But a distinction must be recognized between using fiduciary concepts as a means of acquiring jurisdiction and as a mode of analysis. Once past the threshold stage, courts would be better guided not 
by "the punctilio of an honor the most sensitive," but by the businessman's maxim that "structure must follow strategy."

To question in addition the idea of using disclosure as a deterrent may seem to some conclusive evidence of a meanspirited and cynical perspective. Clearly, such skepticism goes against the grain at a time when Justice Brandeis's aphorism that " [s] unlight is . . the best of disinfectants" ${ }^{15}$ is rapidly evolving from the status of a perceptive legal apercu to that of an iron law. Yet, before this enshrinement is completed, it is worth noting that even outside the context of organization theory, there are other heretics who today also are beginning to question whether a prescription of disclosure and more disclosure as a remedy for misconduct is an answer or simply a self-fulfilling prophecy. ${ }^{.16}$ What has been suggested herein is that we consider more carefully who the appropriate audience is for various types of disclosures. Particularly where disclosure to the world will ripen contingent liabilities into actual losses, the appropriate audience for mandatory disclosure might in turn better be the board as the corporation's monitoring organ. Under

615 L. Brandeis, Other People's" Mfoney 92 (1932).

616 Harvard sociologist Nathan Glazer has raised the theme that disclosure may do more than simply disinfect, but may overprotect and distort by magnifying dangers that are not truly threatening: "The laws of protection ... draw attention to an issue and then extend it." See The Chilling Impact of Litigation, Bus. WEEK, June 6, 1977, at 61, 64. A disclosure system then may have a built-in tendency toward self-perpetuation.

One experienced corporate observer has applied this theme specifically to the corporate context at a recent American Assembly conference on business ethics. A basic circularity of reasoning is present, he asserted, "when intellectuals, having given to the puhlic a distorted picture of the ethical situation in business, then urge that business be reformed because the public lacks confidence in business conduct." He then added, "There is no guarantee -or even a probability-that if business conduct quickly improved the public would hear the news for years, if ever. Some scandals will always be available to observers who will not tackle the hard task of communicating business normality." Ways, $A$ Plea for Perspective, in The Ethics of Corporate Conduct 106, 113 (C. Walton ed. 1977) (emphasis in original).

To the journalist, of course, business normality is a dog-bites-man story that has little intrinsic appeal. These arguments do not mean that we should reject disclosure as a remedy, but only reognize that, as with all other cures, it is not a panacea. Its characteristic problems are a tendency to overkill, to taint all corporations through a guilt by association process, and to be unable to make relevant distinctions-either because of the limited attention span of the public or the inadequate knowledge of the journalist. In contrast, the arguments for giving a relative priority to an internalized model for corporate reform is that it permits greater flexibility, may elicit more information, certainly can make finer distinctions in an area where broad generalizations seem usually inaccurate, and does not subordinate investors' interests to those of the public at large or involve the same dangers of "agency intrusion." See text accompanying note 538 supra. 
such an approach, the focus of disclosure to investors might better be concentrated not on the details of misconduct, but on the adequacy of that monitoring system.

In place of reliance on fiduciary ideology and a confessional system of disclosure, this article has asserted two general propositions about the proper structure of an effective system of corporate accountability. First, a board-based system should outperform (and is to a degree inconsistent with) a shareholder-based system of corporate accountability. ${ }^{617}$ Second, decentralization-the tactic by which modern corporations have dealt with the problem of informational overload-has equal relevance to any attempt to redesign the corporation's conscience. These assertions are debatable. But they at least attempt to align structure and strategy. Until that is done, our attempts to reform corporate behavior may continue to run afoul of Forrester's Law.

617 Beyond the scope of this article is the recent provocative assertion by Professor Walter Werner that our current lack of a corporate superego is itself a shareholdermandated result, since management is disciplined by the need to maximize share values in an efficient capital market. Werner argues that behavior such as that of Gulf President Dorsey is not a symptom of the breakdown of internal controls, but of shareholder preferences. See Werner, Management, Stock Market and Corporate Reform: Berle and Means Reconsidered, 77 CoLum. L. Rev. 388 (1977). Implicit in this view is an acceptance of a relatively strong version of the efficient capital market hypothesis, with which this article would disagree. The perspective of the economist and that of the organization theorist are necessarily in some degree of conflict, and this article has contented itself with exploring the implication of that latter view. 